Junior Leal do Prado

\title{
INVESTIGAÇÃO BIOMÉTRICA EM IMAGENS DIGITAIS PARA DETECÇÃO DE FACES HUMANAS ATRAVÉS DA PROPORÇÃO DIVINA
}

Dissertação apresentada à Escola de Engenharia de São Carlos da Universidade de São Paulo, como parte dos requisitos para obtenção do título de Mestre em Engenharia Elétrica.

Orientador: Prof. Dr. Adilson Gonzaga

São Carlos

2004 
"... o Deus que vivifica os mortos e chama à existência as cousas que não existem."

Romanos 4:17 - Bíblia Sagrada 


\begin{abstract}
À Deus, aquele que é, que era e que há de vir, o Todo-poderoso.
\end{abstract}

Aos meus pais Jair e Maria, às irmãs Suziléa e Thalita, e à namorada Ariane, com amor... 
Ao Prof. Dr. Adilson Gonzaga, mestre e amigo, pelos ensinamentos e orientações precisas e, principalmente, pela confiança e incentivo para a realização desta pesquisa, minha sincera gratidão.

Ao Prof. Dr. Maurílio Boaventura por fundamentar os meus primeiros passos na área de pesquisa com muita paciência e dedicação, o que possibilitou a busca de novos caminhos, meu sincero reconhecimento.

Aos amigos do Laboratório de Visão de Computacional - LAVI, Anderson e Thiago, pelo aprendizado diário, compartilhar de idéias e bons momentos.

À todos os colegas do Departamento de Engenharia Elétrica da EESC-USP, em especial Clayton, Celso França, Fábio e Marcelo pelo companheirismo.

Aos professores e funcionários do Departamento de Engenharia Elétrica que sempre estiveram dispostos a colaborar e, às secretárias Denise e Marisa pela atenção e 'ajudas burocráticas'.

Ao Conselho Nacional de Desenvolvimento Científico e Tecnológico - CNPq pelo apoio financeiro concedido durante a realização desta pesquisa, sem o qual a mesma não seria possível.

Aos amigos 'mosqueteiros', Cassius e Edward, que com muito bom humor e inteligência estiveram sempre abertos para compartilhar os desafios da vida profissional.

Aos amigos da república, Anselmo e Nivaldo, pelas conversas sempre divertidas durante as madrugadas.

À família Palma que proporcionou agradáveis momentos de conversas e orientações em meio a passeios e viagens nesses últimos anos. 
À minha namorada Ariane, que com carinho dispôs de seu tempo na tarefa paciente de revisar partes importantes deste texto e, especialmente, pela compreensão, companheirismo e amor. À você meus agradecimentos repletos de carinho e amor.

À minha família, que de forma sábia, humilde e amorosa ensinam a vencer em cada momento da vida. E neste momento especial, a minha sincera gratidão pelo apoio constante, pelas orações fortalecedoras e por jamais permitirem que eu desistisse dos meus desejos e sonhos profissionais.

E, principalmente, ao Senhor Deus, o Autor da Vida, que me revestiu de força, perseverança e sabedoria para desenvolver toda esta pesquisa mostrando mais uma vez que para Ele nada é impossível. 
PRADO, J. L. (2004). Investigação Biométrica em Imagens Digitais para Detecção de Faces Humanas através da Proporção Divina. Dissertação (Mestrado) - Escola de Engenharia de São Carlos, Universidade de São Paulo, São Carlos, 2004.

O crescimento da utilização de sistemas de reconhecimento no mundo contemporâneo exige processos de detecção cada vez mais robustos e ágeis. Aplicáveis desde sistemas de teleconferência empresarial até mecanismos de segurança e vigilância, a Detecção e o Reconhecimento de pessoas tornaram-se uma constante. Na tentativa de buscar caminhos alternativos, tanto para os problemas de detecção, quanto para os de reconhecimento, este trabalho propõe a utilização de medidas biométricas, mensuradas em imagens digitalizadas de faces humanas. A partir do estudo de tais medidas, torna-se possível a verificação de proporções existentes na face, especialmente a Proporção Divina, podendo constituir, no futuro, a base para algoritmos de detecção e/ou reconhecimento que usufruam das informações trazidas por tais proporções. Diante de uma reduzida quantidade de publicações no meio científico que utilizam a Proporção Divina como meio de detecção e/ou reconhecimento em processamento de imagens, esta investigação vem contribuir com alguns passos nessa direção.

Palavras-Chave: investigação biométrica, proporção divina, secção áurea, retângulo áureo, detecção de faces, reconhecimento de padrões, processamento de imagens. 
PRADO, J. L. (2004). Biometric Investigation in Digital Images for the Detection of Human Faces by Divine Proportion. M.Sc. Dissertation - Escola de Engenharia de São Carlos, Universidade de São Paulo, São Carlos, 2004.

The increase of recognition systems in the contemporary world has demanded robust and agile detection processes. From teleconference systems to security and monitoring mechanisms, the Detection and Recognition of people have became constantly used and applied. In attempt to search for alternative ways to solve both detection and recognition problems, this work proposes the utilization of biometric measures, taken in digital image of human faces. From the study of such measures, it's possible to verify face proportions, especially the Divine Proportion, which could allows, in the future, to implement the detection and/or recognition algorithms that utilize such proportions. Due to small amount of scientific publications that use the Divine Proportion as a way of detection and/or recognition in image processing, this investigation contributes with some steps in this direction.

Keywords: biometric investigation, divine proportion, golden section, golden rectangle, face detection, pattern recognition, digital image processing. 


\section{Lista de Figuras}

1.1 Resultados obtidos por Rowley et al. (1998) . . . . . . . . . . . . . . 7

1.2 Resultados obtidos por Sung e Poggio (1998) . . . . . . . . . . . . . . 8

1.3 Modelo de Face Genérico baseado na Proporção Áurea . . . . . . . . . . 9

1.4 Resultados obtidos por Wang e Tan (2000) . . . . . . . . . . . . . . . . 11

1.5 Resultados obtidos por Yachida et al. (1999) . . . . . . . . . . . . . . 13

1.6 Resultado da Detecção de Faces em imagens de faces com diferentes escalas e ângulos . . . . . . . . . . . . . . . . . . 14

1.7 Resultado da Detecção de Faces em imagens com diferentes orientações . 14

1.8 Resultados obtidos por Yow e Cipolla (1997) . . . . . . . . . . . . . . . 14

1.9 Visão geral do sistema de Lin e Fan (2001) . . . . . . . . . . . . . 15

1.10 Alguns resultados do sistema proposto por Lin e Fan (2001) . . . . . . 16

1.11 A face está muito escura para ser detectada . . . . . . . . . . . . 16

1.12 Face com oclusão do olho direito pelo cabelo preto . . . . . . . . . . 16

2.1 Estudos de Vitrúvio sobre as Proporções Humanas ～. . . . . . . . . . . . 19

2.2 Retângulo Áureo . . . . . . . . . . . . . . . . . . . . . . . . 20

2.3 Pirâmides de Gizé . . . . . . . . . . . . . . . . . . . . . . 21

2.4 Pirâmide com Razão Áurea . . . . . . . . . . . . . . . . . . . . . . . 21

2.5 O Parthenon . . . . . . . . . . . . . . . . . . . . 21

2.6 Sua fachada é um Retângulo Áureo . . . . . . . . . . . . . . . . . . 21

2.7 Estrela de Cinco Pontas com Proporções Áureas . . . . . . . . . . . . . . 22

2.8 As Proporções da Figura Humana - 1490 . . . . . . . . . . . . . . . 25

2.9 "Livro sobre as Proporções Humanas", Albercht Dürer, desenho de 1521 . 26

2.10 Proporções do Corpo . . . . . . . . . . . . . . . . . . . . . . . 27 
2.11 Segmento Áureo . . . . . . . . . . . . . . . . . 28

2.12 Cartões em Retângulo Áureo . . . . . . . . . . . . . . . . . . . 30

2.13 Cartaz publicitário e Revista em Retângulo Áureo . . . . . . . . . . . 30

2.14 Carros modelados com Proporção Divina . . . . . . . . . . . . . 31

2.15 Retângulo Áureo que expressa uma espiral até o infinito . . . . . . . . . 32

2.16 Mona Lisa . . . . . . . . . . . . . . . . . . . . . . . 32

2.17 Mona Lisa e suas proporções faciais . . . . . . . . . . . . . . 33

2.18 Mona Lisa e suas proporções corporais . . . . . . . . . . . . . . . . 33

2.19 Pinturas de Piet Mondrian . . . . . . . . . . . . . . . . . . 33

2.20 Alguns exemplos de Retângulos Áureos no Parthenon . . . . . . . . . . 34

2.21 Outros exemplos de Proporção Divina no Parthenon . . . . . . . . . . . 34

2.22 A Cúpula de St. Paul e o Castelo de Windsor, Londres . . . . . . . . 35

2.23 Edifício construído com Retângulos Áureos . . . . . . . . . . . . 35

2.24 Progressão do nariz para boca; da boca para os olhos; dos olhos para a

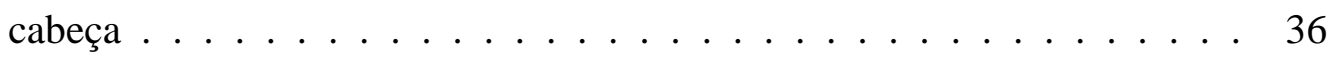

2.25 Proporção Divina no segmento queixo-nariz . . . . . . . . . . . . . 37

2.26 Desenhos Infantis de Faces Humanas . . . . . . . . . . . . . . . 38

2.27 Distância entre o "Branco dos Olhos" . . . . . . . . . . . . . . . 38

2.28 Proporção Divina do Sorriso . . . . . . . . . . . . . . . . . . . . . 39

2.29 Proporção Divina Dente a Dente . . . . . . . . . . . . . . . . . . 41

2.30 Medidas em Razão Áurea . . . . . . . . . . . . . . . . . . . . . . . . 41

2.31 Segmentos Áureos do Dedo Médio da Mão . . . . . . . . . . . . 42

2.32 O Punho Fechado . . . . . . . . . . . . . . . . . . . . . . . . 42

2.33 Segmentos proporcionais em uma face de perfil (Piccin, 1997) . . . . . 43

2.34 Máscara de Beleza do Dr. Marquardt . . . . . . . . . . . . . . . . . . . 44

2.35 Estudos de Ann McNamara e Rachel McDonnell . . . . . . . . . . . 44

2.36 Confirmação das Normas Estéticas no grupo mais bonitos . . . . . . . . 46

2.37 Confirmação das Normas Estéticas no grupo menos bonitos . . . . . . . 46

3.1 Funções de Pertinência para Velocidade . . . . . . . . . . . . . . . 53

3.2 Funções utilizadas para "fuzzificação": (a) função triangular; (b) função trapezoidal; (c) função gaussiana; (d) função sino e (e) função sigmoidal. 56

3.3 Estratégias de "desfuzzificação". Método do máximo critério (MAX). Método da média dos máximos (MOM). Método do centro de máximo $(\mathrm{COA}) . \ldots \ldots \ldots \ldots \ldots \ldots \ldots \ldots$ 
4.1 Etapas do Algoritmo . . . . . . . . . . . . . . . . . . . . . . . . 59

4.2 Etapas do Pré-Processamento . . . . . . . . . . . . . . . . 60

4.3 Imagem Original $\ldots \ldots \ldots \ldots \ldots \ldots \ldots \ldots \ldots \ldots$

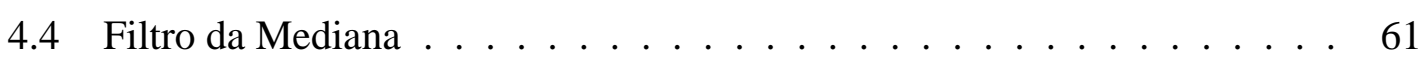

4.5 Detector de Sobel . . . . . . . . . . . . . . . . . . . . . . 61

4.6 Abertura de Área . . . . . . . . . . . . . . . . . . . . . . 61

4.7 Etapas da Extração de Características $\ldots \ldots$. . . . . . . . . . 62

4.8 Regiões da Face . . . . . . . . . . . . . . . . . . . . . . 62

4.9 Ponto Médio da Face . . . . . . . . . . . . . . . . . . . . . 63

4.10 Segmento Áureo . . . . . . . . . . . . . . . . . . . 64

4.11 Segmentos Áureos Horizontais detectados na face . . . . . . . . . . 65

4.12 Segmento Áureo Vertical . . . . . . . . . . . . . . . . . 65

4.13 Segmentos Áureos Verticais detectados na face . . . . . . . . . . 66

4.14 Retângulo Áureo . . . . . . . . . . . . . . . . . . . . . . . 67

4.15 Retângulos Áureos Horizontais detectados na face . . . . . . . . . . 68

4.16 Retângulo Áureo Vertical . . . . . . . . . . . . . . . . . . . 68

4.17 Retângulo Áureo Vertical detectado na face . . . . . . . . . . . . . 69

4.18 Sistema Fuzzy . . . . . . . . . . . . . . . . . . . . . . . . . . . . . 69

4.19 Rede Fuzzy . . . . . . . . . . . . . . . . . . . . . . . 70

4.20 Sistema Fuzzy do Segmento Áureo Horizontal . . . . . . . . . . . . 71

4.21 Funções de Pertinências do Sistema Fuzzy do Segmento Áureo Horizontal 72

4.22 Regras de Inferências para o Segmento Áureo Horizontal . . . . . . . 73

4.23 Sistema Fuzzy do Classificador . . . . . . . . . . . . . . . . . 74

4.24 Funções de Pertinências do Sistema Fuzzy do Classificador . . . . . . . . 74

4.25 Regras de Inferências do Sistema Fuzzy do Classificador . . . . . . . 75

5.1 Número de Segmentos Áureos Horizontais detectados na face . . . . . 77

5.2 Número de Segmentos Áureos Horizontais detectados na face . . . . . 77

5.3 Imagem Original $\ldots \ldots \ldots \ldots \ldots \ldots \ldots$

5.4 Pré-Processamento $\ldots \ldots \ldots \ldots \ldots \ldots \ldots \ldots \ldots \ldots \ldots$

5.5 Imagem Original $\ldots \ldots \ldots \ldots \ldots \ldots$

5.6 Pré-Processamento . . . . . . . . . . . . . . . . . . . . . . . . . 79

5.7 Imagem Original $\ldots \ldots \ldots \ldots \ldots \ldots$

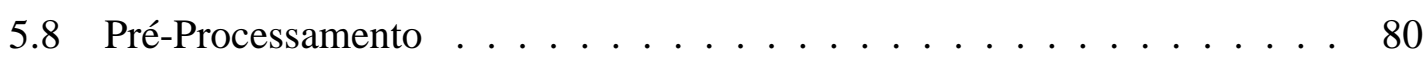

5.9 Imagem Original $\ldots \ldots \ldots \ldots \ldots \ldots$

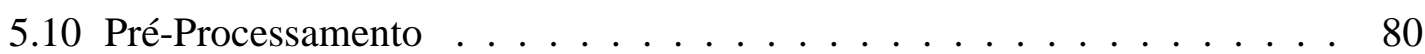


5.11 Imagem Original $\ldots \ldots \ldots \ldots \ldots \ldots$

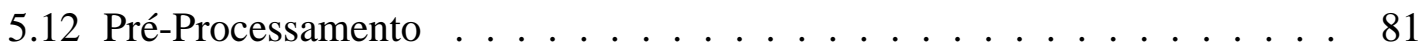

5.13 Imagem Original $\ldots \ldots \ldots \ldots \ldots \ldots \ldots \ldots$

5.14 Pré-Processamento . . . . . . . . . . . . . . . . . . 82

5.15 Imagem Original $\ldots \ldots \ldots \ldots \ldots \ldots$. . . . . . . . . . 82

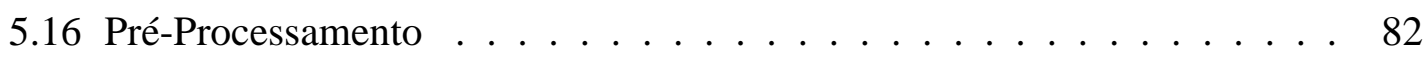

5.17 Imagem Original $\ldots \ldots \ldots \ldots$. . . . . . . . . . . . . 83

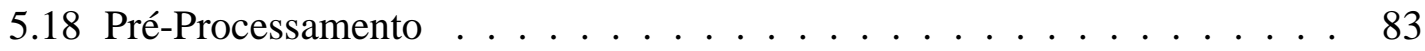

A.1 Medidor de Proporção Divina . . . . . . . . . . . . . . . . . . . . . 94

A.2 Realização da medição . . . . . . . . . . . . . . . . . . . . . . 94

A.3 Medidor sendo utilizado para verificação da Proporção Divina na mariposa 94

A.4 Verificação da Proporção Divina em um Girassol . . . . . . . . . . . . 95

A.5 Verificação da Proporção Divina em Flores _. . . . . . . . . . . . . 95

A.6 Verificação da Proporção Divina em um Ramo . . . . . . . . . . . . . 96

A.7 Verificação da Proporção Divina nas Ondas do Mar e em Peixes . . . . 96

A.8 Verificação da Proporção Divina em Moluscos Marinhos . . . . . . . . 96

A.9 Verificação da Proporção Divina em Insetos … . . . . . . . . . . 97

A.10 Verificação da Proporção Divina nas cores de corpos de diversos animais . 97

A.11 Verificação da Proporção Divina em Face de Tigres . . . . . . . . . . . 98

A.12 Verificação da Proporção Divina no Corpo de Golfinhos e Pingüins . . . . 98

A.13 Verificação da Proporção Divina no Carro . . . . . . . . . . . . . . . 99

A.14 Verificação da Proporção Divina no CD . . . . . . . . . . . . . . . 99

A.15 Verificação da Proporção Divina na Torneira . . . . . . . . . . . . . . 100

A.16 Verificação da Proporção Divina no Violino … . . . . . . . . . . 100

A.17 Verificação da Proporção Divina no Portão da Cidade de Bagdá . . . . . . 101

A.18 Verificação da Proporção Divina na Grande Muralha da China ... . . 101

A.19 Verificação da Proporção Divina na Catedral de Notre Dame . . . . . . 102

B.1 Razão Áurea . . . . . . . . . . . . . . . . . . . . . . . . . . . . . . 103

B.2 Segmento Áureo . . . . . . . . . . . . . . . . . . . . 104

B.3 Construção do retângulo áureo, sendo dado o seu lado menor $b \ldots \ldots$

B.4 Construção do retângulo áureo, sendo dado o seu lado maior $a \ldots \ldots$

B.5 Decágono e o pentagrama, respectivamente . . . . . . . . . . 107

B.6 Triângulo Áureo . . . . . . . . . . . . . . . . . . . . . . . 108

B.7 Gráfico da Seqüência de Fibonacci . . . . . . . . . . . . . . . . 109 
B.8 Espiral Logarítmica . . . . . . . . . . . . . . . . . . . . . . . . 110

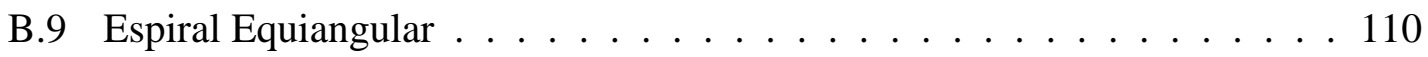

C.1 Número de Segmentos Áureos Horizontais detectados nas faces _ . . . 113

C.2 Número de Segmentos Áureos Horizontais detectados nas faces _ . . . 113

C.3 Número de Segmentos Áureos Horizontais detectados nas faces . . . . 113

C.4 Número de Segmentos Áureos Horizontais detectados nas faces . . . . . 114

C.5 Número de Segmentos Áureos Horizontais detectados nas faces . . . . 114

C.6 Número de Segmentos Áureos Horizontais detectados nas faces . . . . 114

C.7 Número de Segmentos Áureos Horizontais detectados nas faces _ . . . 115

C.8 Número de Segmentos Áureos Horizontais detectados nas faces $\ldots . .115$

C.9 Número de Segmentos Áureos Verticais detectados nas faces . . . . . . 115

C.10 Número de Segmentos Áureos Verticais detectados nas faces . . . . . . 116

C.11 Número de Segmentos Áureos Verticais detectados nas faces . . . . . . 116

C.12 Número de Segmentos Áureos Verticais detectados nas faces . . . . . . 116

C.13 Número de Segmentos Áureos Verticais detectados nas faces . . . . . . 117

C.14 Número de Segmentos Áureos Verticais detectados nas faces . . . . . . 117

C.15 Número de Segmentos Áureos Verticais detectados nas faces . . . . . . 117

C.16 Número de Segmentos Áureos Verticais detectados nas faces . . . . . . 118

C.17 Número de Retângulos Áureos Horizontais detectados nas faces . . . 118

C.18 Número de Retângulos Áureos Horizontais detectados nas faces . . . 119

C.19 Número de Retângulos Áureos Horizontais detectados nas faces . . . 119

C.20 Número de Retângulos Áureos Horizontais detectados nas faces . . . . 119

C.21 Número de Retângulos Áureos Horizontais detectados nas faces ... . 120

C.22 Número de Retângulos Áureos Horizontais detectados nas faces ... . 120

C.23 Número de Retângulos Áureos Horizontais detectados nas faces . . . . 120

C.24 Número de Retângulos Áureos Horizontais detectados nas faces . . . 121

C.25 Número de Retângulos Áureos Verticais detectados nas faces . . . . . . 121

C.26 Número de Retângulos Áureos Verticais detectados nas faces . . . . . . 122

C.27 Número de Retângulos Áureos Verticais detectados nas faces . . . . . . 122

C.28 Número de Retângulos Áureos Verticais detectados nas faces . . . . . . . 122

C.29 Número de Retângulos Áureos Verticais detectados nas faces . . . . . . 123

C.30 Número de Retângulos Áureos Verticais detectados nas faces . . . . . . . 123

C.31 Número de Retângulos Áureos Verticais detectados nas faces . . . . . . . 123

C.32 Número de Retângulos Áureos Verticais detectados nas faces . . . . . . 124 


\section{Lista de Tabelas}

3.1 Conjunto das pessoas de meia idade . . . . . . . . . . . . 51

5.1 Tabela Geral dos Resultados . . . . . . . . . . . . . . . . . 78

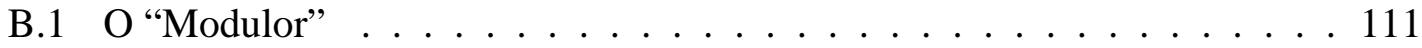


$\begin{array}{ll}\text { Introdução } & 1\end{array}$

1 Métodos de Detecção de Faces Humanas em Imagens Digitais 5

1.1 Introdução . . . . . . . . . . . . . . . . . . . . . 5 5

1.2 Alguns Métodos para Detecção de Faces Humanas . . . . . . . . . . 6

1.2.1 Escala de Cinza . . . . . . . . . . . . . . . 6

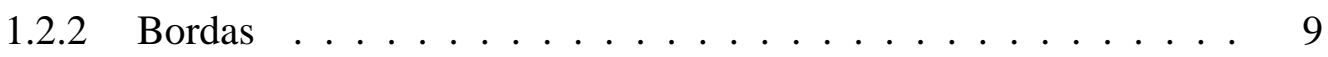

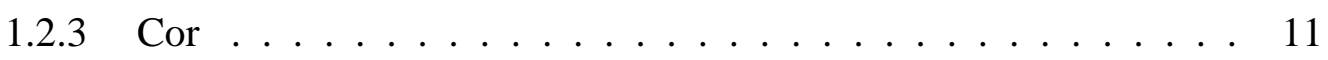

1.2.4 Geometria da Face . . . . . . . . . . . . . 13

1.3 Considerações Finais . . . . . . . . . . . . . . . . . . . 17

2 A Proporção Divina 18

2.1 Introdução . . . . . . . . . . . . . . . . . . . 18

2.2 A História da Proporção Divina . . . . . . . . . . . . . . . . . . . 20

2.2.1 A História do Número de Ouro . . . . . . . . . . . . . . . . . 21

2.3 A Proporção Divina . . . . . . . . . . . . . . . . . . . 27

2.4 A Proporção Divina na Natureza . . . . . . . . . . . . . . . . . . . 29

2.5 A Proporção Divina na Indústria, Comércio e Publicidade . . . . . . . . . 29

2.6 A Proporção Divina na Arte . . . . . . . . . . . . . . . . . 31

2.7 A Proporção Divina na Arquitetura . . . . . . . . . . . . . . . . . 33

2.8 A Proporção Divina no Homem ～. . . . . . . . . . . . . . . . . 36

2.8.1 A Linha dos Lábios . . . . . . . . . . . . . . . . . . . . . . 37

2.8 .2 Desenhos Infantis . . . . . . . . . . . . . . . 38

2.8.3 Proporções entre os Dentes e o Sorriso . . . . . . . . . . . . . 39 
2.8.4 Proporções entre os Olhos e os Dentes . . . . . . . . . . . . . . . 39

2.8.5 Relação Dente a Dente . . . . . . . . . . . . . . . . . . 40

2.8.6 Outras Medidas Interessantes . . . . . . . . . . . 41

2.9 Estudos na Área . . . . . . . . . . . . . . . . . . . . . . . . . 42

3 Conjuntos Fuzzy e Lógica Fuzzy $\quad 47$

3.1 Introdução . . . . . . . . . . . . . . . . . . . . . . . 47

3.2 Histórico . . . . . . . . . . . . . . . . . . . 49

3.3 Conjuntos "Fuzzy" ......................... 51

3.3 .1 Introdução . . . . . . . . . . . . . . 51

3.3 .2 Conceito ....................... 51

3.4 Lógica "Fuzzy" . . . . . . . . . . . . . . . . . . . . . 51

3.4.1 Variáveis Linguísticas . . . . . . . . . . . . . . 52

3.4 .2 Raciocínio "Fuzzy" . . . . . . . . . . . . . . . 53

3.4.3 Modelos "Fuzzy" (Sistema de Inferência "Fuzzy") . . . . . . . . 54

4 Metodologia $\quad \mathbf{5 8}$

4.1 Introdução . . . . . . . . . . . . . . . . . . . 58

4.2 O Algoritmo . . . . . . . . . . . . . . . . . . . . 59

4.2 .1 Aquisição de Imagem . . . . . . . . . . . . . . . 59

4.2 .2 Pré-Processamento . . . . . . . . . . . . . . 60

4.2.3 Extração de Características . . . . . . . . . . . . . . 62

4.2 .4 Classificador . . . . . . . . . . . . . . . . 69

5 Resultados e Conclusões $\quad 76$

5.1 Introdução . . . . . . . . . . . . . . . . . . 76

5.2 Extração das Proporções Áureas . . . . . . . . . . . . . . . . . . 77

5.3 Resultados da Detecção . . . . . . . . . . . . . . . . . . 78

5.4 Conclusões . . . . . . . . . . . . . . . . . 83

5.5 Propostas para Trabalhos Futuros . . . . . . . . . . . . . 84

$\begin{array}{ll}\text { Referências Bibliográficas } & \mathbf{8 6}\end{array}$

A Apêndice - Exemplos de Proporção Divina 93

A.1 O Medidor de Proporção Divina . . . . . . . . . . . . . . . . . 93

A.2 Exemplos de Proporção Divina na Natureza . . . . . . . . . . . . . . . 95

A.3 Exemplos de Proporção Divina na Indústria . . . . . . . . . . . . . . . . 99 
A.4 Exemplos de Proporção Divina na Arquitetura . . . . . . . . . . . . . . . 101

B Apêndice - A Proporção Áurea e Estruturas Adjacentes 103

B.1 Secção Áurea . . . . . . . . . . . . . . . . . . . . . . . . . . . 103

B.2 Segmento Áureo . . . . . . . . . . . . . . . . . . . . . . . 104

B.3 Número de Ouro . . . . . . . . . . . . . . . . . . . . . . . 105

B.4 Retângulo Áureo . . . . . . . . . . . . . . . . . . . . . . . 106

B.5 Pentagrama . . . . . . . . . . . . . . . 107

B.6 Triângulo Áureo . . . . . . . . . . . . . . . . . . . . . . . . . . 107

B.7 Seqüência de Fibonacci . . . . . . . . . . . . . . . . . . . . 108

B.8 Espiral Logarítmica . . . . . . . . . . . . . . . . . . . . 109

B.9 Modulor . . . . . . . . . . . . . . . . . . . 110

C Apêndice - Resultados 112

C.1 Segmento Áureo Horizontal ～. . . . . . . . . . . . . . . . . . . . 112

C.2 Segmento Áureo Vertical . . . . . . . . . . . . . . . . . . . . 115

C.3 Retângulo Áureo Horizontal . . . . . . . . . . . . . . . . . . . . . 118

C.4 Retângulo Áureo Vertical . . . . . . . . . . . . . . . . . . . . . . 121 
Desde os primórdios do processo evolutivo, o ser humano busca desenvolver sua tecnologia de modo a torná-la extensão, ou mesmo substituta, de seu próprio corpo. As idéias de máquinas e seres animados automatizados habitam o imaginário humano há longa data.

Inserido no processo de verossimilhança e aperfeiçoamento da máquina humana, o estudo da visão exerce grande fascínio. Neste ponto, o interesse está não somente na percepção do estímulo luminoso, mas também, no reconhecimento lógico dos objetos circundantes. Muitos são os animais dotados de visão, uns com sistemas mais simples e outros mais sofisticados, uns mais específicos, outros mais gerais. A visão é usada para inúmeras tarefas, muitas delas relacionadas à sobrevivência e perpetuação da espécie. Sistemas de visão de mamíferos superiores, como os primatas, apresentam uma grande complexidade e mecanismos sofisticados de reconhecimento de padrões (MOREIRA, 1999).

Além do interesse pela visão artificial, os processos automatizados de reconhecimento de padrões ganham volume frente à crescente oposição entre a velocidade da informação e a limitação temporal no mundo contemporâneo. Esses processos requerem eficiência, eficácia e agilidade crescentes.

Nesse sentido, as tarefas visuais automatizadas tornam-se excelentes soluções, especialmente pelo suporte conferido pelo avanço da computação e dos sistemas automáticos. As inspeções visuais de linhas de produção, os sistemas de segurança e vigilância, os sistemas de identificação pessoal, os exames clínicos, os empreendimentos em abissais marinhos e planetas desconhecidos, são exemplos nos quais a aplicação da automação visual vem ganhando espaço. 
Dentro desse contexto, o processamento de faces humanas em cenas tem crescido significativamente em importância nos últimos anos. O propósito dos pesquisadores está voltado ao reconhecimento, não só da face como um todo, mas também, de suas características intrínsecas.

Os frutos de pesquisas nessa área do conhecimento são compartilhados pelo campo científico e comercial. Em relação ao primeiro caso, o ensinamento de computadores para analisar faces busca produzir uma melhor interação entre as máquinas e os seres humanos. Sob o aspecto financeiro, a aplicação crescente ocorre em sistemas de segurança e vigilância, motivada pela violência social, tráfico e terrorismo irrefreáveis.

O comércio da violência é pródigo em mostrar aplicações imediatas para as técnicas de reconhecimento facial: vigilância e segurança de casas monetárias e de departamentos; análise de documentos de identificação e passaportes; controle de multidões; procura de suspeitos em cenas; identificação de pessoal em áreas de segurança; perícia técnica e criminal; montagem e/ou reconstrução de fotos; envelhecimento programado (CHELLAPPA et al, 1995).

A pesquisa científica, centrada em semelhantes fins, alicerça-se sobre a expansão dos campos de sistemas computacionais e das ciências médicas. O crescimento paralelo de ambas as áreas facilita o progresso da automação e, conseqüentemente, da inteligência artificial.

O reconhecimento de faces humanas pode ser realizado tanto pela máquina biológica como pela máquina computacional.

Contudo, computadores são projetados para carregar uma informação após a outra, de uma maneira extremamente rápida, enquanto os cérebros humanos trabalham com muitas unidades de informações lentamente. Um computador consegue realizar milhões de operações por segundo, já o cérebro responde apenas em torno de dez operações por segundo, entretanto trabalha em muitas situações ao mesmo tempo. Desse modo, um computador é uma máquina serial de alta velocidade, enquanto o cérebro é uma lenta máquina paralela (GIOVANINI, 1998).

Analisando esta afirmativa, o fato de um computador falhar nas mesmas operações feitas pelo cérebro pode surpreender. Por exemplo, em uma imagem de uma mesa com livros e cadernos, o cérebro humano é capaz de absorver e processar a cena, de forma que perceba a existência de diferentes objetos desconexos e classifique em suas categorias, mesmo que estes modelos nunca houvessem sido observados.

Agora, se essa mesma imagem for processada digitalmente em um poderoso computador, este terá dificuldades em perceber a existência descontínua dos objetos entre si 
e deles com o fundo, ainda mais se as cores, a luminosidade e a orientação não forem favoráveis. Se a percepção é uma difícil tarefa, a classificação destes objetos num grupo torna-se extremamente árdua.

$\mathrm{Na}$ verdade, os dois sistemas desempenham as tarefas que se encaixam a seus respectivos projetos: o computador, por ser uma máquina serial, realiza operações seriais satisfatoriamente (como a multiplicação de números); e o cérebro, por ser uma máquina altamente paralela, realiza operações paralelas (como a visão, por exemplo). Ao contrário do cálculo com números, no qual uma operação depende apenas da operação anterior, a visão depende de numerosos fatores distintos que ocorrem simultaneamente (GIOVANINI, 1998).

O propósito da automação (no caso, aplicada à visão e ao reconhecimento de padrões) é a obtenção dos princípios gerais sobre os quais se alicerçam as soluções do cérebro, para os problemas de natureza paralela e, assim, aplicá-los aos sistemas computacionais. Estudados esses princípios, desenvolvem-se modelos paralelos para a simulação do comportamento cerebral.

Na simulação do comportamento visual humano denominado genericamente por Visão Computacional, o reconhecimento do padrão facial de uma pessoa constitui uma tarefa desafiadora.

Nesse contexto, o processo de ensinamento do reconhecimento é meticuloso e segmentado em etapas bem definidas. Em um reconhecimento preciso, primeiramente, é necessário detectar as faces e, em seguida, segmentá-las na imagem. Os objetos próximos são eliminados, pois podem influenciar a tomada de decisão nas demais etapas do processo, os quais culminam na identificação.

A comunidade científica tem publicado grande número de pesquisas nesta área. A Biometria de Faces Humanas, ou seja, a técnica de medidas de características intrínsecas à face, é atualmente uma das frentes de pesquisas importantes em Visão Computacional.

Biometria não é apenas referente à medida de quantidades biológicas ou de padrões, mas também significa a medida de características individuais, tais como impressões digitais, ou proporções entre características que podem identificar ou autenticar uma pessoa. Assim, a biometria é um "password" que não pode ser esquecido, perdido ou roubado (DAWSON, 2001).

Dessa maneira, o estudo biométrico é de grande importância, aplicando-se desde o processo de detecção (a segmentação da face em uma cena genérica), até o processo de reconhecimento. 
A indexação e a recuperação de imagens contendo atividades humanas; as técnicas de análise de expressões faciais; as atividades computacionais em tempo real, como a visão de robôs; podem usufruir das técnicas biométricas de detecção de faces humanas para obter respostas rápidas e tomar decisões em curto espaço de tempo.

Da mesma forma, os sistemas de segurança e vigilância, a identificação pessoal e a classificação automática de indivíduos também requerem técnicas biométricas que utilizem padrões não duais conferidos a cada ser humano, para o reconhecimento.

Para que se possa apresentar o assunto e discutir a viabilidade da técnica proposta, esta dissertação de Mestrado está dividida em 5 capítulos.

No capítulo 1 são apresentadas algumas técnicas de Processamento de Imagens para detecção de faces humanas em imagens digitais.

O capítulo 2 enfoca a Proporção Divina e sua utilização nas diversas áreas do conhecimento humano, desde a antiguidade.

No capítulo 3 são apresentados os Conjuntos "Fuzzy" e a Lógica "Fuzzy" como ferramenta de avaliação e classificação de um agrupamento de dados ou informações.

No capítulo 4 é apresentada a metodologia desenvolvida no projeto de Mestrado.

O capítulo 5 evidencia os resultados obtidos com esta metodologia empregada, as conclusões e as propostas para trabalhos futuros. 


\section{Métodos de Detecção de Faces Humanas em Imagens Digitais}

\subsection{Introdução}

$\mathrm{Na}$ árdua tarefa de processamento de faces humanas, o problema de detecção de faces é um dos mais importantes a serem solucionados. A detecção de faces merece especial estudo (YANG \& HUANG, 1994), uma vez que é o pré-processamento necessário para as áreas de reconhecimento automático e análise de expressões faciais.

A localização de faces humanas em imagens digitais é uma tarefa importante em diversas aplicações. A indexação e a recuperação de imagens de vídeo contendo atividades humanas requer a detecção automática da localização das faces dentro da cena. Técnicas que reconhecem faces ou analisam expressões faciais também requerem conhecimento sobre a localização delas dentro da imagem. As aplicações em tempo real, tal como a visão de robôs, devido à necessidade de resposta rápida, podem utilizar técnicas de detecção de faces humanas para que se possa tomar decisões em curto espaço de tempo.

A princípio, temos duas principais abordagem para o problema de detecção de faces. $\mathrm{Na}$ primeira, a face é tratada atomicamente e um modelo geral representando os princi- 
pais traços da face é utilizado como aproximação para a face que se deseja localizar. Esse modelo pode ser estático (quando informações são conhecidas de antemão, por exemplo: o tamanho aproximado das faces em relação à imagem total ou o número de faces presentes na cena) ou dinâmico (métodos mais genéricos em que nenhuma informação a respeito da cena é previamente conhecida).

Na segunda abordagem, a face é localizada através de alguns de seus componentes, tais como olhos, boca e nariz. Da mesma forma que na abordagem anterior, a disponibilidade de informações prévias definirá uma estratégia mais específica ou genérica.

Vários fatores tornam a detecção de faces mais complexa, tais como, cabelo na face, maquiagem, barba ou bigode, uso de óculos e chapéus, os quais escondem as características faciais. Outro problema é a escala e a orientação da face na imagem, pois isso dificulta a utilização de "templates" fixos para achar as características. A presença de ruídos e oclusões, são outros tipos de problemas que também ocorrem (SUNG \& POGGIO, 1998).

\subsection{Alguns Métodos para Detecção de Faces Humanas}

Os métodos de detecção de faces humanas utilizam-se de algumas informações. Alguns dos métodos de detecção de faces usam a informação de imagens em nível de cinza (ROWLEY et al.,1998)(SUNG \& POGGIO, 1998). Outros métodos utilizam as informações das bordas contidas em uma imagem (GOVINDARAJU, 1996)(WANG \& TAN, 2000). Um número considerável de métodos usam a informação de cor para detectar faces (DAÍ \& NAKANO, 1996)(CAI \& GOSHTASBY, 1999)(YACHIDA et al., 1999)(KIM et al., 2000). Existem métodos que utilizam a informação da geometria da face para detectar faces (JENG et al., 1998)(YOW \& CIPOLLA, 1997)(LIN \& FAN,2001).

\subsubsection{Escala de Cinza}

Os métodos baseados em escala de cinza usam características pré-definidas da imagem tanto para treinar o sistema como para casar um modelo. Um método desenvolvido por Rowley et al. (1998) examina pequenas janelas da imagem e decide se cada janela contém uma face, usando Redes Neurais Artificiais. Os autores utilizaram um algoritmo de "bootstrap" para o treinamento da rede neural, que adiciona falsas detecções no treina- 
mento, eliminando assim a difícil tarefa manual de selecionar os exemplos de treinamento "não-face". O sistema pode detectar entre 77,9\% e 90,3\% das faces em um conjunto de 130 imagens, com um número aceitável de falsas detecções. Embora, o sistema tenha sido projetado para detectar faces frontais, a rede pode ser treinada para detectar também faces de perfil.

Alguns resultados obtidos pelo método de Rowley et al. (1998) são apresentados na Figura 1.1.

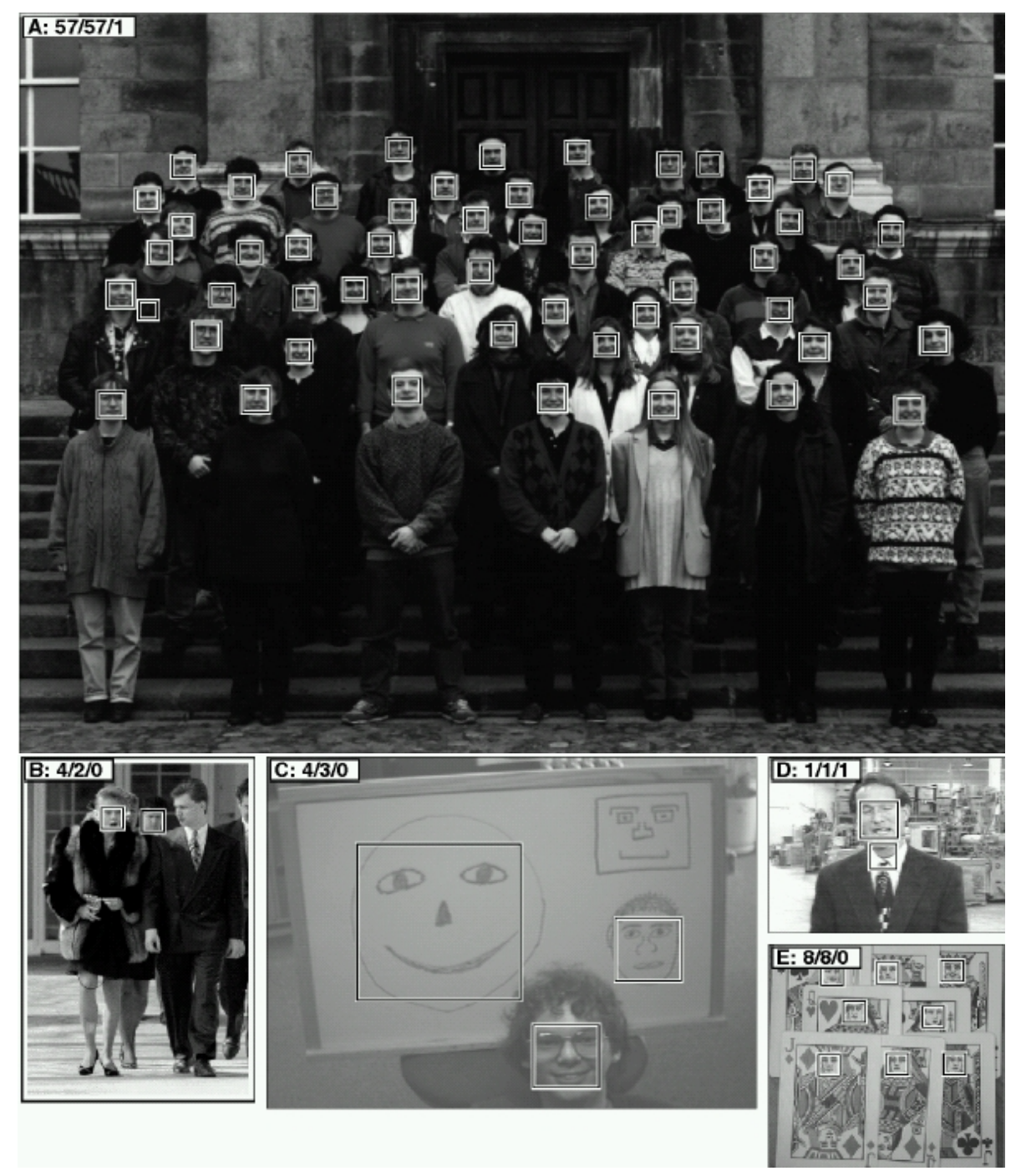

Figura 1.1: Resultados obtidos por Rowley et al. (1998)

Na Figura 1.1, no canto superior esquerdo de cada imagem pode-se observar três números que são: o número de faces contidas na imagem, o número de faces detectadas corretamente e o número de falsas detecções, respectivamente. Na imagem A todas as faces foram detectadas, mas o sistema apresentou uma falsa detecção. Na imagem B as faces não foram detectadas devido à oclusão em uma face e em outra um grande ângulo da 
face em relação à imagem frontal. Em $\mathrm{C}$ o desenho no canto superior direito não foi detectado pelas redes neurais. Na imagem $\mathrm{D}$ a face foi detectada, mas o método apresentou uma falsa detecção na região do pescoço. Embora, o sistema tenha sido treinado somente em faces reais, alguns desenhos de faces são detectados na imagem $\mathrm{C}$ e na imagem $\mathrm{E}$.

Sung \& Poggio (1998) apresentaram uma abordagem para o problema de detecção de faces humanas frontais em cenas complexas, através do aprendizado baseado em modelo. Em cada posição da imagem, um vetor de características é computado entre o modelo local da imagem e o modelo de distribuição. Um classificador treinado determina, baseado nas medidas do vetor de características, se existe ou não uma face humana na posição atual da imagem. Os autores testaram este sistema em duas bases de dados, onde computaram o número de detecções corretas e os falsos alarmes. A primeira base de dados consistindo de 301 imagens frontais e quase frontais de 71 pessoas diferentes. A segunda base de dados contendo 23 imagens com um total de 149 modelos de faces. Para a primeira base de dados o sistema encontrou 96,3\% de todos os modelos de faces e retornou três falsas detecções, utilizando neste teste uma rede neural MLP ("Multi Layer Perceptron") como classificador. Na segunda base de dados o sistema conseguiu uma taxa de 79,9\% de detecções e cinco falsos positivo, utilizando a mesma rede neural MLP.

Na figura 1.2, são mostrados alguns resultados obtidos com o sistema de Sung \& Poggio (1998).
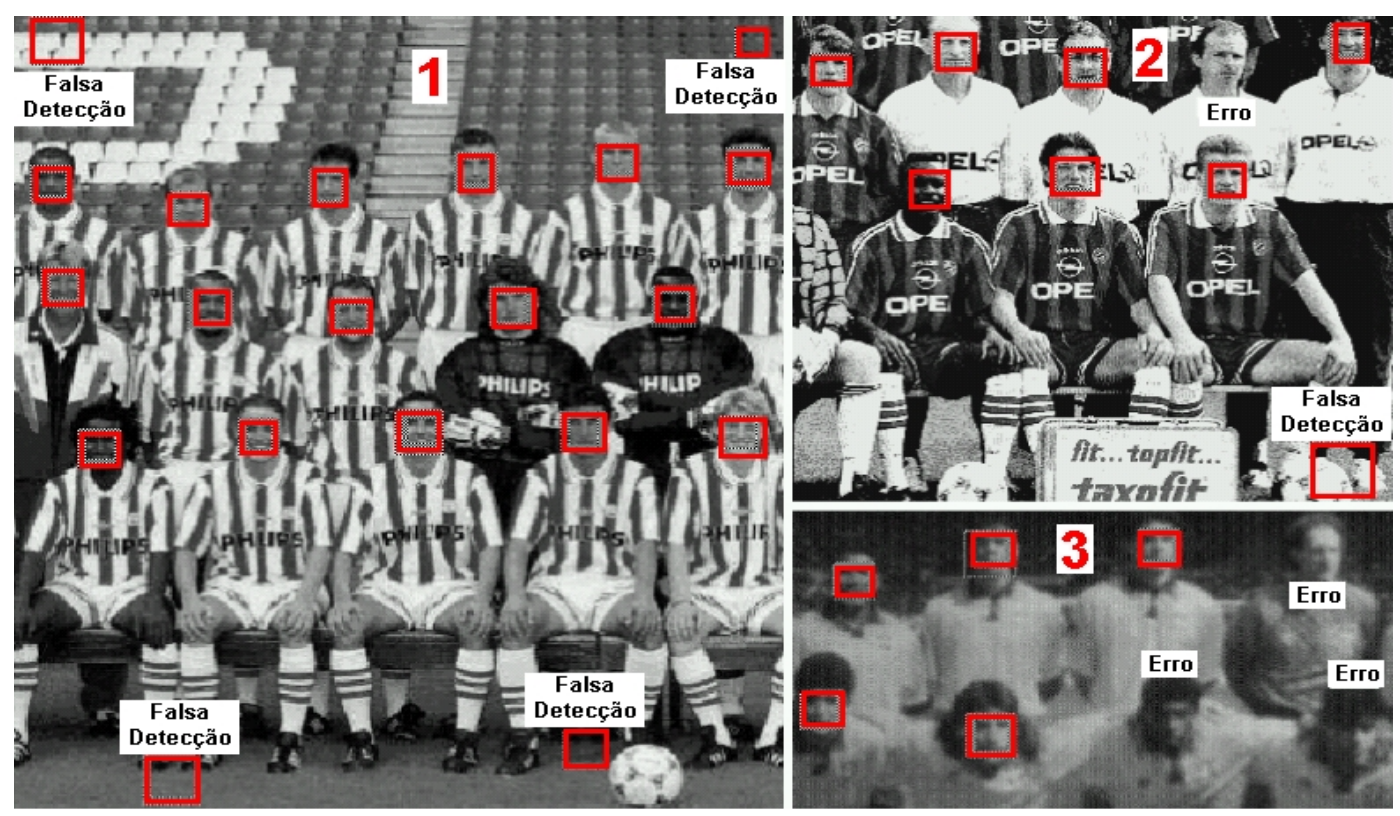

Figura 1.2: Resultados obtidos por Sung e Poggio (1998) 
Na figura 1.2, pode-se visualizar algumas imagens utilizadas no teste do sistema de Sung \& Poggio (1998). Na imagem 1, o sistema detectou todas as faces com quatro falsas detecções. Na imagem 2, o sistema errou na detecção de uma face e as demais faces foram corretamente localizadas, com uma falsa detecção. Na imagem 3, ocorreram três erros devido a sombra de iluminação.

\subsubsection{Bordas}

Para detectar faces humanas utilizando o método de detecção de bordas, deve-se primeiramente classificar estas bordas e, a seguir, relacioná-las com um modelo de face para verificar as corretas detecções (HJELMAS, 2001). Govindaraju (1996) realizou esta classificação de bordas em relação ao lado esquerdo (E), linha do cabelo (C) e lado direto (D) de uma face frontal e, a seguir, relacionou estas bordas com um modelo de face que utiliza a proporção áurea para obter uma face ideal. Este modelo de face genérico (Figura 1.3) foi definido para a fase de geração de hipóteses em termos das características faciais baseado nas bordas de uma face frontal.

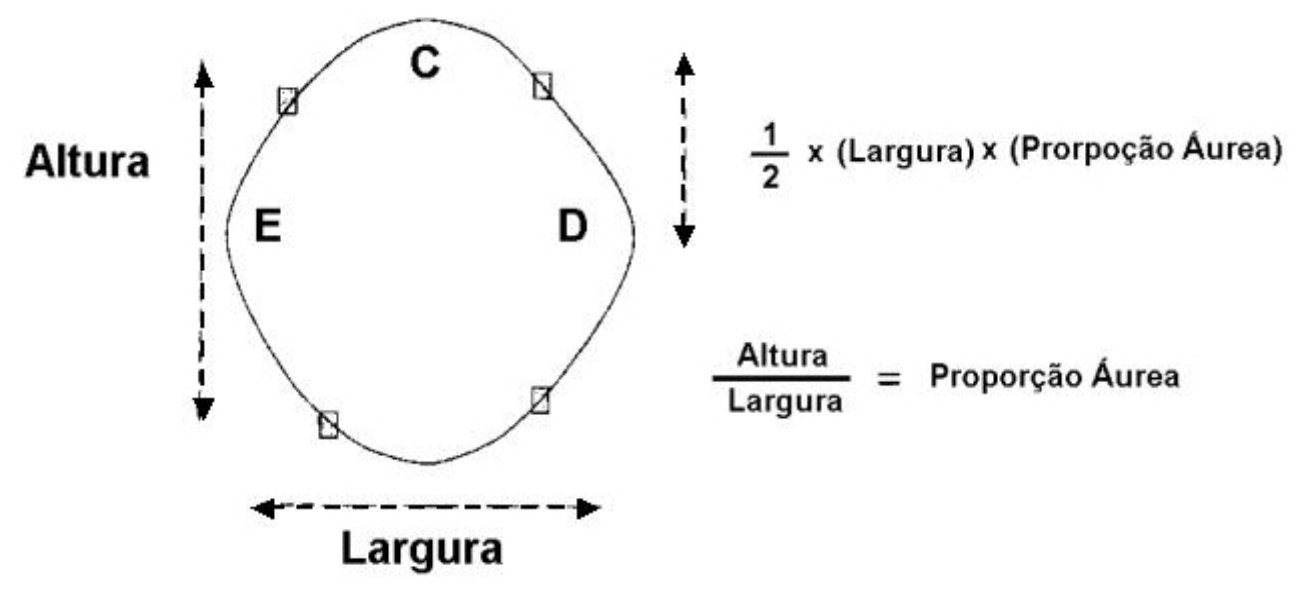

Figura 1.3: Modelo de Face Genérico baseado na Proporção Áurea

As medidas relativa das características faciais foram determinadas baseadas na literatura antropométrica que recomenda utilizar a proporção áurea ${ }^{1}$ para obter uma face ideal (FARKAS \& MUNRO apud GOVINDARAJU, 1996). Definindo as medidas relativas das características faciais em termos de uma proporção ao invés de medidas absolutas assegura-se uma escala independente.

\footnotetext{
${ }^{1}$ Maiores informações sobre a Proporção Áurea estão na seção 2.3 do capítulo 2 e no Apêndice B.
} 
A proporção dos pares de características faciais que formam uma borda é comparada com a proporção áurea e um custo é atribuído para a borda. O custo é a distância entre a figura hipotética da face na imagem para a figura de uma face ideal como descrita pelo modelo.

A extração de características de Govindaraju (1996) possui 7 passos, os quais são descritos a seguir.

1. Detecção de Borda: na imagem as bordas são detectadas por uma convolução da imagem com o operador de bordas de Marr-Hildreth com tamanho de máscara $31 \times 31(\sigma=5)$ seguido por um "zero-crossing”.

2. "Thinning": utilizando um algoritmo de Pavlidis, que faz um identificação de todos os pixels que são essenciais para preservar a conectividade dos contornos na imagem. Os pixels que não são essenciais são apagados, pois os mesmos não pertencem à estrutura do contorno.

3. Remoção de ramificação: em um contorno com ramificações, cada ramificação conectada é reduzida para seu ramo central, visando a preservação da suavidade de um contorno.

4. Filtragem: os contornos com propriedades de não-face são removidos. Por exemplo, contornos perfeitamente retos, contornos com buracos, etc.

5. Ligação de contornos: contornos com extremidades muito próximas, são candidatos para serem ligados juntos. O algoritmo de ligação é baseado na proximidade, direção e tamanho dos contornos.

6. Detecção de extremidade: utilizando os métodos de Medioni \& Yasumoto (1987) e de Beus \& Tiu (1987) a extremidade dos contornos são detectadas.

7. Classificação: os contornos finais são classificados como pertencentes ao lado esquerdo, linha do cabelo ou lado direto de uma face, observando suas formas e direção de concavidade.

Os contornos classificados são combinados para formar uma possível face candidata baseado em uma função que utiliza a proporção áurea. Em um teste realizado com um conjunto de 60 imagens de fundo complexo contendo 90 faces, o sistema detectou corretamente $76 \%$ das faces com uma média de duas falsas detecções por imagem. Neste sistema, a maior taxa de erros encontrada está, primeiramente, na ligação dos contornos 
fragmentados (passo 5) onde ocorrem ligações incorretas e, posteriormente, na classificação dos contornos (passo 7) onde as características faciais são agrupadas de maneira inaceitável.

Wang \& Tan (2000) desenvolveram um método baseado na informação do formato da face. A imagem de entrada, primeiramente, é realçada por meio de uma equalização de histograma, em seguida é realizada uma detecção de borda utilizando o filtro da mediana. As bordas extraídas são ligadas usando um método baseado em uma função de energia. O contorno da face é finalmente extraído utilizando a informação da direção de ligação das bordas. A taxa de corretas detecções deste método é de $84,56 \%$ e uma taxa de falsas detecções de $3,47 \%$. Os resultados imprecisos são causados principalmente pelas faces inclinadas $\left(22,5^{\circ}\right)$. A base de dados utilizada possui 144 faces perpendiculares e 288 inclinadas, o que contribui para uma elevada taxa de imprecisão. Este método pode ser muito eficiente para imagens com fundo simples. A Figura 1.4 mostra alguns resultados deste sistema.
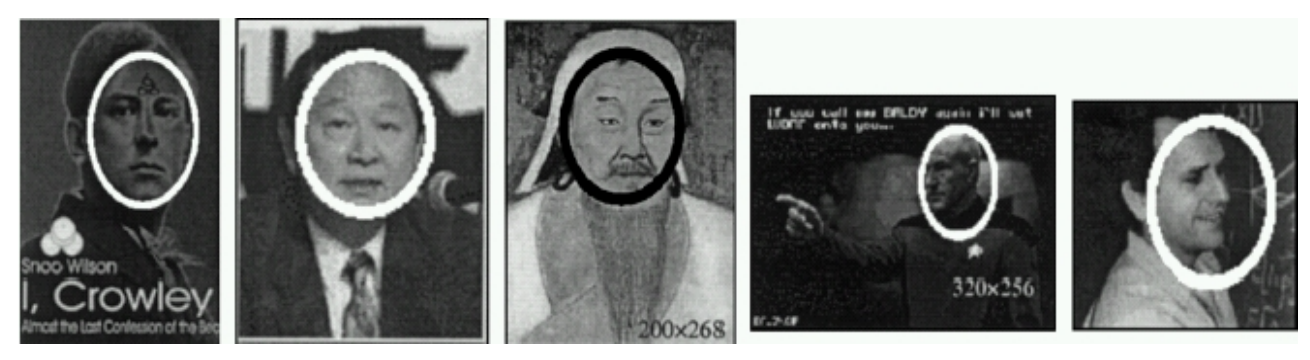

Figura 1.4: Resultados obtidos por Wang e Tan (2000)

\subsubsection{Cor}

Um considerável número de técnicas utilizam a informação de cor para detectar faces. Essas técnicas primeiro selecionam as regiões da imagem mais prováveis de serem faces e então detectam as faces nas regiões selecionadas usando padrões faciais. Daí \& Nakano (1996) isolaram a região próxima ao laranja no espaço colorimétrico YIQ, como região semelhante à pele humana e eliminaram as regiões remanescentes. A partir daí empregaram características de textura em imagens em nível de cinza para identificar faces nas regiões da pele. No primeiro teste foram selecionadas, aleatoriamente, 10 pessoas diferentes em um banco de dados de faces e foram realizados um conjunto de cinco ou seis testes por pessoa. Neste teste estavam incluídas faces com rotação, inclinação e expressão. 
A taxa de corretas detecções verificadas neste teste foi de $98 \%$. Contudo, este sistema não pode detectar faces com oclusão parcial, faces usando óculos e faces de perfil.

O algoritmo proposto por Cai \& Goshtasby (1999) realiza a detecção das possíveis faces através de computações realizadas no espaço colorimétrico CIE Lab. Transformam cada cor em seu nível de cinza correspondente e utilizam essa informação como uma função de distribuição de probabilidade para determinar as regiões que podem ser faces humanas em uma imagem. A partir daí, empregam "template matching" para identificação final. Em testes realizados pelos autores, quando um "threshold" de 0,5 foi utilizado, $13 \%$ das faces foram perdidas, enquanto $8,7 \%$ das faces foram detectadas erradas.

Yachida et al. (1999) descreveram um método para detectar faces em imagens coloridas baseado na teoria "fuzzy". Esse método trabalha com dois modelos "fuzzy", um para descrever a cor da pele e outro para descrever a cor do cabelo, utilizando-se de um espaço de cores percentuais para aumentar a precisão do método. Foi criado um modelo para extrair as regiões de cor da pele e um outro para extrair as regiões de cor do cabelo. Comparando este dois modelos com um modelo de "head-shape", utilizando o método de casamento de modelo baseado na teoria "fuzzy", pode-se detectar as faces candidatas. No teste realizado com esse método utilizou-se um banco de dados com 223 faces, onde 186 eram faces asiáticas e as demais faces eram caucasianas. O tamanho das faces variam de 20x24 pixels até 200x240 pixels. O índice de acerto nas detecções foi de $97 \%$ em imagens com tamanho de face maior que 50x60 pixels. As falhas desse método ocorrem devido a alguns fatores, tais como: variação de iluminação, oclusão facial, faces adjacentes (Se duas ou mais faces estiverem muito próximas, os modelos que descrevem a cor da pele e do cabelo podem ser fundidos juntos; resultando em uma forma bem diferente de uma única face.) e estilo de cabelo (Por exemplo, faces com um penteado especial de cabelo, faces de pessoas carecas e faces com pessoas usando chapéus.). Alguns resultados obtidos pelo método de Yachida et al. (1999) são apresentados na Figura 1.5.

Kim et al. (2000) apresentaram um método de detecção de faces humanas baseado em um objeto. Esse método possui dois passos: segmentação da região e detecção da região facial. No primeiro passo, a imagem de entrada é segmentada por um algoritmo genético dentro de algumas regiões iniciais. A seguir, as regiões são unidas de acordo com uma similaridade espacial pois as regiões de formação de um objeto compartilham de algumas características espaciais comuns. No segundo passo, as regiões faciais são identificadas a partir dos resultados do primeiro passo utilizando um modelo de cor de pele. A taxa de sucesso nas detecções de faces desse método é de $82 \%$ e a taxa de falsas detecções é de $17 \%$. Essa considerável taxa de falsas detecções é devido a erros que ocorrem na segmentação da imagem. 


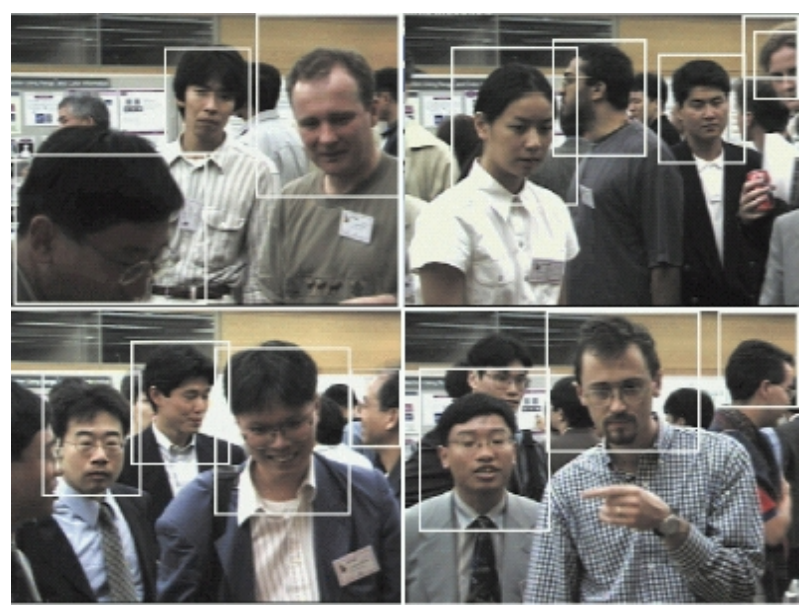

Figura 1.5: Resultados obtidos por Yachida et al. (1999)

\subsubsection{Geometria da Face}

Em muitas técnicas de detecção de face, o conhecimento da geometria da face tem sido empregado para caracterizar e, posteriormente, verificar várias características faciais em seus estados de incerteza (HJELMAS, 2001). Jeng et al. (1998) propõem um sistema para detecção de faces baseado em modelo geométrico de face. Nesse sistema, inicialmente tenta-se estabelecer as possíveis localizações dos olhos em imagens binarizadas. Para cada possível par de olhos o algoritmo buscará por um nariz, uma boca, e sobrancelhas. Cada característica facial tem uma função de avaliação associada, que é utilizada para determinar a face candidata. O sistema apresentou uma taxa de detecção de $86 \%$ em um banco de dados de 114 imagens. O sistema não é capaz de fazer uma correta detecção, quando existem múltiplas faces ou nenhuma na imagem.

Um método desenvolvido por Yow \& Cipolla (1997) usa filtros Gaussianos para localizar características semelhantes a barras horizontais nas imagens. Assim, características alongadas tal como olhos e boca são localizadas. Comparando-se suas relações com a de um modelo de face, possíveis faces são localizadas. Mudando-se o tamanho do filtro Gaussiano, esse método pode detectar faces de diferentes tamanhos em uma imagem. Os autores encontraram uma taxa de sucesso na detecção de faces de $85 \%$ sobre uma base de dados de 110 imagens de faces com diferentes escalas, orientações e ângulos. Algumas imagens utilizadas nos testes com o algoritmo de Yow \& Cipolla (1997) são mostradas nas Figuras 1.6 e 1.7. 


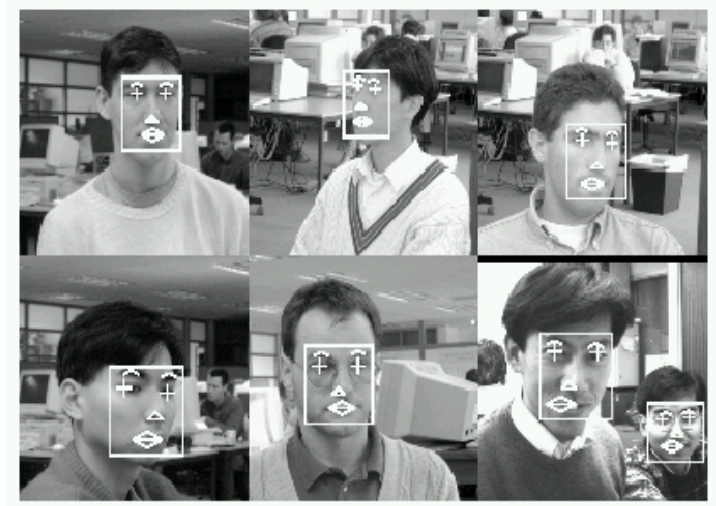

Figura 1.6: Resultado da Detecção de Faces em imagens de faces com diferentes escalas e ângulos

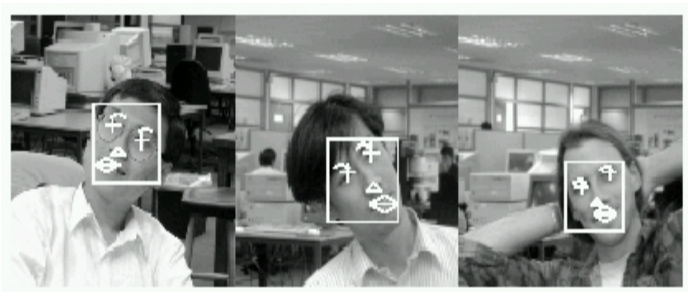

Figura 1.7: Resultado da Detecção de Faces em imagens com diferentes orientações

Alguns casos ineficazes são mostrados na Figura 1.8. Na primeira imagem, as sobrancelhas da pessoa são realmente muito perto dos olhos, e nesse ponto de vista, é indistinguível dos olhos. Entretanto, o algoritmo agrupa dois pontos na região do cabelo, formando à falsa evidência que conduz a uma identificação errada das características faciais. Na segunda imagem, a sobrancelha esquerda da pessoa (a sobrancelha direita na imagem) coincide bem com uma faixa horizontal escura no fundo. Em conseqüência, a sobrancelha é agrupada com a característica do fundo em uma característica longa, não sendo classificada como uma característica facial, resultando em uma configuração geométrica incorreta da face. Na terceira imagem, a face girou além do ângulo que o algoritmo pode detectar.

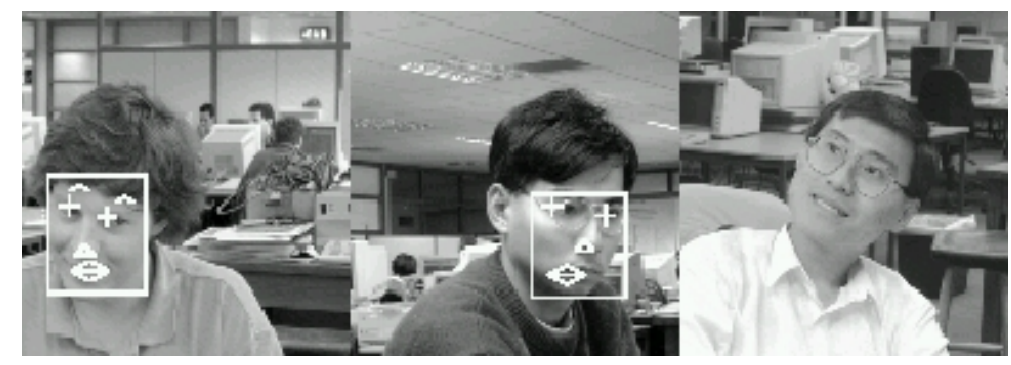

Figura 1.8: Resultados obtidos por Yow e Cipolla (1997)

Lin \& Fan (2001) desenvolveram um sistema para detecção de face humana utilizando as relações geométricas do triângulo. Este sistema possui duas partes principais. A primeira parte consiste na procura pelas regiões de possíveis faces. A segunda parte executa a verificação de face.

A primeira parte do sistema é constituída de quatro passos. No primeiro passo, a imagem é lida e, logo a seguir, convertida em uma imagem binária. No segundo passo, 
rotula-se todos os componentes 4-conectados na imagem para formarem vários blocos e encontrar o centro de cada um deles. No terceiro passo, detecta-se qualquer três centros de três diferentes blocos que formem um triângulo isósceles (imagem frontal) ou um triângulo retângulo (imagem de perfil). No quarto passo, junta-se os blocos que satisfazem ao critério do triângulo como a região de possível face.

A segunda parte do sistema é constituída de três etapas. A primeira etapa é responsável por normalizar o tamanho de todas as regiões de possíveis faces. A segunda etapa é encarregada de fornecer a cada região de possível face normalizada um peso na função máscara. A terceira etapa é executar a tarefa de verificação por "thresholding" do peso obtido na etapa precedente.

Na Figura 1.9 é mostrado um diagrama com todas as etapas que o sistema desenvolve a partir da entrada da imagem até o resultado da detecção.

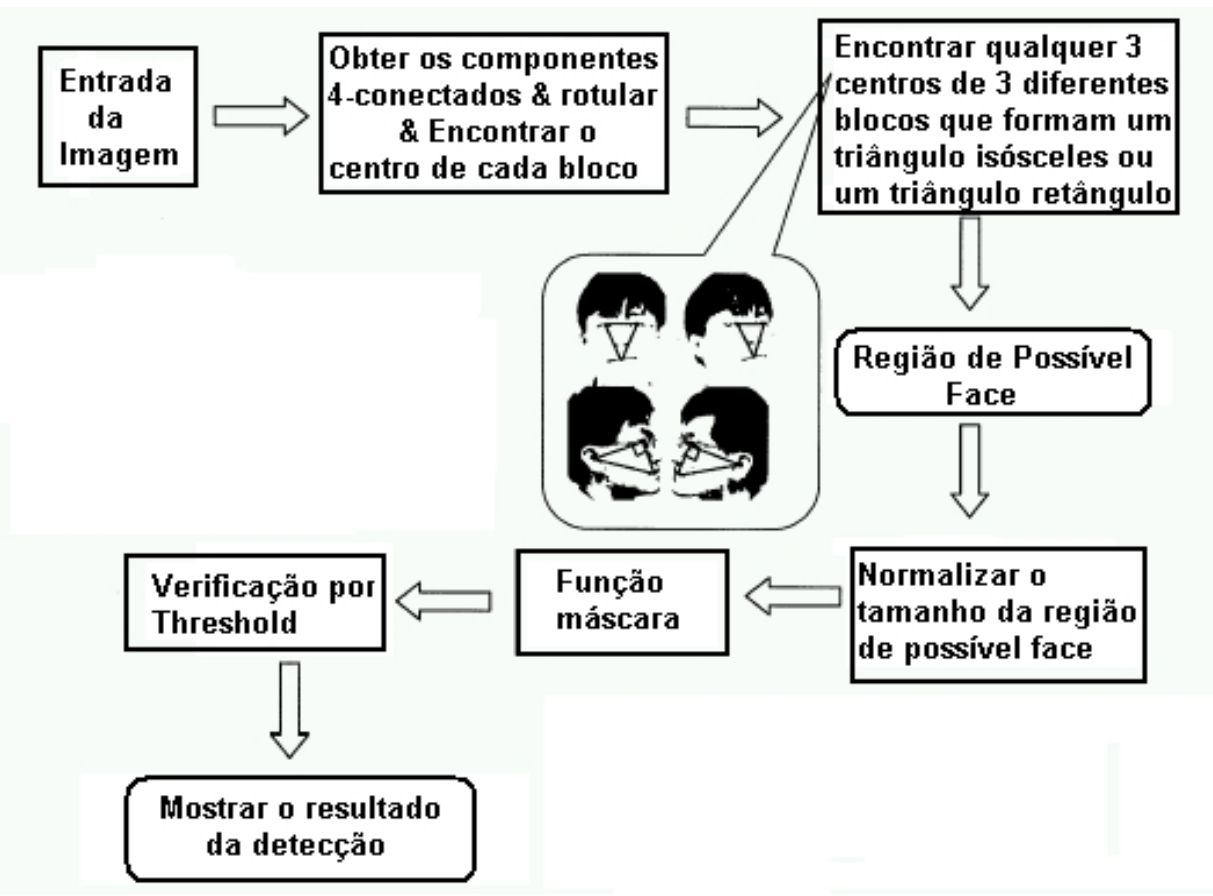

Figura 1.9: Visão geral do sistema de Lin e Fan (2001)

Este sistema pode trabalhar com: diferentes tamanhos de faces nas imagens, diferentes condições de iluminação, ruído, problema de desfocagem, variação de pose e de expressão. O sistema pode também detectar faces de perfil, face com problema de oclusão parcial da boca e face com óculos de sol.

Para validar a eficiência do sistema foram utilizadas 500 imagens de teste, de 450 pessoas diferentes, resultando no total de 600 faces. A taxa de sucesso desse sistema é de 
98\%. Na Figura 1.10 são mostrados alguns dos resultados obtidos pelo sistema proposto por Lin \& Fan (2001).

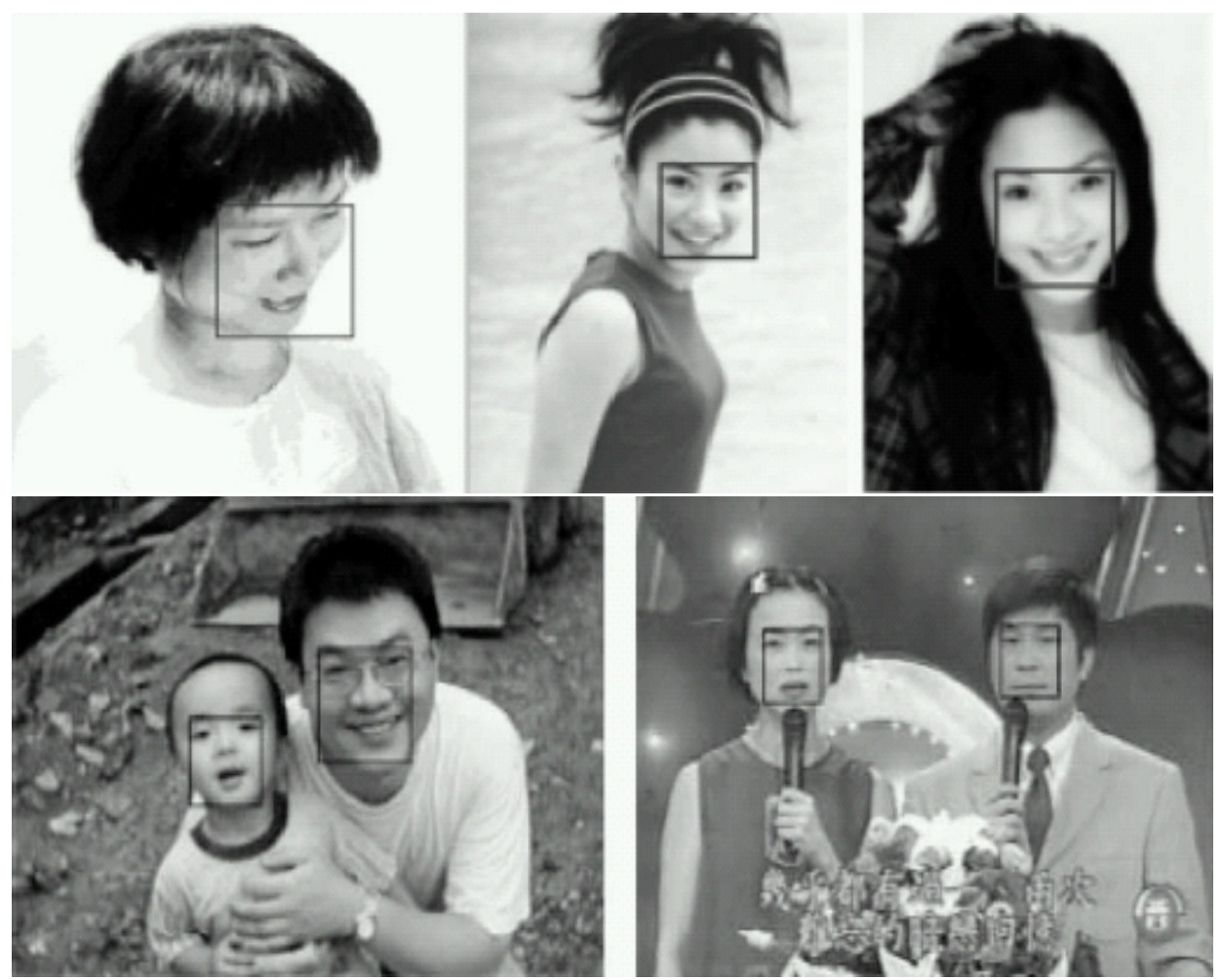

Figura 1.10: Alguns resultados do sistema proposto por Lin e Fan (2001)

Algumas falhas do sistema de Lin \& Fan (2001) são apresentadas nas Figuras 1.11 e 1.12 .

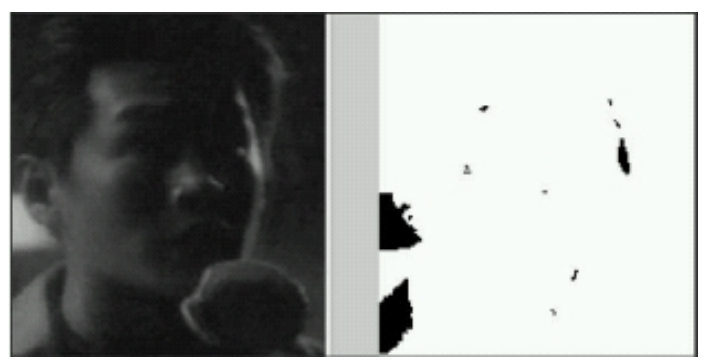

Figura 1.11: A face está muito escura para ser detectada
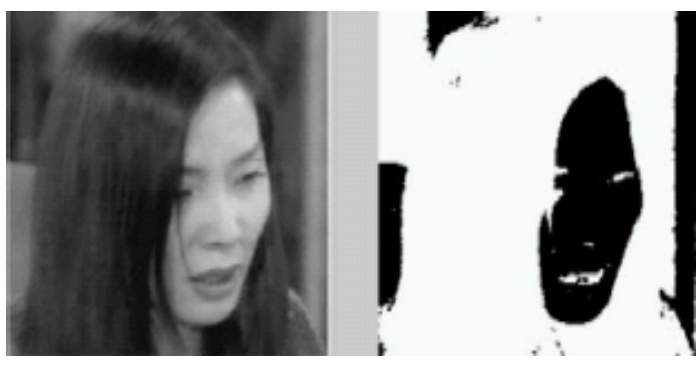

Figura 1.12: Face com oclusão do olho direito pelo cabelo preto 


\subsection{Considerações Finais}

Muitas pesquisas têm sido apresentadas no intuito de solucionar os problemas de detecção de face. Entretanto, cada uma destas abordagens apresenta suas vantagens e desvantagens durante a tarefa de detecção. Pode-se perceber este fato através dos métodos de detecção supracitados.

Na tentativa de buscar caminhos alternativos para os problemas de detecção, esta pesquisa traz uma técnica inovadora que é a utilização de medidas biométricas, mensuradas em imagens digitalizadas de faces humanas. A partir do estudo de tais medidas, torna-se possível a verificação de proporções existentes na face, especialmente a Proporção Divina, sendo esta a base para o algoritmo de detecção de face implementado neste projeto de mestrado. 


굴

\section{A Proporção Divina}

\subsection{Introdução}

Um dos aspectos ainda não explorados na área de Biometria de Faces Humanas através de técnicas de Processamento de Imagens, é o que envolve a estética das proporções presente não somente nos seres vivos, mas em toda a natureza.

"Estética, tradicionalmente, significa estudo racional do belo, quer quanto à possibilidade de sua conceituação, quer quanto à diversidade de emoções e sentimentos que ele suscita no homem". Esta definição é encontrada no dicionário da língua portuguesa do Prof. Aurélio Buarque de Holanda, Segunda edição, 1986.

A preocupação com a estética e a harmonia da natureza e do homem existe desde a Grécia Antiga (BEARDSLEY, 1966), e foram os filósofos gregos que introduziram o estudo da beleza e a filosofia da arte. Para eles as belas criações respeitavam certas leis geométricas, pois acreditavam que a verdadeira beleza necessariamente exibia harmonia. Esta última significava "adequada observação de proporções" (GUTHRIE, s.d.), portanto parecia razoável aceitar que estas proporções definiam sistemas fixos (CARPENTER, 1959). 
Enquanto os filósofos gregos formalizavam o estudo da beleza, os escultores expressavam-na em sua arte. A escultura grega desenvolveu-se nos séculos IV e V a.C., e leis ou regras foram estabelecidas para as proporções corporais ideais; de igual modo, as harmonias anatômicas foram relacionadas nas representações humanas (GUTHRIE, s.d.), desde a época dos antigos Egípcios.

Policleto canonizou o estudo matemático da beleza na Grécia Clássica. Em sua estátua Doryphoros, o cálculo do corpo é baseado em sete vezes e meia a altura da cabeça (PANOFSKY, 1976). Vitrúvio, um arquiteto romano que viveu no século I a.C. também definiu em sua obra certas relações entre as proporções do corpo humano (Figura 2.1): “(...) com efeito, não se pode falar de uma obra bem realizada, se não existir esta relação de proporção, regulada tal como está no corpo de um homem bem formado. A natureza fez o corpo humano de maneira que o rosto, distância que vai da raiz dos cabelos até o queixo, é 1/10 da altura total do corpo; a cabeça, distância entre o topo e o queixo, é 1/8 da altura total (...)".

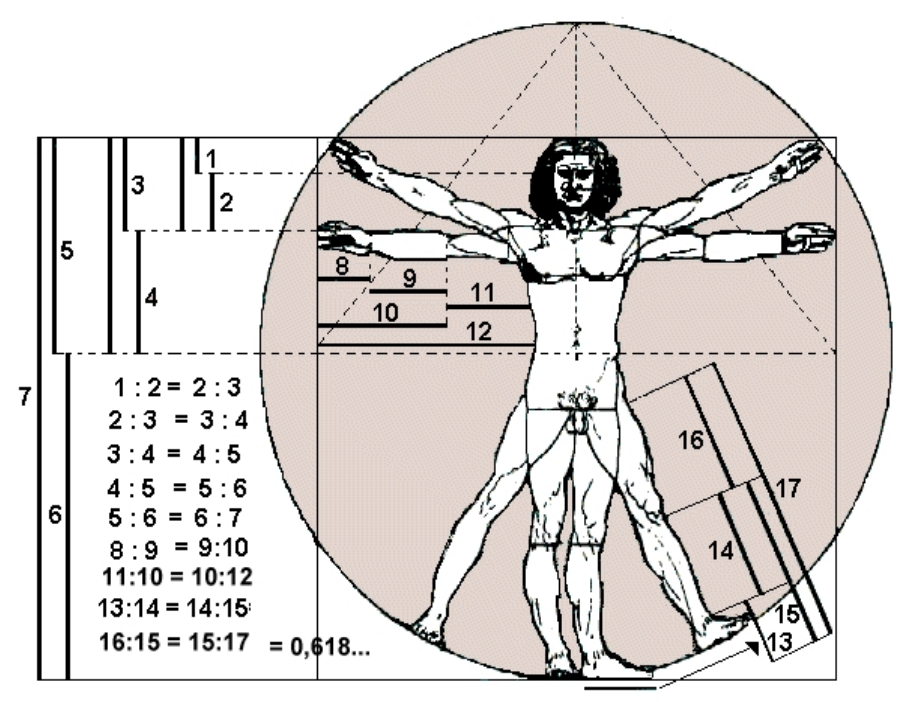

Figura 2.1: Estudos de Vitrúvio sobre as Proporções Humanas 


\subsection{A História da Proporção Divina}

O Número de Ouro é um número irracional misterioso e enigmático que surge numa infinidade de elementos da natureza na forma de uma razão, sendo considerada por muitos como uma oferta de Deus ao mundo:

$$
\Phi=\frac{1+\sqrt{5}}{2} \simeq 1.61803398
$$

A designação adotada para este número, $\Phi$ (Phi maiúsculo), é a inicial do nome de Fídias, escultor e arquiteto encarregado da construção do Parthenon, em Atenas.

Um exemplo dessa construção é o fato de que se desenharmos um retângulo, cujos lados tenham uma razão entre si igual ao número de ouro, este pode ser dividido num quadrado e noutro retângulo. Este último retângulo obtido pela divisão anterior possuirá, também, a razão entre os dois lados igual ao número de ouro. Este processo pode ser repetido indefinidamente mantendo-se a razão constante, conforme pode ser visto na Figura 2.2.

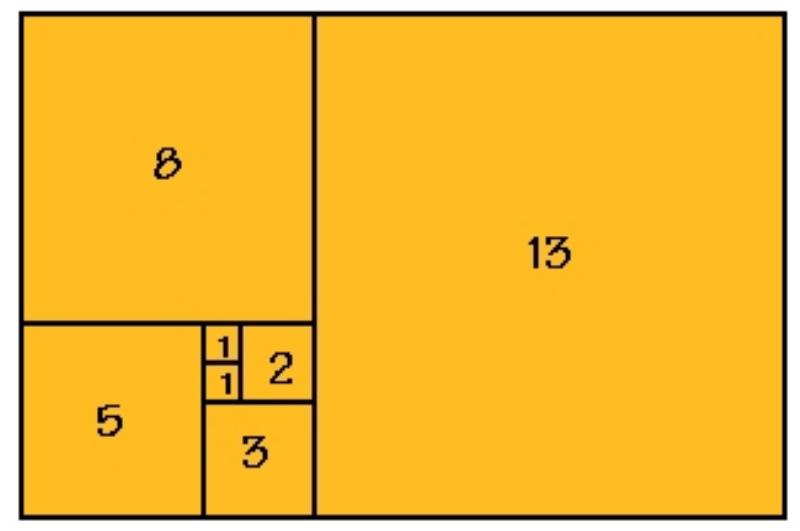

Figura 2.2: Retângulo Áureo 


\subsubsection{A História do Número de Ouro}

A história deste enigmático número perde-se na antiguidade. No Egito, as Pirâmides de Gizé (Figura 2.3) foram construídas considerando a razão áurea: "A razão entre a altura de uma face e a metade do lado da base da grande pirâmide é igual ao número de ouro" (Figura 2.4). O Papiro de Rhind refere-se a uma "Razão Sagrada", que acredita-se ser o número de ouro. Esta razão ou secção áurea surge em muitas estátuas da antiguidade.

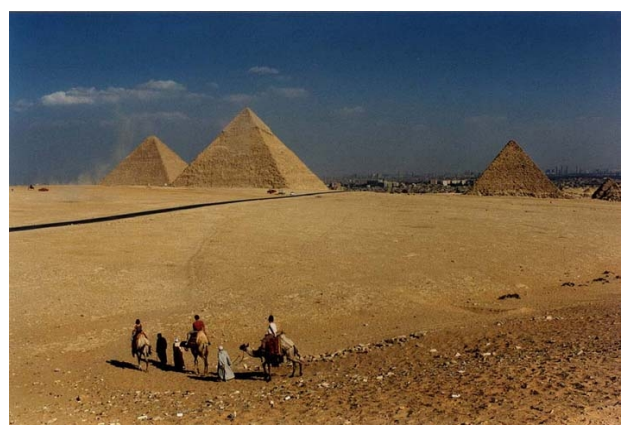

Figura 2.3: Pirâmides de Gizé

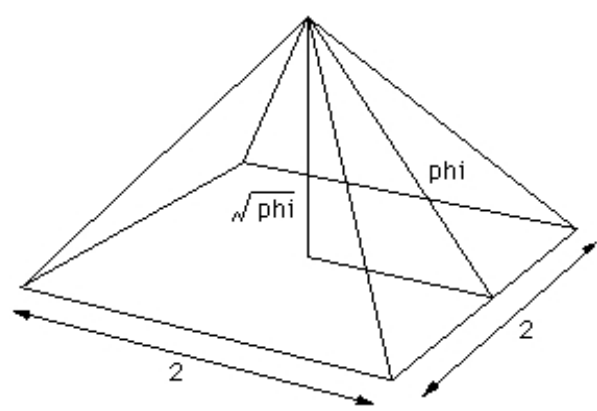

Figura 2.4: Pirâmide com Razão Áurea

Construído centenas de anos depois entre 447 e 433 a.C., o Parthenon (Figura 2.5), templo representativo do século de Péricles, também possui a razão áurea no retângulo que contêm a fachada (Largura / Altura)(Figura 2.6), revelando a preocupação de realizar uma obra bela e harmoniosa.

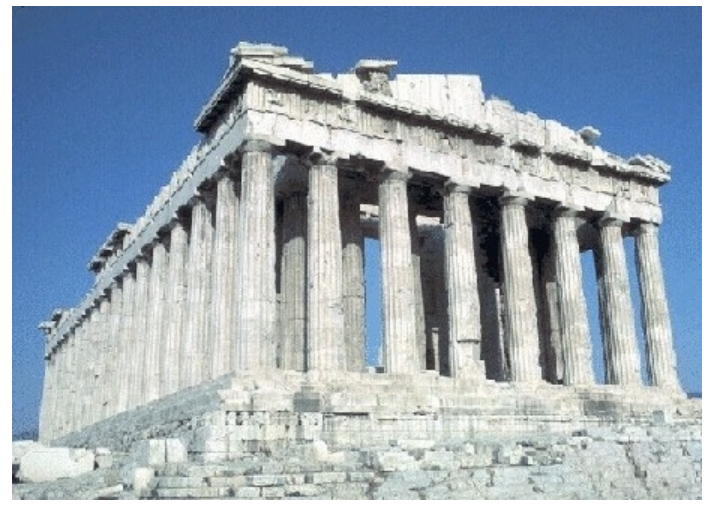

Figura 2.5: O Parthenon

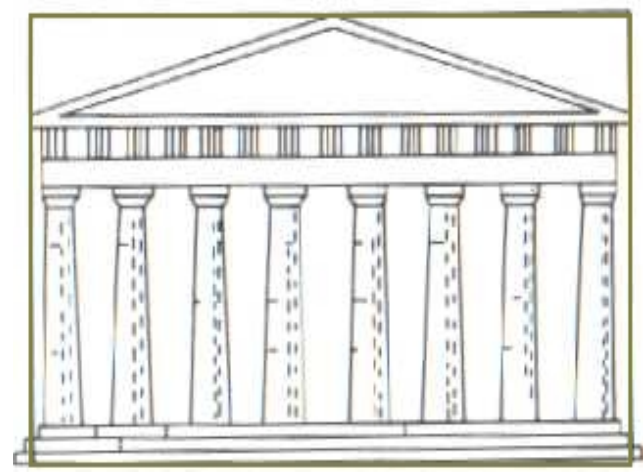

Figura 2.6: Sua fachada é um Retângulo Áureo

O retângulo aparece em muitas proporções do Parthenon, cuja elevação dianteira é constituída por um retângulo áureo. Este foi construído para a deusa "Atena" e atualmente encontra-se em ruínas. As proporções do Parthenon ${ }^{1}$, mostram a maneira que os gregos

\footnotetext{
${ }^{1}$ Veja outros exemplos de proporções do Parthenon na seção 2.7
} 
usavam deliberadamente a proporção áurea (HUNTLEY, 1970). Os gregos, assim como os egípcios, usaram a razão áurea para projetar seus "edifícios” e monumentos.

A razão áurea foi tema de preocupação do famoso geômetra grego Euclides, autor de "Os Elementos", primeira grande obra de geometria terminada em Alexandria, em 300 a.C., e considerada até hoje o melhor livro escrito de matemática elementar (COXETER, 1961). A obra embasou os Sólidos Platônicos, que representaram a culminação das descobertas marcantes da idade épica da matemática grega. Euclides pôs os toques finais a teoria da proporção áurea e mostrou como construir a proporção áurea com somente compasso e régua.

Os Pitagóricos também usaram a secção áurea na construção da estrela pentagonal. Não conseguiram exprimir como quociente entre dois números inteiros, a razão existente entre o lado do pentágono regular estrelado (pentáculo) e o lado do pentágono regular inscritos numa circunferência (Figura 2.7). Quando chegaram a esta conclusão ficaram espantados, pois tudo era muito contrário a toda a lógica que conheciam e defendiam; e lhe chamaram irracional.

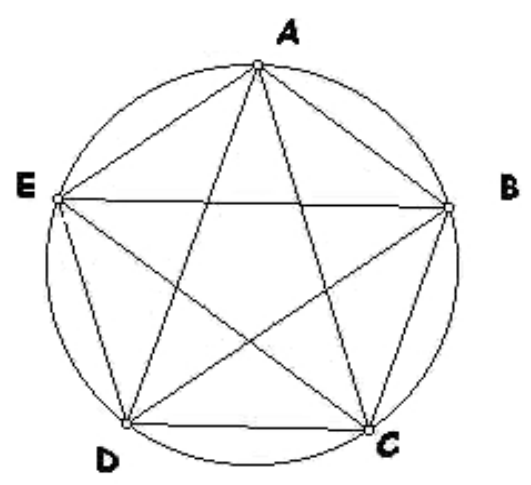

Figura 2.7: Estrela de Cinco Pontas com Proporções Áureas

Foi o primeiro número irracional de que se teve consciência que o era. Este era o número de ouro ${ }^{2}$ ou secção áurea ${ }^{3}$, apesar deste último nome só lhe ser atribuído vários séculos depois.

Posteriormente, os gregos consideraram que o retângulo, cujos lados apresentavam a seção áurea possuía uma especial harmonia estética, a qual chamaram retângulo áureo considerando a harmonia uma virtude excepcional.

Uma contribuição preciosa nos foi dada por Fibonacci, o "maior matemático europeu” da Idade Média. Nascido em Pisa, Itália, em aproximadamente, 1175 d.C., era também

\footnotetext{
${ }^{2} \mathrm{O}$ apêndice $\mathrm{B}$ possui mais informações a respeito do número de ouro.

${ }^{3} \mathrm{O}$ apêndice B possui mais informações a respeito da secção áurea.
} 
conhecido como Leonardo de Pisa ou Leonardo Pisano. A contribuição de Fibonacci para o número de ouro está relacionada com a solução do Problema dos Pares de Coelhos, a seqüência de números de Fibonacci, publicado no seu livro Liber Abaci (SODRÉ, 2003).

A sequiência de números de Fibonacci ${ }^{4}$ é: $0,1,1,2,3,5,8,13,21 \ldots$, sendo que, somando os dois últimos obtemos o próximo número ou o número é a soma dos dois precedentes. As sucessivas razões entre um número e o que o antecede vão-se aproximando do número de ouro, ou seja, os números da secção áurea, que são: +/- 0,6180339887 e +/- 1,6180339887. A sequiência áurea é uma sucessão de zeros (0) e uns (1), estando relacionada quer com os números de Fibonacci, quer com a secção áurea.

Outro matemático que contribuiu para o estudo e divulgação do número de ouro foi Luca Pacioli (1445-1514), frade franciscano que interpretou a matemática numa perspectiva técnica. Com o intuito de aprender a ciência da contagem com os árabes, viajou pelo Oriente, tendo no seu regresso ensinado matemática em várias cidades italianas, como Milão e Bolonha.

Em 1509 publicou "De Divina Proportione" defendendo que dos corpos regulares emanam a "virtude", uma vez que não sendo simples contribuem para a formação de todos os outros. Aos arquitetos recomendou a utilização de cinco poliedros "uma vez que ... servem de sugestão e de objeto de meditação ... pela Divina Proporção que os rege". "Estas figuras são chamadas, por todos os sábios, corpos regulares". "Não é possível relacionar entre si os cinco corpos regulares, nem inscrevê-los numa esfera sem conhecer a nossa proporção".

Para Pacioli, tal como para Vitrúvio, o Homem é a medida de todas as coisas; sendo que até as medidas dos edifícios foram deduzidas a partir do corpo humano. Esse matemático considerou também que a Divina Proporção tem cinco propriedades fundamentais:

1 - é única;

2 - é a única proporção com três termos;

3 - não se pode expressar com números inteligíveis, mas sim com números irracionais;

4 - é sempre semelhante a si própria;

5 - permite formar o dodecaedro, o qual Platão chamou a "quinta essência".

Sem esta proporção não se consegue formar os cinco sólidos platônicos (tetraedro, hexaedro, octaedro, icosaedro e dodecaedro), sendo o mais complexo, o quinto.

\footnotetext{
${ }^{4}$ Para uma melhor explanação sobre a seqüência de Fibonacci, veja o Apêndice B.
} 
Além disso, Pacioli afirmou que os templos antigos eram projetados e concebidos de acordo com a figura humana inscrita no círculo e no quadrado, porque o Homem era o espelho do Universo.

Uma contribuição que não pode ser deixada de referir foi a de Leonardo Da Vinci (1452-1519) . Dotado de uma imaginação brilhante e sendo um grande observador da Natureza, tornou-se famoso pela sua grande versatilidade (era pintor, escultor, engenheiro e arquiteto) e pela sua genialidade (o desenvolvimento de estudos em várias áreas, como anatomia e engenharia militar). Era um gênio de pensamento original que usou exaustivamente os seus conhecimentos de matemática, especificamente o número de ouro nas suas obras de arte.

Nos finais de 1480, enquanto trabalhava no monumento de Francesco Sforza, Leonardo abordou pela primeira vez estudos intensivos e extensivos das proporções do corpo humano, usando fisiologia e anatomia, e em 1489, iniciou o livro "On the human figure", o qual nunca chegou a terminar. Fez também estudos sistemáticos sobre a massa corporal usando dois jovens e obteve ao fim de vários meses de medições, uma visão sistemática das proporções humanas. Ele comparou o seu estudo antropométrico, apontando as medidas humanas, com a única teoria das proporções da Antiguidade que havia sobrevivido; "O Homem de Vitrúvio".

Vitruvius, arquiteto e engenheiro bem sucedido do Império Romano, escreveu um Tratado de Arquitetura em vários livros. No Livro Terceiro incluiu a descrição completa das medidas do corpo humano, o que o levou a concluir que um homem com as pernas e os braços abertos caberia, perfeitamente, dentro de um quadrado e de um círculo (figuras geométricas perfeitas). Assim, se a figura fosse representada dentro de um círculo ("homo ad circulum") e de um quadrado ("homo ad quadratum"), então, o centro do corpo coincidiria com o umbigo (Figura 2.8).

Esta visão e as medidas de Vitruvius foram no Renascimento, e mesmo mais tarde, freqüentemente ilustradas, embora com resultados bastante diversos. A ilustração mais conhecida é o desenho de Leonardo da Vinci, no entanto, ele não se preocupou com qualquer relação geométrica entre o círculo e o quadrado, o que leva-nos a pensar que no desenho as duas figuras não estejam limitadas pela sua relação mútua.

Leonardo baseou-se nas suas próprias descobertas, fruto de longos meses de estudo, tendo corrigido as inconsistências existentes nas medidas de Vitrúvio, alterando assim os pés e as mãos para um tamanho adequado. 


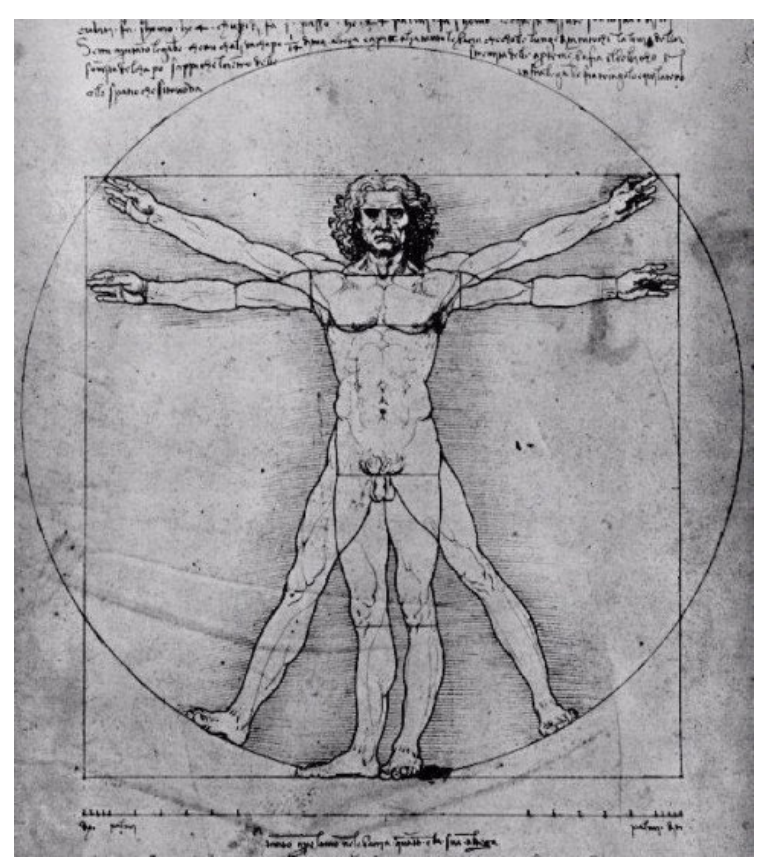

Figura 2.8: As Proporções da Figura Humana - 1490

Desse modo, só o centro do círculo à volta do "homo ad circulum" coincide com o umbigo, estando o quadrado que encerra o "homo ad quadratum" um pouco mais abaixo.

Leonardo da Vinci considerava que as proporções perfeitas do Homem deviam basear-se no número de ouro marcando no umbigo o ponto da secção áurea.

Todas as partes do corpo humano guardam entre si a relação áurea. São exemplo dessa afirmação:

- o comprimento do braço e do antebraço;

- altura da pessoa e a altura que se encontra o coração.

Assim, Leonardo criou a imagem que é aceita como a verdadeira representação das descobertas de Vitrúvio. A excelência dos desenhos revela os seus conhecimentos matemáticos, bem como a utilização da razão áurea como garantia de perfeição, beleza e harmonia únicas.

Albert Dürer (1471-1538) dedicou-se também ao estudo do corpo humano (Figura 2.9), tendo como base os textos de Vitrúvio. Trabalhando ao lado de Jacopo de Barbari (retratado por Pacioli), descobriu o problema da beleza proporcional e da secção áurea, desenhando em 1521, o Homem Vitruviano. 


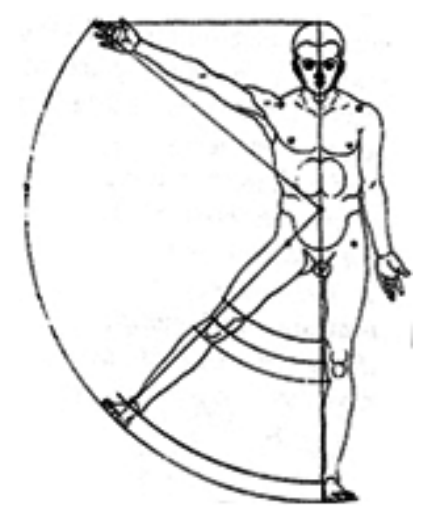

Figura 2.9: "Livro sobre as Proporções Humanas”, Albercht Dürer, desenho de 1521

O umbigo do homem vitruviano está colocado em relação ao chão, em secção áurea. Isto relaciona com os escritos em 1528, de Dürer onde afirma: "a justa proporção conduz à beleza da linha e isso não só num quadro, mas em todas as coisas que se podem criar, modelando-as".

Outro destaque foi Le Corbusier, arquiteto, pintor e escritor (1887-1965), o qual baseou o seu sistema modular de proporção na série de Fibonacci. Ao seu sistema de proporções e medidas, Le Corbusier chamou "Modulor"5. Este é constituído por duas partes: A e B. A letra (A) corresponde à primeira coluna do desenho mostrado na Figura 2.10 que é baseada na altura de um homem comum, $1829 \mathrm{~mm}$. Se esta altura for dividida de acordo com a secção áurea, o comprimento das duas partes será de $1130 \mathrm{~mm}$. Esta medida corresponde à altura do umbigo, que novamente dividida de acordo com a secção áurea, resulta na medida de $698 \mathrm{~mm}$. Se continuarmos dividindo e subdividindo de acordo com a relação áurea, encontraremos uma série de medidas relacionadas entre si. Já a segunda coluna (B) é obtida da mesma forma, porém o ponto de partida é a altura do homem comum com o braço levantado.

\footnotetext{
${ }^{5}$ O Apêndice B, traz mais explicações sobre o "Modulor".
} 


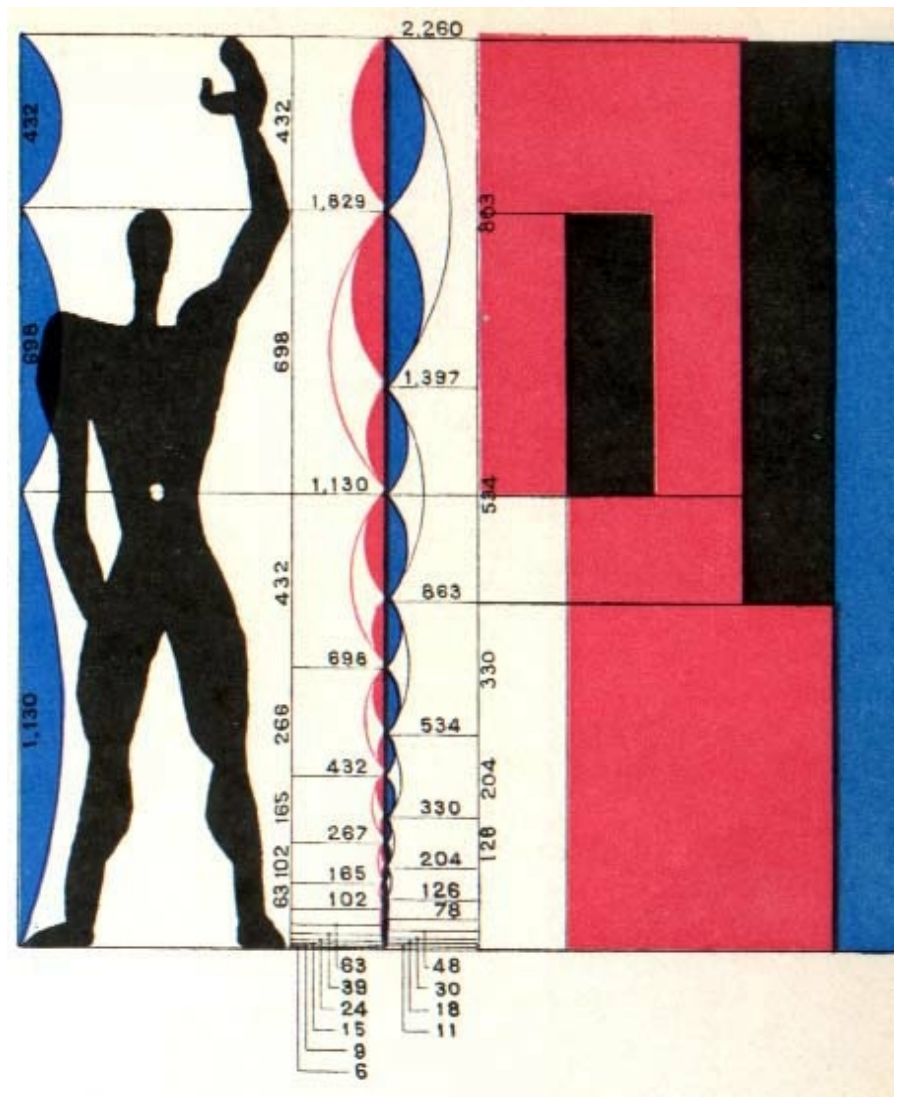

Figura 2.10: Proporções do Corpo

\subsection{A Proporção Divina}

“O que é Beleza?". A beleza está somente nos olhos do observador, ou pode ser mensurada? Beleza é um mistério!

"Eu não sei o que a beleza é, mas sei que ela pincela muitas coisas", Dürer (LEVIN, s.d.).

O estudo da beleza da natureza, das pessoas, das construções, das artes, revela um princípio comum que as rege. Semelhante princípio, de forma geral, é o reconhecimento do prazer propiciado pela proporção das formas.

Pode-se afirmar que existe uma fisiológica e inata interdependência entre a sensorialidade humana e a proporção. Já Platão afirmava no Philebos: “o que entendo por beleza das formas ..." é “... o que é reto, circular, as superfícies e os corpos compostos com as retas e o círculo por meio dos esquadros e compassos". 
De acordo com a geometria euclidiana, a beleza e a harmonia das formas naturais podem traduzir-se em elementares e básicas relações matemáticas e geométricas. Na arte, referem-se elementos geométricos como a harmonia, o ritmo, a verticalidade, a simetria e as perpendiculares que se encontram na Natureza.

Os primeiros elementos geométricos universais presentes no Homem são a verticalidade e a horizontalidade por contraposição.

Inconscientemente, todos os dias os homens utilizam elementos proporcionais e que constituem, sem dúvida, referências geométricas fundamentais para a Humanidade.

A partir do período Renascentista, um dos principais aspectos de uma estrutura proporcional, que lhe confere beleza, passou a ter vários nomes, mas somente um número. Proporção Áurea, Secção Áurea, Razão Áurea, Secção Divina, Proporção Divina são algumas das muitas nomenclaturas representativas da misteriosa proporção expressa pelo número irracional $\Phi$.

Ao traçar um segmento $\overline{A B}$, pode-se dividi-lo em dois segmentos desiguais, valendose de um ponto $S$ e originando $\overline{A S}$ e $\overline{S B}$. Porém, só haverá uma maneira de localizar este ponto $S$, se existir a seguinte proporção: o segmento todo $(\overline{A B})$ dividido pelo segmento maior $(\overline{A S})$ será igual ao segmento maior $(\overline{A S})$ dividido pelo segmento menor $(\overline{S B})$, conforme mostra a Figura 2.11.

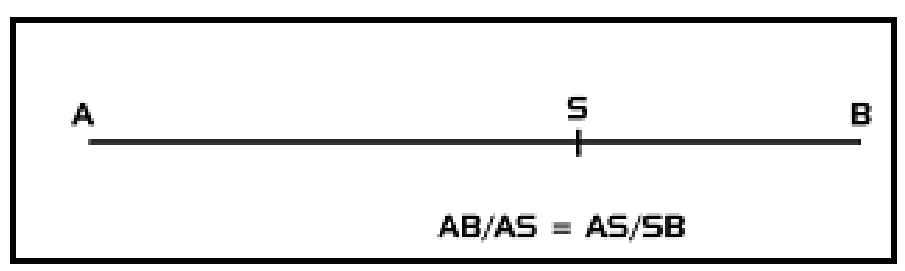

Figura 2.11: Segmento Áureo

Quando isso acontece, o ponto $S$ é chamado de ponto áureo. Na divisão áurea, a razão entre o todo e o segmento maior é expresso pelo número irracional, cujo valor é representado pela letra grega $\Phi$ (Phi maiúscula). Além do segmento áureo ${ }^{6}$, a proporção divina também define uma grande classe de formas geométricas proporcionais, largamente estudadas, que são encontradas na Natureza, nos produtos humanos, na Arte, na Arquitetura e também no Homem.

\footnotetext{
${ }^{6} \mathrm{O}$ apêndice $\mathrm{B}$ têm outras explicações sobre segmento áureo.
} 


\subsection{A Proporção Divina na Natureza}

O número de ouro aparece em vários aspectos da Natureza. Estudos desenvolvidos sobre a ocorrência de tal fenômeno têm mostrado que o número de ouro e as suas estruturas possuem motivos naturais que ultrapassam a barreira da beleza física.

Pode-se constatar o fenômeno do número de ouro através de alguns exemplos citados a seguir, tais como: a disposição de sementes de pólen em uma flor, o crescimento de ramos nos meristemas vegetais, o arranjo foliar, as conchas de moluscos marinhos, as ondas do mar e os peixes, os insetos, as disposições das cores nos corpos de diversos animais, a face dos tigres, o corpo dos golfinhos e pingüins. Todos estes apresentam o número de ouro como elo de semelhança ${ }^{7}$. Acredita-se que sua presença indica disposições de maior eficiência e desempenho quanto à conservação de energia.

\subsection{A Proporção Divina na Indústria, Comércio e Publi- cidade}

As Empresas usam formas proporcionais áureas de forma intuitiva, até mesmo porque as dimensões associadas representam algo bonito e econômico; mas é provável que muitos usuários das relações áureas nem saibam de sua fundamentação matemática. Por exemplo, um cartão de crédito parece ter a forma das medidas áureas (Figura 2.12), as quais são sempre relacionadas com o número $\Phi$, e as dimensões de veículos publicitários escritos (Figura 2.13), como cartazes e revistas, também delineiam a importância da razão divina (RANULFO, 2002).

\footnotetext{
${ }^{7}$ No Apêndice A podem ser visualizados estes exemplos
} 


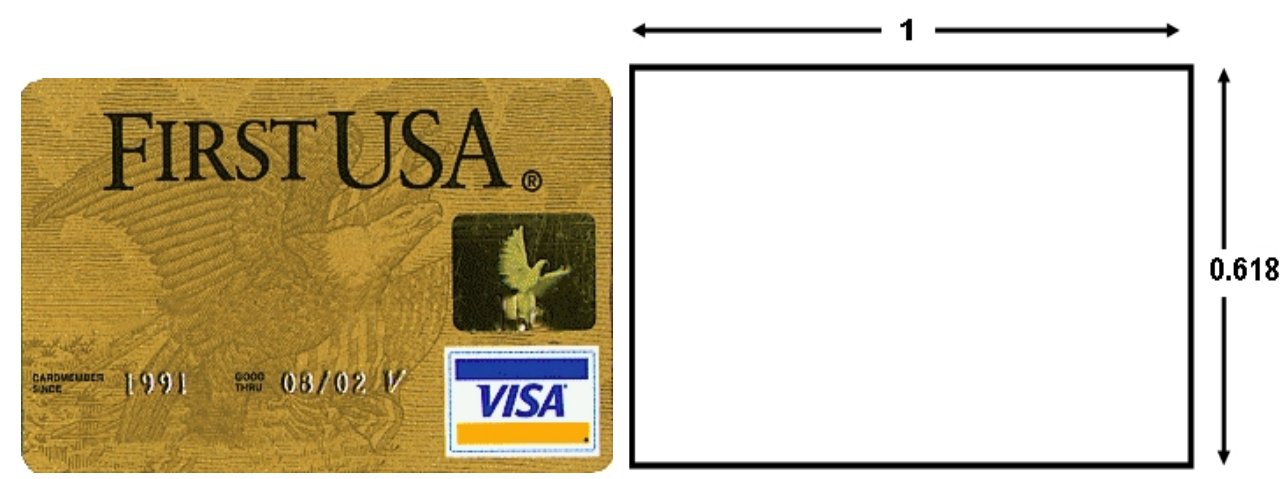

Figura 2.12: Cartões em Retângulo Áureo
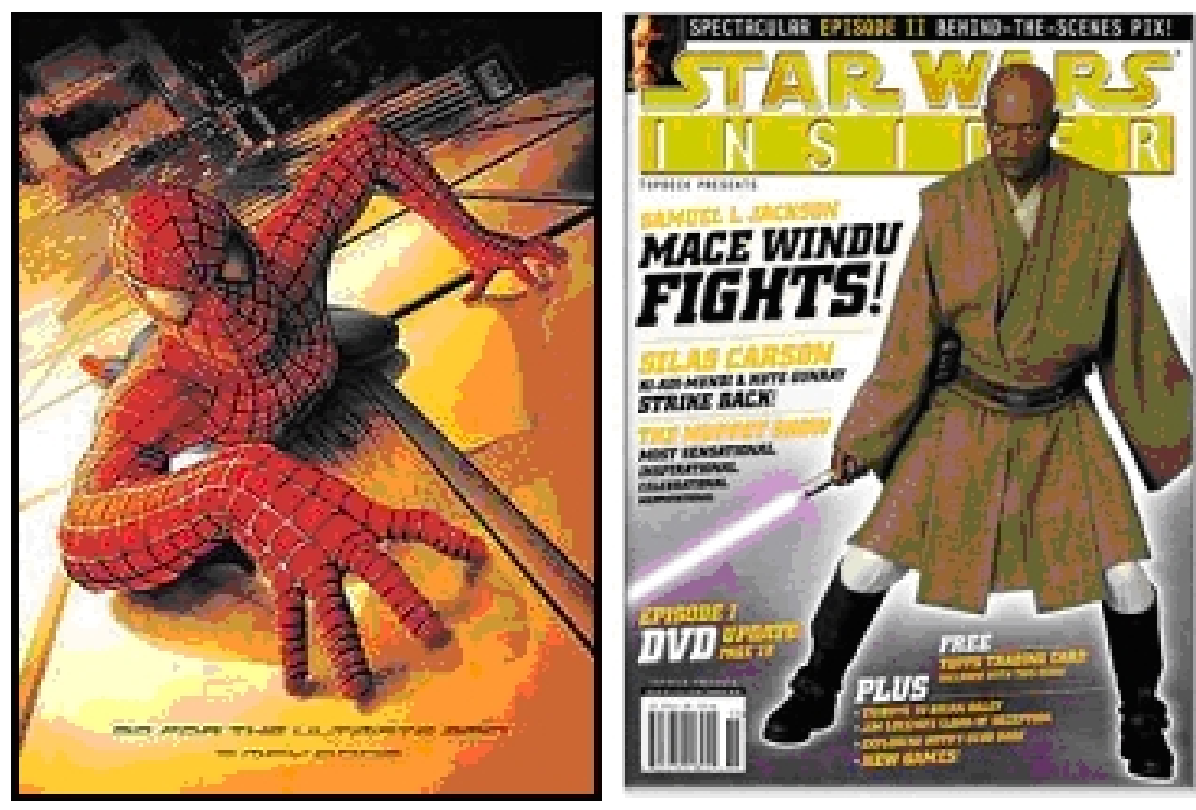

Figura 2.13: Cartaz publicitário e Revista em Retângulo Áureo

Na indústria automobilítica encontramos alguns exemplos da proporção divina sendo utilizada na modelagem de veículos e proporcionando desta maneira, beleza, harmonia e robustez. 

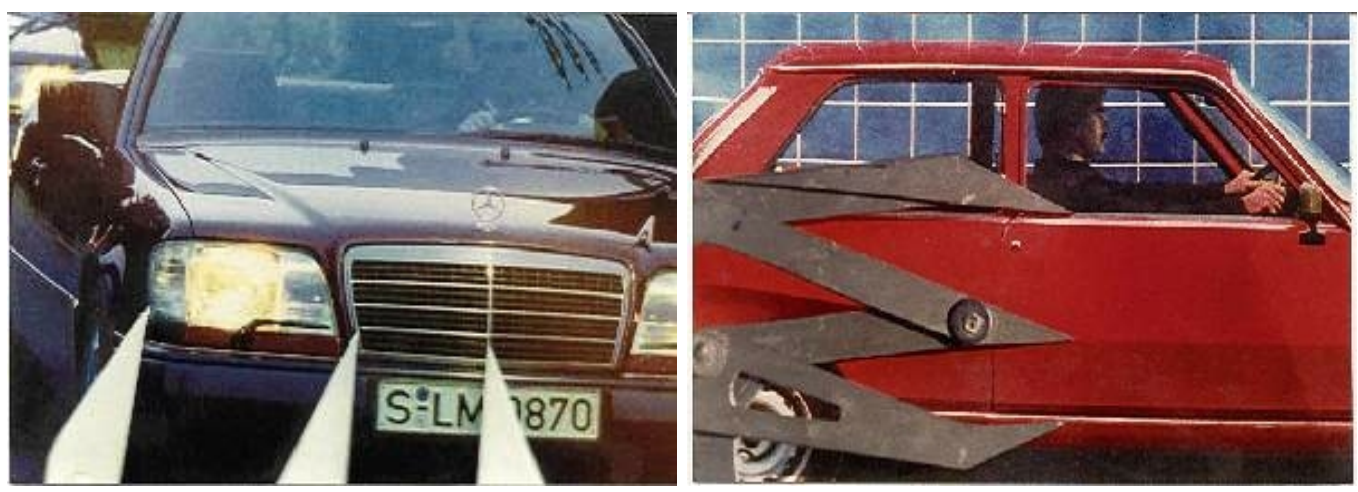

Figura 2.14: Carros modelados com Proporção Divina

Na Figura 2.14, pode-se ver um Medidor de Proporção Divina ${ }^{8}$, que indica o local onde comprova-se a existência dessa proporção divina.

\subsection{A Proporção Divina na Arte}

Desde tempos remotos a proporção divina é aplicada na arte. Assim, encontra-se o retângulo áureo, reconhecido como a forma visualmente mais equilibrada e harmoniosa nessa área. A proporção divina traduz a proporção geométrica conhecida e utilizada na pintura, na escultura e nas arquiteturas clássicas, renascentistas e pós-modernistas, baseando-se no seguinte princípio:

"seccionar um segmento de reta de tal forma que a parte menor esteja para a maior como este está para o todo".

Leonardo da Vinci afirmava que a arte deveria manifestar por ela própria um movimento contínuo e com beleza. Para atingir este fim, ele utilizou extensivamente o retângulo áureo nas suas obras.

\footnotetext{
${ }^{8}$ Para saber mais a respeito deste medidor e de outros exemplos sobre a Proporção Divina na Indústria, consulte o Apêndice A.
} 


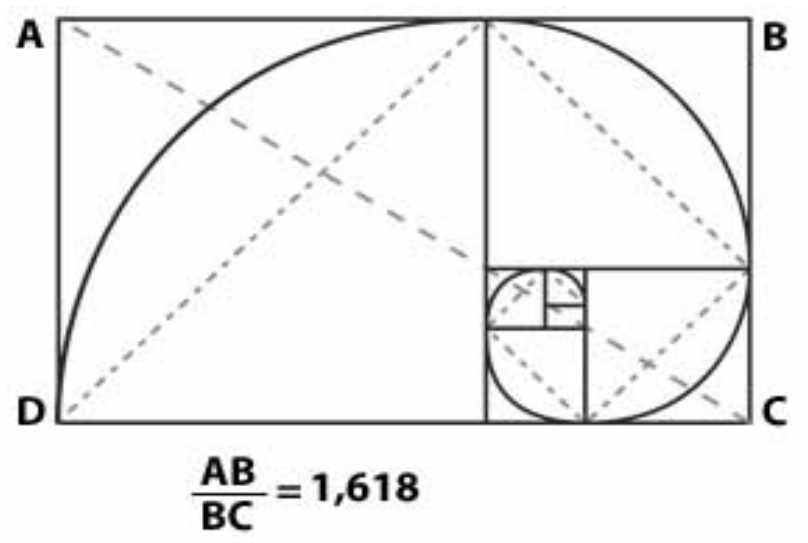

Figura 2.15: Retângulo Áureo que expressa uma espiral até o infinito

O retângulo áureo ${ }^{9}$ expressa movimento porque este permanece numa espiral até ao infinito, e mostra a beleza porque a razão áurea é agradável aos olhos (Figura 2.15).

Em um dos quadros mais célebres de Leonardo da Vinci; a Mona Lisa, (Figura 2.16)

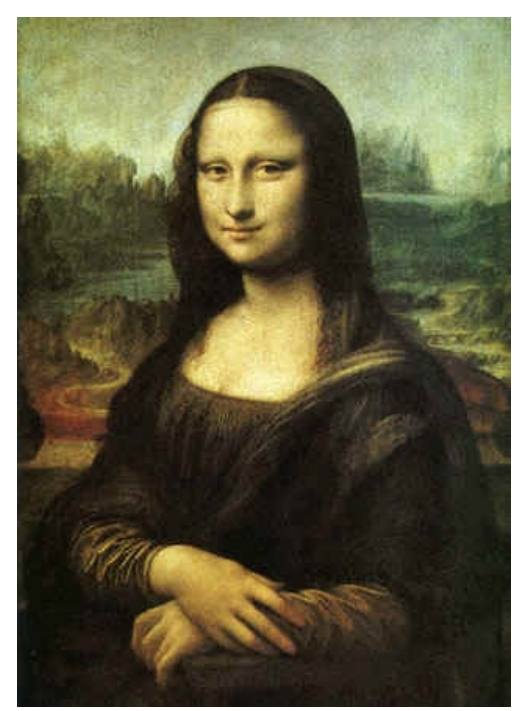

Figura 2.16: Mona Lisa

o retângulo áureo está presente em múltiplos locais:

- desenhando-se um retângulo em volta da face, o retângulo resultante é um retângulo áureo (Figura 2.17);

- dividindo-se este retângulo por uma linha que passe nos olhos, o novo retângulo obtido também é áureo;

\footnotetext{
${ }^{9}$ Para saber mais sobre o retângulo áureo e a espiral logarítmica consulte o Apêndice B.
} 
- as dimensões do quadro também representam a razão áurea.

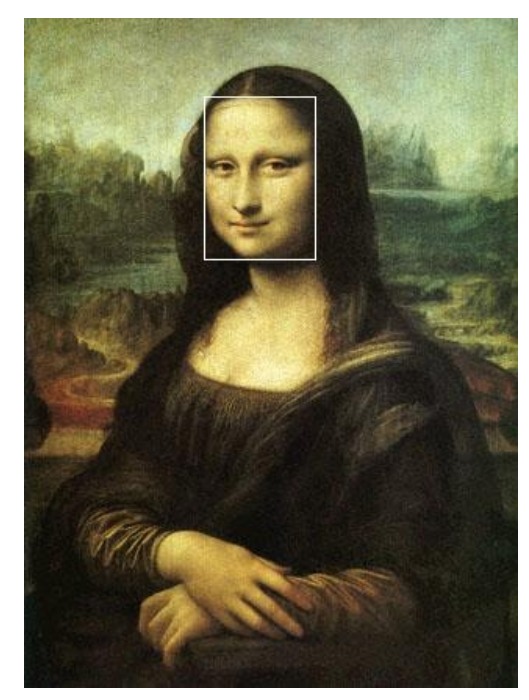

Figura 2.17: Mona Lisa e suas proporções faciais

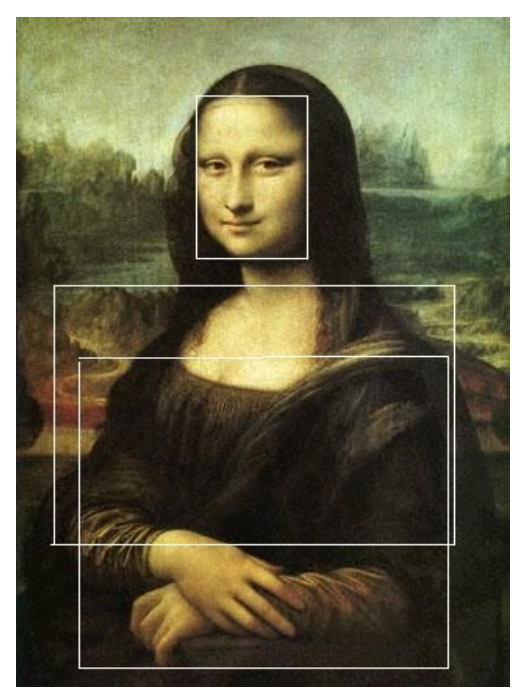

Figura 2.18: Mona Lisa e suas proporções corporais

Pode-se continuar explorando a proporção em outras partes do corpo, conforme mostra a Figura 2.18.

Um artista contemporâneo que utilizou a proporção divina na sua pintura, foi o pintor norte-americano Piet Mondrian (SILVA et al, s.d.). A Figura 2.19 mostra um exemplo da obra de Piet Mondrian:

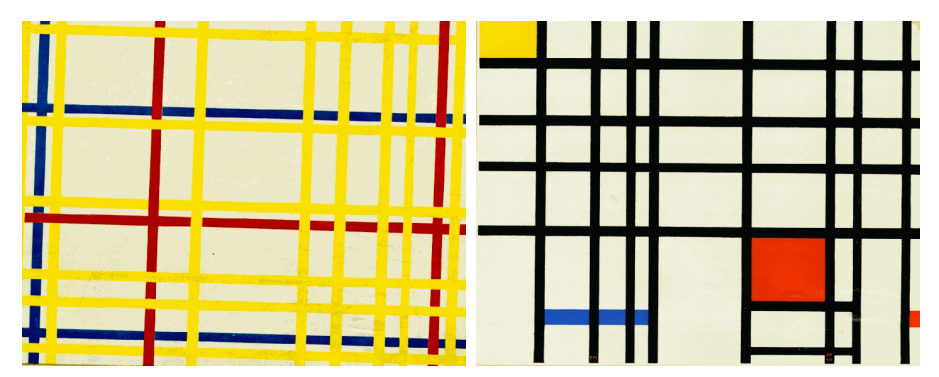

Figura 2.19: Pinturas de Piet Mondrian

\subsection{A Proporção Divina na Arquitetura}

Pode-se encontrar também, diversas aplicações da Proporção Divina na Arquitetura. 
Há exemplos sobre o modo como o retângulo áureo se ajusta à construção do Parthenon. O Parthenon, um dos templos construído em Athenas, concretiza a observação da proporção divina; a planta mostra que o templo tinha por base um retângulo com comprimento igual à raiz quadrada de 5 e largura igual a 1 (Figura 2.20).
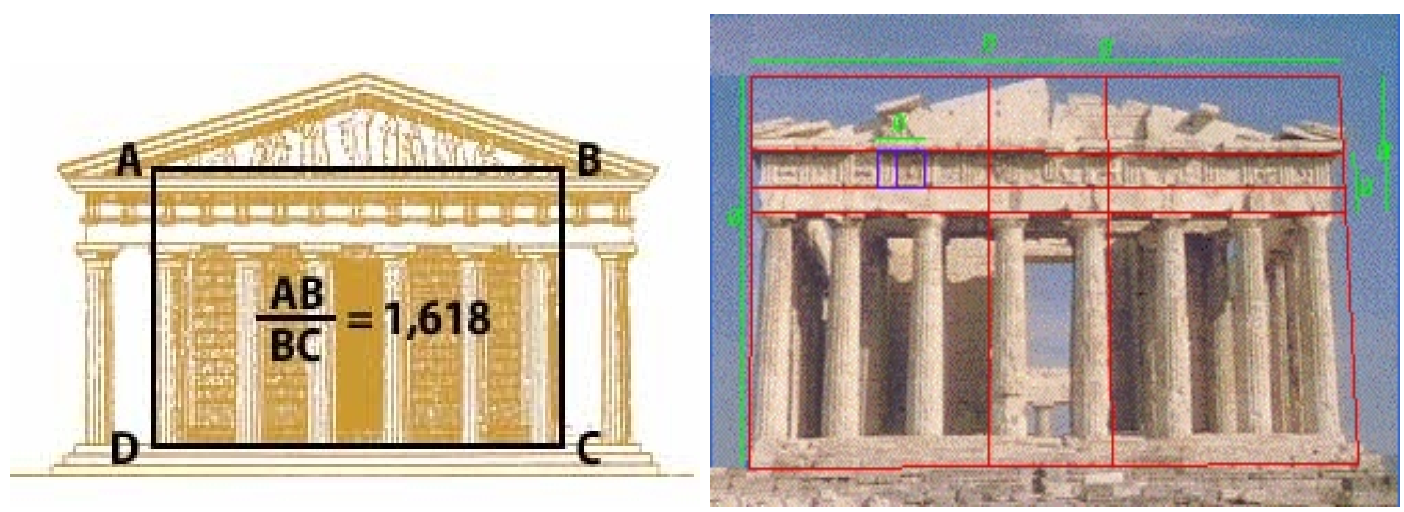

Figura 2.20: Alguns exemplos de Retângulos Áureos no Parthenon

Pode-se notar outras proporções contidas no Parthenon, ilustrada na Figura 2.21.
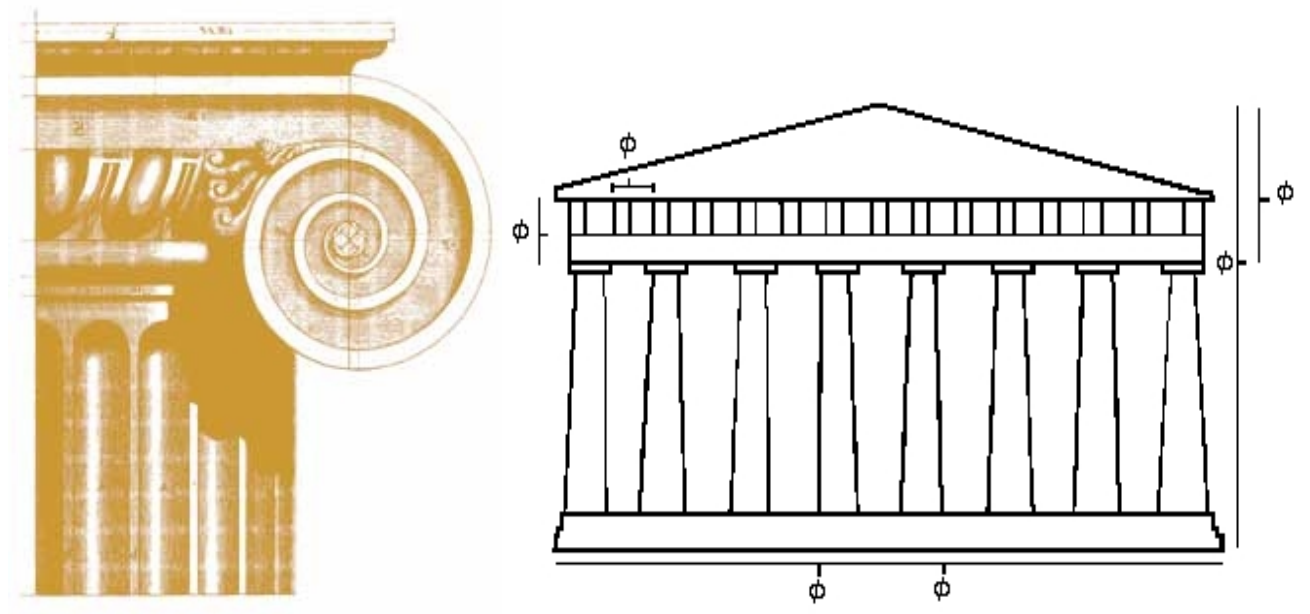

Figura 2.21: Outros exemplos de Proporção Divina no Parthenon

Assim como nas antigas arquiteturas encontramos nos dias de hoje em muitos monumentos e edifícios a Proporção Divina, como pode ser visto na Figura 2.22. 

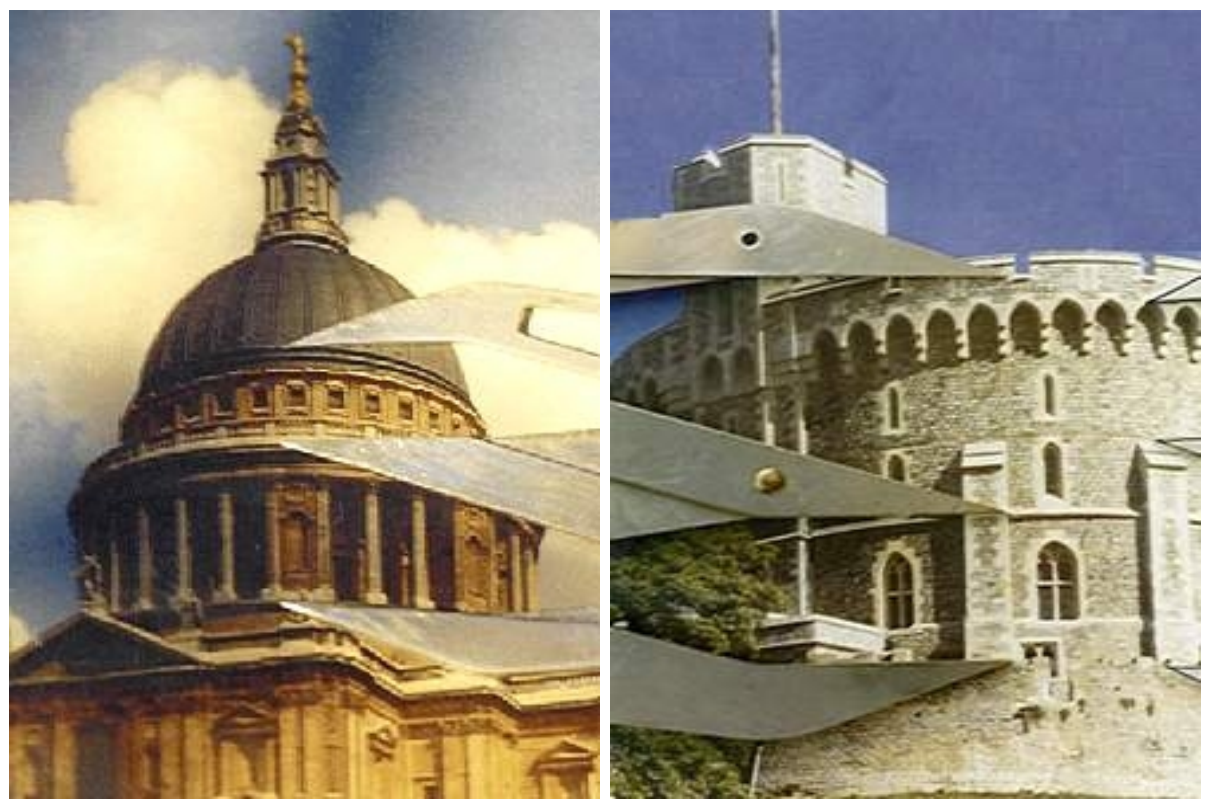

Figura 2.22: A Cúpula de St. Paul e o Castelo de Windsor, Londres

Neste edifício mostrado na Figura 2.23, percebe-se claramente que a estrutura é constituída por três retângulos áureos comprovando mais uma vez a utilização da proporção divina $^{10}$.
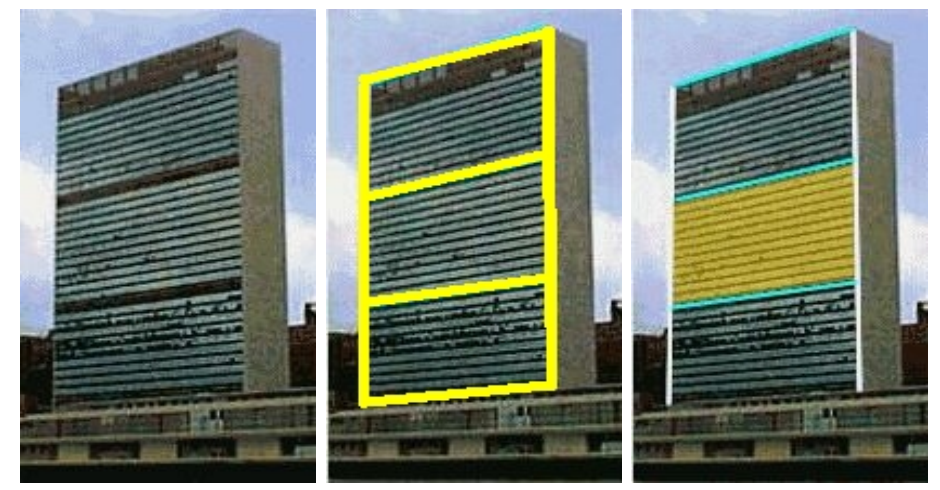

Figura 2.23: Edifício construído com Retângulos Áureos

${ }^{10} \mathrm{O}$ Apêndice A contém outros exemplos da Proporção Divina na Arquitetura. 


\subsection{A Proporção Divina no Homem}

A face humana é possivelmente a mais bela e perfeita estrutura encontrada no reino animal. A subjetividade da estrutura, a harmonia, o balanço e a proporção dos aspectos matemáticos e geométricos estão associados com a biologia do crescimento e da formação. Para se averiguar estes aspectos na face humana medidas particulares são definidas.

Para a análise frontal transversal, os seguintes marcos são destacados: a asa do nariz (parte mais larga) até o chilion (um ponto no ângulo da boca onde a mesma angula pra cima ou pra baixo); o ponto do canto lateral (canto externo) dos olhos; um ponto da base da ponte nasal (linha entre os olhos); e o ponto da extremidade da fronte ao nível das sobrancelhas. A Figura 2.24 ilustra estes marcos supracitados.

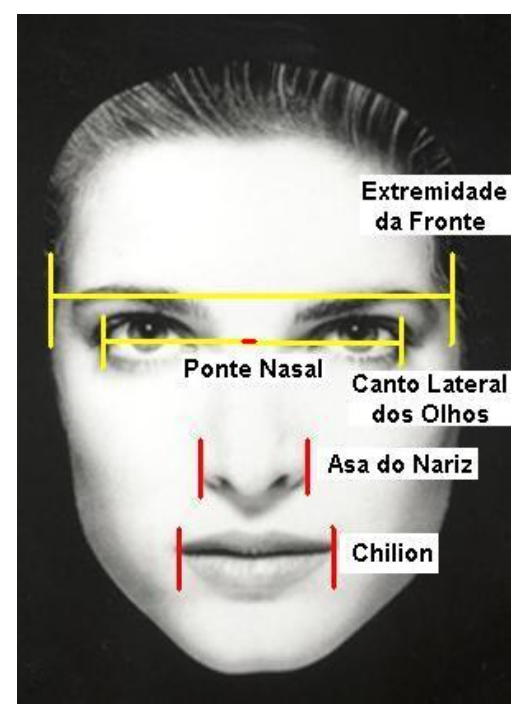

Figura 2.24: Progressão do nariz para boca; da boca para os olhos; dos olhos para a cabeça

Uma progressão de números $\Phi$ podem ser destacadas, mostrando a existência da proporção divina numa série de quatro partes. Tomando-se a largura do nariz como 1, a largura da boca é 1,618 ou $\Phi$. A próxima parte da progressão pode ser observada em relação à largura lateral dos olhos no canto externo, sendo esta mensurada em $\Phi^{2}$. Já o $\Phi^{3}$ é a largura da cabeça no tecido fino temporal (em cada lado da testa), e o recíproco do $\Phi$ é a largura entre os cantos internos dos dois olhos. Iniciando com o nariz, a boca é áurea e, logo os olhos são áureos para a boca; sendo assim os olhos são $\Phi^{2}$ para o nariz e a largura da cabeça nas têmporas é áurea para a largura dos olhos, portanto a cabeça corresponde ao $\Phi^{3}$ para o nariz, conforme mostra a Figura 2.24 (BANKER, s.d.). 
O mesmo tipo de comparação pode ser efetuada quando se pensa nos comprimentos verticais da face, isto é, das têmporas para olho, do olho para o queixo, do queixo para a parte mais inferior do nariz, e esta por sua vez para as têmporas. Quando os dentes são considerados, uma segunda série de divinas proporções aparece. Começando com as larguras dos incisivos inferiores e trabalhando-se com eles, percebe-se a existência de uma harmonia no perfil dental que emula a mesma série áurea analisada no perfil transversal da face frontal (BANKER, s.d.).

Uma série de pesquisas neste assunto tenta estabelecer as correlações existentes entre a secção divina e o campo de atuação dos pesquisadores. Dessa maneira, ortodentistas a relacionam com o perfil dental humano; cirurgiões plásticos buscam equacioná-la com a beleza, proporcionando trabalhos estéticos mais eficientes; artistas plásticos procuram interpretá-la como a beleza racional. Os resultados de alguns destes estudos revelam facetas que podem ser exploradas pela pesquisa proposta. Na sequiência, alguns aspectos mensurados são apresentados, os quais certamente contribuirão para uma melhor abordagem do problema.

\subsubsection{A Linha dos Lábios}

Em uma face relaxada, onde os dentes não estão se tocando (o maxilar inferior está na posição de descanso, mas com um pequeno espaço livre), a linha labial divide o terço inferior da face em uma Proporção Divina. O espaço entre a parte baixa do nariz e a parte baixa do queixo é dividido pela linha labial em um segmento "queixo a linha labial" (parte maior) e a um segmento "linha labial a porção inferior nasal"(parte menor). A menor e a maior parte estão em Proporção Divina como mostra a Figura 2.25, (LEVIN, s.d.).
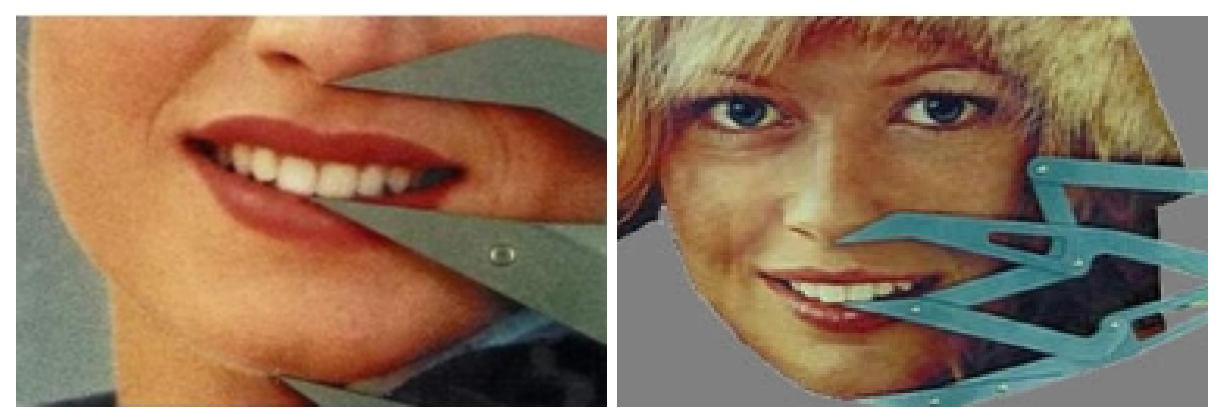

Figura 2.25: Proporção Divina no segmento queixo-nariz 


\subsubsection{Desenhos Infantis}

Os mais rústicos desenhos de faces humanas são produzidos, normalmente, por crianças; sendo caracterizados por dois traços para a composição dos olhos e uma curva para a boca sorridente circundados por um círculo que delimita a face, como mostra a Figura 2.26. Psicólogos têm procurado confirmar a importância do sorriso materno e seu efeito sobre uma criança diante das reproduções nos desenhos de faces humanas.

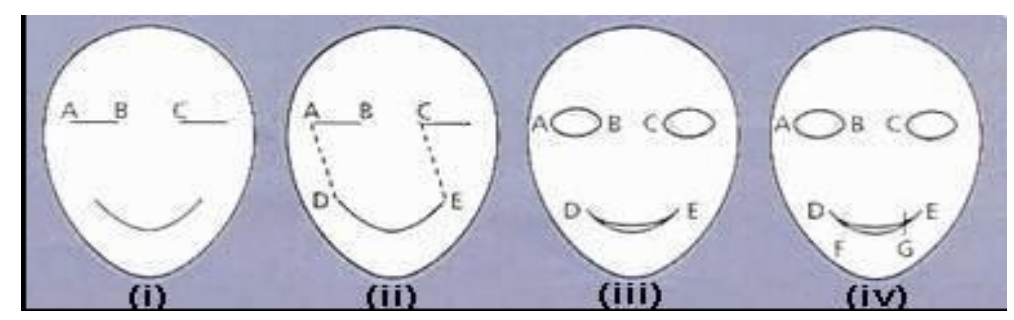

Figura 2.26: Desenhos Infantis de Faces Humanas

Os desenhos infantis possuem alguns padrões fascinantes, os quais são relevantes para o aspecto dental. Semelhantemente este fato indica a importância dos pontos finais, dos aparentemente, casuais traços como marcos estéticos. O traço representativo do olho é balizado lateralmente pelo canto externo e na outra ponta correspondente ao aspecto lateral do canto mais profundo ou o fim da bola branca ocular visível. A distância entre os dois olhos é a distância entre o "Branco dos Olhos".

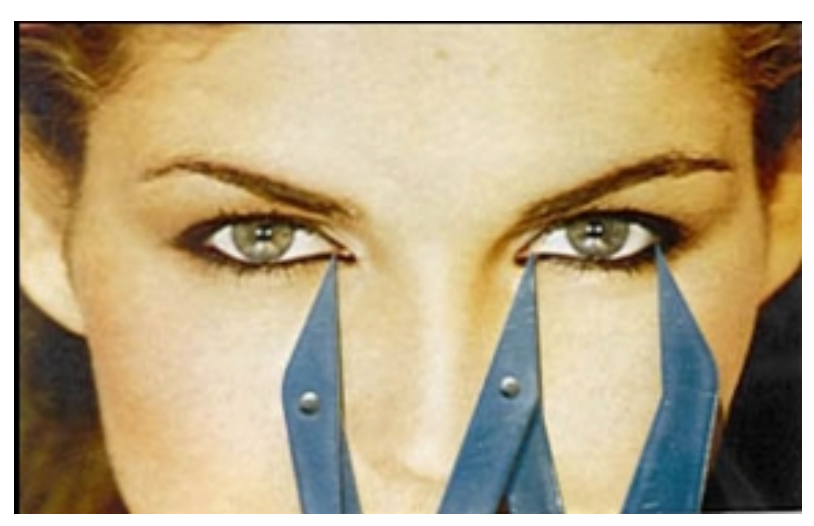

Figura 2.27: Distância entre o "Branco dos Olhos"

A distância entre o "Branco dos Olhos" está magnificamente inter-relacionada em Proporção Divina como mostra a Figura 2.27. Tal proporção pode ser percebida também na Figura 2.26 (iii), onde AB/BC estão em proporção divina (LEVIN, s.d.). 


\subsubsection{Proporções entre os Dentes e o Sorriso}

Em desenhos de crianças, a partir de uma determinada idade, os olhos-traços tornam-se círculos e os lábios são separados (Figura 2.26 (iii)). Eles mostram um novo grupo de fascinantes Proporções Divinas muito útil no estudo ortodôntico. É importante perceber que os lábios separados mostrados na Figura 2.26 (iii) não se estendem de canto a canto da boca, eles geralmente param em um ponto a certa distância dos mesmos. Portanto, existe uma área de escuridão ou neutralidade entre os dentes e o canto de uma boca sorridente, constituindo um dos mais importantes fatores para se dar o aspecto natural a uma prótese dentária.

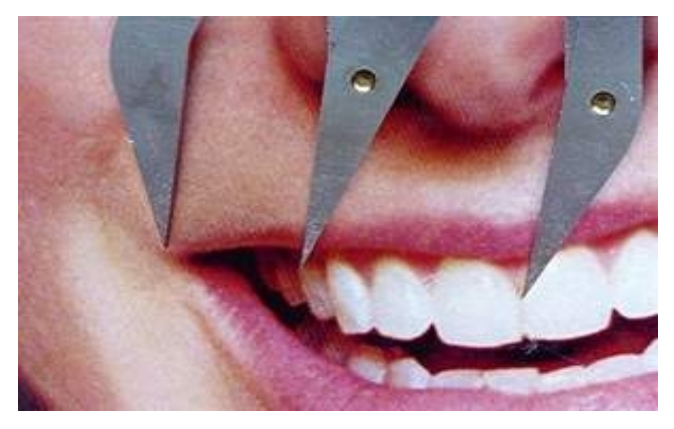

Figura 2.28: Proporção Divina do Sorriso

Na Figura 2.28, o Medidor de Proporção Divina mostra que o canto do arco divide o sorriso em uma larga parte com dentes e uma pequena parte neutra ou escura, revelando a importância deste efeito visual para a estética bucal.

\subsubsection{Proporções entre os Olhos e os Dentes}

O branco dos olhos (AB) está em Proporção Divina com o espaço entre os olhos (BC), conforme mostrado na Figura 2.26 (iv). A partir disso pode-se concluir que a largura do branco $(\mathrm{FG})$, do segmento estético anterior está em proporção áurea com o branco dos olhos $(\mathrm{AB})$, conforme se explica: por medição, nota-se que a largura dos lábios de uma boca sorridente, de um canto a outro, é igual à distância entre a ponte do nariz somado com a largura do olho (AC=DE). 
Nos Olhos:

$\frac{\text { Parte Menor }}{\text { Parte Maior }}=\frac{0.618}{1}=\frac{\text { Olho }}{\text { Ponte }}=\frac{A B}{B C}=\frac{\text { Ponte }}{\text { Olho }+ \text { Ponte }}=\frac{B C}{A C}=\frac{\text { Parte Maior }}{\text { Total }}$

No Sorriso:

$$
\frac{F G}{D E}=\frac{\text { Dentes no Sorriso }}{\text { Largura do Sorriso }}=\frac{\text { Parte Maior }}{\text { Total }}
$$

Ponte BC $=$ Dentes mostrados no Sorriso FG

$\mathrm{AC}(\mathrm{Olho}+$ Ponte $)=$ Largura do Sorriso DE

Nos Olhos e Sorriso:

$$
\frac{B C-\text { Parte Maior }}{A C-\text { Total }}=\frac{F G-\text { Parte Maior }}{D E-\text { Total }}
$$

$\mathrm{BC}($ Ponte $)=\mathrm{FG}($ Dentes no Sorriso $)$ e AC $($ Olho + Ponte $)=\mathrm{DE}($ Largura do Sorriso $)$

Portanto, AB está em Proporção Divina com o branco dos dentes, demonstrados no Sorriso (LEVIN, s.d.).

\subsubsection{Relação Dente a Dente}

A primeira relação áurea, uma das mais importantes descobertas, é a simples Proporção Divina dente a dente. O Medidor de Proporção Divina revela que a largura do incisivo central está em Proporção Divina em relação a largura do incisivo lateral. De maneira similar, observa-se que o incisivo lateral está na mesma Proporção Divina com o canino; e este, por sua vez, está com o primeiro pré-molar (LEVIN, s.d.), conforme mostra a Figura 2.29. 

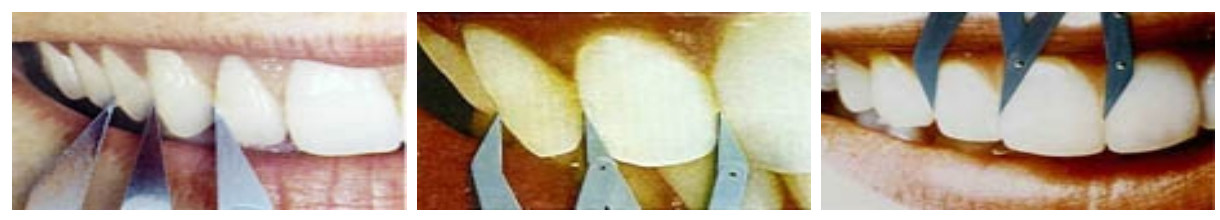

Figura 2.29: Proporção Divina Dente a Dente

\subsubsection{Outras Medidas Interessantes}

A Proporção Divina na face humana pode ser observada:

- a linha dos olhos que divide o comprimento do rosto em média e extrema razão, ou seja, em razão áurea (Figura 2.30) (CENTRO FEDERAL DE EDUCAÇÃO TECNOLÓGICA DO PARANÁ. Unidade de Ponta Grossa, 2002).

- na divisão, pela boca, da distância entre a base do nariz e do queixo (Figura 2.30).

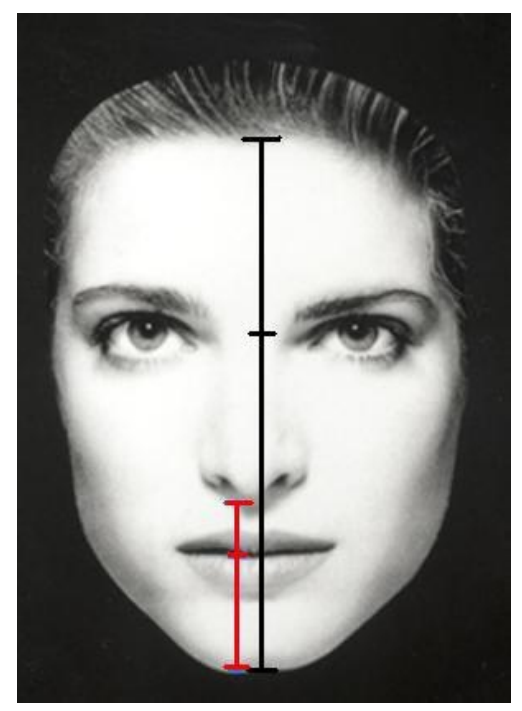

Figura 2.30: Medidas em Razão Áurea

Em muitas outras partes do corpo pode ser encontrada a divisão áurea, tais como:

- o umbigo que divide o corpo do adulto em média e extrema razão;

- no dedo médio da mão, o comprimento da falangeta é o segmento áureo do comprimento da falanginha, e este, por sua vez, é o segmento áureo do comprimento da falange (Figura 2.31); 


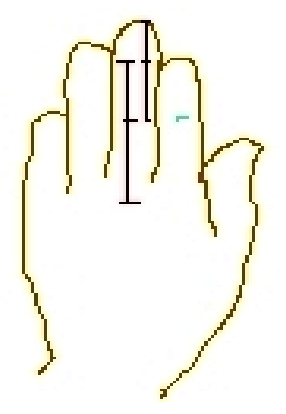

Figura 2.31: Segmentos Áureos do Dedo Médio da Mão

- a linha dos ombros que divide em média e extrema razão a distância do umbigo até o alto da cabeça;

- o punho fechado forma um polígono de cinco lados mostrado na Figura 2.32, sendo que as três falanges do dedo indicador são três termos consecutivos da secção áurea que seguem a propriedade característica da progressão contínua, na qual cada termo é a soma do precedente. Isto se reflete tal como na seqüência de Fibonacci, onde a relação entre um termo desta sucessão e o que o precede se aproxima, cada vez mais do número de ouro (SECÇÃO, s.d.).

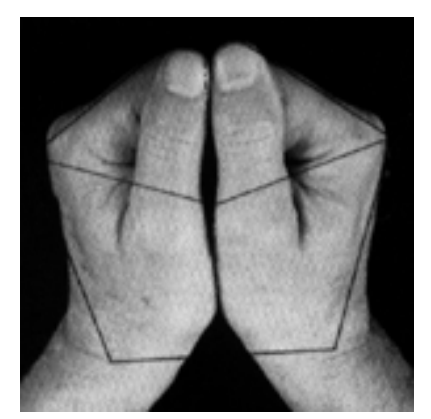

Figura 2.32: O Punho Fechado

\subsection{Estudos na Área}

Ricketts (1982) propôs a utilização da Proporção Divina, para reabilitar os segmentos da face. Este autor investigou a presença da proporção em vários segmentos ósseos, dentais e também no perfil dos tecidos moles. Utilizando-se de fotografias de dez modelos fotográficos - mulheres consideradas belas - fez a análise de segmentos formados pelos 
principais pontos faciais considerados pela ortodontia. $\mathrm{O}$ autor desta forma encontrou a presença da proporção divina entre os segmentos em 95 a $99 \%$ das belas faces.

Powell \& Humphreys (1984) fizeram uma revisão das experiências passadas e presentes das técnicas de avaliação da estética facial que poderiam ser utilizadas na cirurgia corretiva. Estes autores consideraram que a beleza facial deveria estar associada à simetria e harmonia dos segmentos individuais da face. Embora os parâmetros fossem difíceis para quantificar as linhas, os ângulos e os contornos da face, estes poderiam ser medidos e comparados estabelecendo padrões de avaliação para uma meta de beleza. Assim, fizeram uma consideração dos componentes da estética facial que atuam como moderadores, são eles: a idade, o sexo, o tipo físico, o cabelo, a raça, a simetria e as proporções.

Os trabalhos realizados com aplicação na área de ortodontia (PICCIN, 1997) mostram a existência da proporção em faces de perfil e que podem ser utilizadas para a correção ortodôntica. Na Figura 2.33 as razões constituídas entre os segmentos $\mathrm{A} / \mathrm{B},(\mathrm{A}+\mathrm{B}) / \mathrm{A}$, $\mathrm{C} / \mathrm{B},(\mathrm{B}+\mathrm{C}) / \mathrm{A},(\mathrm{A}+\mathrm{B}+\mathrm{C}) /(\mathrm{B}+\mathrm{C}),(\mathrm{A}+\mathrm{B}+\mathrm{C}) /(\mathrm{A}+\mathrm{B})$ são todas iguais a $\Phi$, ou seja, iguais à razão áurea.

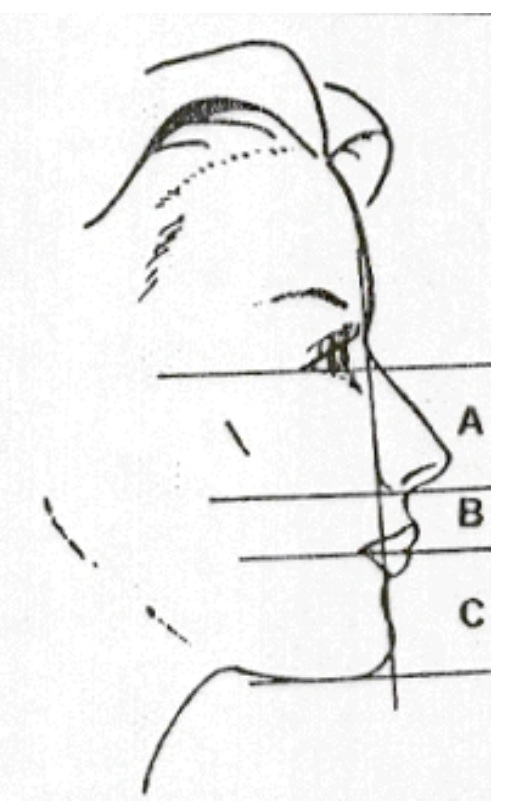

Figura 2.33: Segmentos proporcionais em uma face de perfil (Piccin, 1997) 
O cirurgião plástico Dr. Marquardt (2001) utilizando-se de uma coleção de linhas e pontos selecionados de uma máscara composta por pentágonos os quais são, relacionados em tamanho com a Proporção Áurea pode compor uma máscara áurea (Figura 2.34). Esta reflete a distância ideal entre os elementos de um rosto atraente, pois de maneira impressionante, a máscara encaixa-se perfeitamente em qualquer rosto considerado bonito, independente de raça, região ou tempo. Como os clientes de um cirurgião plástico querem se tornar mais belos, o método, fundamentalmente, aplica uma máscara proporcional à face deste para obter as principais divergências e assim corrigí-las com o bisturi.
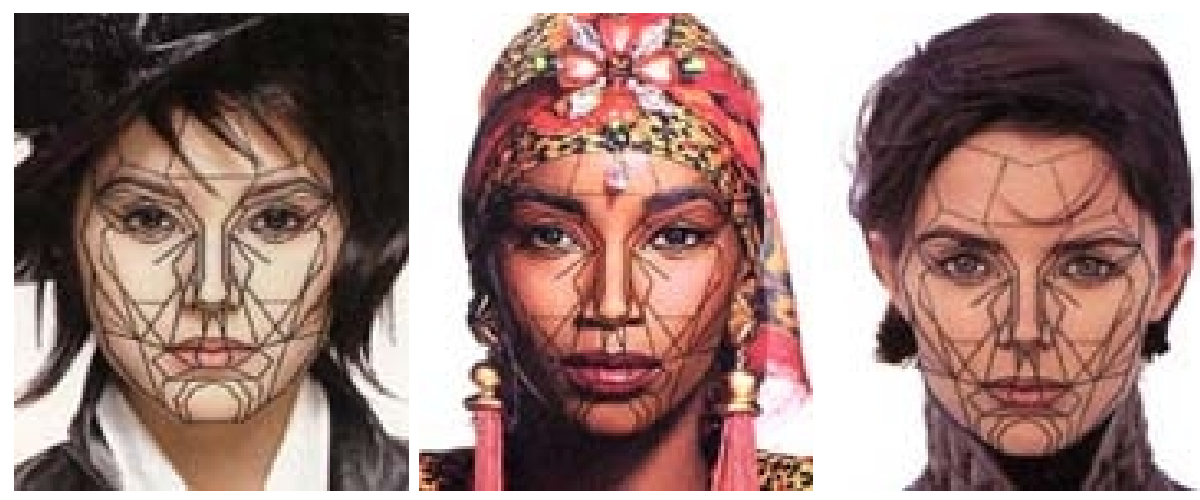

Figura 2.34: Máscara de Beleza do Dr. Marquardt

Partindo dos estudos do Dr. Marquardt, Ann McNamara e Rachel McDonnell (MCNAMARA \& MCDONNELL, s.d.), construíram uma versão da máscara de beleza ideal em três dimensões. O "software" tem a capacidade de mostrar os desvios de um rosto comum em relação à máscara nos três eixos, conforme pode ser visto na Figura 2.35.

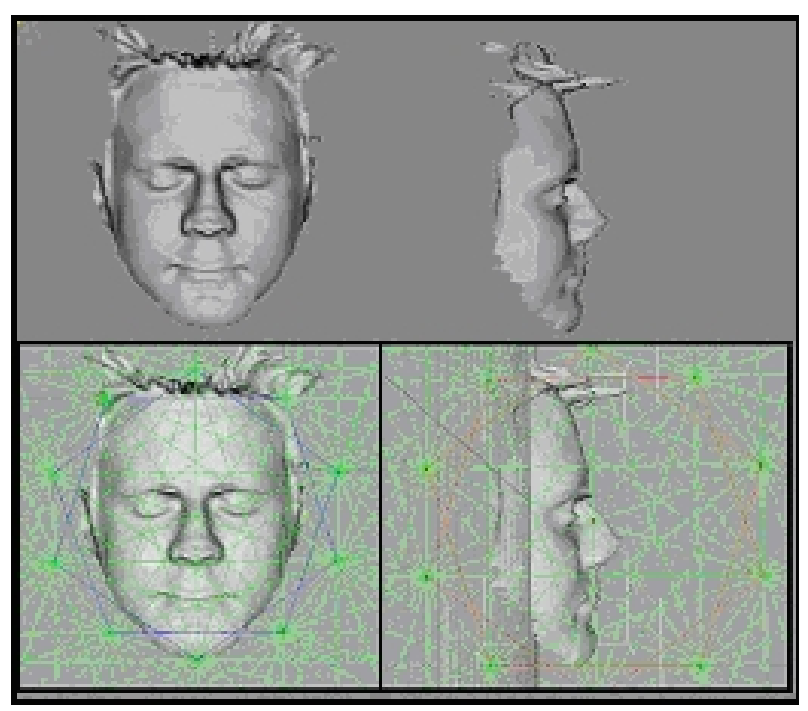

Figura 2.35: Estudos de Ann McNamara e Rachel McDonnell 
Os professores do Departamento de Matemática da Drexel University, coordenados pela Prof. Dra. Suzanne Alejandre (2003), têm realizado práticas de medidas faciais, especialmente utilizando o retângulo áureo com alunos, na tentativa do ensinamento do número irracional $\Phi$ e das vastas possibilidades de pesquisas ofertadas pela conjunção do número com a estrutura humanóide.

Com o objetivo de quantificar os padrões estéticos e aplicá-los racionalmente na odontologia, o Dr. Osmir Batista de Oliveira Junior, professor da disciplina de Dentística da Faculdade de Odontologia de Araraquara - UNESP, realizou uma pesquisa científica que mostra a importância da Proporção Divina na estética humana (OLIVEIRA JR., 2000). Participaram da pesquisa 60 voluntários de ambos sexos, com faixa etária de 20 a 30 anos, dos quais foram tiradas duas fotografias (face e sorriso) à distâncias padronizadas. As fotografias estavam sob o mesmo padrão de luminosidade, regulagem de abertura e de velocidade da câmara fotográfica, totalizando 120 imagens. Estas foram inicialmente pareadas de 1 a 60 para face e de 61 a 120 para sorrisos e, a seguir passaram por análises estéticas.

As 120 fotografias foram misturadas e apresentadas a 20 examinadores que classificaram-nas em bonitas e não bonitas, segundo critérios pessoais. Os resultados obtidos tiveram médias percentuais tabuladas e foram transcritos para uma tabela apropriada, na qual se observava a beleza percebida pelos examinadores tanto para a face, quanto para o sorriso dos voluntários.

Em seguida, fixaram folhas de papel vegetal previamente recortadas sobre as fotografias, realizando-se o traçado e as mensurações de 8 normas de simetria e proporcionalidade, algumas destas já descritas no presente trabalho: N1 - proporção áurea vertical da face; N2 - proporção áurea horizontal de face; N3 - linha interpupilar; N4 - linha mediana; N5 - plano incisal; N6 - proporção divina dos dentes anteriores/superiores; N7 - linha do sorriso; e, N8 - relação interdental. As proporções encontradas foram classificadas em: confirmam e não confirmam a norma estética.

Após análise, as fotografias foram ordenadas dos mais bonitos para os menos bonitos, e os resultados da correspondência entre percepção da beleza e presença de normas estéticas foram calculados percentualmente para os voluntários bonitos e não bonitos. Através da freqüência percentual das fotografias, ordenadas percebeu-se deste modo, que os voluntários classificados como mais belos apresentaram uma confirmação de presença das normas estéticas em 73,33 \% das avaliações, enquanto que os voluntários percebidos como não bonitos confirmaram as regras estéticas em apenas 38,33\% dos casos.

Sendo R1 - resultado encontrado da proporção áurea vertical da face; R2 - resultado encontrado da proporção áurea horizontal de face; R3 - resultado encontrado da linha in- 
terpupilar; R4 - resultado encontrado da linha mediana; R5 - resultado do plano incisal; R6 - resultado encontrado da proporção divina dos dentes anteriores/superiores; R7 - resultado encontrado da linha do sorriso; e, R8 - resultado encontrado da relação interdental, temos que a frequiência das diferentes normas estéticas nos grupos mais bonitos e menos bonitos inferiu que os fatores mais significativos para os percebidos como mais bonitos são na ordem de influência: R2 e R7 (86,6 \%), R5 (80 \%), R1, R4 e R8 (76,6 \%), R3 $(63,3 \%)$ e por último R6 (43,3\%). E considerando os voluntários classificados como menos bonitos a freqüência de confirmação, as normas obtidas foram as seguintes: R3 e R4 (63,3\%), R7 (43,3\%), R2 (40 \%), R1 (33,3\%), R8 (20\%), R5 (16,6 \%) e R6 (13,3 $\%)$. As Figuras 2.36 e 2.37 apresentam os gráficos com os resultados da confirmação das normas estéticas no grupo mais bonitos e menos bonito, respectivamente.

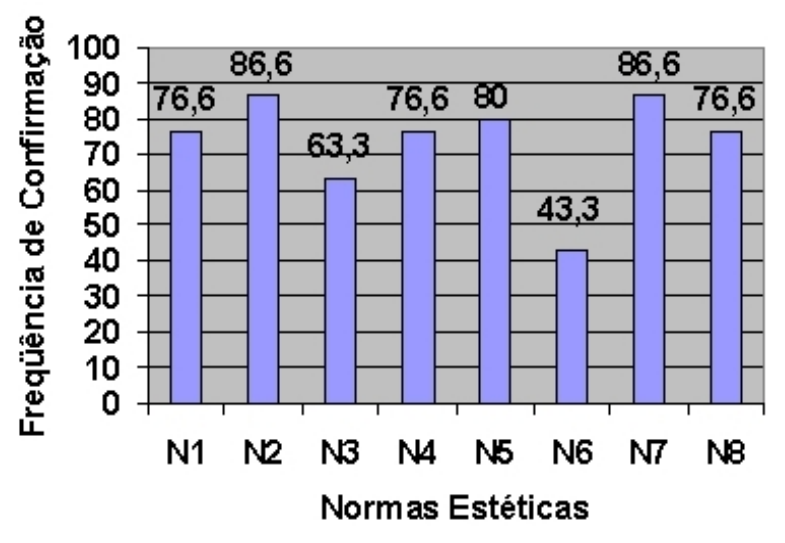

Figura 2.36: Confirmação das Normas Estéticas no grupo mais bonitos

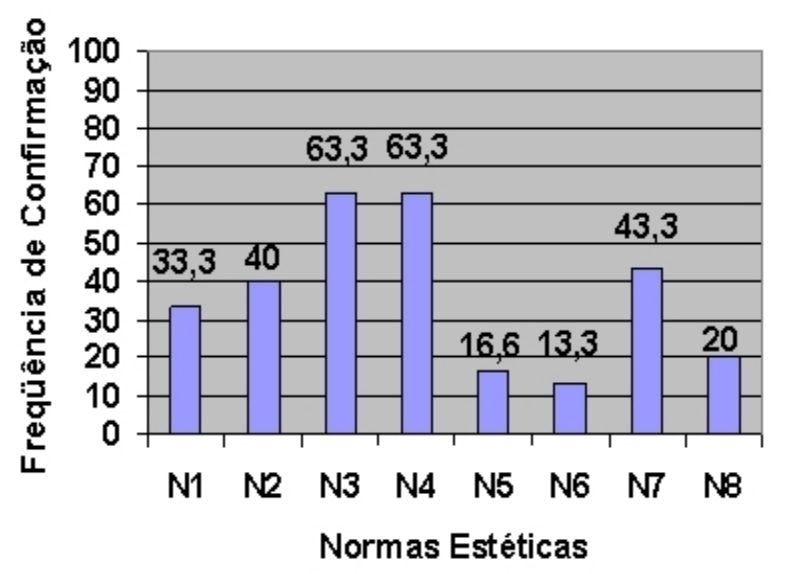

Figura 2.37: Confirmação das Normas Estéticas no grupo menos bonitos

Conforme a explanação deste capítulo, a Proporção Divina mais uma vez mostra-se presente em praticamente tudo na Natureza; sendo explorada por áreas diversas como a pintura, a escultura, a arquitetura, o desenho gráfico, a ortodontia, a cirurgia plástica. 


$\frac{-1}{3}$

\section{Conjuntos Fuzzy e Lógica Fuzzy}

\subsection{Introdução}

A reprodução de características inteligentes em máquinas construídas pelo homem é um dos objetivos mais atraentes para a comunidade científica e tecnológica. Muitos paradigmas simbólicos de aprendizagem surgiram, e muitos se desenvolveram, tais como os métodos computacionais poderosos, incluindo a aquisição indutiva de conceitos, os sistemas classificadores e a aprendizagem baseada em explicações.

Um conjunto de ferramentas analíticas, conhecidas coletivamente como Inteligência Artificial (IA), têm sido utilizadas para solucionar problemas relacionados à aprendizagem de máquinas, permitindo a resolução de problemas anteriormente difíceis ou impossíveis de serem tratados.

A característica marcante da Inteligência Artificial está no objetivo primário, alcançar tratabilidade, robustez, baixo custo e um alto coeficiente de inteligência de máquina, através de uma exploração da tolerância à imprecisão e à incerteza. Busca-se neste contexto uma solução aproximada para um problema formulado imprecisamente.

Um exemplo simples é o estacionar um carro. Primeiramente, estaciona-se um carro com relativa facilidade porque a posição final e a orientação do carro não são especifica- 
dos precisamente. Caso o fossem, o problema seria praticamente insolúvel para os seres humanos. Em contradição, quando o problema é formulado imprecisamente torna-se difícil de resolvê-lo pelos métodos computacionais convencionais, pois estes não tratam e nem exploram a tolerância à imprecisão.

O que este exemplo ilustra é que, em geral, uma precisão alta acarreta um alto custo. O desafio é, portanto, explorar a tolerância à imprecisão pela busca de novos métodos de computação que levem a uma solução aceitável a um baixo custo. Pela sua própria natureza, a Inteligência Artificial é muito mais próxima ao raciocínio humano do que os modos tradicionais de computação.

Os principais constituintes da Inteligência Artificial são as Redes Neurais Artificiais (preocupam principalmente com a teoria da aprendizagem), a Lógica "Fuzzy" ou Lógica Nebulosa (com a imprecisão e o raciocínio aproximado), o Raciocínio Probabilístico (ou também, Algoritmos Genéticos, com o gerenciamento da incerteza) e os Sistemas Caóticos.

A Lógica "Fuzzy" é a lógica que suporta os modos de raciocínio aproximados, ao invés de exatos. O Controle "fuzzy" e a Modelagem de Sistemas são técnicas para o tratamento de informações qualitativas de forma rigorosa.

Derivada do conceito de conjuntos "fuzzy", a lógica "fuzzy" constitui a base para o desenvolvimento de métodos e algoritmos de modelagem e controle de processos, permite também a redução da complexidade de projeto e implementação tornando-se a solução para problemas de controle até então intratáveis por técnicas clássicas. Ela difere dos sistemas lógicos em suas características e seus detalhes, assim, o raciocínio exato corresponde a um caso limite do raciocínio aproximado, sendo interpretado como um processo de composição de relações nebulosas. A melhor ferramenta para modelar o raciocínio humano que pode ser considerada é a lógica "fuzzy", a qual é aproximada e parcial em sua essência.

A teoria dos conjuntos "fuzzy" e a lógica "fuzzy" objetivam modelar os modos de representação e de raciocínio imprecisos, possuidores de um papel essencial na tomada de decisões racionais em ambientes de imprecisão e incerteza. A diversificação das tecnologias advindas da lógica "fuzzy" tem permitido a sua aplicação em diversas áreas de conhecimento, como exemplo, o Processamento Digital de Imagens.

No desenvolver deste projeto utilizou-se a lógica "fuzzy" em razão das suas qualidades em manusear informações qualitativas e imprecisas de uma maneira rigorosa; resultando assim em um classificador "fuzzy" de sistema, o qual poderá propiciar um controle mais aguçado, e um desempenho estável. 


\subsection{Histórico}

O conceito de Conjunto "Fuzzy" foi introduzido em 1965, por Lotfi A. Zadeh da Universidade da Califórnia, Berkeley. É atribuído a ele o reconhecimento como grande colaborador do Controle Moderno. Em meados da década de 60, Zadeh observou a incapacidade dos recursos tecnológicos disponíveis para automatizar as atividades relacionadas aos problemas de natureza industrial, biológica ou química, estes compreendiam situações ambíguas, não passíveis de processamento através da lógica computacional fundamentada na lógica booleana. Procurando solucionar esta incapacidade, Zadeh publicou um artigo na revista "Information and Control", no qual resumia os conceitos dos Conjuntos "Fuzzy", e assim, revolucionou o assunto com a criação de Sistemas "Fuzzy" (ZADEH, 1965).

Em 1974, o Prof. Mamdani, do Queen Mary College da Universidade de Londres, após inúmeras tentativas frustradas em controlar uma máquina à vapor com tipos distintos de controladores incluindo o PID (Proporcional Integral e Derivativo), conseguiu controlá-la através da aplicação do raciocínio "Fuzzy". Este alavancou muitas outras aplicações; como em 1980, no controle "Fuzzy" de operação de um forno de cimento.

Em seguida, outras aplicações vieram, destacando-se, os controladores "Fuzzy" de plantas nucleares, refinarias, processos biológicos e químicos, trocadores de calor, máquinas diesel, tratamentos de água e sistemas de operação automática de trens.

Estimulados pelo desenvolvimento e pelas enormes possibilidades práticas de aplicações, os estudos sobre Sistemas "Fuzzy" e o controle de processos cresceram rapidamente, culminando com a criação em 1984, da Sociedade Internacional de Sistemas “Fuzzy”. Esta foi constituída por pesquisadores dos países mais avançados tecnologicamente.

Os Sistemas "Fuzzy" foram amplamente ignorados nos Estados Unidos devido a associação com a inteligência artificial, um campo que se obscurecia, resultando numa falta de credibilidade por parte da indústria. A propósito, mais de 30\% dos artigos até hoje publicados são de origem japonesa, os quais tiveram influência devido ao interesse demonstrado por Seiji Yasunobu e Soji Miyamoto da Hitachi, que em 1985, apresentaram simulações demonstrando a superioridade de Sistemas de Controle "Fuzzy" para a estrada de ferro de Sendai. As idéias foram adotadas e os Sistemas "Fuzzy" foram utilizados para controle de aceleração, frenagem e parada; favorecendo a inauguração da linha em 1987. 
Outro evento em 1987 que ajudou a promover o interesse em Sistemas "Fuzzy" foi durante um encontro internacional de pesquisadores de "Fuzzy" em Tokyo, Japão. Takeshi Yamakawa demostrou o uso do Controle "Fuzzy" através de conjuntos de simples "chips" "fuzzy" dedicados em um experimento de um pêndulo invertido - um problema clássico de controle em que um veículo tenta manter um poste montado no seu topo por uma dobradiça vertical com movimentos de ida e volta.

Observadores ficaram impressionados com a demonstração, e também com os experimentos de Yamakawa (a montagem de um copo contendo água ou até mesmo de um rato vivo no topo de pêndulo, sendo que o sistema manteve estabilidade em ambos os casos). Este foi organizando seu próprio laboratório de pesquisas de Sistemas "Fuzzy", ajudando a exploração de suas patentes no campo de pesquisa.

Seguindo as demonstrações, japoneses interessaram-se pelos sistemas "fuzzy", desenvolvendo tanto aplicações industriais como aplicações para consumo. Em 1988, criaram o Laboratório Internacional de Engenharia "Fuzzy"(LIFE), uma cooperativa que compreendia 48 companhias para pesquisa em Sistemas "Fuzzy” (LÓGICA, s.d.).

Em 1995 Maytag introduziu a máquina de lavar pratos "inteligente", baseando-se em um Controlador "Fuzzy" e um "one-stop sensing module", os quais combinam um termistor para medida da temperatura, um sensor condutivo para medir o nível de detergente através dos íons presentes na água, um sensor de turvação que difunde a medida e transmite luz para medir a sujeira na lavagem e um sensor magnético para ler a taxa de giro. $\mathrm{O}$ sistema determina uma otimização no ciclo de lavagem para qualquer carga e obtemos os melhores resultados com o mínimo de energia, detergente e água (LÓGICA, s.d.).

O desenvolvimento de técnicas de Inteligência Artificial nos últimos anos ocupa posição de destaque em pesquisas na área de controle de processos industriais e, aos poucos, começam a ser implantadas em plantas industriais com sucesso. Dentre as técnicas mais utilizadas além do Controle "Fuzzy", pode-se destacar as redes neurais aplicadas aos sistemas de controle, que estão atualmente em tamanha evidência que os japoneses as consideram como duas das mais promissoras técnicas para o século XXI. 


\subsection{Conjuntos "Fuzzy"}

\subsubsection{Introdução}

Um Conjunto "Fuzzy" é descrito por uma função que designa graus de pertinência entre zero e um aos seus membros. Um elemento que tenha grau de pertinência igual a zero não pertence ao conjunto. Já o grau de pertinência igual a um, indica que o elemento pertence totalmente ao conjunto, e graus de pertinência entre zero e um significam que o elemento pertence parcialmente ao conjunto. Como exemplo, consideremos um conjunto de pessoas de meia idade (a Tabela 3.1 ilustra esse conjunto). Logo, uma pessoa de 50 anos pertence ao conjunto com um grau de pertinência de 0,7 ou $70 \%$.

\begin{tabular}{|l|c|c|c|c|c|c|c|}
\hline Membros (idades) & 30 & 35 & 40 & 45 & 50 & 55 & 60 \\
\hline Graus de Pertinência & 0,0 & 0,3 & 1,0 & 1,0 & 0,7 & 0,4 & 0,0 \\
\hline
\end{tabular}

Tabela 3.1: Conjunto das pessoas de meia idade

\subsubsection{Conceito}

O conceito de conjunto "fuzzy" é o principal pilar da teoria da lógica "fuzzy". $\mathrm{Na}$ teoria clássica há uma clara distinção entre os elementos que pertencem e os que não fazem parte de um conjunto. O conjunto "fuzzy" permite representar conceitos vagos expressos na linguagem natural. A representação deste conjunto depende não somente do conceito, mas também do contexto no qual é utilizado (KLIR \& YUAN, 1995). Por exemplo, a temperatura alta no contexto de clima e de reator nuclear são representadas por conjuntos "fuzzy" diferentes.

\subsection{Lógica "Fuzzy"}

Uma das características da Lógica Clássica é o axioma do Terceiro Excluído, isto é, não existe alternativa para um valor verdade além do par verdadeiro ou falso. Ao lidar com problemas do mundo real, no entanto, vemos que o conhecimento disponível não é nem absolutamente verdadeiro nem absolutamente falso, podendo ser paradoxais, incertos, 
desconhecidos, indeterminados, verdadeiros em geral, verdadeiros com uma certa probabilidade, etc. Para estender a Lógica Clássica de maneira que permita o tratamento deste tipo de conhecimento é necessário a alteração do conjunto de valores, o verdadeiro ou falso. Dentre os formalismos propostos para alterar este conjunto de valores, encontra-se a Lógica "Fuzzy".

A Lógica "Fuzzy" é baseada na teoria dos Conjuntos "Fuzzy" para sua representação. Neste tipo de lógica há a presença de uma série de elementos, destes pode-se citar as Variáveis Lingüísticas, o Raciocínio "Fuzzy" e o Sistema de Inferência "Fuzzy". Também na literatura são encontrados vários métodos de inferência utilizando o paradigma "fuzzy".

\subsubsection{Variáveis Lingüísticas}

Na lógica "fuzzy", o valor verdade de uma proposição pode ser um subconjunto "fuzzy" de qualquer conjunto parcialmente ordenado, ao contrário dos sistemas lógicos binários, onde o valor verdade só pode assumir dois valores: verdadeiro (1) ou falso (0).

Nos sistemas lógicos multi-valorados, o valor verdade de uma proposição pode ser um elemento de um conjunto finito num intervalo ou uma álgebra booleana. Na lógica "fuzzy”, os valores verdade são expressos lingüísticamente (frio, muito frio, gelado, quente, muito quente), sendo cada termo lingüístico interpretado como um subconjunto "fuzzy" do intervalo unitário.

Nos sistemas lógicos binários, os predicados são exatos (par, maior que) ao passo que na lógica "fuzzy" os predicados são nebulosos (alto, baixo). Quanto ao modificador nos sistemas lógicos clássicos, o mais utilizado é a negação, enquanto que na lógica "fuzzy" uma variedade de modificadores de predicados são possíveis (muito, mais ou menos, pouco, muito pouco). Os modificadores são essenciais na geração de variáveis lingüísticas ou variáveis "fuzzy" (tais como: muito alto, mais ou menos perto, etc.), os quais são a princípio, elementos simbólicos utilizados para descrever o conhecimento.

Sabe-se que uma variável lingüística tem a seguinte estrutura:

- nome da variável;

- predicados que identificam lingüisticamente, em diferentes regiões do universo;

- universo; 
- função de pertinência para cada conjunto "fuzzy" designado por um predicado;

- função que associa um determinado valor ao seu significado.

Portanto, a variável lingüística pode ser caracterizada por uma quíntupla (x, T(x), U, $\mathrm{G}, \mathrm{M}$ ) na qual x é o nome da variável; $\mathrm{T}(\mathrm{x})$ é o conjunto de termos de $\mathrm{x}$ e é também o conjunto de nomes dos valores lingüísticos de x no qual cada valor é um número "fuzzy" definido em $U$; $G$ é a regra sintática para gerar o nome dos valores de $\mathrm{x}$; e $\mathrm{M}$ é a regra semântica para associar cada valor com seu significado (Lee, 1990). Por exemplo, se a velocidade for interpretada como uma variável lingüística, logo seus conjuntos de termos $\mathrm{T}$ (velocidade) poderiam ser:

$\mathrm{T}($ velocidade $)=\{$ lenta, moderada, rápida, muito lenta, mais ou menos rápida... $\}$

Cada termo em T(velocidade) é caracterizado por um conjunto "fuzzy" no universo de discurso $\mathrm{U}=[0,150]$. O termo lento pode ser interpretado como a velocidade abaixo de $60 \mathrm{Km} / \mathrm{h}$, o médio como a velocidade em torno de $80 \mathrm{Km} / \mathrm{h}$ e o rápido como a velocidade acima de $120 \mathrm{Km} / \mathrm{h}$. Estes termos podem ser caracterizados como o conjunto "fuzzy" no qual as funções de pertinências são evidenciadas na figura 2.1.

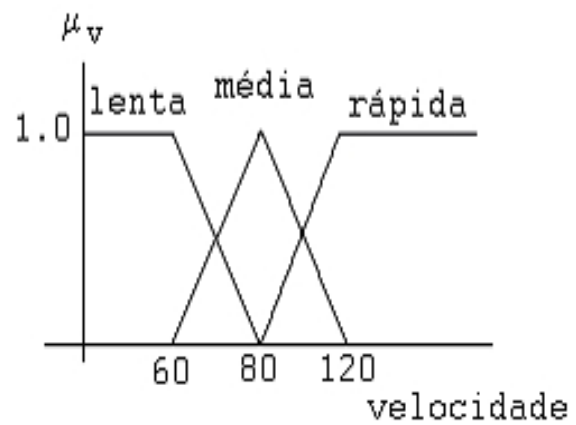

Figura 3.1: Funções de Pertinência para Velocidade

\subsubsection{Raciocínio "Fuzzy"}

Uma regra "fuzzy" ou proposição "fuzzy" relaciona variáveis "fuzzy", e cada uma delas está associada a um dos seus predicados. Estas variáveis são conectadas através de operadores lógicos como: e, ou, então, outro. 
Um algoritmo de controle é constituído por um conjunto de regras "fuzzy" que são declarações condicionais ou incondicionais, envolvendo relações entre entradas e saídas. Por exemplo, um sistema que utiliza um controlador baseado em lógica "fuzzy", com duas entradas e uma saída apresenta regras de controle "fuzzy" do tipo:

Se x é POUCO POSITIVO e y é ZERO, então z é POSITIVO GRANDE.

As variáveis "fuzzy" $\mathrm{x}, \mathrm{y}$ e $\mathrm{z}$ associadas, respectivamente aos predicados POUCO POSITIVO, ZERO e POSITIVO GRANDE, estão relacionadas através dos conectivos e e então. Para um controlador "fuzzy" de duas entradas e uma saída, com n-regras, tem-se como i-ésima regra:

$$
R_{i}: \text { Se } x \text { é } A_{i} \text { e } y \text { é } B_{i} \text {, então } z \text { é } C_{i}
$$

onde x e y são as variáveis linguiísticas de entrada e z é a saída. Considerando que, $A_{i}$, $B_{i}$ e $C_{i}$ são predicados lingüísticos das variáveis lingüísticas $\mathrm{x}, \mathrm{y}$ e $\mathrm{z}$ nos universos $\mathrm{U}, \mathrm{V}$ e $\mathrm{W}$, respectivamente, com $\mathrm{i}=1, \ldots, \mathrm{n}$.

Em um controlador "fuzzy" cada regra de controle está associada a uma relação "fuzzy" gerada por ela. O comportamento do sistema como um todo será caracterizado pelo conjunto das relações "fuzzy".

\subsubsection{Modelos "Fuzzy" (Sistema de Inferência "Fuzzy")}

O sistema de inferência "fuzzy" (FIS) é um sistema que utiliza a teoria dos conjuntos "fuzzy” para mapear entradas (características) em saídas (classes) (Knapp, 1996).

\subsubsection{Saída do Modelo "Fuzzy"}

A saída de um modelo "fuzzy" é obtida através de seis passos (Knapp, 1996):

- determinação de um conjunto de regras "fuzzy” (criação das regras);

- "fuzzificação" das entradas usando as funções de pertinência;

- combinação das entradas fuzzificadas em cada regra "fuzzy" para estabelecer a ativação da regra; 
- cálculo da parte consequente da regra;

- combinação das partes consequentes de todas as regras para obter a distribuição da saída;

- “desfuzzificação” da saída.

\subsubsection{Criação da Regra "Fuzzy"}

As regras "fuzzy" descrevem como o FIS deve realizar a decisão de classificação ou de controle. São escritas na seguinte forma:

SE (entrada 1)... E/OU (entrada 2)...ENTÃO (saída)

\subsubsection{Fuzzificação}

A etapa de "fuzzificação" mapeia a entrada (ou característica) entre valores de 0 a 1 , através das funções de pertinência. As funções mais utilizadas encontra-se descritas a seguir:

- Triangular: é especificada por três parâmetros a,b,c, a qual determina a coordenada $\mathrm{x}$ dos três cantos do triângulo (fig. 2.2(a)).

$$
\text { Triângulo(x;a,b,c) }=\max (0, \min [(x-a) /(b-a),(c-x) /(c-b)])
$$

- Trapezoidal: é especificada por quatro parâmetros a,b,c,d (fig. 2.2(b)).

$$
\operatorname{Trap}(x ; a, b, c, d)=\max (0, \min [(x-a) /(b-a), 1,(d-x) /(d-c)])
$$

- Gaussiana: é especificada por dois parâmetros s,c (fig. 2.2(c)).

$$
\operatorname{Gaussiana}(\mathrm{x} ; \mathrm{s}, \mathrm{c})=\exp -(\mathrm{x}-\mathrm{c}) / \mathrm{s} 2
$$

- Sino: é especificada por três parâmetros a,b,c (fig.2.2(d)).

$$
\operatorname{Sino}(x ; a, b, c)=1 /(1+[(x-c) / a] 2 b)
$$

- Sigmoidal: é especificada por dois parâmentros a,c (fig. 2.2(e)).

$$
\operatorname{Sig}(\mathrm{x} ; \mathrm{a}, \mathrm{c})=1 /(1+\exp [-\mathrm{a}(\mathrm{x}-\mathrm{c})])
$$




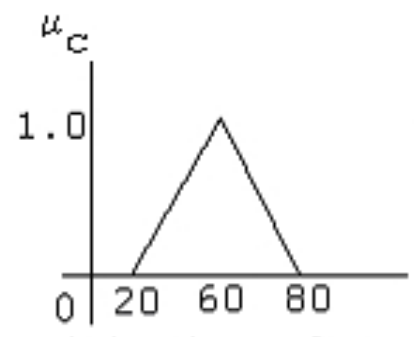

(a) triangular $(x ; 20,60,80)$

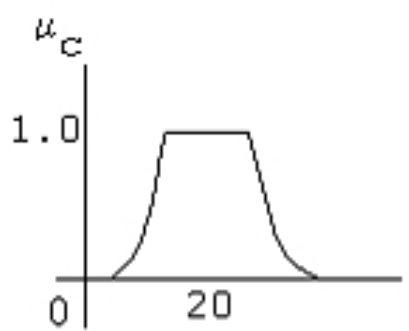

(d) sino $(\mathrm{x} ; 20,4,5)$

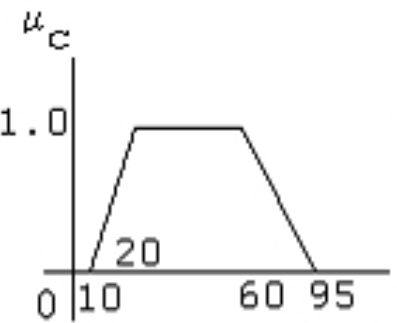

(b)trapezoidal

$(10,20,60,95)$

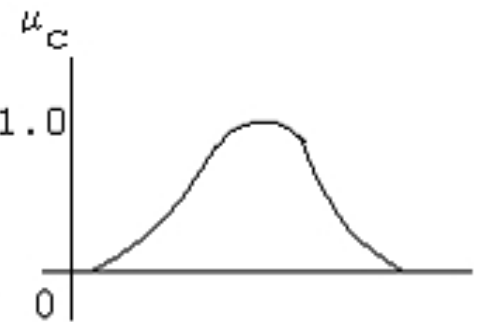

(c) gaussiana

$(x ; 20,50)$

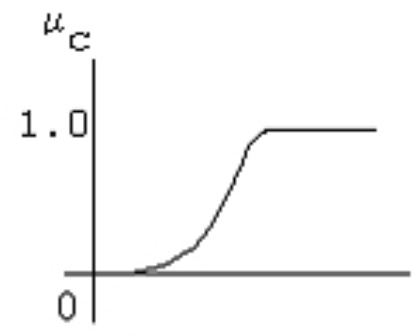

(e)sigmoidal

Figura 3.2: Funções utilizadas para "fuzzificação": (a) função triangular; (b) função trapezoidal; (c) função gaussiana; (d) função sino e (e) função sigmoidal.

\subsubsection{Desfuzzificação}

Em muitos casos é desejável que a saída do sistema não seja "fuzzy", e sim uma saída definida. A etapa de "desfuzzificação" mapeia a saída "fuzzy" em um valor definido. Algumas estratégias de "desfuzzificação" são (FRANÇA, 1999):

- método do máximo critério (MAX): O máximo critério encontra o ponto, no qual a distribuição de saída possui o seu primeiro valor de máximo (Figura 2.3);

- método da média dos máximos (MOM): O MOM encontra o valor médio, onde a saída possui seus máximos valores. Isto pode ser computado como na figura 2.3. Sendo,

$$
z_{0}=\sum\left(w_{j} / l\right)
$$

onde $w_{j}$ são os valores no qual a função de pertinência possui máximos valores e $l$ é o número de valores máximos encontrados. 
- método de centro de massa (COA): É largamente usado. Esta estratégia procura pelo centro de gravidade da distribuição de saída "fuzzy" (Figura 2.3)(Lee, 1990).

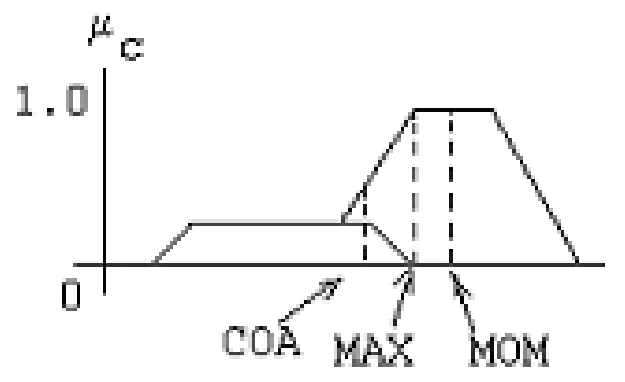

Figura 3.3: Estratégias de "desfuzzificação". Método do máximo critério (MAX). Método da média dos máximos (MOM). Método do centro de máximo (COA). 


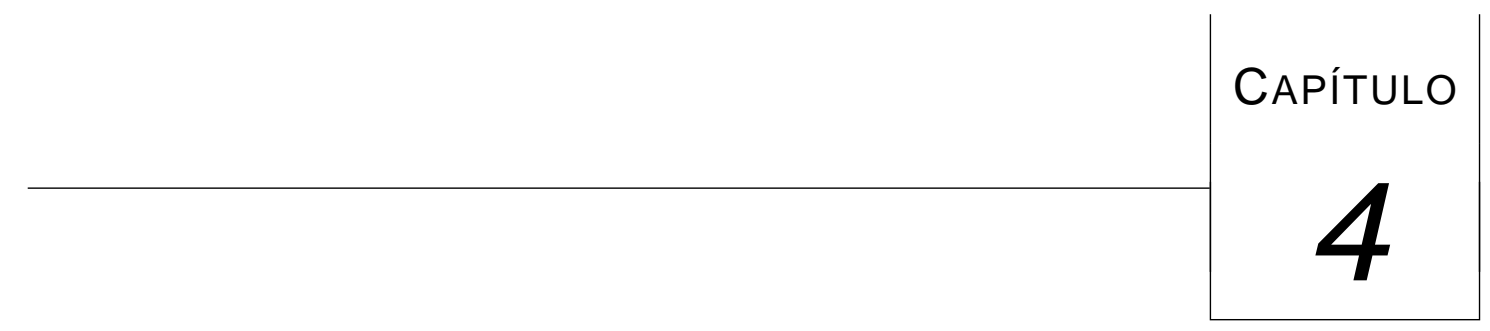

Metodologia

\subsection{Introdução}

Um foco recente de pesquisa na área de visão computacional consiste no processamento e na análise da face humana em imagens digitais. Elemento fundamental no processo de comunicação visual, a face humana é o principal atributo anatomo-fisiológico através do qual as pessoas são reconhecidas visualmente umas pelas outras. Este fato sugere que o desenvolvimento de sistemas automáticos de detecção, rastreamento e reconhecimento de faces venha oferecer facilidades em aplicações, tais como autenticação de usuários, monitoramento de ambientes, controles de acesso e de vigilância.

Nesse sentido com o emprego de Lógica "Fuzzy" e de técnicas de Processamento de Imagens investigamos as relações de proporcionalidades das faces humanas, tendo como base a Proporção Divina.

A investigação biométrica de proporções em faces humanas, motivo deste trabalho, foi implementada utilizando-se o "software" MATLAB ("MATrix LABoratory"). Essa ferramenta é concebida como um "ambiente integrado de modelagem de sistemas e algoritmos, ideal para implementação de projetos complexos, e por essa razão vem sendo 
adotado como ferramenta de desenvolvimento padrão pelas principais universidades e empresas no Brasil e no mundo" (MATSUMOTO, 2001).

O MATLAB é o núcleo de um ambiente de computação numérica fundamentado em matrizes que integram as funções de tratamento numérico de alta performance, os sofisticados recursos de geração de gráficos para visualização de dados, e a poderosa linguagem de programação de alto nível. Além disso, o "software" é dotado de pacotes de rotinas implementadas, semi-implementadas e simulações desenvolvidas, especificamente, para várias áreas do conhecimento científico-exato. Esses pacotes são os chamados "Toolboxes".

Dadas as facilidades obtidas dos “Toolboxes" de Processamento de Imagens e Lógica "Fuzzy", todo o algoritmo de investigação biométrica desenvolvido nesta pesquisa foi implementado no MATLAB.

\subsection{O Algoritmo}

O algoritmo de investigação biométrica de proporções em faces humanas desenvolvido possui cinco etapas bem definidas, conforme a Figura 4.1.

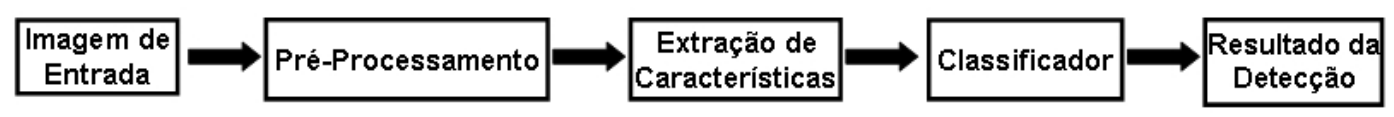

Figura 4.1: Etapas do Algoritmo

A partir da imagem de entrada é realizado um pré-processamento visando a diminuição de ruídos e a detecção de bordas. Com a imagem binarizada realiza-se a mensuração dos segmentos e retângulos áureos na face. Os resultados obtidos desta investigação biométrica passam pela etapa de classificação através de um sistema de inferência "fuzzy". Finalmente, o algoritmo define se a imagem de entrada é face ou não-face.

\subsubsection{Aquisição de Imagem}

As imagens de entrada para o algoritmo foram divididas em dois bancos de imagens que serão aqui denominados de banco de imagens de treinamento e banco de imagens de teste, sendo que cada um destes bancos é constituído de 100 imagens. 
É importante ressaltar que o banco de imagens de treinamento foi retirado do banco de imagens do Departamento de Psicologia da Universidade de Stirling (PICS, s.d.) e o banco de imagens de teste de alguns "sites" disponíveis na Internet.

As imagens contidas nesses dois bancos são imagens de faces frontais com as expressões: neutra, falando e sorrindo, observando-se também uma razoável condição de iluminação e resolução. Além disso, o banco de imagens de teste possui 10 imagens que não contém face, ou seja, imagens denominadas não-face.

Todas as imagens utilizadas no algoritmo estão em nível de cinza e possuem um resolução dimensional de aproximadamente 274 pixels de largura por 310 pixels de altura.

É certo que há restrição básica quanto à qualidade das imagens, ou seja, quanto a luminosidade, brilho e tonalidade. Nesta questão, as dificuldades geralmente são o tamanho das faces humanas nas imagens (faces de pequena dimensão não são apropriadas) e os fatores de obliteração (faces dotadas de barba e bigode, faces com óculos).

A opção por imagens em escala de cinza baseou-se no fato de não haver necessidade do uso de cor para o algoritmo proposto.

As imagens foram armazenadas num banco de arquivos no formato bitmap.

\subsubsection{Pré-Processamento}

O pré-processamento é constituído de procedimentos que visam preparar, satisfatoriamente, a imagem para uma determinada finalidade, no caso, a investigação de proporções faciais áureas.

As técnicas de pré-processamento podem ser úteis para minimizar efeitos de variações de luminosidade (brilho), contraste e ruído de diferentes naturezas. Para tanto, faz-se necessária a utilização de metodologias de modificação de histogramas e filtragem no domínio espacial ou freqüêncial.

Dessa forma, o pré-processamento foi implementado em três passos principais, conforme a Figura 4.2.

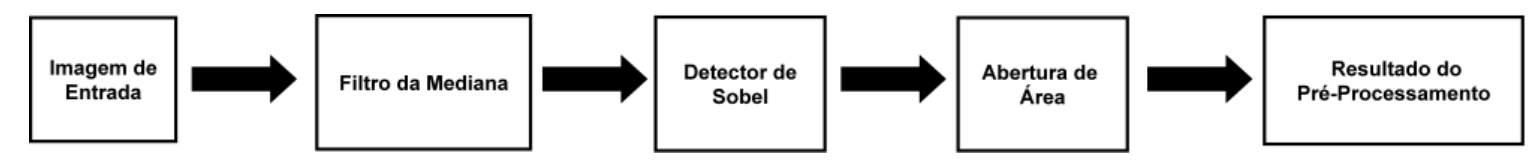

Figura 4.2: Etapas do Pré-Processamento 
Para reduzir ruídos existentes nas imagens digitais, o primeiro passo do pré-processamento foi aplicar o filtro da mediana na imagem de entrada. Este filtro foi aplicado não somente visando a redução de ruídos como também a preservação das bordas na imagem. Na Figura 4.3 tem-se a imagem de entrada e na Figura 4.4 pode-se visualizar o resultado do filtro da mediana utilizando-se a vizinhança $3 \times 3$.

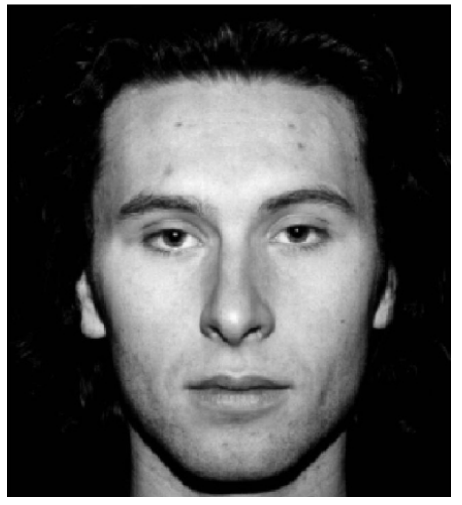

Figura 4.3: Imagem Original

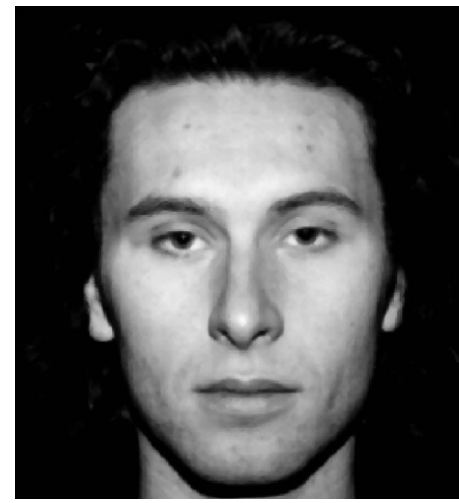

Figura 4.4: Filtro da Mediana

A seguir, foi aplicado um detector de bordas na imagem. Utiliza-se o detector de Sobel, pois este consegue um desempenho bastante satisfatório na detecção das bordas dos elementos principais da face (sobrancelha, olhos, nariz, boca), como também em todo contorno da face. A Figura 4.5 mostra o resultado obtido através do detector de Sobel.

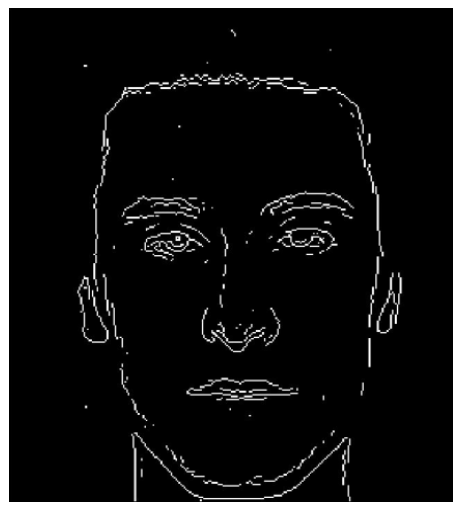

Figura 4.5: Detector de Sobel

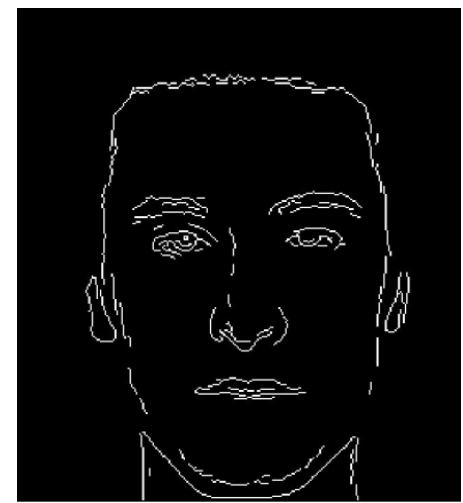

Figura 4.6: Abertura de Área

O último passo do pré-processamento é a abertura de área visando a remoção de pequenos objetos e/ou ruídos da imagem binária. Esta operação remove, a partir de uma imagem binária, todos componentes conectados que tiverem tamanho menor do que 5 pixels proporcionando uma imagem binária com menos ruídos, conforme pode-se observar na Figura 4.6. 


\subsubsection{Extração de Características}

O algoritmo é capaz de medir quatro estruturas geométricas, sendo duas unidimensionais e duas bidimensionais proporcionalmente áureas. As estruturas foram escolhidas sob o respaldo teórico adquirido e sob a perspectiva de alguns trabalhos do meio científico, principalmente na área médica (RICKETTS, 1982)(OLIVEIRA JR., 2000)(MAQUARDT, 2001).

A extração de características possui quatro passos, conforme mostra a Figura 4.7.

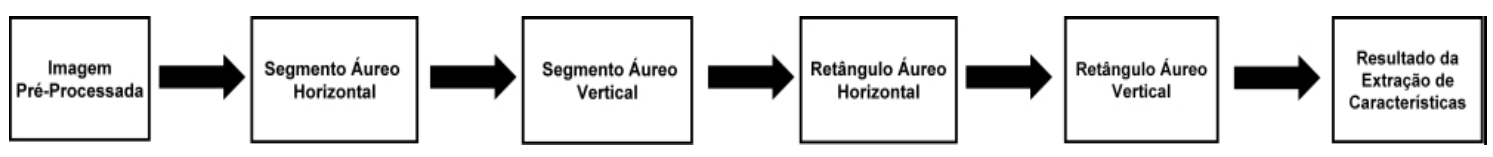

Figura 4.7: Etapas da Extração de Características

A partir da imagem pré-processada realiza-se uma busca por segmentos e retângulos áureos horizontais e verticais na imagem. No processo de extração de características a imagem foi separada em quatro regiões conforme mostra a Figura 4.8.

A divisão em regiões foi realizada visando-se a implementação do classificador "fuzzy" que traçará as regras considerando tais regiões.

A região 1 na imagem é determinada pela região de testa e cabelo da face. Na região 2 , tem-se a região de sobrancelhas e olhos e na região 3, a região do nariz. Finalmente, a região 4 é determinada pela região de boca e queixo da face.

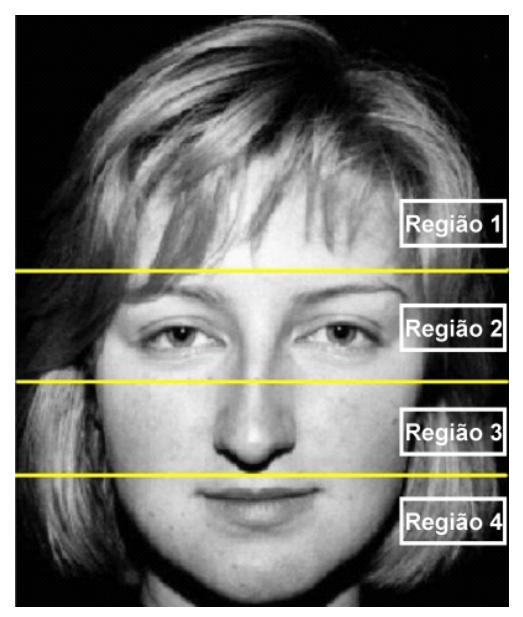

Figura 4.8: Regiões da Face 
Na Figura 4.8, as linhas representam a fronteira entre cada uma das quatro regiões. Delimita-se cada uma das fronteiras das regiões utilizando-se como referência a linha (coordenada $x$ da imagem) do ponto médio. A primeira, segunda e terceira fronteira estão localizadas aproximadamente $25 \%$ acima, $30 \%$ abaixo e $70 \%$ abaixo da linha ponto médio da face, respectivamente. A Figura 4.9 mostra o ponto médio da face.

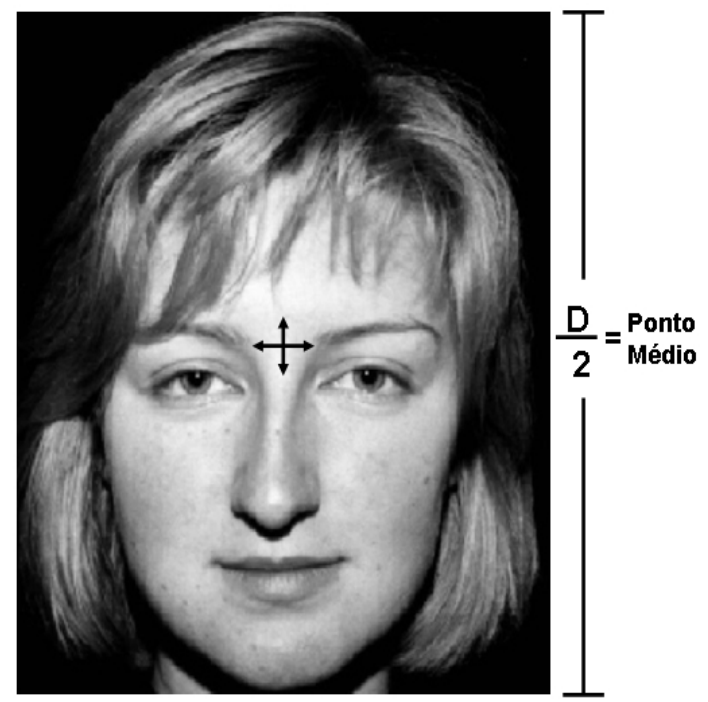

Figura 4.9: Ponto Médio da Face

Para determinar o ponto médio calcula-se a distância máxima vertical da face (D) na imagem binarizada e, a seguir, dividi-se essa distância por dois, conforme mostra a Figura 4.9 .

Utiliza-se a distância Euclidiana para determinar as medidas do segmento e retângulo áureo e a distância máxima vertical e horizontal da face na imagem.

Dados os pixels $p$ e $q$, de coordenadas $(x, y)$ e $\left(x_{1}, y_{1}\right)$, respectivamente, a distância Euclidiana é dada pela equação 1 .

$$
D(p, q)=\sqrt{\left(x_{1}-x\right)^{2}+\left(y_{1}-y\right)^{2}}
$$




\subsubsection{Segmento Áureo Horizontal e Vertical}

A estrutura unidimensional corresponde ao segmento de reta com extremidade $A$ e $B$, interceptado por um ponto $S$ que o divide em dois segmentos $\overline{A S}$ e $\overline{S B}$. Os segmentos originados relacionam-se segundo a razão áurea, conforme a Figura 4.10.

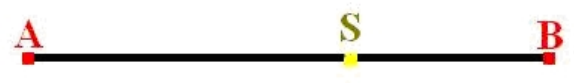

Figura 4.10: Segmento Áureo

Em outras palavras, isto significa que é possível obter um ponto $S$ que permite encontrar um segmento áureo neste segmento $\overline{A B}$, utilizando-se da seguinte razão:

$$
\frac{A B}{A S}=\frac{A S}{S B}=\Phi
$$

Dessa maneira, determina-se a distância entre dois pontos, por exemplo, a distância do ponto $A$ ao ponto $S$ e, a partir deste último, realiza-se a varredura nas distâncias com os pontos sucessores em busca do segmento que ratifique a relação. Portanto, o segundo ponto envolvido na primeira medida corresponde, sempre, ao ponto $S$ que é o divisor de $\overline{A B}$ em média e extrema razão - "ponto áureo".

A busca do segmento áureo horizontal inicia-se primeiramente determinando o segmento áureo da distância máxima horizontal da face. Encontrado este primeiro segmento realiza-se uma busca em cada uma das quatro regiões por pontos que ratifiquem esta medida. Logo, o número de ocorrências do segmento encontrado na face é armazenado em uma variável que posteriormente será a característica de entrada do classificador.

Terminada a busca com essa primeira medida procede-se uma redução de $10 \%$ do tamanho total do segmento anterior, originando-se uma nova medida. Novamente, encontra-se o ponto áureo desta segunda medida e realiza-se uma outra varredura por região na imagem.

Este processo de redução, determinação do novo segmento e varredura na imagem ocorre até que segmento áureo atual seja $70 \%$ menor do que o primeiro segmento áureo encontrado a partir distância máxima horizontal da face. 
Os segmentos menores do que $30 \%$ do tamanho do primeiro segmento são desconsiderados, pois apresentam medida entre pixels muito reduzida, fato irrelevante no processo de investigação biométrica.

Para uma melhor compreensão acerca dos segmentos áureos encontrados na face, a Figura 4.11, apresenta alguns exemplos de segmentos áureos horizontais detectados em cada uma das quatro regiões.

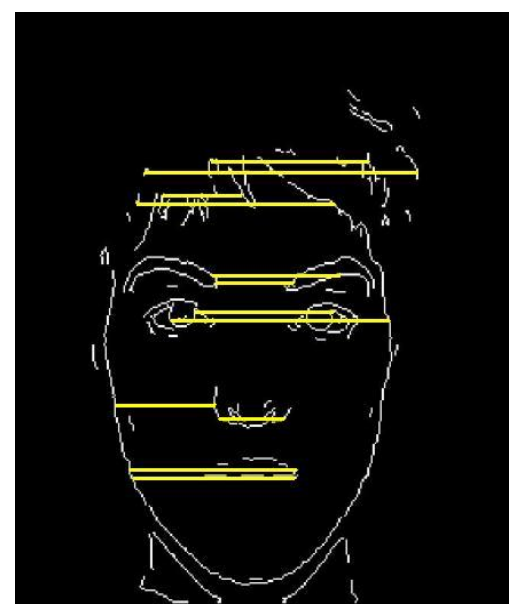

Figura 4.11: Segmentos Áureos Horizontais detectados na face

A próxima estrutura unidimensional utilizada nesta extração de características foi o segmento áureo vertical. A Figura 4.12 mostra o segmento áureo vertical, o qual possui os mesmos fundamentos teóricos do segmento áureo apresentando anteriormente na Figura 4.10 .

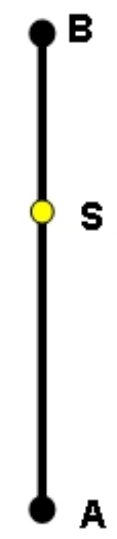

Figura 4.12: Segmento Áureo Vertical

Há pequenas diferenças quando se compara a busca do segmento áureo vertical e horizontal. Assim, determina-se a distância máxima vertical da face na imagem e, em seguida, realiza-se uma redução de $70 \%$ desta distância, obtendo o tamanho mínimo do 
segmento áureo utilizado nesta investigação. Nessa busca são desconsiderados segmentos menores do que $30 \%$ da distância máxima vertical da face, que são irrelevantes no processo de investigação biométrica como dito anteriormente. A partir do tamanho mínimo do segmento áureo encontra-se o ponto áureo do mesmo e executa-se uma busca por regiões na imagem. O número de ocorrências do segmento encontrado na face é, também, armazenado em uma variável que posteriormente será a característica de entrada do classificador. A seguir, realiza-se um aumento de $10 \%$ no tamanho do último segmento determinado originando-se uma nova medida.

Finalmente, encontra-se o ponto áureo desta segunda medida e realiza-se uma outra varredura nas região definidas anteriormente (Figura 4.8). E, este processo de aumento, determinação do novo segmento e varredura na imagem ocorre até que o segmento áureo atual não exceda o tamanho máximo determinado, na coordenada $x$, em cada região da imagem.

A Figura 4.13, mostra alguns exemplos de segmentos áureos verticais encontrados na face.

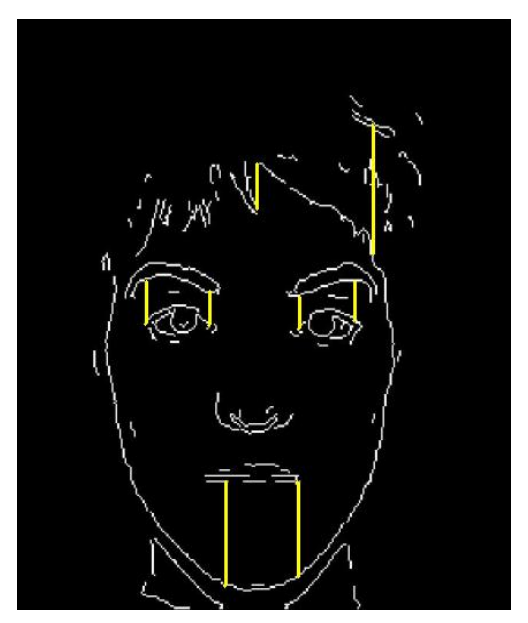

Figura 4.13: Segmentos Áureos Verticais detectados na face

Após a busca por segmentos áureos horizontais e verticais, efetua-se nova busca utilizando-se os retângulos áureos. 


\subsubsection{Retângulo Áureo Horizontal e Vertical}

As áreas que buscam a tradução matemática da estética humana destacam sobre a face humana outras formas geométricas relevantes tais como os retângulos áureos.

Adotando-se a prerrogativa da disposição e alinhamento verticais e horizontais dos elementos faciais, os retângulos áureos adaptáveis à finalidade almejada são compostos por lados/segmentos paralelos aos eixos cartesianos da imagem.

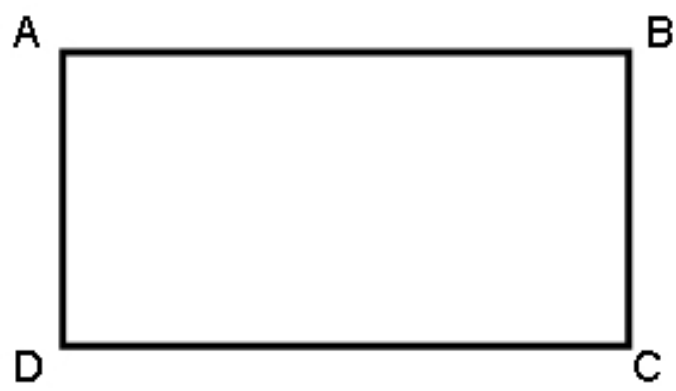

Figura 4.14: Retângulo Áureo

A configuração do retângulo áureo, demonstrado na Figura 4.14, delineia-se através de seus lados, ou seja, $a=\overline{A B}=$ lado maior e $b=\overline{B C}=$ lado menor. O retângulo áureo é o retângulo que tem seus lados $a$ e $b$ em razão áurea:

$$
\frac{a}{b}=\Phi=\frac{1+\sqrt{5}}{2}
$$

Para determinar a medida dos lados do retângulo áureo utilizou-se a sequiência de Fibonacci ${ }^{1}$ :

$$
1,1,2,3,5,8,13,21,34, \ldots
$$

Como primeira medida dos lados do retângulo áureo utilizou-se o quarto termo dessa seqüência como medida do lado menor e o quinto termo como medida do lado maior. Logo, definida esta medida realiza-se uma busca em cada uma das quatro regiões da imagem pelos retângulos áureos horizontais .

O número de retângulos áureos encontrados na face são armazenados em uma variável que posteriormente será o valor de entrada do classificador. Terminada essa busca

\footnotetext{
${ }^{1}$ Para uma melhor explanação sobre a seqüência de Fibonacci, veja o Apêndice B.
} 
utiliza-se os próximos valores da sequiência de Fibonacci como novas medidas dos lados do retângulo, ou seja, o quinto termo da seqüência é atribuído como medida do lado menor e o sexto termo é atribuído como medida do lado maior.

Esse processo é repetido até que o tamanho dos lados não ultrapassem a largura da imagem e nem a fronteira de cada uma das regiões. A Figura 4.15, mostra alguns exemplos de retângulos áureos encontrados na face.

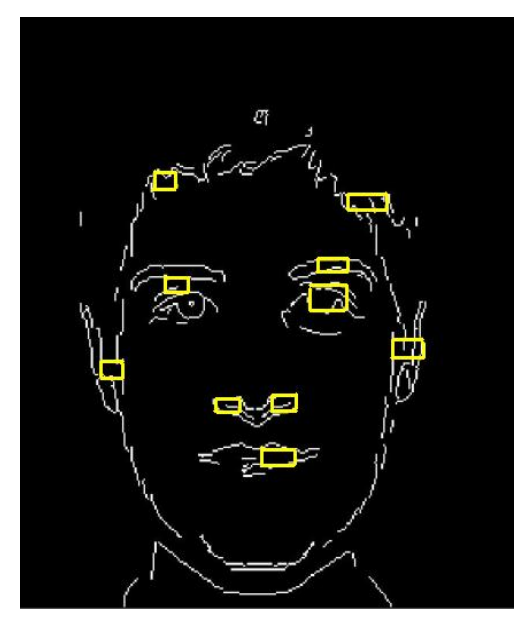

Figura 4.15: Retângulos Áureos Horizontais detectados na face

Os princípios teóricos que norteiam a busca pelos retângulos áureos horizontais na imagem são os mesmo para os retângulos áureos verticais. A Figura 4.16 ilustra o retângulo áureo vertical.

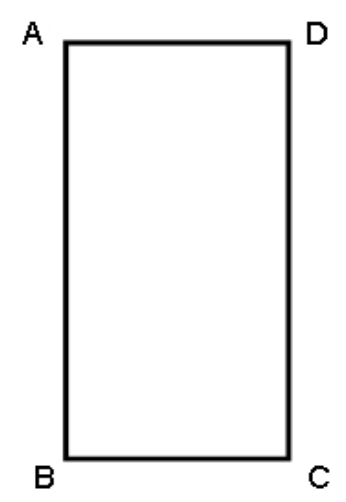

Figura 4.16: Retângulo Áureo Vertical

A última extração de características dá-se através do retângulo áureo vertical com as medidas dos lados baseados na sequiência de Fibonacci. A Figura 4.17, mostra alguns exemplos dos retângulos áureos verticais encontrados na face. 


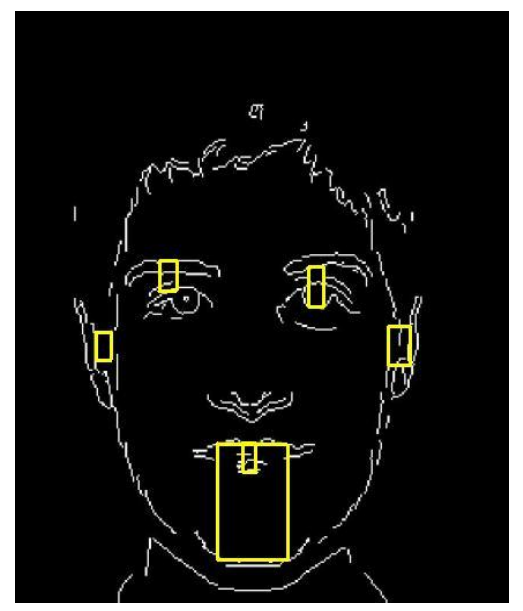

Figura 4.17: Retângulo Áureo Vertical detectado na face

\subsubsection{Classificador}

Para classificar a imagem em face ou não-face foi utilizado um classificador baseado na Lógica "Fuzzy". Essa abordagem foi proposta devido ao carácter dos dados, ou seja, os segmentos e retângulos áureos localizados dependem de conhecimento humano (regras de inferência) para que definam uma face. Essa etapa de classificação possui quatro passos principais que são mostrados através do diagrama de blocos da Figura 4.18.

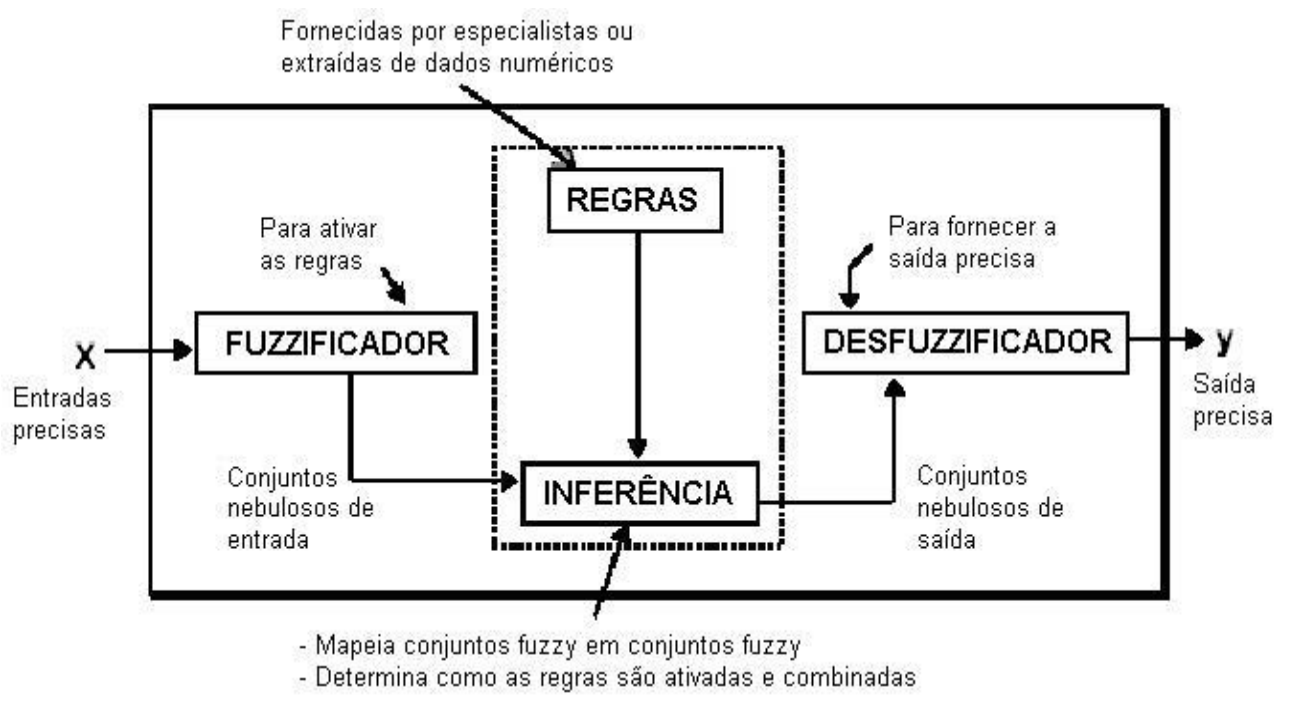

Figura 4.18: Sistema Fuzzy 
O primeiro bloco do sistema "fuzzy" é responsável pela fuzzificação das entradas precisas em conjuntos "fuzzy" e geração das funções de pertinência.

As regras são implicações lógicas, que são formulações encadeadas no formato if-then-else. Esta formulação das regras exige conhecimento especialista ou conhecimento extraído de dados numéricos.

O bloco de inferência é o responsável por obter os conjuntos "fuzzy" de saída, dado os conjuntos "fuzzy" de entrada. Para realização disso obedece-se a implicação de cada regra operando com composições de máximo (OR) ou mínimo (AND).

O desfuzzificador é o responsável por gerar uma saída precisa ao invés de um conjunto de saída. Isto dá-se através de diferentes métodos como a média dos máximos, altura máxima e centróide.

A partir do modelo do sistema "fuzzy" apresentado na Figura 4.18, foi desenvolvido classificador da imagem em face ou não-face, o qual é formado por uma rede "fuzzy", conforme ilustrado na Figura 4.19.

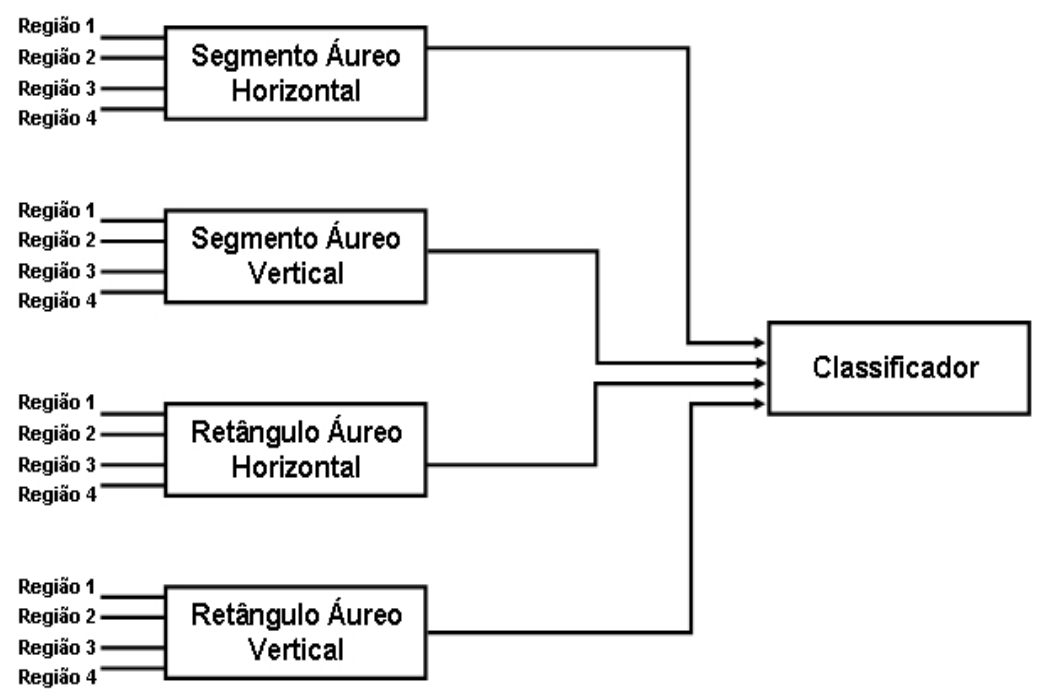

Figura 4.19: Rede Fuzzy

A rede "fuzzy" é composta por quatro sistemas "fuzzy" que são: segmento áureo horizontal, segmento áureo vertical, retângulo áureo horizontal e retângulo áureo vertical, que operam individualmente. O resultado desses sistemas é a entrada do classificador resultará em "face ou "não-face".

Seguindo a mesma configuração do sistema "fuzzy", apresentado na Figura 4.18, gerou-se as funções de pertinência de investigação biométrica observando-se a frequiên- 
cia com que os resultados dos números de segmentos e retângulos áureos detectados no banco de imagens de treinamento aparecem nos gráficos ${ }^{2}$.

Somente foram utilizados os dados advindos do segmento áureo horizontal para explicar como se realiza a implementação do sistema "fuzzy" na plataforma MATLAB. Salienta-se que a implementação dos sistemas "fuzzy" do segmento áureo vertical e do retângulo áureo horizontal e vertical dá-se da mesma forma.

Para se implementar o sistema de inferência "fuzzy" do segmento áureo horizontal utiliza-se a interface gráfica disponível no "Toolbox" de Lógica "Fuzzy" do MATLAB. Este possui uma ferramenta chamada "FIS Editor", que facilita o desenvolvimento do sistema de inferência "fuzzy", conforme pode-se observar na Figura 4.20.

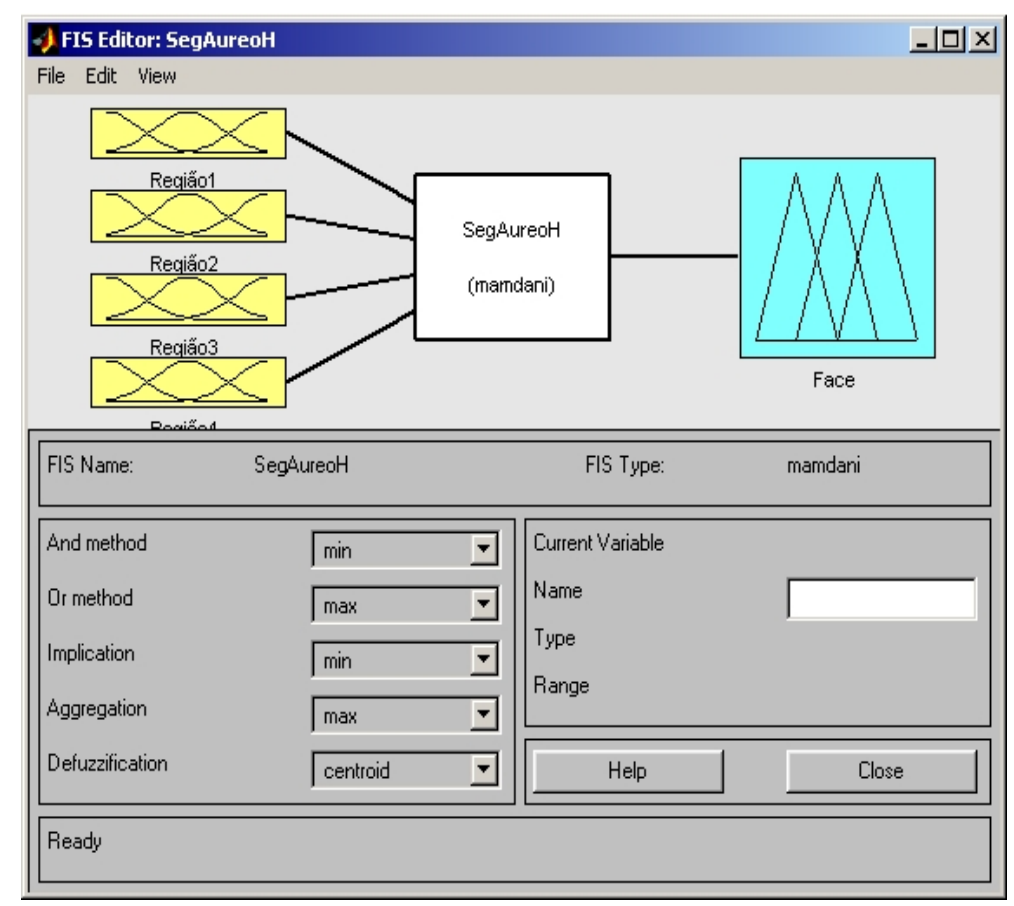

Figura 4.20: Sistema Fuzzy do Segmento Áureo Horizontal

Esta parte do modelo é composto de 4 entradas, referentes às 4 regiões, e 1 saída. Cada uma das 4 entradas recebe o seu respectivo número de segmentos áureos encontrados na região, ressaltando-se que os métodos de implicação, agregação e desfuzzificação utilizados neste sistema são os respectivamente: mínimo, máximo e centróide.

Após, definido o número de entradas e a saída determina-se as funções de pertinência conferindo-se a cada uma delas sua respectiva variável lingüística. As variáveis lingüísticas definidas foram: Muito, Médio e Pouco.

\footnotetext{
${ }^{2}$ Os gráficos que demonstram os resultados da etapa de extração de características estão no Apêndice C.
} 
Para estabelecer o intervalo de atuação de cada uma das variáveis lingüísticas observou-se o intervalo onde a freqüência do número de segmentos detectados na imagem era mais significativa e menos significativa, ou seja, os extremos dos gráficos ${ }^{3}$ da extração de características. Na Figura 4.21, pode-se visualizar as funções de pertinências do sistema "fuzzy" do segmento áureo horizontal.

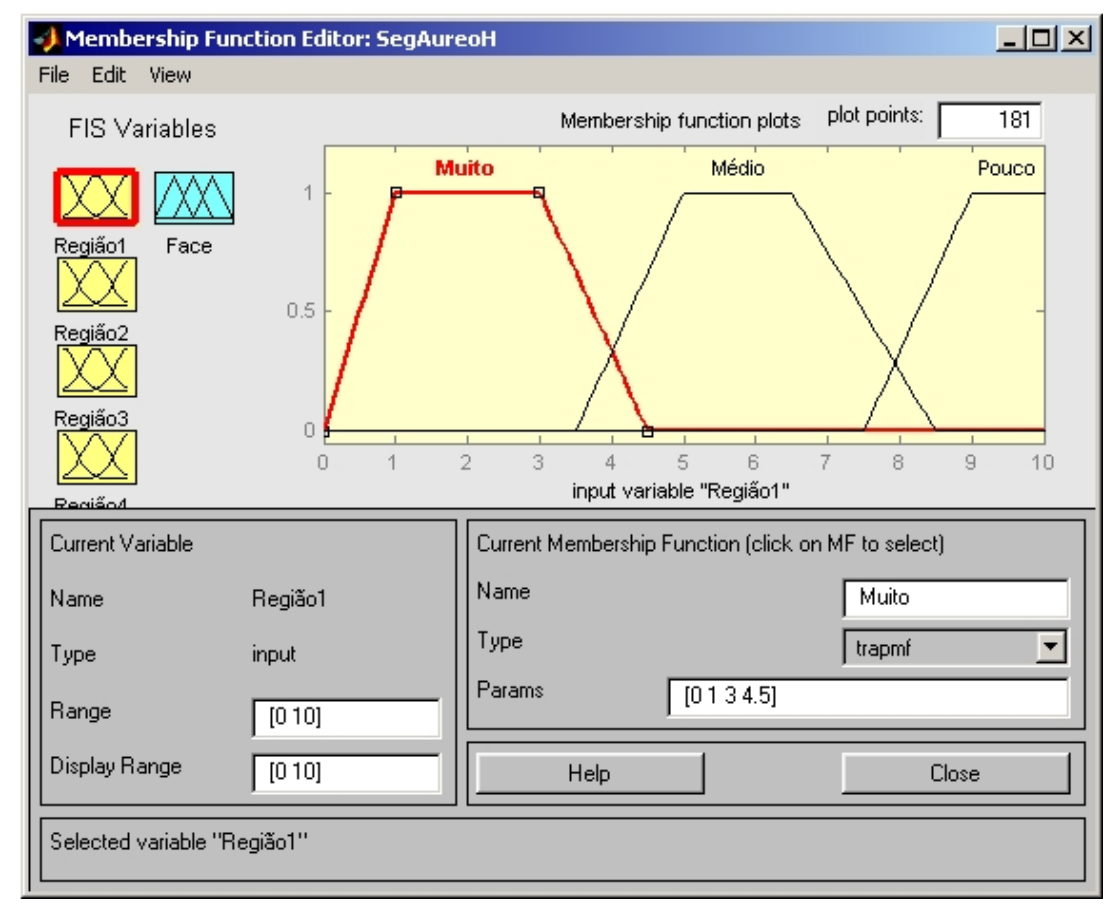

Figura 4.21: Funções de Pertinências do Sistema Fuzzy do Segmento Áureo Horizontal

As funções de pertinências podem conter diversos formatos, sendo que o formato que melhor modelou os dados de entrada foi o da função trapezoidal. Os valores de maior incidência dentro dessa função são os valores da base do trapézio e os extremos são valores estipulados de menor incidência na função.

A partir do estabelecimento das funções de pertinência foram definidas as regras de inferências "fuzzy".

Primeiramente, implementou-se o sistema com 79 regras de inferências sendo que, a partir desse número realizou-se um refinamento excluindo-se aquelas que possuíam pouca ou nenhuma ativação. Dessa forma, chegou-se ao número total de 34 regras de inferências, sem que o mesmo não sofresse depreciação nos resultados. A Figura 4.22 mostra algumas dessas regras de inferências utilizadas para o segmento áureo horizontal.

\footnotetext{
${ }^{3}$ Os gráficos que demonstram os resultados da etapa de extração de características estão no Apêndice C.
} 


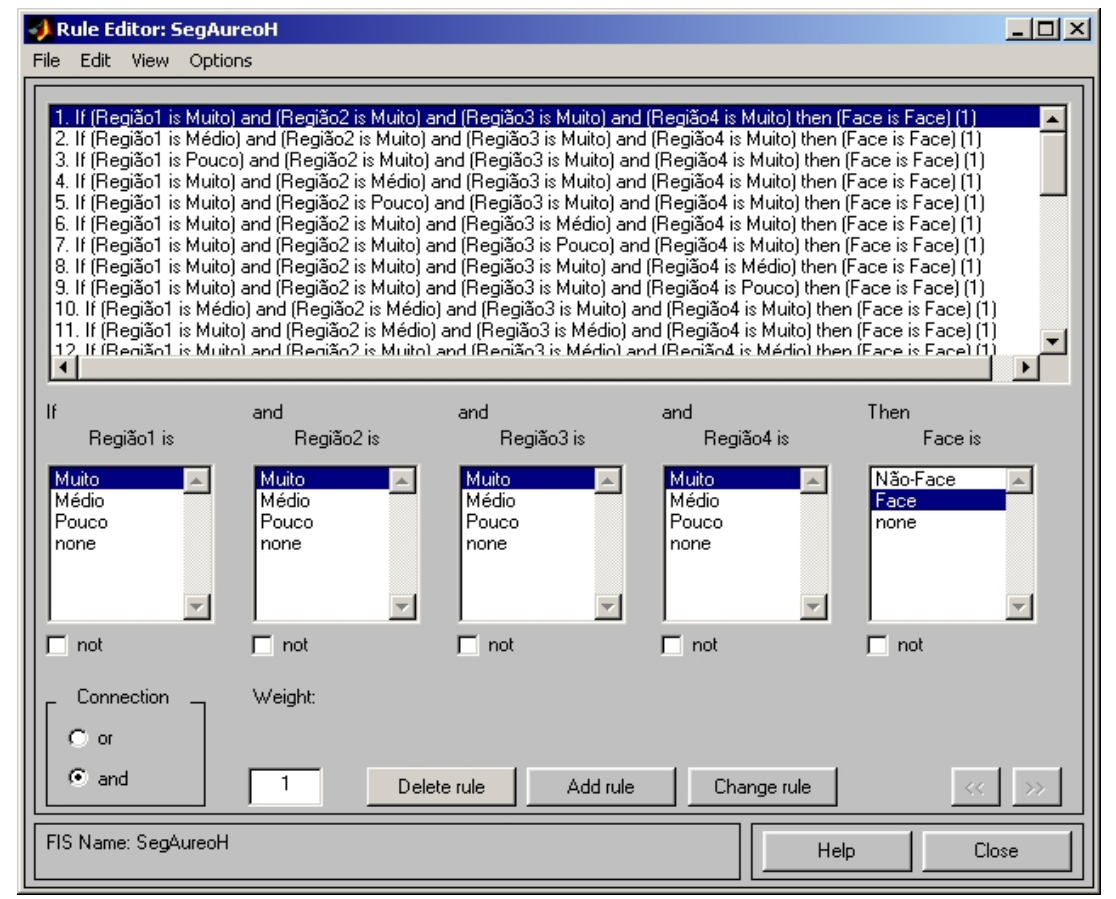

Figura 4.22: Regras de Inferências para o Segmento Áureo Horizontal

Como dito anteriormente, a implementação do sistema "fuzzy" do segmento áureo vertical e do retângulo áureo horizontal e vertical segue os mesmos passos e idéias estabelecidas no sistema "fuzzy" do segmento áureo horizontal.

A próxima etapa da rede "fuzzy" é a classificação.

O classificador foi implementado com 4 entradas e 1 saída, onde cada uma dessas entradas corresponde ao resultado obtido dos sistemas "fuzzy" do segmento e retângulo áureo horizontal e vertical. Na Figura 4.23, pode-se visualizar o sistema "fuzzy" do classificador. 


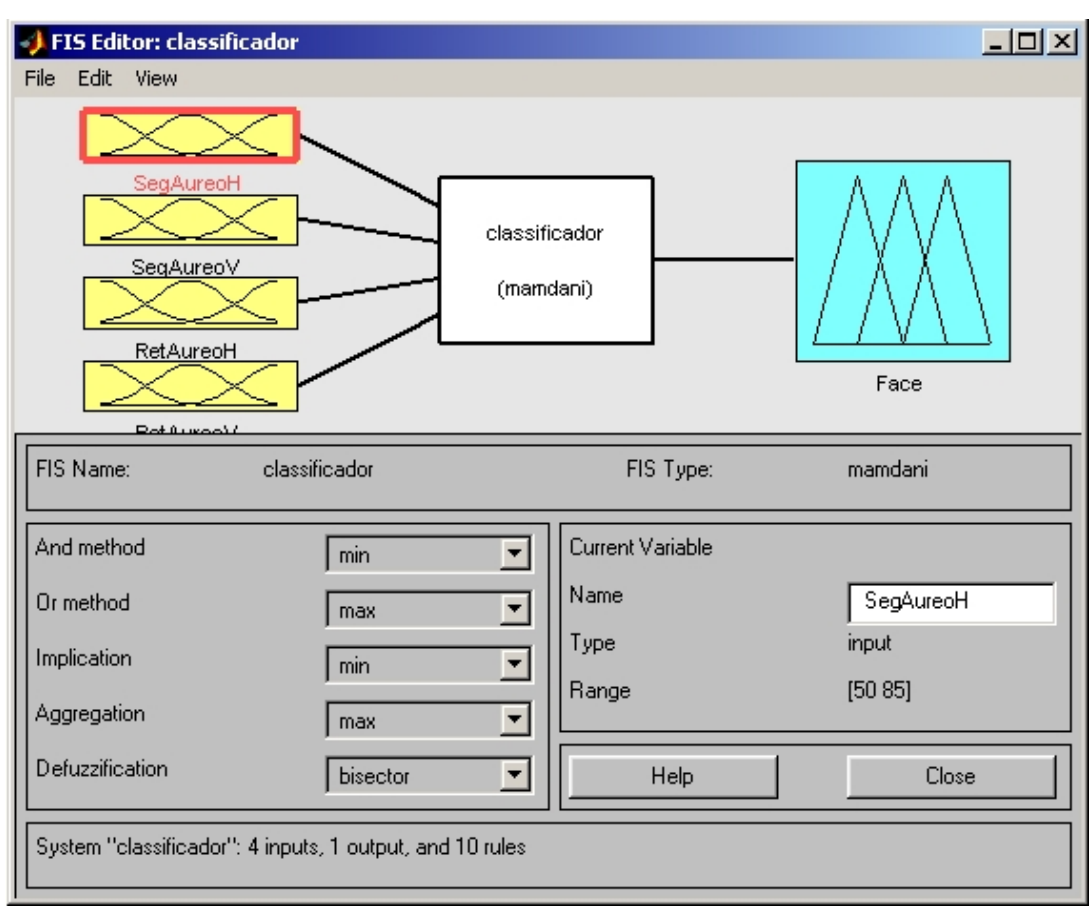

Figura 4.23: Sistema Fuzzy do Classificador

Foram então definidas as funções de pertinência do sistema "fuzzy" do classificador. Foi utilizada a função de pertinência na forma trapezoidal conferindo à função duas variáveis lingüísticas: Face e Não-Face. Essas funções de pertinências são mostradas na Figura 4.24.

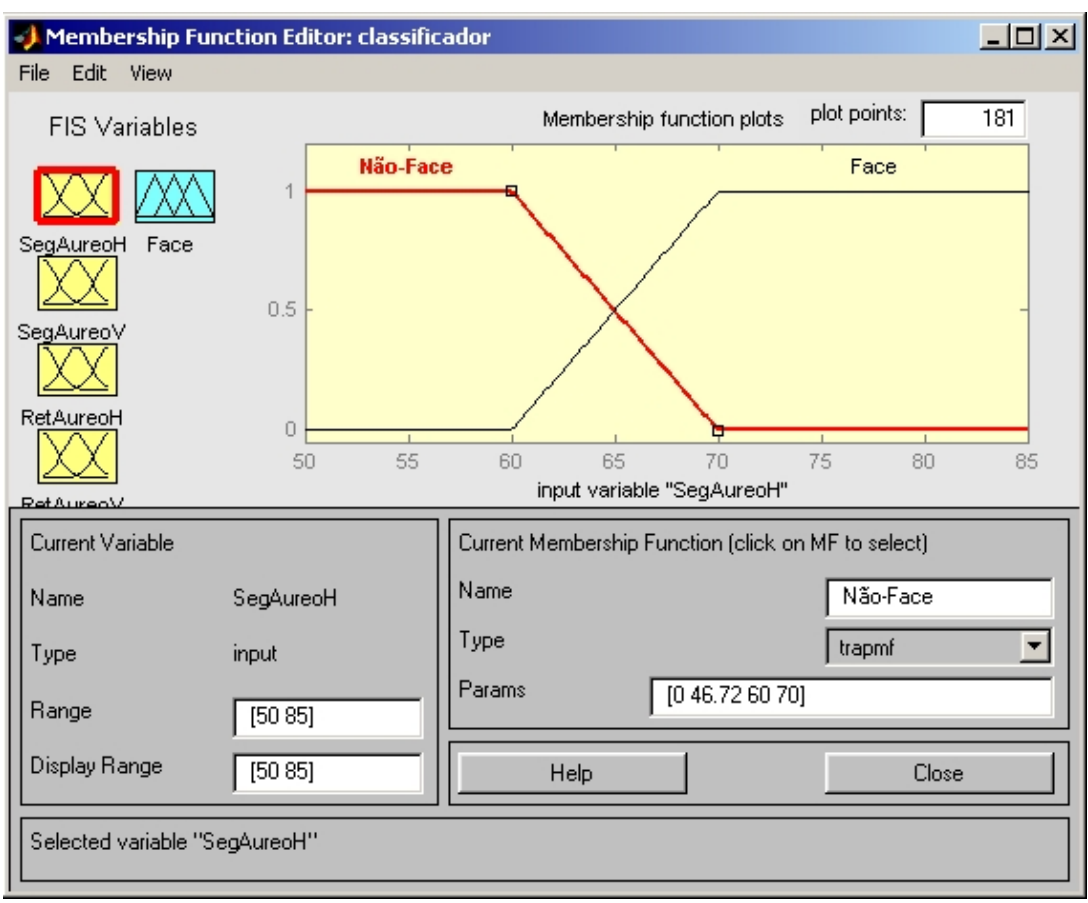

Figura 4.24: Funções de Pertinências do Sistema Fuzzy do Classificador 
A partir das funções pertinências define-se as regras de inferência "fuzzy". Para o classificador foram criadas 10 regras de inferências. A Figura 4.25 mostra algumas dessas regras.

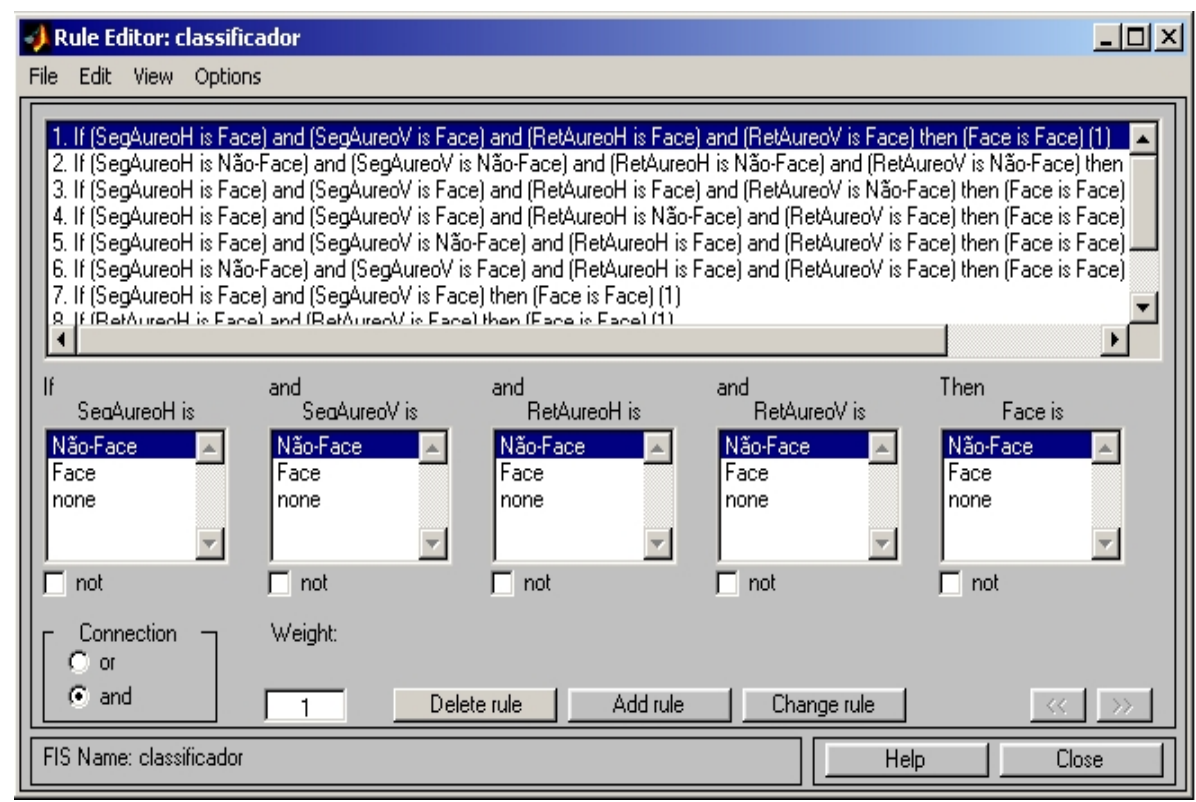

Figura 4.25: Regras de Inferências do Sistema Fuzzy do Classificador

Desta maneira, finaliza-se a implementação do classificador e consequentemente a implementação da rede "fuzzy". Logo, o algoritmo de investigação biométrica baseado na Proporção Divina recebe o resultado de saída da rede "fuzzy" e informa se a detecção realizada na imagem de entrada é uma face ou não. 


$\frac{\bar{s}}{4}$

\section{Resultados e Conclusões}

\subsection{Introdução}

Este capítulo traz os resultados e conclusões obtidas pelo algoritmo de investigação biométrica para detecção de faces humanas através da Proporção Divina aplicado no banco de imagens de treinamento e no banco de imagens de teste. Apresenta-se também as propostas para futuros trabalhos nesta área de pesquisa.

Os resultados obtidos com a extração de características no banco de imagens de treinamento são analisados devido a relevância destes para a implementação dos sistemas "fuzzy" do algoritmo de investigação biométrica. Todos estes resultados são mostrados no Apêndice $\mathrm{C}$ e divididos nas seguintes seções: segmento áureo horizontal, segmento áureo vertical, retângulo áureo horizontal e retângulo áureo vertical. 


\subsection{Extração das Proporções Áureas}

Os gráficos a seguir mostram o número de segmentos áureos horizontais detectados nas regiões 2 e 3 da imagem na etapa de extração de características (Figuras C.2 e C.3).

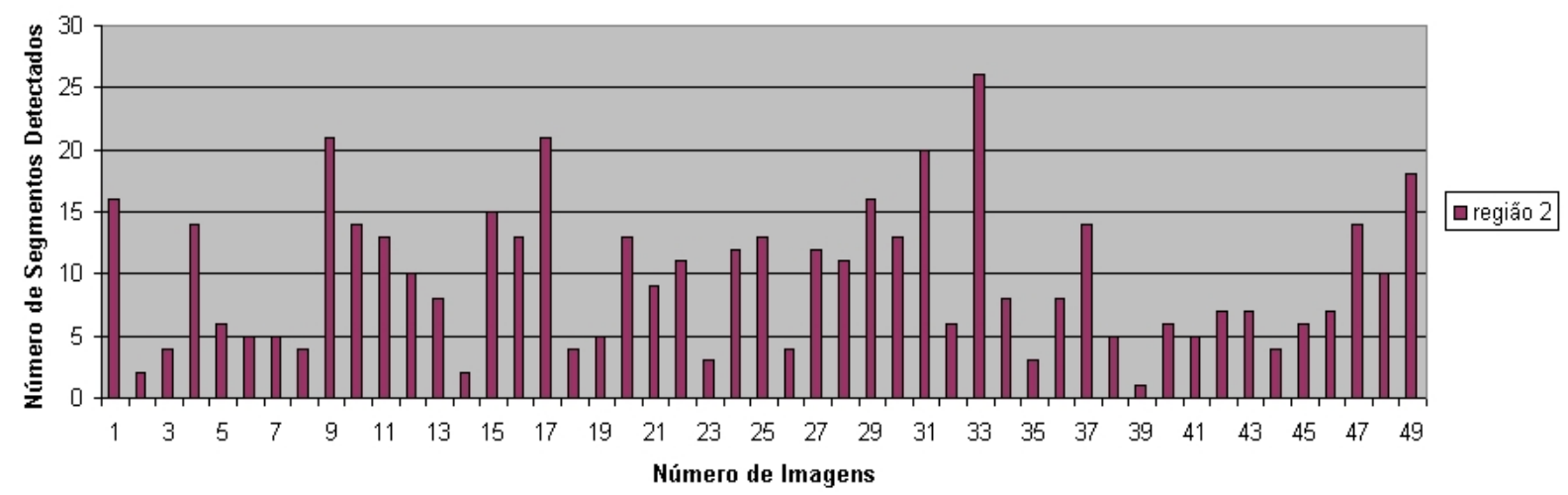

Figura 5.1: Número de Segmentos Áureos Horizontais detectados na face

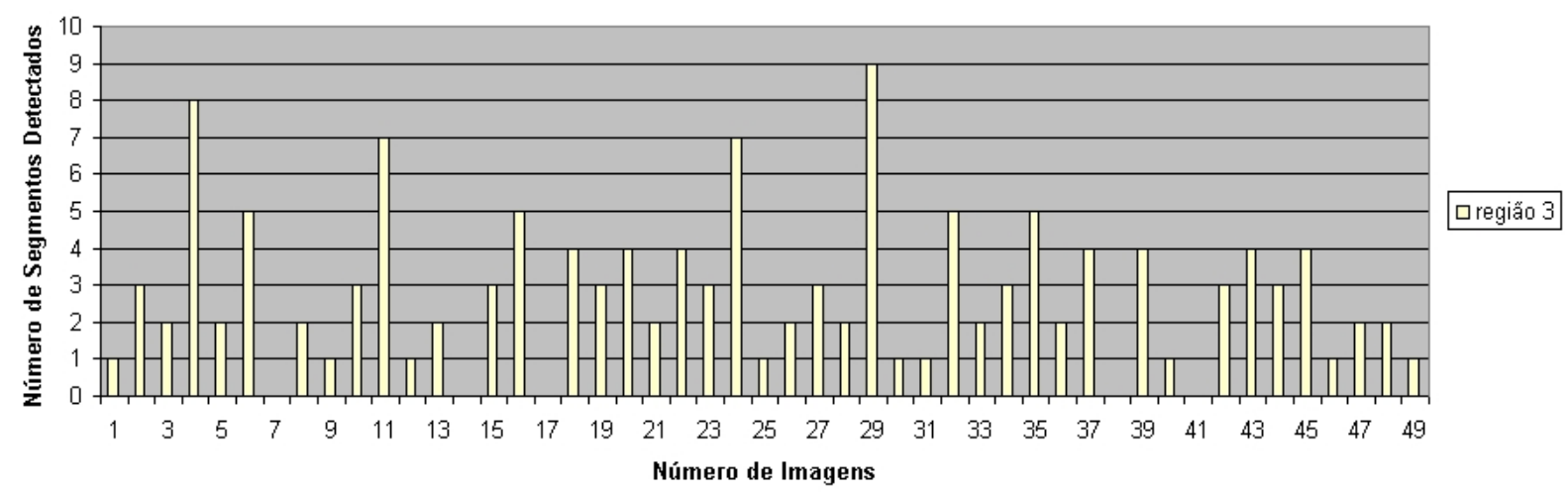

Figura 5.2: Número de Segmentos Áureos Horizontais detectados na face

$\mathrm{Na}$ imagem número 2 dos gráficos supracitados detectou-se 2 e 3 segmentos áureos horizontais nas regiões 2 e 3 da imagem, respectivamente. A Figura 5.4 mostra estes segmentos encontrados na imagem. 


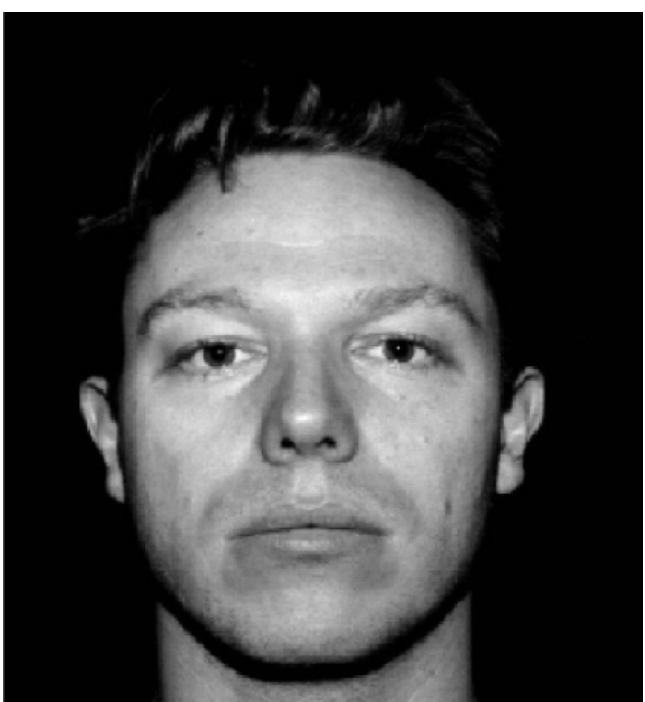

Figura 5.3: Imagem Original

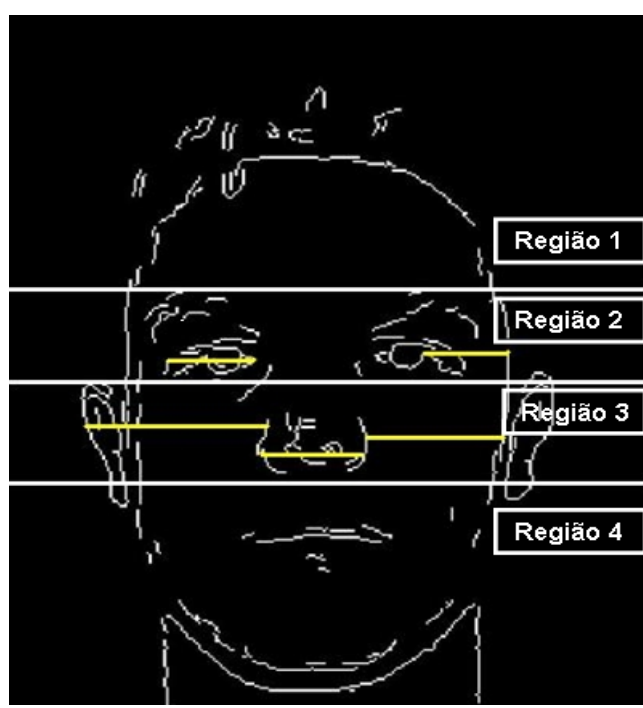

Figura 5.4: Pré-Processamento

\subsection{Resultados da Detecção}

O banco de imagens de treinamento consistiu de 100 imagens, sendo 51 faces de mulheres e 49 faces de homens. Dentre estas 100 imagens o algoritmo detectou corretamente 96 faces, ou seja, uma taxa de $96 \%$ de acerto. As 4 faces que não foram detectadas apresentam uma disparidade no número de segmentos e retângulos áureos horizontais e verticais encontrados na imagem. Na Tabela 5.1, pode-se visualizar estes resultados.

\begin{tabular}{|c|c|c|c|c|}
\hline \multirow{2}{*}{ Número de Imagens } & \multirow{2}{*}{ Acertos } & \multicolumn{2}{|c|}{ Erros } & \multirow{2}{*}{ Banco } \\
\cline { 3 - 4 } & & Falsos Negativo & Falsos Positivo & \\
\hline 100 & 96 & 4 & 0 & Treinamento \\
\hline 100 & 96 & 3 & 1 & Teste \\
\hline
\end{tabular}

Tabela 5.1: Tabela Geral dos Resultados

A Figura 5.5 é uma das 4 imagens do banco de imagens de treinamento que é classificada como "não-face".

A Figura 5.6 mostra o resultado da etapa de pré-processamento na imagem da Figura 5.5. Pode-se observar uma grande quantidade de ruídos na região 1,2 e 4 da imagem, o que provoca um aumento excessivo no número de segmentos e retângulos áureos detectados na imagem, induzindo o classificador a um falso negativo. 


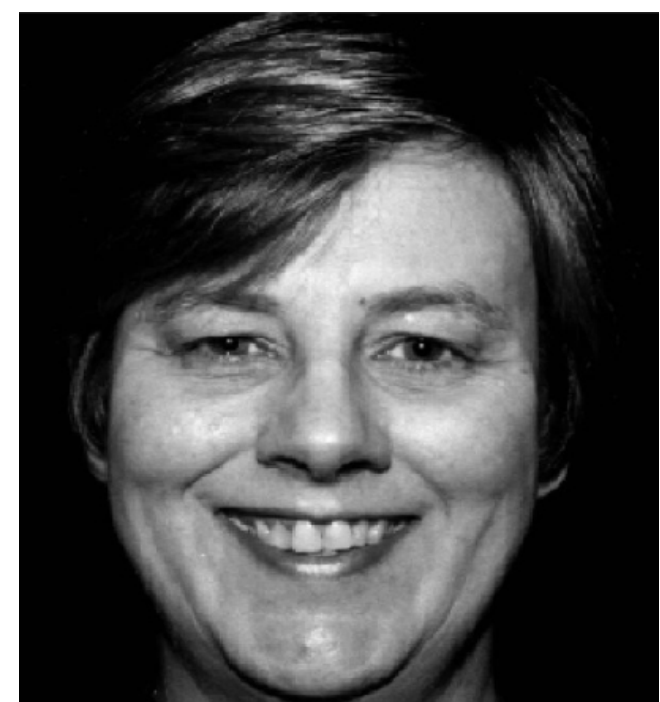

Figura 5.5: Imagem Original

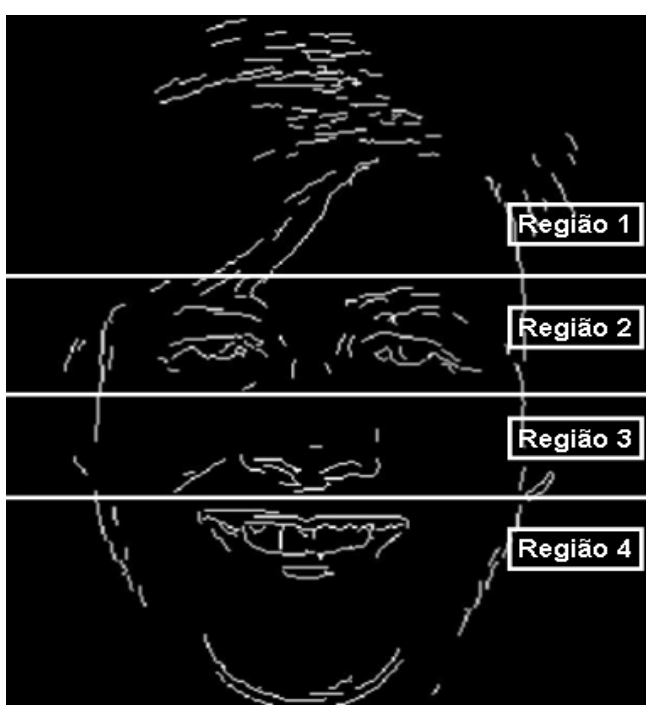

Figura 5.6: Pré-Processamento

Os demais erros cometidos pelo algoritmo no banco de imagens de treinamento devemse a este mesmo tipo de problema na etapa de pré-processamento.

Para verificar a validade do algoritmo foram selecionadas outras 100 imagens retiradas da Internet observando-se a dimensão, a condição de iluminação e a resolução da imagem. Dessa maneira, formou-se o banco de imagens de teste com 90 imagens de faces e 10 imagens de não-faces. O desempenho do algoritmo de investigação biométrica neste banco de imagens foi também de $96 \%$ de acerto nas detecções, sendo 3 falsos negativos e 1 falso positivo. Pode-se visualizar estes resultados na Tabela 5.1.

A Figura 5.7 é uma das que apresentaram erros (falso negativo) no banco de imagens de teste.

A Figura 5.8 mostra o resultado obtido na etapa de pré-processamento, onde pode-se observar uma imagem com perda de algumas características principais da face como sobrancelhas, nariz e boca. As perdas são devida a sombra e a luminosidade na imagem. 


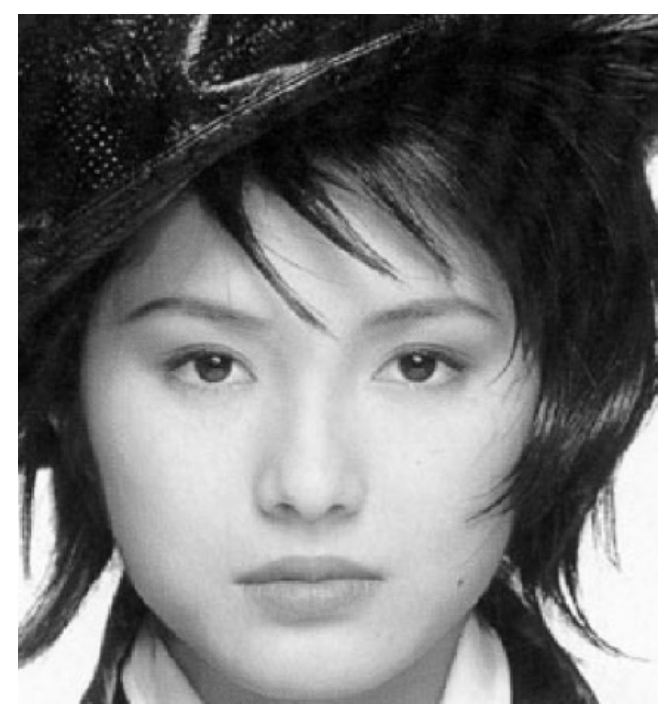

Figura 5.7: Imagem Original

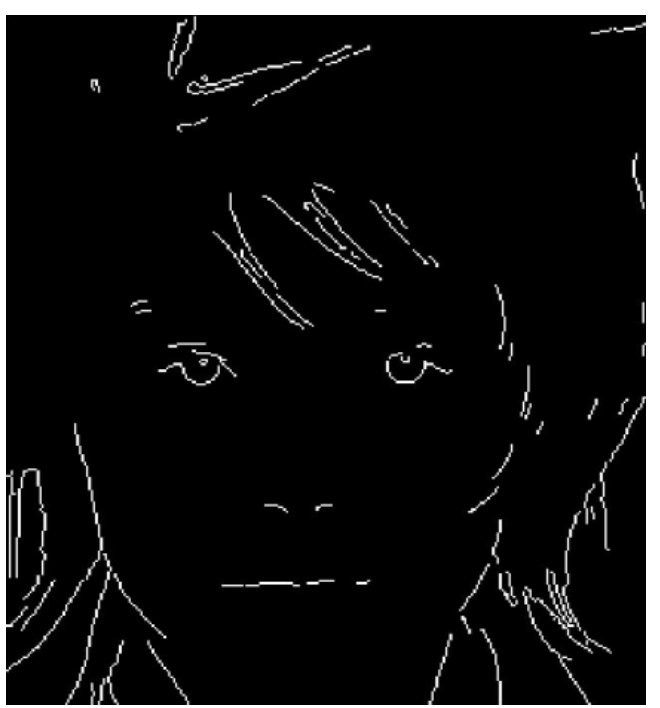

Figura 5.8: Pré-Processamento

Um outro exemplo de falso negativo apresentado é a Figura 5.9. Pode-se observar novamente que a imagem pré-processada (Figura 5.10) teve uma grande perda de contornos da face nas regiões 3 e 4 . Por esta razão, nessas regiões nenhuma das extrações de características utilizadas foram capazes de detectar segmentos e retângulos áureos, ou seja, o número de segmentos e retângulos áureos é nulo nas regiões 3 e 4 da imagem. Assim, a imagem foi classificada como não-face.

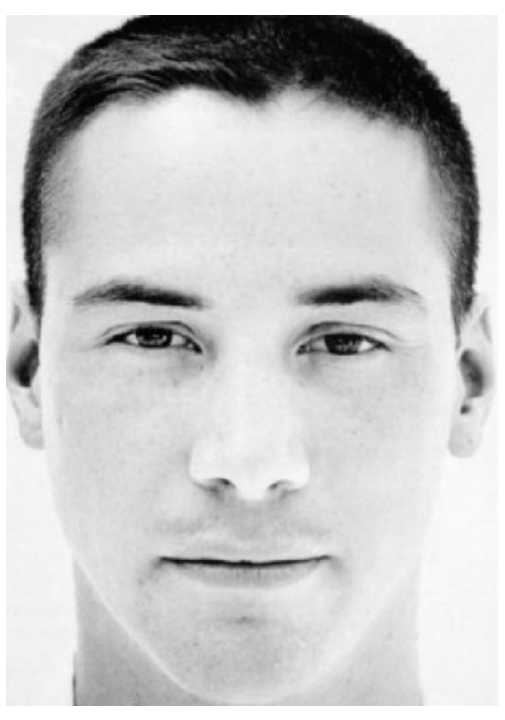

Figura 5.9: Imagem Original

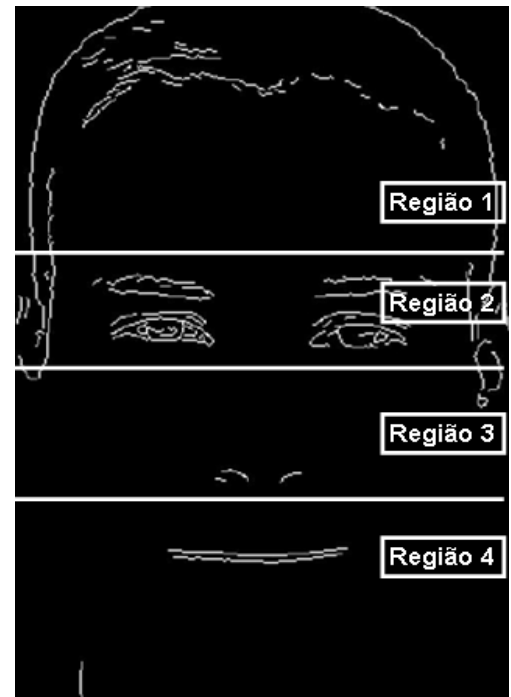

Figura 5.10: Pré-Processamento 
Como a etapa de pré-processamento é fundamental para a extração de características, a obliteração das características faciais, sombras e ruídos na imagem podem causar falhas na classificação final da imagem.

A Figura 5.11 é um exemplo de falso positivo obtido.

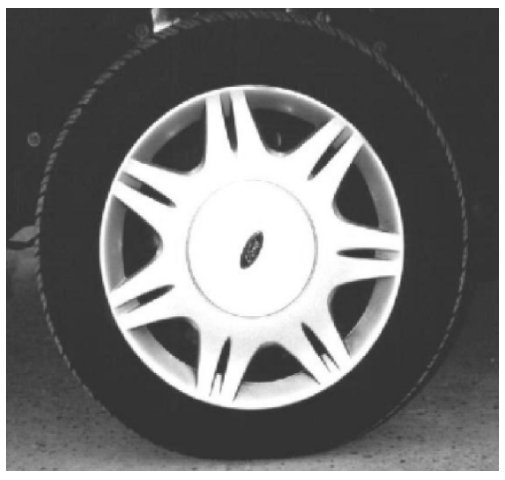

Figura 5.11: Imagem Original

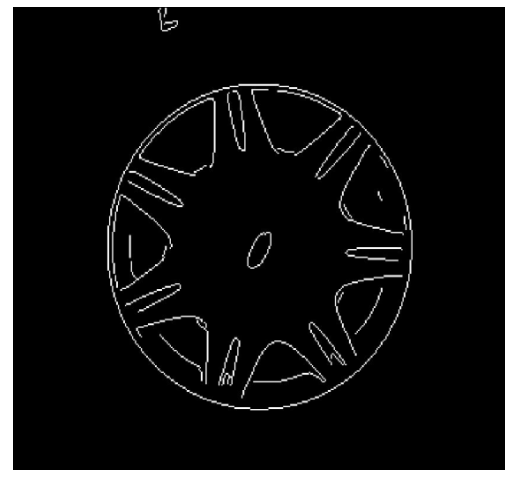

Figura 5.12: Pré-Processamento

Na Figura 5.12 pode-se observar a imagem pré-processada da roda de um veículo, a qual possui muitos detalhes internos onde foram detectados um número de segmentos e retângulos áureos próximo ao número utilizado pelo algoritmo para classificação da imagem como sendo uma face. Por isso, a imagem foi classificada como face.

As demais imagens de não-face contidas no banco de imagens de teste foram classificadas corretamente. A Figura 5.13 ilustra uma imagem onde o algoritmo realizou uma correta classificação. Esta imagem é uma escultura de face feita por índios africanos e foi classificada como não-face pelo algoritmo. Como as proporções da escultura não seguem a Proporção Divina, corretamente o algoritmo não a reconhece como uma face humana real. A Figura 5.14 mostra a correspondente imagem pré-processada. 


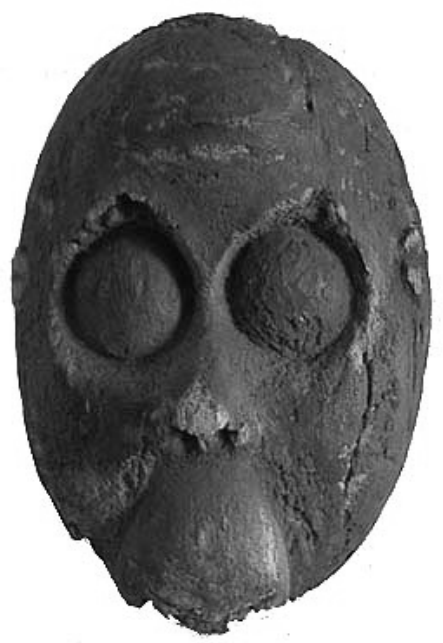

Figura 5.13: Imagem Original

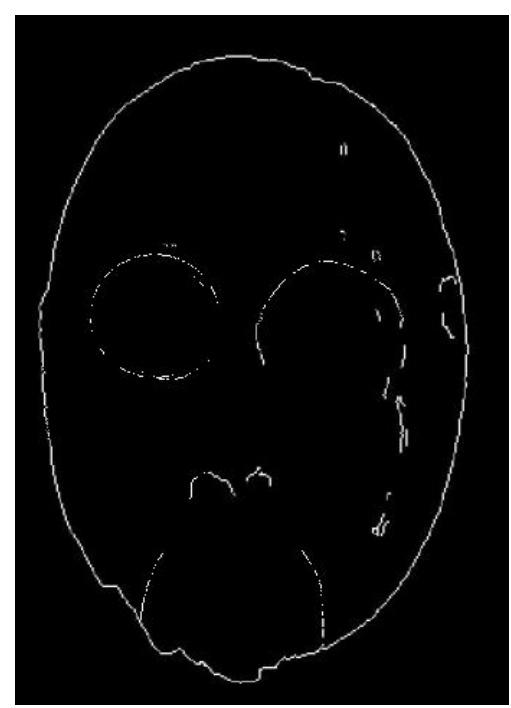

Figura 5.14: Pré-Processamento

Outro exemplo de imagem corretamente classificada pelo algoritmo é a Figura 5.15 que é uma modelagem de face desenvolvida no "software" 3D Studio MAX. Pode-se observar que nesta imagem temos uma face com todas as características faciais, entretanto, estas não possuem proporções áureas. Logo, o algoritmo de investigação biométrica classifica esta imagem como não-face. O resultado do pré-processamento é mostrado na Figura 5.16.

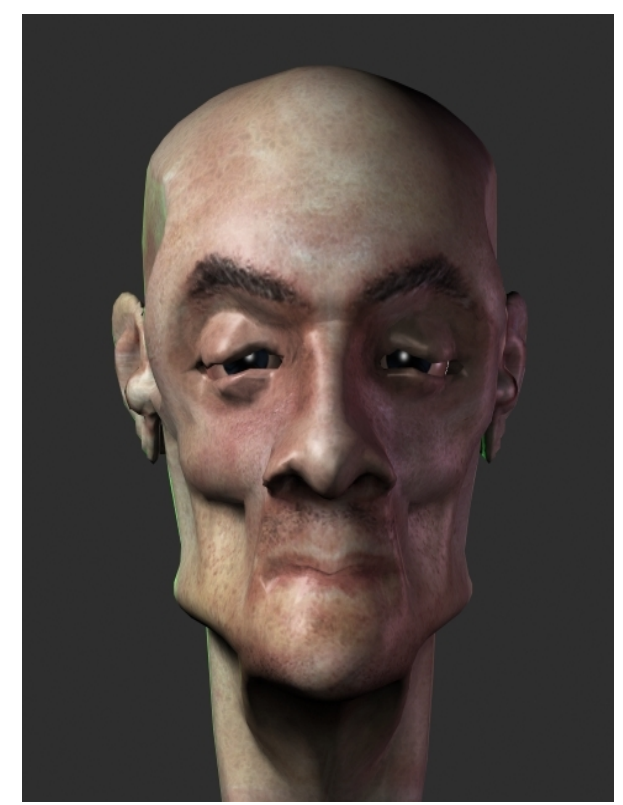

Figura 5.15: Imagem Original

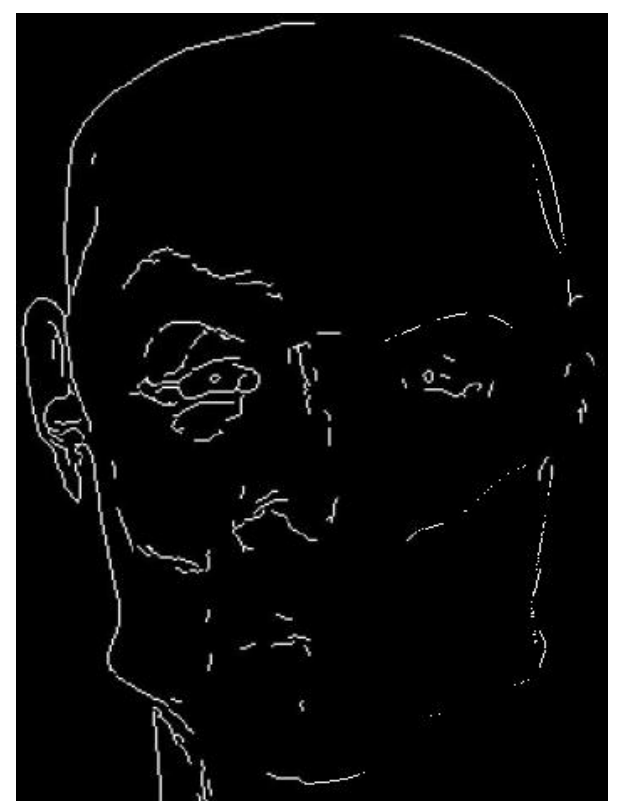

Figura 5.16: Pré-Processamento

A Figura 5.17 mostra uma caricatura de uma face. É importante ressaltar que esta representação é um desenho desproporcional quando comparado à face humana original. 
Logo, o algoritmo de investigação biométrica classificou esta imagem como não-face, evidenciando, mais uma vez, a importância da proporção áurea existente na face humana.

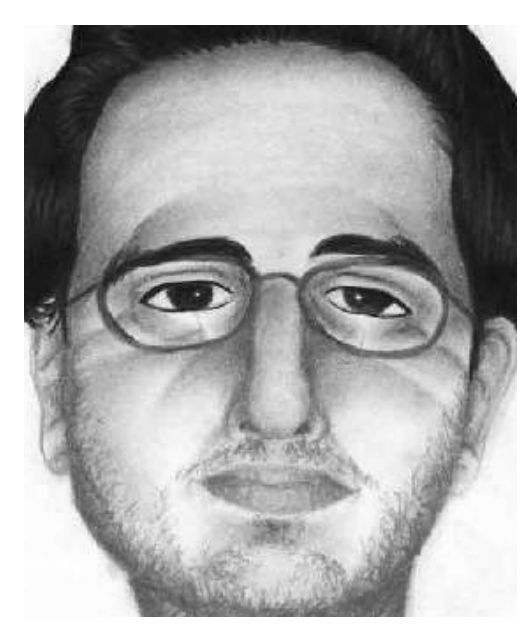

Figura 5.17: Imagem Original

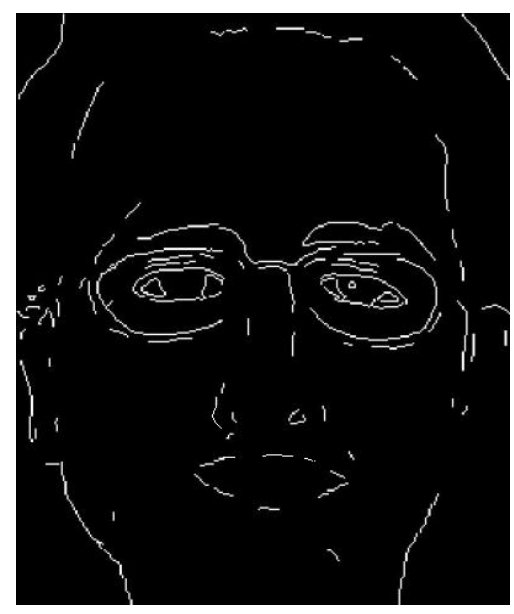

Figura 5.18: Pré-Processamento

A Figura 5.18 mostra o pré-processamento da imagem não-face. O baixo número de proporções divinas encontrado mostra a falta de proporção e conseqüente classificação como "não-face".

\subsection{Conclusões}

Pode-se observar através dos resultados apresentados que faces humanas podem ser detectadas e classificadas como tais a partir da investigação de Proporções Divinas. Este fato foi comprovado no desenvolvimento deste projeto ratificado em outras áreas de pesquisas como a ortodontia e a cirurgia plástica.

O uso da Proporção Divina como uma metodologia na área de detecção de faces humanas em imagens digitais é uma idéia inovadora e merece maiores investigações.

Através dos resultados apresentados nesta pesquisa conclui-se que a Proporção Divina é uma característica de grande capacidade de discriminação para a detecção de imagens de faces humanas reais. Salienta-se que os resultados obtidos assemelham-se aos demais resultados apresentados nas áreas que utilizam as formas geométricas para a detecção de faces, mas com um diferencial, ou seja, busca por faces reais e proporcionais. Figuras disformes, mesmo que representem faces humanas, terão baixa probabilidade de serem classificadas como tal. Este trabalho também comprova a existência de proporções áureas 
faciais que foram demonstradas por outros pesquisadores em outras áreas, tais como Ricketts (1982) e Oliveira Jr. (2000) na ortodontia e Maquardt (2001) na cirurgia plástica.

O algoritmo de investigação biométrica para detecção de faces humanas em imagens digitais usando lógica "fuzzy" apresentou um bom resultado quando submetido aos testes no banco de imagens de treinamento e no banco de imagens de teste ( $96 \%$ de acerto).

O desempenho do algoritmo de investigação biométrica validou-se através da confirmação da eficiência do mesmo nos dois bancos de imagens, apresentando um bom desempenho com uma baixa taxa de falso negativo e falso positivo. Nota-se também que o desempenho do algoritmo manteve-se constante, independentemente de qual dos dois bancos de imagens estava sendo utilizado.

Conclui-se finalmente que, a metodologia adotada permitiu comparar de maneira confiável o uso de proporções áureas e inferência "fuzzy" para se localizar uma face humana em uma imagem digital. Pode-se afirmar também que através de estudos específicos para outras formas naturais que possuem as proporções (Exemplo: o corpo humano, a mão humana, animais, etc.) a metodologia deverá ter um desempenho semelhante, pois as Proporções Divinas estarão presentes em cada uma delas.

\subsection{Propostas para Trabalhos Futuros}

Pelos resultados apresentados pode-se concluir que esta dissertação trouxe novas contribuições para área de visão computacional, instigando maiores explorações no desenvolvimento específico do tema. Algumas idéias são então propostas para o desenvolvimento de novos projetos.

A primeira seria a utilização de outras formas geométricas proporcionalmente áureas no processo de detecção de faces humanas. As seguintes formas não foram utilizadas na detecção: o triângulo áureo, o pentágono áureo e o decágono áureo. Assim, desenvolvendo um algoritmo que utilize os segmentos, triângulos, retângulos, pentágonos e decágonos áureos poder-se-ia aumentar consideravelmente o desempenho do sistema.

Uma segunda proposta seria a expansão dessa metodologia para detecção de faces humanas de perfil na cena.

Além disso, o que poderia significar realmente um maior avanço seria detectar em uma imagem geral regiões com probabilidades de serem faces humanas (Exemplo: usando a 
cor) e segmentar essas regiões para a investigação através da metodologia proposta neste trabalho. 
ALEJANDRE, S. (2003). How "Phi" is My Face?. Disponível em:<http://mathforum.org/te/alejandre/image.cursor/lesson2.html >. Acesso em: 21 Aug. 2003.

ATLANTIC OCEANOGRAPHIC AND METEOROLOGICAL LABORATORY (2001). Disponível em:<http://www.aoml.noaa.gov/hrd/>. Acesso em: 21 Aug. 2003.

BANKER, T. The Biological connection and the divine proportion. Disponível em:< http://jwilson.coe.uga.edu/emt669/student.folders/banker.teresa/golden/goldbiol.html> Acesso em: 21 Aug. 2003.

BEARDSLEY, M.C. (1966). Aesthetics from Classical Greece to the Present. New York Macmillan, p.43.

BEUS, H.L.; TIU, S.S. (1987). An improved corner detection algorithm based on chain-coded plane curves. Pattern Recognition, v.20, p.291-296.

BONVENTI Jr., W.; COSTA, A. H. R. (2000). Comparação entre métodos de definição de conjuntos nebulosos de cores para classificação de pixels. In: 1st. Workshop on Artificial Intelligence and Computer Vision, (parallel to IBERAMIA'2000-SBIA'2000) - Atibaia - Brasil.

CAI, J.; GOSHTASBY, A. (1999) - Detecting faces in color images. Image and Vision Computing, Guildford, v.18, n.1, p.63-75, Dec.

CARPENTER, R. (1959). The Esthetic Basis of Greek Art. Bloomington: Indiana University Press. p.92-93. 
CENTRO FEDERAL DE EDUCAÇÃO TECNOLÓGICA DO

PARANÁ. Unidade de Ponta Grossa (2002). Matemática. Disponível em:<http://www.pg.cefetpr.br/matemat/mate.htm>. Acesso em: 21 ago. 2003.

CHARLTON, R. (1998). Elements of design - proportion. Disponível em:<http://www.tcm.rmit.edu.au/notes/GoldenMean/>. Acesso em: 21 Aug. 2003.

CHELLAPPA, R.; WILSON, C.L.; SIROHEY, S. (1995). Human and Machine Recognition of Faces: A Survey. Proceedings of the IEEE, New York, vol.83, n.5, p.705-741, May.

CHEN, Q.; WU, H.; YACHIDA, M. (1995). Face detection by fuzzy pattern matching. In: INTERNATIONAL CONFERENCE ON COMPUTER VISION, 5., 1995, Cambridge. Proceedings... New York: IEEE. p.591-596.

COOTES, T.F.; TAYLOR, C.J. (1996). Locating faces using statistical feature detectors. In: INTERNATIONAL CONFERENCE ON AUTOMATIC FACE AND GESTURE RECOGNITION, 2., 1996, Killington. Proceedings... New York: IEEE. p.204-209.

COXETER, H.S.M. (1961). Introduction to geometry. London: John Wiley.

DAWSON, B. (2001). Biometrics measures physical traits. Vision Systems Design. Disponível em:<http://vsd.pennnet.com/home.cfm>. Acesso em: 21 Aug. 2003.

DAI, Y.; NAKANO, Y. (1996). Face-texture model based on SGLD and its applications in face detection in a color scene. Pattern Recognition, Oxford, v.29, n.6, p.1007-1017, June.

EDUARDO, J.V.P. (2000). Estudo da dimensão vertical de oclusão e do plano de orientação aplicando a proporção áurea. 141 p. Tese (Doutorado) - Faculdade de Odontologia, Universidade de São Paulo, São Paulo, 2000.

FRAKAS, L.G.; MUNRO, I.R. (1987). Anthropometric Facial Proportions in Medicine. Charles C. Thomas, Spring-field, IL.

FERIS, R.S; CAMPOS, T.E; CESAR Jr., R.M. (2000). Detection and tracking of facial features in video sequences. In Lecture Notes in Artificial Intelligence, v. 1793, p. 127-135, Acapulco, Mexico. Springer-Verlag Press.

FRANÇA, C.A. (1999). Avaliação da qualidade de placas de madeira através de um sistema de inferência nebuloso baseado em redes adaptativas. $135 \mathrm{p}$. Tese (Doutorado) - Instituto de Física de São Carlos, Universidade de São Paulo, São Carlos, 1999. 
GIOVANINI, R. (1998). Introdução às redes neurais. São Carlos: EESC/USP.

GOLDEN RATIO ACTIVITY. Disponível em:<http://www.markwahl.com/golden-ratio.htm>. Acesso em: 21 Aug. 2003.

GOLDEN RECTANGLE (1999). Disponível em:<http://www.q-net.net.au/ lolita/symmetry.htm>. Acesso em: 21 Aug. 2003.

GONZALEZ, R.C.; WOODS, R.E. (2000). Processamento de imagens digitais. São Paulo: Edgard Blücher.

GOVINDARAJU, V. (1996). Locating human faces in photographs. Int. J. Comput. Vision, v.19.

GUTHRIE, W.K.R. Pitágoras y los Pitagóricos, História de la Filosifia Griega. Tomol, Ed. Gredos, Madrid, p.215, s.d.

HJELMAS, E. (2001). Face Detection: A survey. Computer Vision and Image Understanding, v.83, p.236-274.

HUNTLEY, H.E. (1970). The Divine proportion: a study in mathematical beauty. New York: Dover Publications.

INTRO the golden proportion. (1998). Disponível em:<http://www.heartbeat2000.com/phi.htm>. Acesso em: 21 Aug. 2003.

JENG, S.H.; LIAO, H. Y. M.; HAN, H. Y. M.; CHERN, M. Y.; LIU, Y. T. (1998). Facial feature detection using geometrical face model: An efficient approach. Pattern Recognition, v.31, n.6, p.273-282.

KIM, H.S.; KIM, E.Y.; HWANG, S.W.; KIM, H.J. (2000). Object-based human face detection. Consumer Electronics, 2000. ICCE. International Conference on 13-15 June, p.354-355.

KLIR, G.J.; YUAN, B. (1995). Fuzzy sets and fuzzy logic - theory and applications. New Jersey: Prentice Hall PTR.

KNAPP, R.B. (1996). Fuzzy sets and pattern recognition. Disponível em:<http://www-engr.sjsu.edu/ Knapp/HCIFUZZY/fuzzy.htm>. Acesso em: 20 Feb. 2003.

KNOTT, R. (2003). Fibonacci numbers and nature - part 2 why is the golden section the "best" arrangement?. Disponível 
em:<http://www.mcs.surrey.ac.uk/Personal/R.Knott/Fibonacci/fibnat2.html>. Acesso em: 21 Aug. 2003.

KNOTT, R. (2003). Fibonacci numbers and the golden section. Disponível em:<http://www.mcs.surrey.ac.uk/Personal/R.Knott/Fibonacci/fib.html>. Acesso em: 21 Aug. 2003.

LEE, C.C. (1990a). Fuzzy logic in control systems: fuzzy logic controller - part I. IEEE Transactions on Systems, Man and Cybernetics, New York, v.20, n.2, p.404-418, Mar./Apr.

LEE, C.C. (1990b). Fuzzy logic in control systems: fuzzy logic controller - part II. IEEE Transactions on Systems, Man and Cybernetics, New York, v.20, n.2, p.419-435, Mar./Apr.

LEVIN, E. The Golden proportion. Disponível em:<http://www.goldenmeangauge.co.uk/golden.htm>. Acesso em: 21 Aug. 2003.

LÓGICA Fuzzy. Disponível em:<http://bigbob.sites.uol.com.br/fuzzy_4.htm>. Acesso em: 21 Aug. 2003.

MARQUARDT, S.R. (2001). Marquardt Beauty Analysis California. Disponível em:<http://www.beautyanalysis.com/index2_mba.htm>. Acesso em: 02 Sep. 2003.

MATSUMOTO, E.Y. (2001). Matlab 6 - fundamentos de programação. São Paulo: Érica.

MCNAMARA, A.; MCDONNELL, R. In The Eye of the beholder?. Disponível em:<http://www.cs.tcd.ie/people/Ann.McNamara/proj5.html>. Acesso em: 21 Aug. 2003.

MEDIONI, G.; YASUMOTO, Y. (1987). Corner detection and curve representation using cubic B-splines. CVGIP, v.39, p.267-278.

MOREIRA, J. (1999). Uma Proposta de estruturação e integração de processamento de cores em sistemas artificiais de visão. 285 p. Tese (Doutorado) - Instituto de Física de São Carlos, Universidade de São Paulo, São Carlos, 1999.

OLIVEIRA JR., O.B. (2000). Construtores de sorriso - ciência ou arte?. Disponível em: $\langle$ http://www.apcdriopreto.com.br/art_cientificos2.asp?codigo=6>. Acesso em 21 ago. 2003. 
PANOFSKY, E. (1976). Significado nas artes visuais. São Paulo: Perspectiva. v.3, p.101.

PHI - the golden number. (1999). Disponível em:<http://goldennumber.net/>. Acesso em: 21 Aug. 2003.

PICCIN, M.R. (1997). Verificação da proporção divina da face em pacientes totalmente dentados. 42, 43, 44 p. Dissertação (Mestrado) - Faculdade de Odontologia de Piracicaba, Universidade Estadual de Campinas, Piracicaba, 1997.

PICS. Psychological Image Collection at Stirling. Disponível em:<http://pics.psych.stir.ac.uk/>. Acesso em: 27 Oct. 2004.

POWELL, N.; HUMPHREYS, B. (1984). Proportions of the aesthetic face. New York: Thieme-Stratton. (Serie Sponsored by the Educatiional Committee of the American Academy of Facial Plastic and Reconstructive Surgery).

PROPORÇÃO Áurea. (2003). Disponível em:<http://www.mat.uel.br/geometrica/4tarq.htm>. Acesso em: 21 Ago. 2003.

PROPORTIONS: theorie and construction golden section or golden mean, modulor, square root of two. (1997). Disponível em:<http://home.att.net/ vmueller/prop/theo.html\#gs>. Acesso em: 21 Aug. 2003.

RANULFO, A. (2002). Web templarios. Disponível em:<http://www.geocities.com/templosalomao/pi.htm>. Acesso em: 21 Aug. 2003.

RICKETTS, R.M. (1981). The Golden divider. Journal of Clinical Orthodontics, Hempstead, v.15, n.11, p.752-759, Nov.

RICKETTS, R.M. (1982). The Biologic significance of the divine proportion and fibonacci series. American Journal of Orthodontics, St.Louis, v.81, n.5, p.351-370, May.

ROSS, K.L. (1999). The Golden ratio and the fibonacci numbers. Disponível em:<http://www.friesian.com/golden.htm\#text-2>. Acesso em: 21 Aug. 2003.

ROWLEY, H.A.; BLUJA, S.; KANADE, K. (1998). Neural network-based face detection. IEEE Transactions on Pattern Analysis and Machine Intelligence, New York, v.20, n.1, p.23-38, Jan.

SABER, E.; TEKALP, A. M. (1998). Front view-face detection and facial feature extraction using color, shape and symmetry based cost functions. Pattern Recognition Letters, v.19, n.8, p. 669-680. 
SAMAL, A.; IYENGAR, P.A. (1992). Automatic recognition and analysis of human faces and facial expressions: a survey. Pattern Recognition, Oxford, v.25, n.1, p.65-77, Jan.

SECÇÃO áurea na geometria. Disponível em:<http://7mares.terravista.pt/matcad/AngNunLp/desenvolvimento/secgeo.htm>. Acesso em: 21 ago. 2003.

SILVA, A.P.; ANDRADE, I.; PEPINO, C. Número de Ouro. Disponível em:<http://www.educ.fc.ul.pt/icm/icm99/icm17/ouro.htm>. Acesso em: 21 ago. 2003.

SOBOTTKA, K.; PITAS, I. (1996). Segmentation and tracking of faces in color images. In: INTERNATIONAL CONFERENCE ON AUTOMATIC FACE AND GESTURE RECOGNITION, 2., 1996, Killington. Proceedings... New York: IEEE. p.236-241.

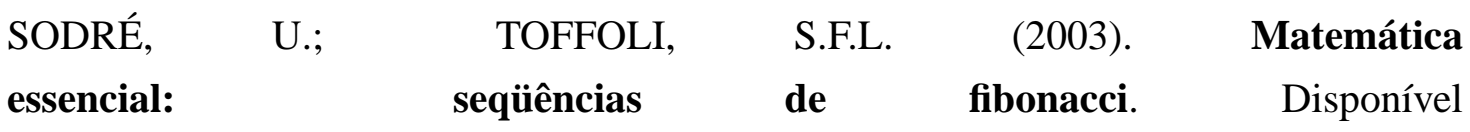
em: $<$ http://pessoal.sercomtel.com.br/matematica/alegria/fibon/seqfib1.htm>. Acesso em: 21 ago. 2003.

SUNG, K.K.; POGGIO, T. (1998). Example-based learning for view-based human face detection. IEEE Transactions on Pattern Analysis and Machine Intelligence, New York, v.20, n.1, p.39-51, Jan.

THE GOLDEN mean. (1998). Disponível em:<http://www.vashti.net/mceinc/golden.htm>. Acesso em: 21 Aug. 2003.

THE GOLDEN ratio project. (1999). Disponível em:<http://www.geocities.com/capecanaveral/station/8228/index.htm>. Acesso em: 21 Aug. 2003.

THE GOLDEN section ratio: phi. (2003). Disponível em:<http://www.mcs.surrey.ac.uk/Personal/R.Knott/Fibonacci/phi.html>. Acesso em: 21 Aug. 2003.

THE NAUTILUS and the human embryo. (1999). Disponível em:<http://www.geocities.com/capecanaveral/station/8228/spiral.htm>. Acesso em: 21 Aug. 2003.

THE HUMAN face. (1999). Disponível em:<http://goldennumber.net/face.htm>. Acesso em: 21 Aug. 2003. 
WANG, J.; TAN, T. (2000). A new face detection method based on shape information.

Pattern Recognition Letters, v.21, p.463-471.

WEI, G.; SETHI, K. (1999). Face detection for image annotation. Pattern Recognition Letters, v.20, p.1313-1321.

YACHIDA, M.; WU, H.; CHEN, Q. (1999). Face Detection From Color Images Using a Fuzzy Pattern Matching Method. IEEE Transactions on Pattern Analysis and Machine Intelligence, v.21, n.6, p.557-563, Jun.

YANG, G.; HUANG, T. (1994). Human face detection in a complex background. Pattern Recognition, Oxford, v.27, n.1, p.53-63, Jan.

YOW, K.C.; CIPOLLA, R. (1997). Feature-based human face detection. Image and Vision Computing, Guildford, v,15, n.9, p.713-735, Sept.

ZADEH, L.A. (1965). Fuzzy sets. Information and Control, New York, v.8, n.3, p.338-353. 


$\bar{A}$

\section{Apêndice - Exemplos de Proporção Divina}

Este apêndice visa uma melhor explanação da Proporção Divina. Inicialmente, é detalhado o funcionamento do Medidor de Proporção Divina, o qual é muito utilizado na maioria dos exemplos contido neste texto.

\section{A.1 O Medidor de Proporção Divina}

Para examinar a validade da fascinante proporção divina de maneira rápida e fácil, um instrumento, o Medidor de Proporção Divina, é utilizado para demonstrar esta proporção (LEVIN, s.d.), conforme mostra a Figura A.1. 


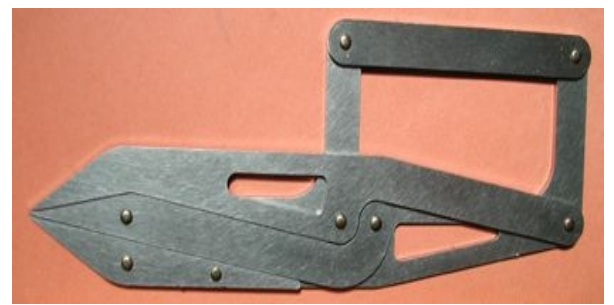

Figura A.1: Medidor de Proporção Divina

Este medidor realiza a medida de forma que a maior abertura mede 1.618 e a menor mede 1, conforme mostra a Figura A.2. Dessa maneira, consegue-se detectar a Proporção Divina em vários objetos com precisão de 0.25 milímetros.

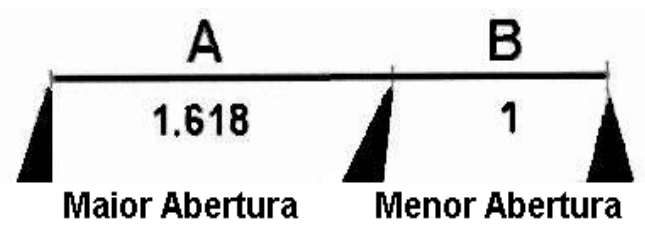

Figura A.2: Realização da medição

O medidor, como visto na figura A.3, mostra que as numerosas marcas principais na asa da mariposa estão em proporção divina.
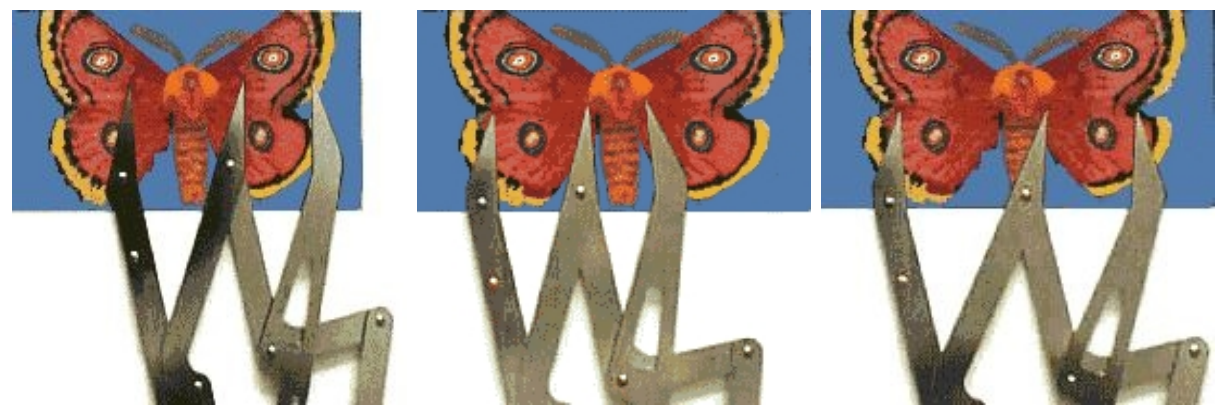

Figura A.3: Medidor sendo utilizado para verificação da Proporção Divina na mariposa 


\section{A.2 Exemplos de Proporção Divina na Natureza}

Esta seção contém exemplos destinados a uma melhor compreensão da Proporção Divina na Natureza, citadas na seção 2.4. Estes exemplos são:

- a disposição de sementes de pólen em uma flor (Figura A.4);
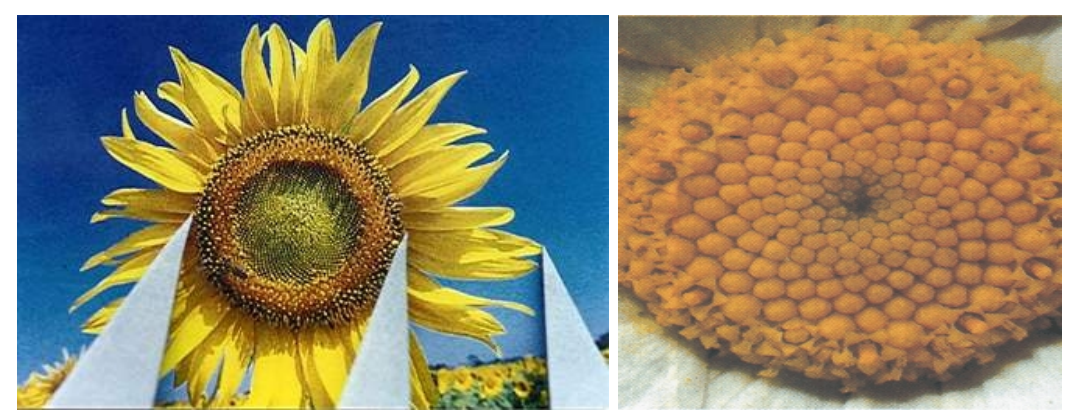

Figura A.4: Verificação da Proporção Divina em um Girassol

- o arranjo foliar (Figura A.5);
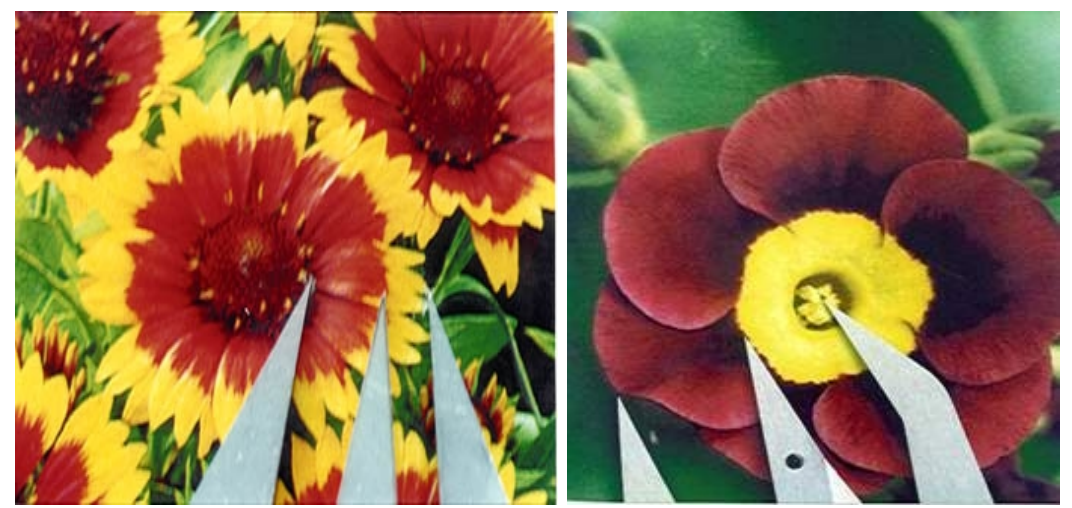

Figura A.5: Verificação da Proporção Divina em Flores 
- o crescimento de ramos nos meristemas vegetais (Figura A.6);

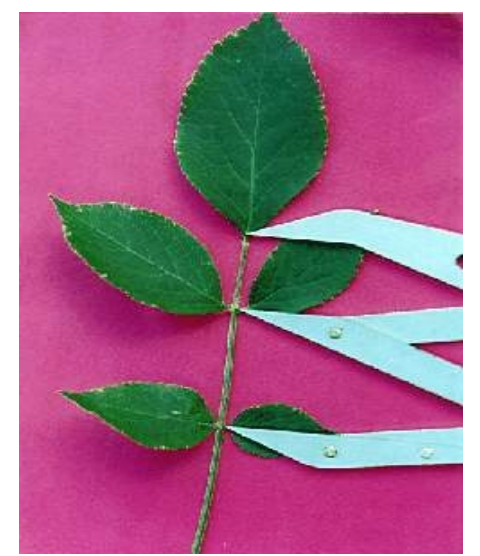

Figura A.6: Verificação da Proporção Divina em um Ramo

- as ondas do mar e os peixes (Figura A.7);
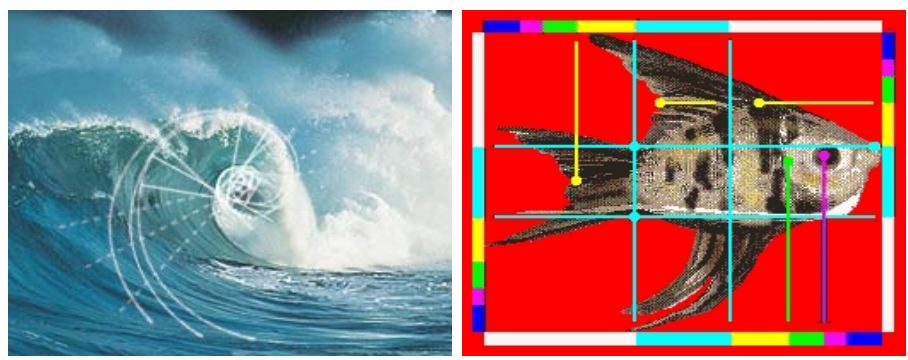

Figura A.7: Verificação da Proporção Divina nas Ondas do Mar e em Peixes

- as conchas de moluscos marinhos (Figura A.8);
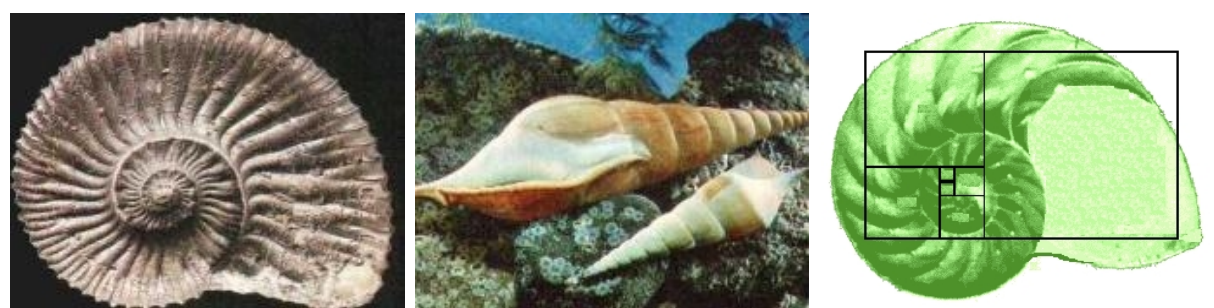

Figura A.8: Verificação da Proporção Divina em Moluscos Marinhos 
- os insetos (Figura A.9);

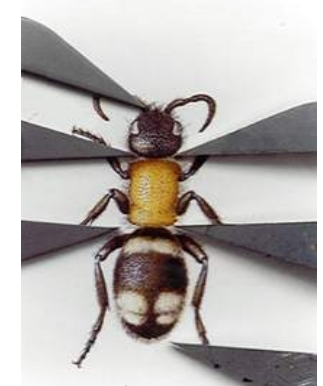

Figura A.9: Verificação da Proporção Divina em Insetos

- as disposições das cores nos corpos dos animais (Figura A.10);
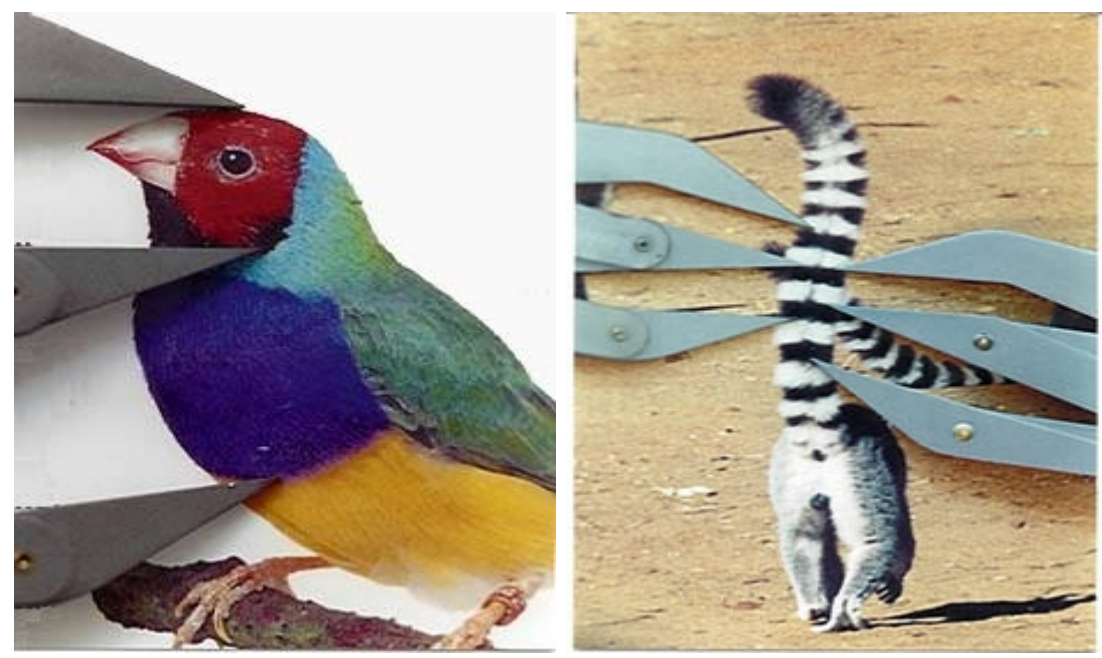

Figura A.10: Verificação da Proporção Divina nas cores de corpos de diversos animais 
- em faces de tigres (Figura A.11);
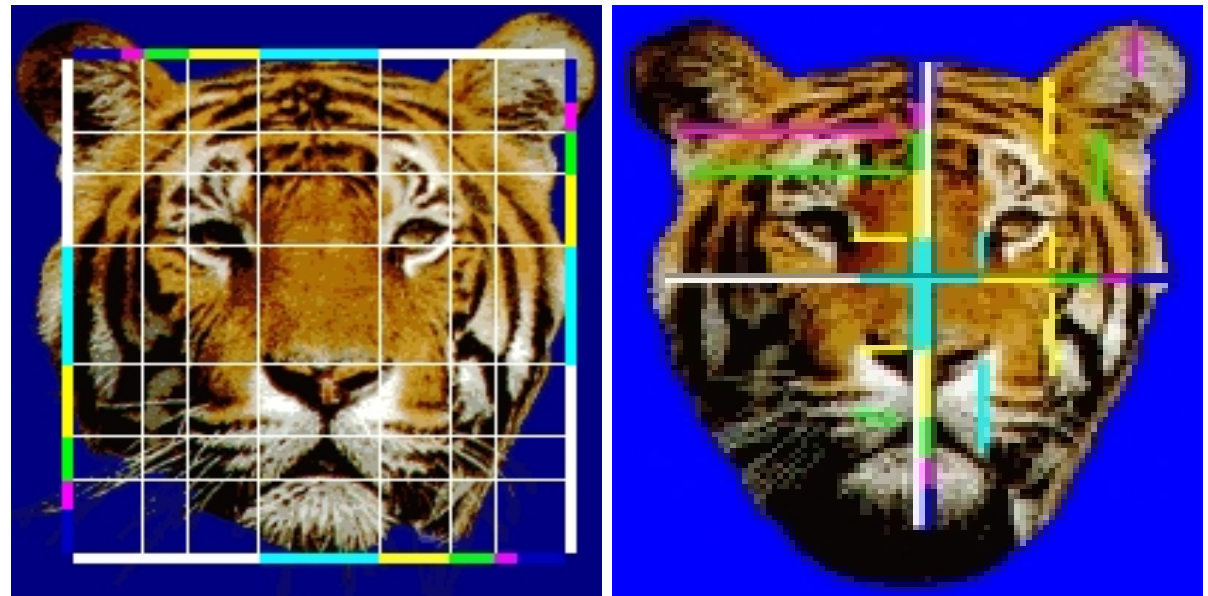

Figura A.11: Verificação da Proporção Divina em Face de Tigres

- no corpo de golfinhos e pingüins (Figura A.12);
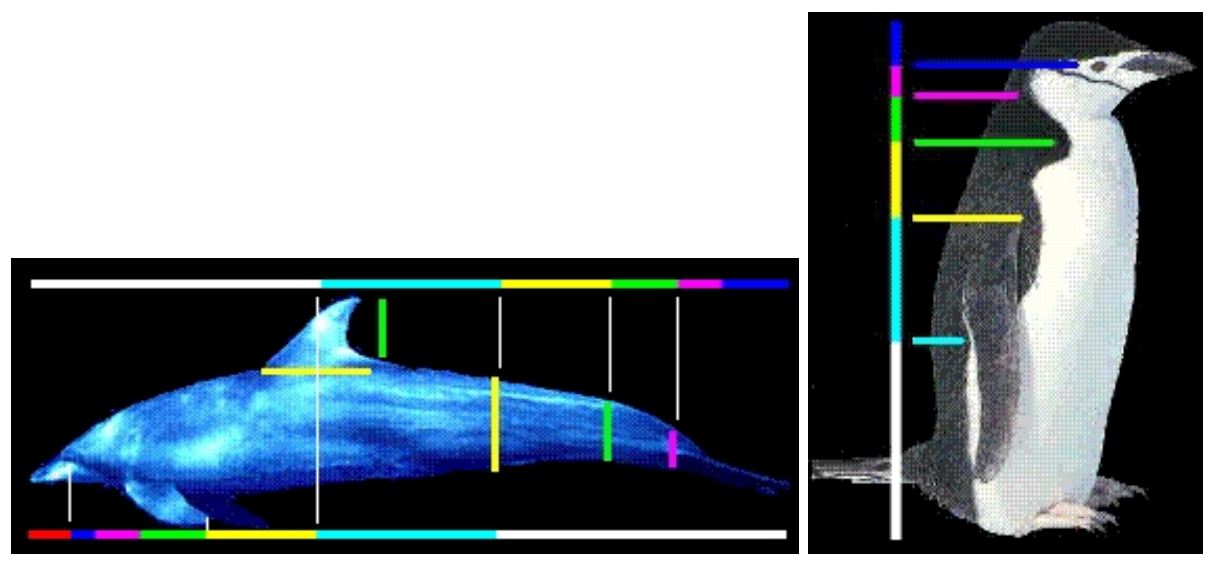

Figura A.12: Verificação da Proporção Divina no Corpo de Golfinhos e Pingüins 


\section{A.3 Exemplos de Proporção Divina na Indústria}

Os exemplos que demonstram a presença de Proporção Divina na Indústria são:

- o "design" do carro (Figura A.13);

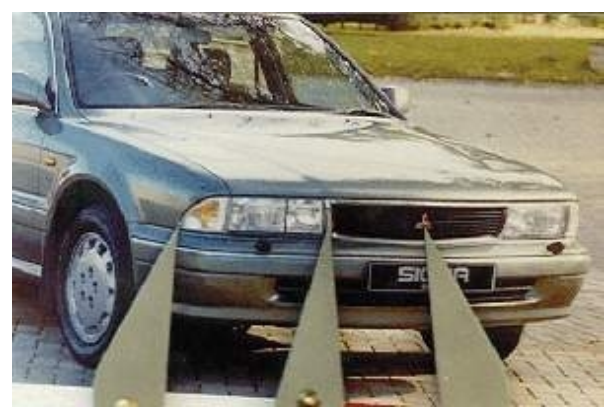

Figura A.13: Verificação da Proporção Divina no Carro

- o CD (“Compact Disc”) (Figura A.14);

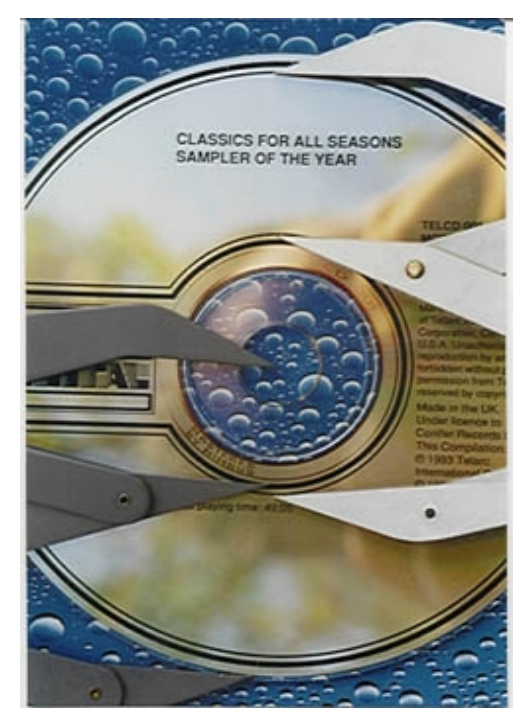

Figura A.14: Verificação da Proporção Divina no CD 
- a torneira (Figura A.15);

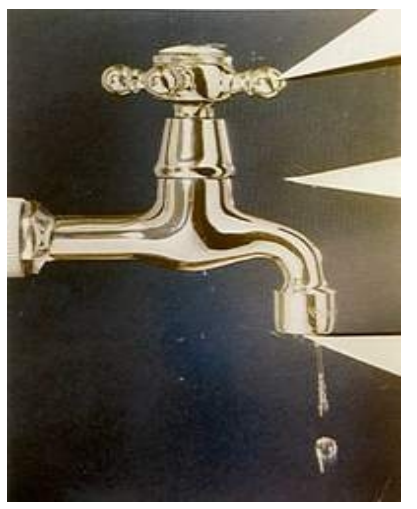

Figura A.15: Verificação da Proporção Divina na Torneira

- o violino (Figura A.16);

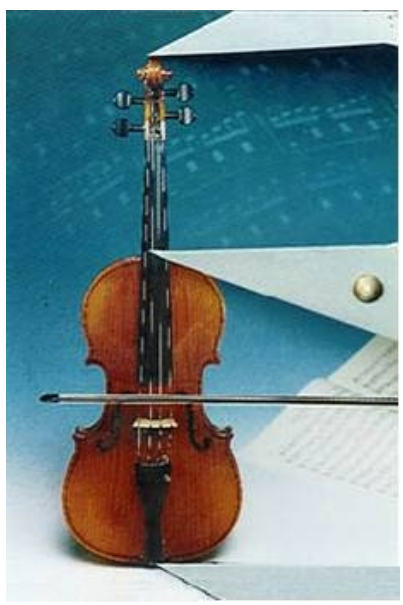

Figura A.16: Verificação da Proporção Divina no Violino 


\section{A.4 Exemplos de Proporção Divina na Arquitetura}

Alguns exemplos de Proporção Divina encontrados na Arquitetura, são eles:

- o portão da cidade de Bagdá (Figura A.17);

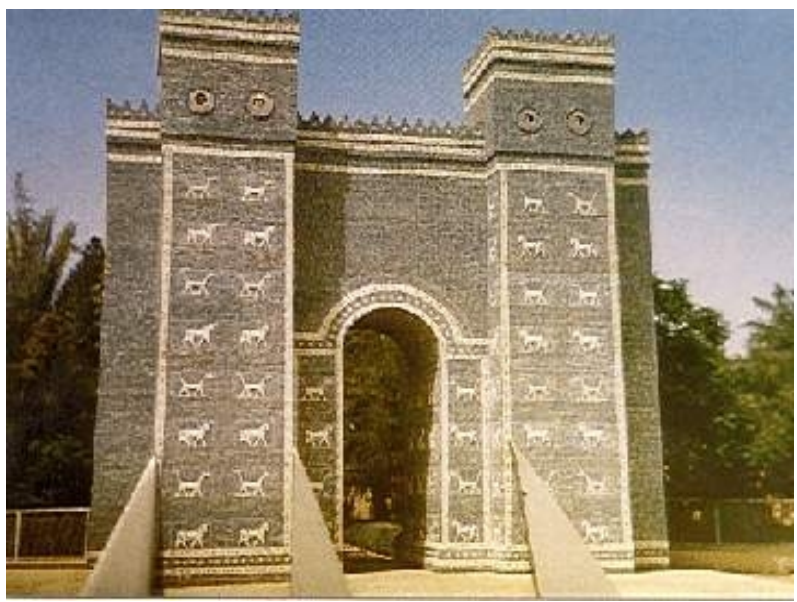

Figura A.17: Verificação da Proporção Divina no Portão da Cidade de Bagdá

- a Grande Muralha da China (Figura A.18);

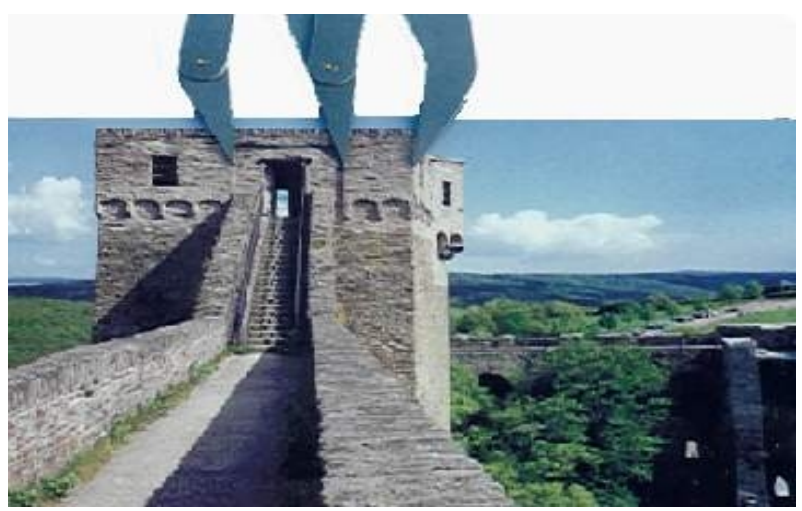

Figura A.18: Verificação da Proporção Divina na Grande Muralha da China 
- na Catedral de Notre Dame (Figura A.19);

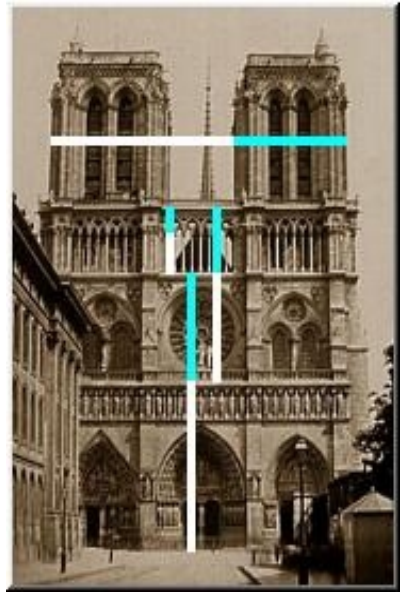

Figura A.19: Verificação da Proporção Divina na Catedral de Notre Dame 


\section{Apêndice - A Proporção Áurea e Estruturas Adjacentes}

\section{B.1 Secção Áurea}

A Secção Áurea é denominada também razão áurea (PROPORÇÃO, 2003). Diz-se que o ponto $\mathrm{B}$ divide o segmento $\mathrm{AC}$ em média e extrema razão, conforme mostra a Figura B.1. Se a razão entre o menor e o maior dos segmentos é igual à razão entre o maior e o segmento todo, isto é , $\mathrm{AB} / \mathrm{BC}=\mathrm{BC} / \mathrm{AC}$.

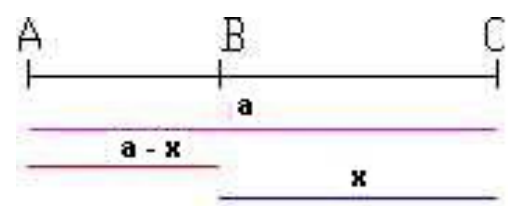

Figura B.1: Razão Áurea 
Usando a notação matemática, conforme na Figura B.1, pode-se escrever esta relação através da Equação (1):

$$
\frac{(a-x)}{x}=\frac{x}{a}
$$

A raiz positiva $1,618034 \ldots$, muitas vezes é indicada pelo símbolo $\Phi$ (lê-se: fi) e algumas vezes por $\tau$ (lê-se: tau).

\section{B.2 Segmento Áureo}

O Segmento Áureo é também chamado de segmento de ouro ou número de ouro (PROPORÇÃO, 2003)(Figura B.2). Pode-se defini-lo da seguinte forma:

1. é o segmento resultante da divisão de um outro segmento $A B$ em média e extrema razão, ou seja, é obtido quando se faz uma secção áurea no segmento $\mathrm{AB}$.

2. quando se quer obter o segmento áureo $a$ de outro segmento dado $A B$, basta multiplicar $\overline{A B}$ por $1 / \Phi$.

3. quando se quer obter o segmento $\mathrm{AB}$ onde $a$ é o segmento áureo, basta multiplicar $\overline{A B}$ por $\Phi(\Phi=$ número de ouro).

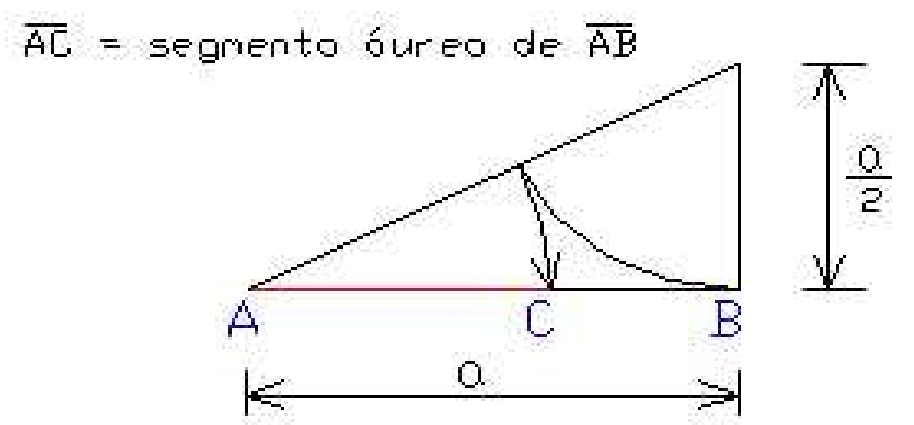

Figura B.2: Segmento Áureo 


\section{B.3 Número de Ouro}

O Número de Ouro é também chamado de razão áurea, secção áurea, segmento áureo, proporção áurea e proporção divina; é simbolizado pela letra $(\Phi)$ inicial do nome de Fídias, escultor grego que utilizou este número nas suas obras (PROPORÇÃO, 2003). Este número é:

1. o número obtido quando se divide $a$ por $b$, onde $a$ e $b$ são duas grandezas, sendo que, $a$ é uma grandeza maior do que $b$ :

$$
\begin{gathered}
\frac{(a+b)}{a}=\frac{a}{b}=\Phi=1,618034 \\
\Phi^{2}=2,618 \\
\frac{1}{\Phi}=0,618034
\end{gathered}
$$

Esta proporção diz que a relação entre a soma dessas duas grandezas, e a maior delas (que no caso é $a$ ), é igual à relação entre $a$ e a outra $b$. Isto de fato se obtém quando $a=1,618$, que é o número de ouro. Portanto 1,618 é a razão entre os termos da proporção.

2. o único número positivo que satisfaz a relação $\Phi^{2}=1+\Phi$.

3. a igualdade $\Phi=2 \cos (\Phi)$ implica a presença do número de ouro em muitas proporções. Exemplos: entre os elementos de polígonos regulares, tais como, pentágonos, decágonos, estrelas pentagonais e decágonos.

4. o número $\Phi$ aparece nas artes; no pentágono regular estrelado; no corpo humano; nos animais; nas flores; na formação das árvores; na disposição das folhas em certas plantas; nos frutos; na espiral logarítmica; na construção do decágono regular; na construção do pentágono regular; em vários poliedros regulares; na pirâmide de Queops; nas danças clássicas; nas grandes catedrais da Idade Média; na arquitetura; no "modulor" de Le Corbusier; na poesia; na sequiência de Fibonacci; entre outros. 


\section{B.4 Retângulo Áureo}

Retângulo Áureo é o retângulo que tem os seus lados $a$ e $b$ na razão áurea $\mathrm{a} / \mathrm{b}=\Phi$ $=1,618034$, portanto, o lado menor $b$ é o segmento áureo do lado maior $a$ (Figura B.3 e B.4).

O retângulo áureo exerceu grande influência na arquitetura grega. As proporções do Parthenon testemunham desta influência. Construído em Atenas, no século V a.C., o Parthenon é considerado uma das estruturas mais famosas do mundo. Quando seu frontão triangular ainda estava intacto, suas dimensões podiam ser encaixadas quase exatamente em um retângulo áureo (PROPORÇÃO, 2003).

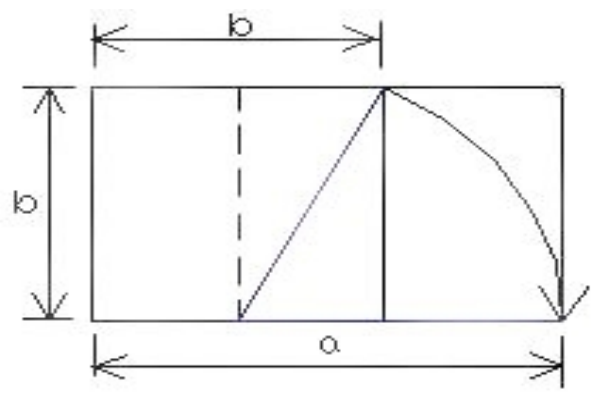

Figura B.3: Construção do retângulo áureo, sendo dado o seu lado menor $b$

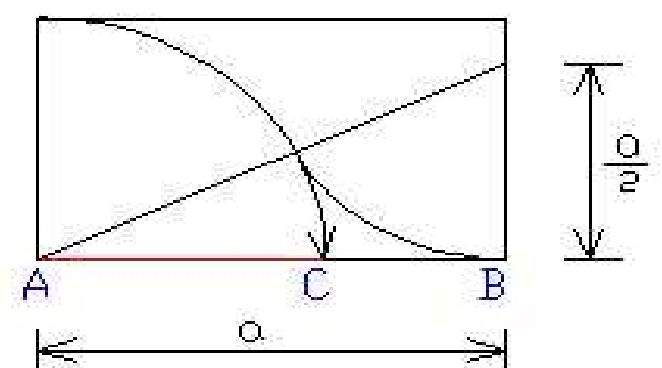

Figura B.4: Construção do retângulo áureo, sendo dado o seu lado maior $a$ 


\section{B.5 Pentagrama}

Pentagrama: do grego - pénta (cinco) + gramma (linha); símbolo da saúde e a insígnia que identificava os pitagóricos, este é um pentágono regular estrelado, no qual cada um dos cinco segmentos divide outros em média e extrema razão (PROPORÇÃO, 2003). $\mathrm{O}$ ponto de intersecção $\mathbf{P}$ de duas diagonais divide cada uma delas na proporção áurea. $\mathbf{P}$ divide $\overline{A Q}$ e $\overline{A B}$ internamente e $\overline{Q B}$ externamente nessa proporção, conforme mostra a Figura B.5 .
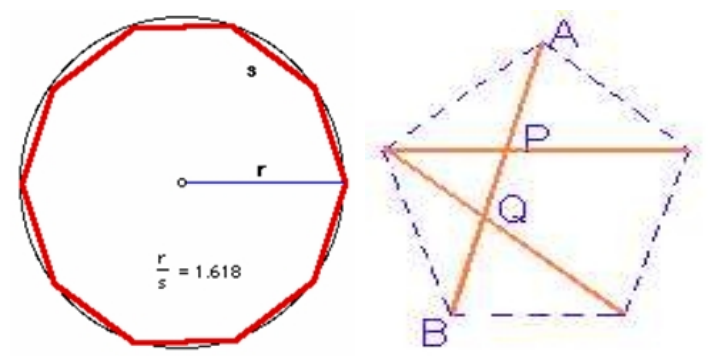

Figura B.5: Decágono e o pentagrama, respectivamente

Um fato conhecido dos antigos geômetras era que a razão do raio do círculo de um decágono regular para um dos lados é a razão áurea.

\section{B.6 Triângulo Áureo}

O triângulo áureo é um triângulo isósceles $\mathrm{ABC}$ com ângulos da base de $72^{\circ}$ e ângulo do ápice de $36^{\circ}$. Este é encontrado no "pentagrama místico". A partir do triângulo áureo podemos desenhar uma espiral logarítmica (Figura B.6). 


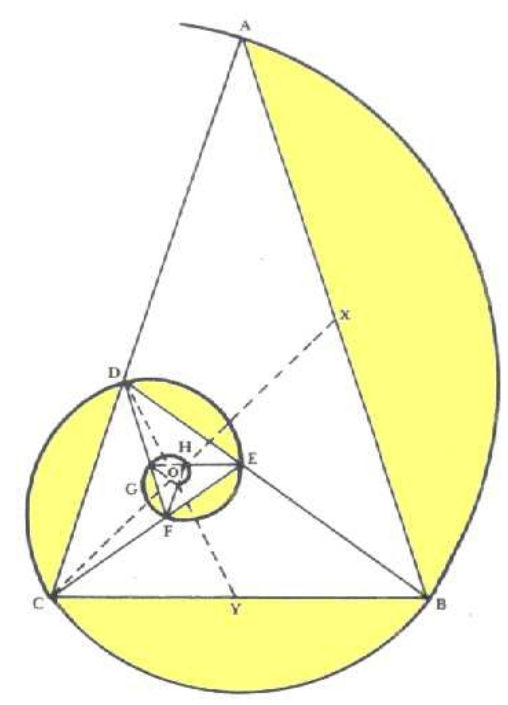

Figura B.6: Triângulo Áureo

\section{B.7 Seqüência de Fibonacci}

Em sua obra "Liber Abaci”, Fibonacci apresentou um quebra cabeça matemático que deu origem à Seqüência de Fibonacci relacionada com solução do Problemas dos Pares de Coelhos. Esta sequiência segue a regra segundo cada termo é a soma dos dois termos anteriores. Desta forma, encontramos o termo geral da seqüência de Fibonacci:

$$
u_{n+1}=u_{n}+u_{n-1}
$$

Por exemplo, se $u_{1}=1, u_{2}=1$, então temos a seguinte seqüência de Fibonacci: 1 , $1,2,3,5,8,13,21,34, \ldots$

Se tomarmos as razões de cada termo pelo seu antecessor, obteremos uma seqüência numérica, cujo termo geral é dado por:

$$
f_{n}=\frac{u_{n+1}}{u_{n}}
$$

Consideremos a mesma seqüência de Fibonacci e a divisão de cada número pelo seu antecessor, conforme a fórmula anterior, e obteremos a sequiência: 


$$
\frac{1}{1}=1, \frac{2}{1}=2, \frac{3}{2}=1,5, \frac{5}{3}=1,666 \ldots, \frac{8}{5}=1,6, \frac{13}{8}=1,625, \ldots
$$

As sucessivas razões entre um número e o que o antecede vão-se aproximando do número de ouro. É possível perceber o que ocorre quando colocamos estas razões num gráfico em função dos números de Fibonacci ${ }^{1}$, conforme pode ser visto na Figura B.7.

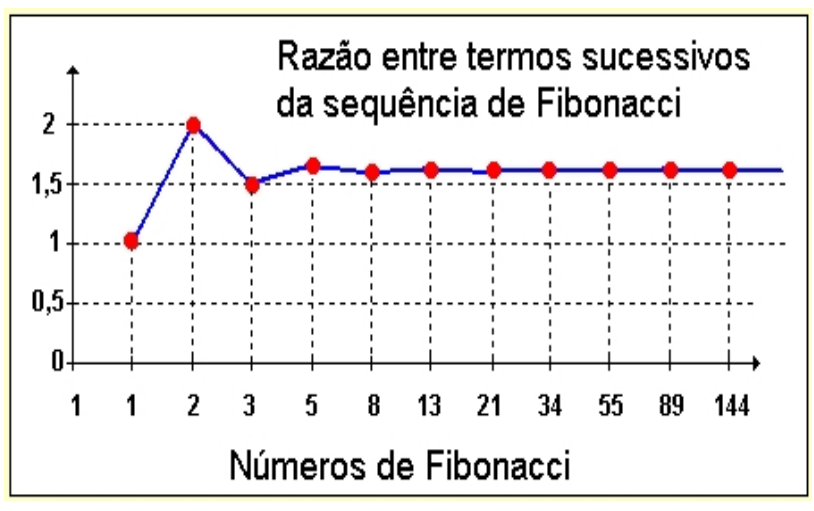

Figura B.7: Gráfico da Seqüência de Fibonacci

\section{B.8 Espiral Logarítmica}

A Espiral Logarítmica é também chamada de equiangular, devido cortar todos os raios vetores sob o mesmo ângulo; é uma curva gerada por um ponto que caminha em torno de um pólo. O ponto se desloca no raio vetor em progressão geométrica, enquanto o raio polar gira em torno do pólo em progressão aritmética, numa sucessão de ângulos iguais (PROPORÇÃO, 2003).

Na Figura B.8 e B.9 nota-se as seguintes características interessantes da espiral:

1. O ponto limite O é chamado de pólo da espiral, o qual passa pelas secções áureas $\mathrm{D}, \mathrm{E}, \mathrm{G}, \mathrm{J} .$.

2. As diagonais AC e BF são mutuamente perpendiculares.

3. Os pontos E, O, J são colineares, assim como G, O e D.

\footnotetext{
${ }^{1}$ Para maiores detalhes sobre a seqüência de Fibonacci e suas demais propriedades, veja informações contidas na referência SODRÉ, (2003).
} 
4. Os quatro ângulos retos do ponto O têm EJ e DG por bissetrizes.

5. $\mathrm{AO} / \mathrm{OB}=\mathrm{OB} / \mathrm{OC}=\mathrm{OC} / \mathrm{OF}=\ldots$ Há inumeráveis triângulos similares, cada um igual à metade de um retângulo áureo.

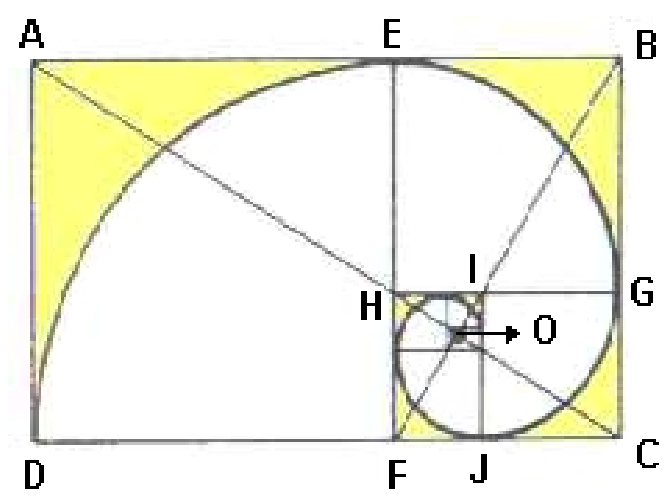

Figura B.8: Espiral Logarítmica

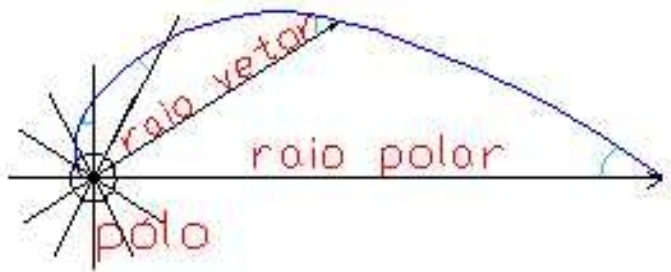

Figura B.9: Espiral Equiangular

\section{B.9 Modulor}

O "Modulor"desenvolvido pelo arquiteto francês Le Corbusier, significa a relação de medidas baseadas na divisibilidade do corpo humano em proporção harmônica (PROPORÇÃO, 2003), conforme pode ser visto na Tabela B.1. Assim, tem-se:

1. A partir da altura máxima de ocupação do espaço pelo corpo humano (distância do chão até as pontas dos dedos com o braço levantado) e da metade dessa altura (até o plexo solar) criou-se duas séries de valores em relação áurea, que são obtidas a partir da divisão harmônica destes comprimentos, os quais constituem uma gama de medidas humanas.

2. Na série estabelecida a partir da altura do plexo solar (a qual chamou série vermelha) o termo que sucede imediatamente coincide com a altura do homem (175 ou $183 \mathrm{~cm})$. O termo principal da série azul, altura do homem com o braço levantado (216 ou $226 \mathrm{~cm}$ ) coincide com a adição dos três termos principais da série vermelha. Pela combinação dos termos principais das duas séries obtêm-se os valores de ocupação do corpo humano.

3. A princípio Le Corbusier partiu da estatura média do homem da Europa $(175 \mathrm{~cm})$ para determinar os valores numéricos dos vários comprimentos. Os valores inferiores assim encontrados foram para a série vermelha e os valores exatos obtidos 
pela divisão harmônica foram depois arredondados, tendo-se obtido os chamados valores de aplicação.

4. Pode-se obter valores maiores a partir de $2.26 \mathrm{~cm}$, basta multiplicar por $\Phi=1,618034$.

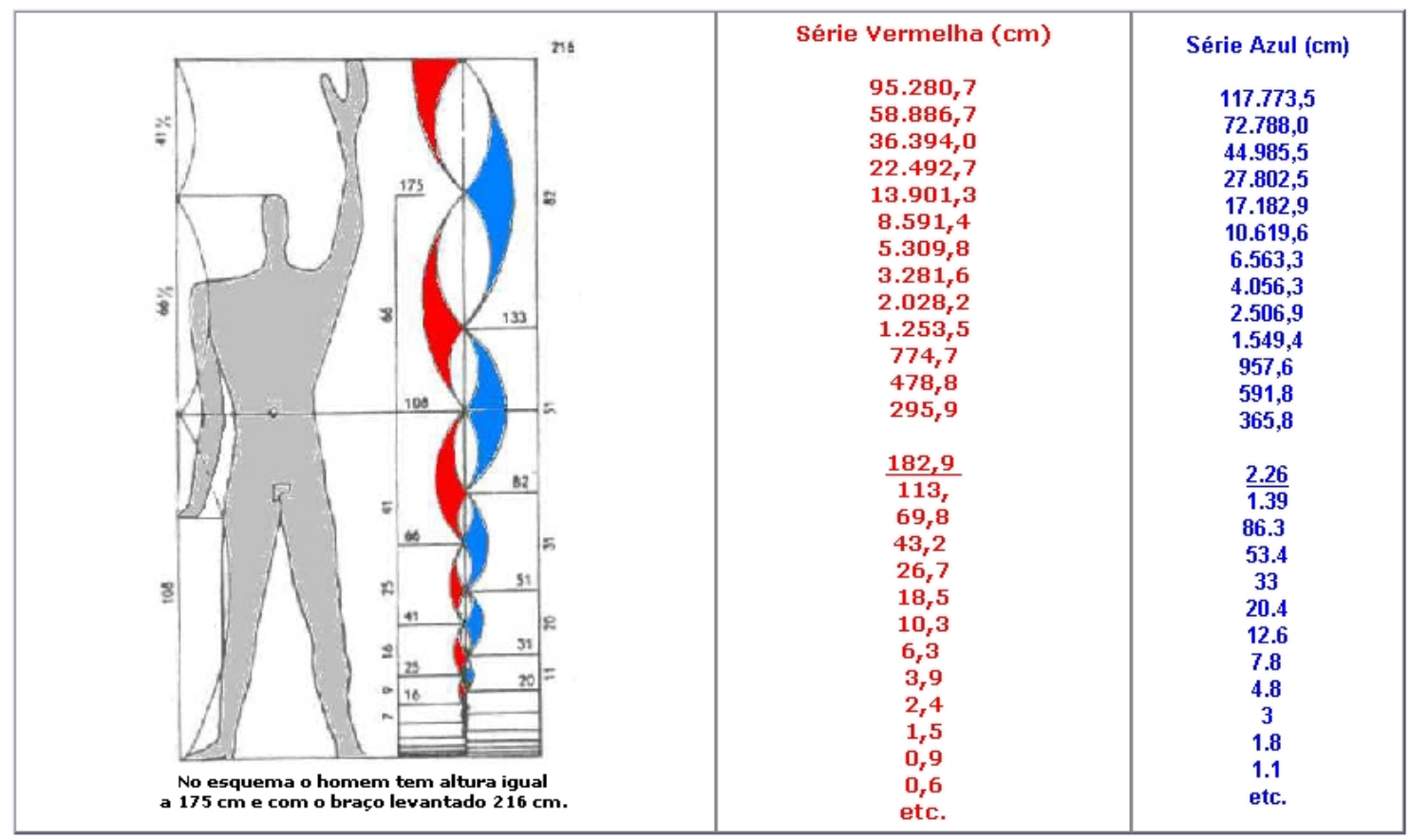

Tabela B.1: O "Modulor" 


$\longrightarrow$ APÊNDICE

\section{Apêndice - Resultados}

\section{C.1 Segmento Áureo Horizontal}

Os gráficos a seguir mostram o número de segmentos áureos horizontais detectados em cada uma das quatro regiões da imagem na etapa de extração de características.

Importante ressaltar também que todos os resultados mostrados nos gráficos foram obtidos nos testes realizados no banco de imagens de treinamento, sendo que o mesmo possui um total de 100 imagens, 51 faces de mulheres e 49 faces de homens. 
As Figuras C.1, C.2, C.3 e C.4 mostram os gráficos com o número de segmentos áureos horizontais obtidos pelo algoritmo nas 49 faces masculinas nas regiões 1, 2, 3, e 4 da imagem.

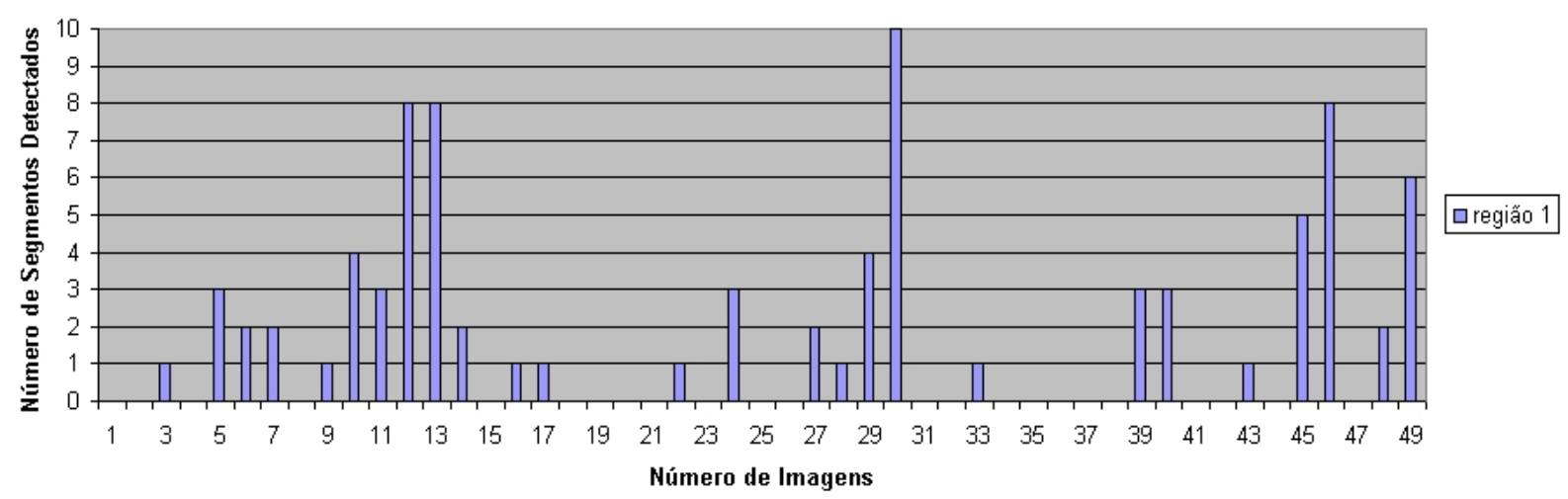

Figura C.1: Número de Segmentos Áureos Horizontais detectados nas faces

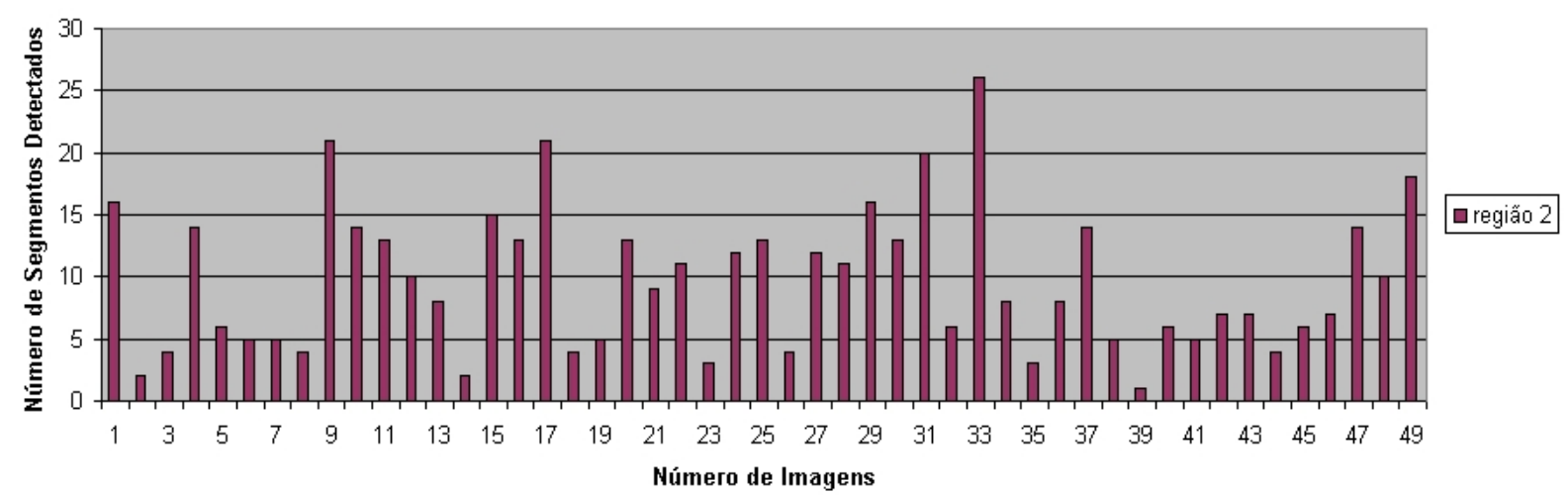

Figura C.2: Número de Segmentos Áureos Horizontais detectados nas faces

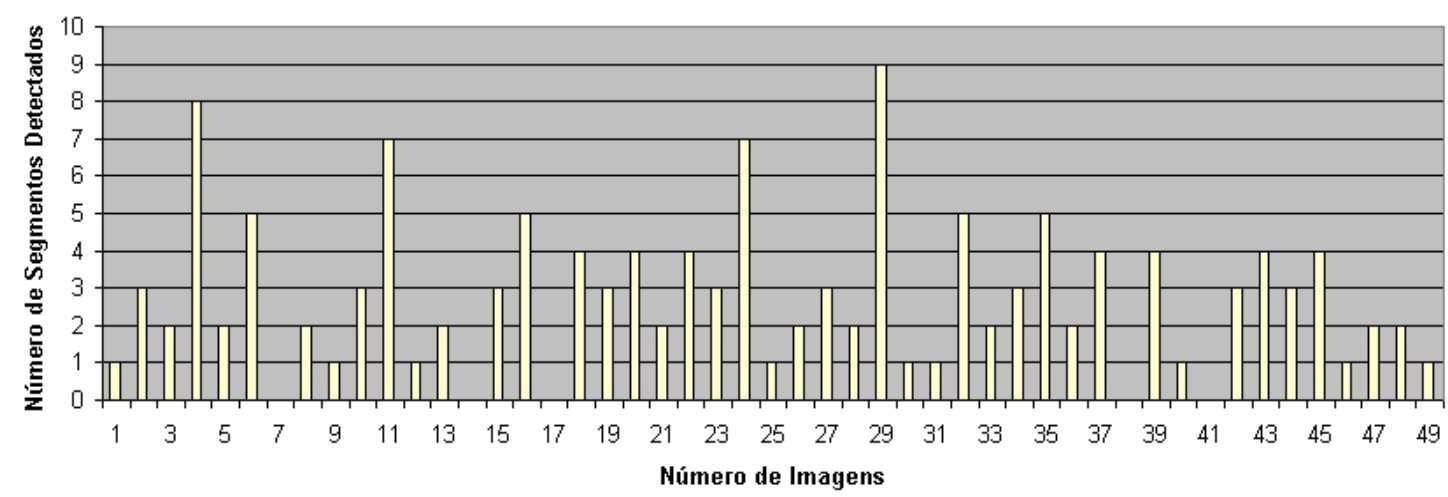

Figura C.3: Número de Segmentos Áureos Horizontais detectados nas faces 


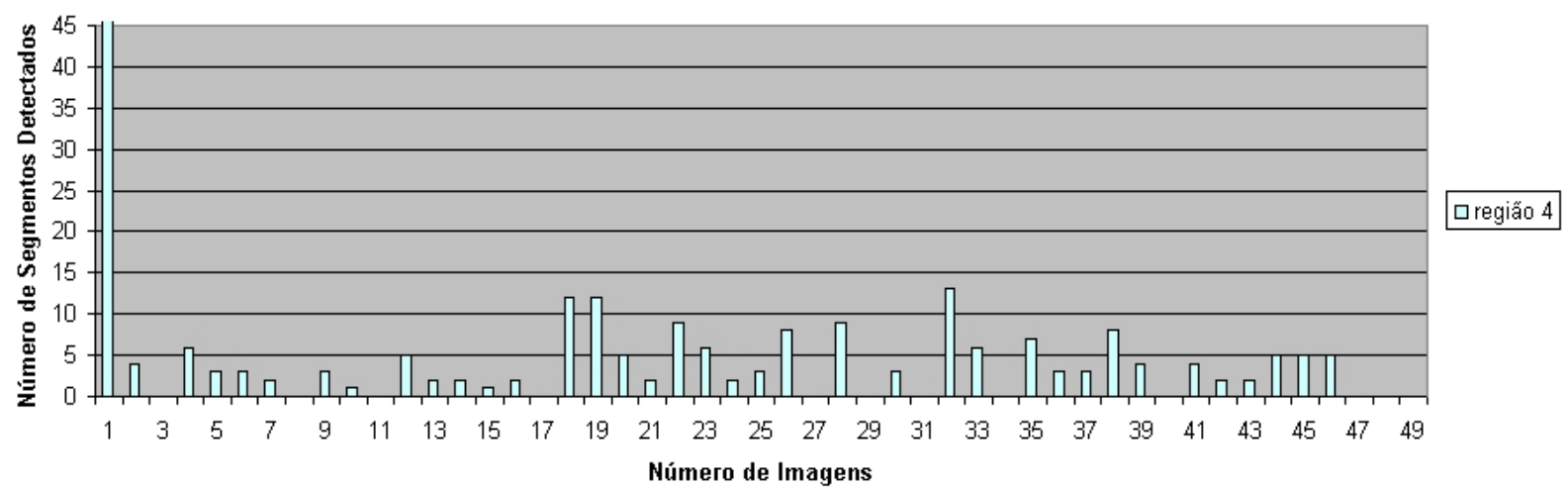

Figura C.4: Número de Segmentos Áureos Horizontais detectados nas faces

Nas Figuras C.5, C.6, C.7 e C.8 temos os gráficos com o número de segmentos áureos horizontais obtidos nas 51 faces femininas na região 1, 2, 3 e 4 da imagem.

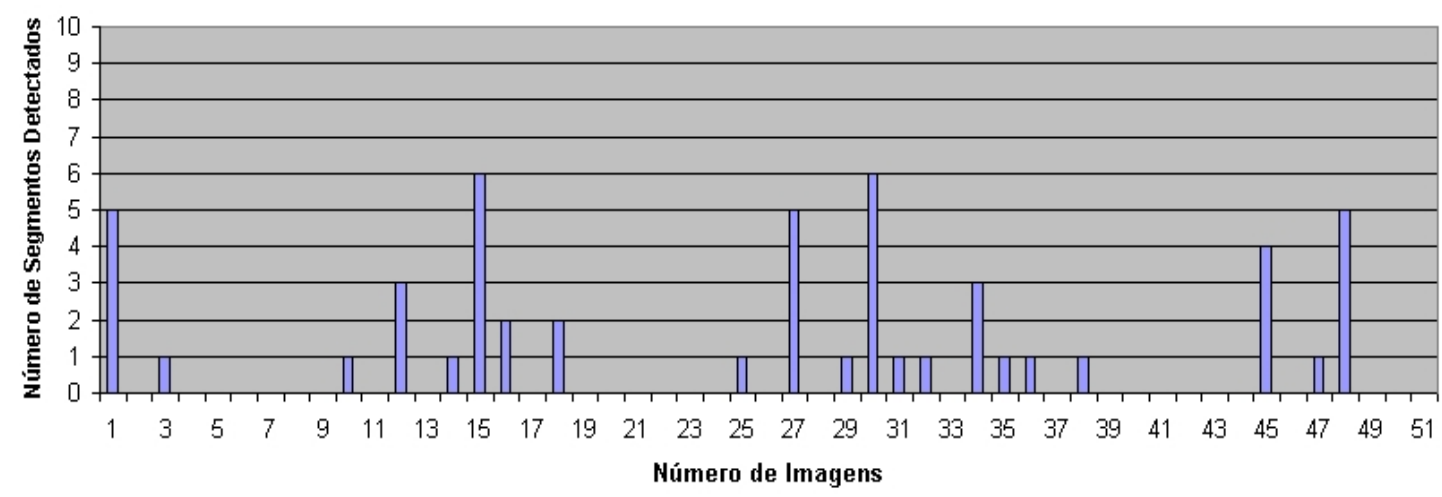

Figura C.5: Número de Segmentos Áureos Horizontais detectados nas faces

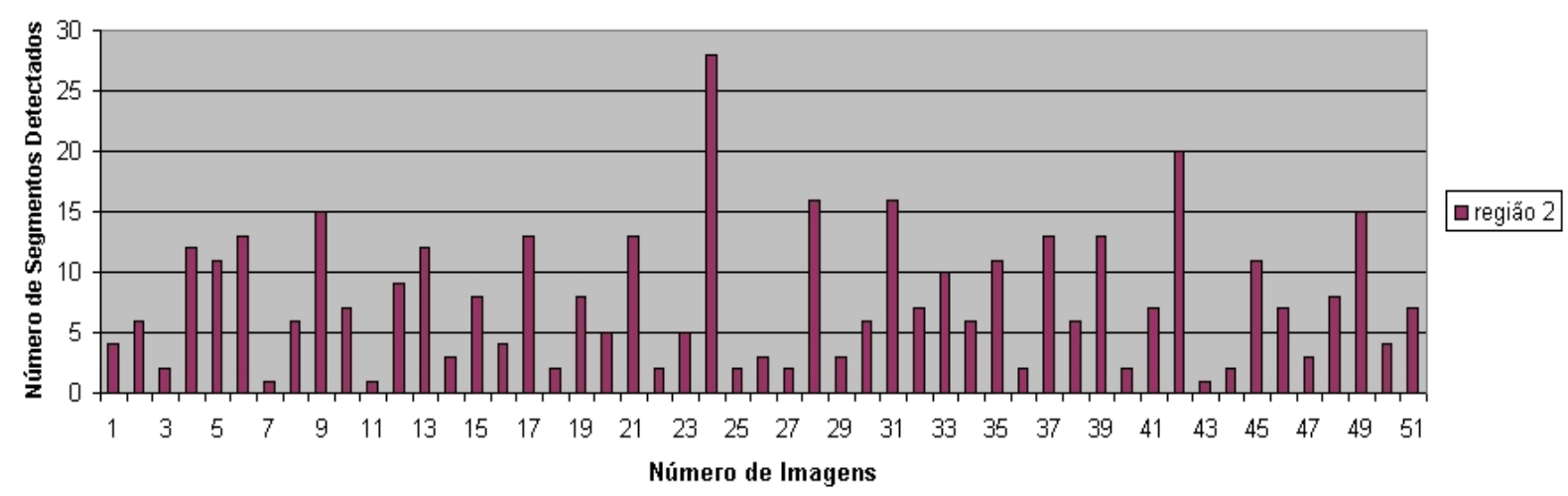

Figura C.6: Número de Segmentos Áureos Horizontais detectados nas faces 


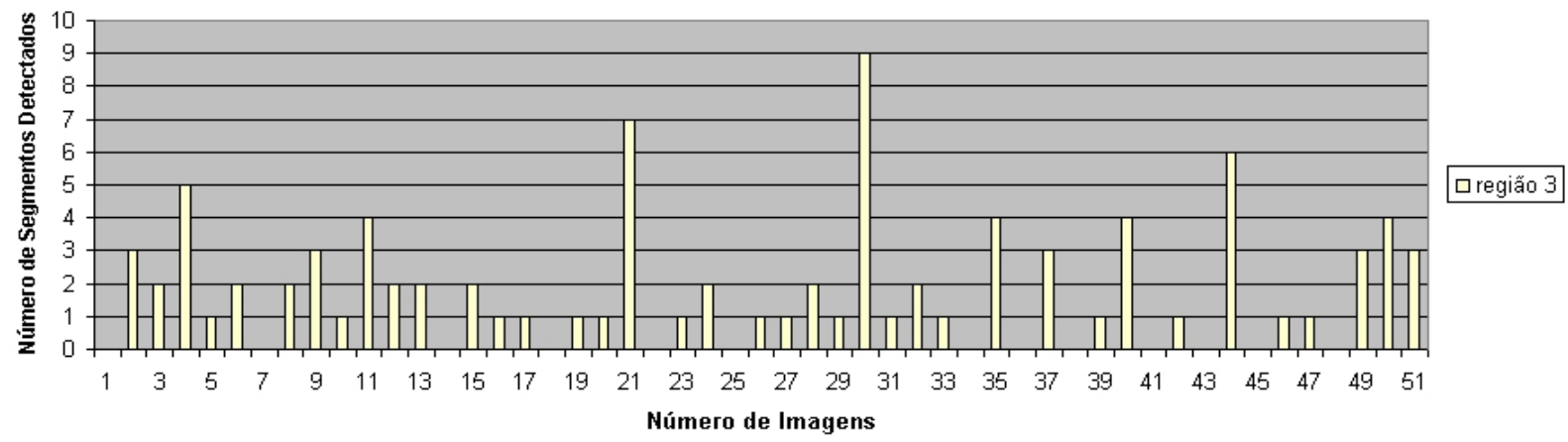

Figura C.7: Número de Segmentos Áureos Horizontais detectados nas faces

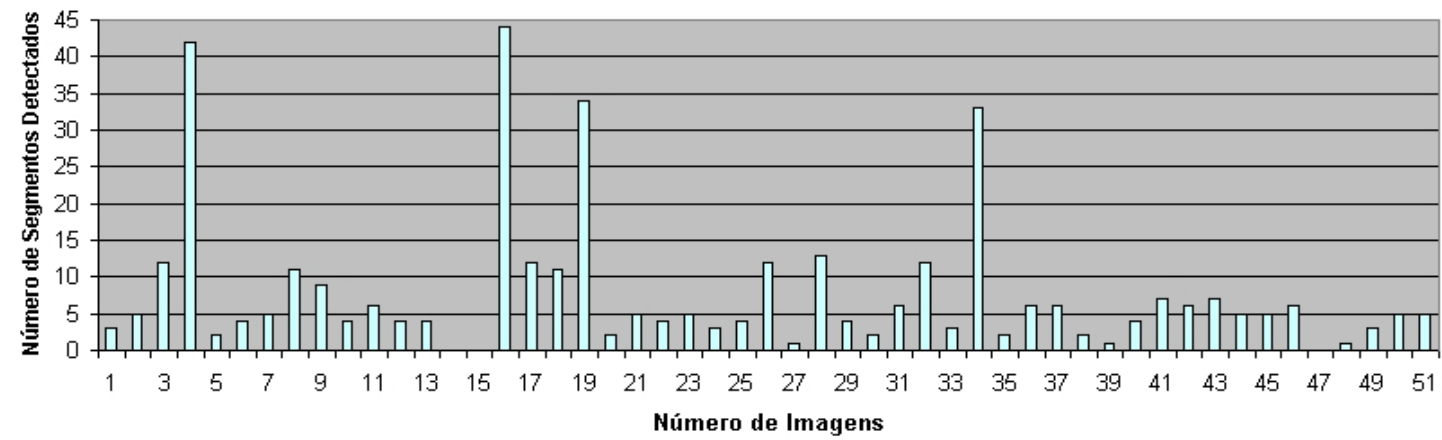

Figura C.8: Número de Segmentos Áureos Horizontais detectados nas faces

\section{C.2 Segmento Áureo Vertical}

As Figuras C.9, C.10, C.11 e C.12 mostram os gráficos com o número de segmentos áureos verticais obtidos nas 49 faces masculinas nas regiões 1, 2, 3, e 4 da imagem.

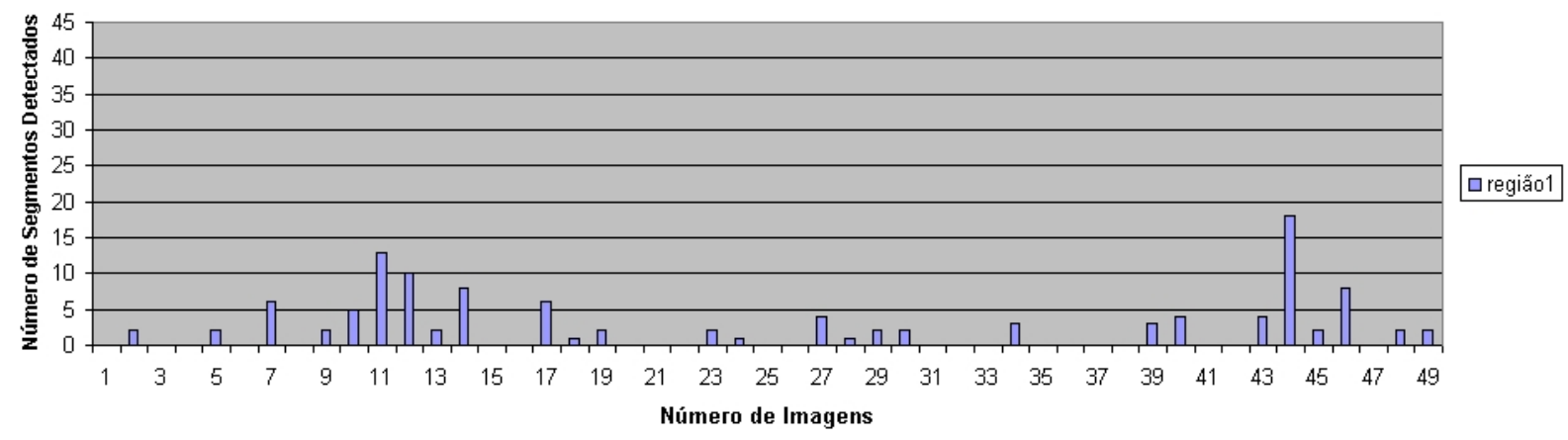

Figura C.9: Número de Segmentos Áureos Verticais detectados nas faces 


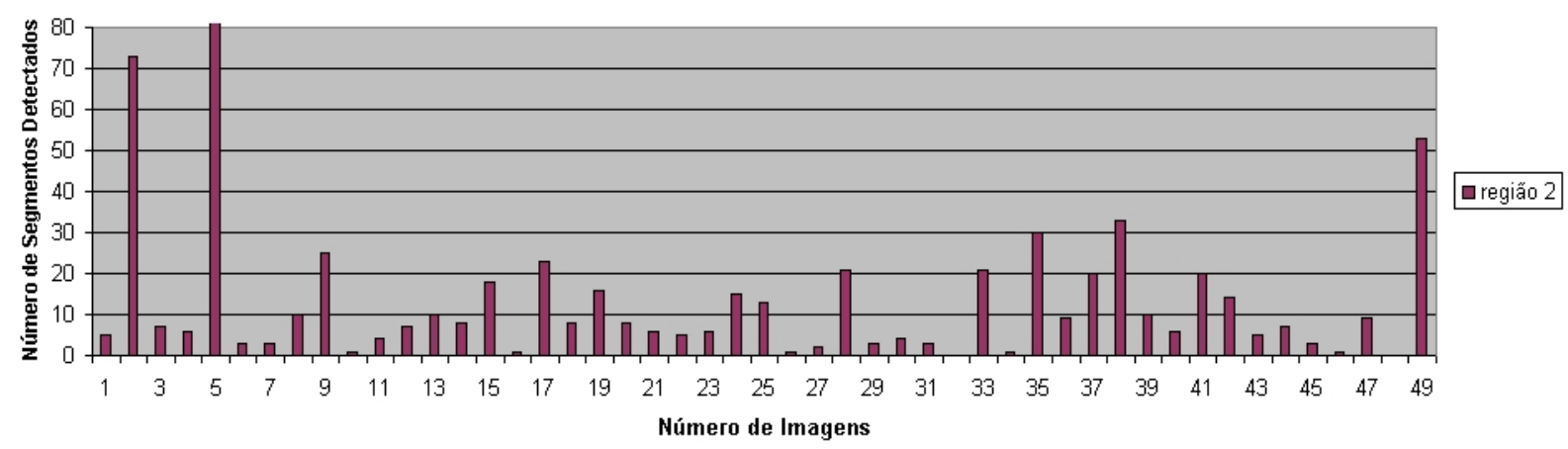

Figura C.10: Número de Segmentos Áureos Verticais detectados nas faces

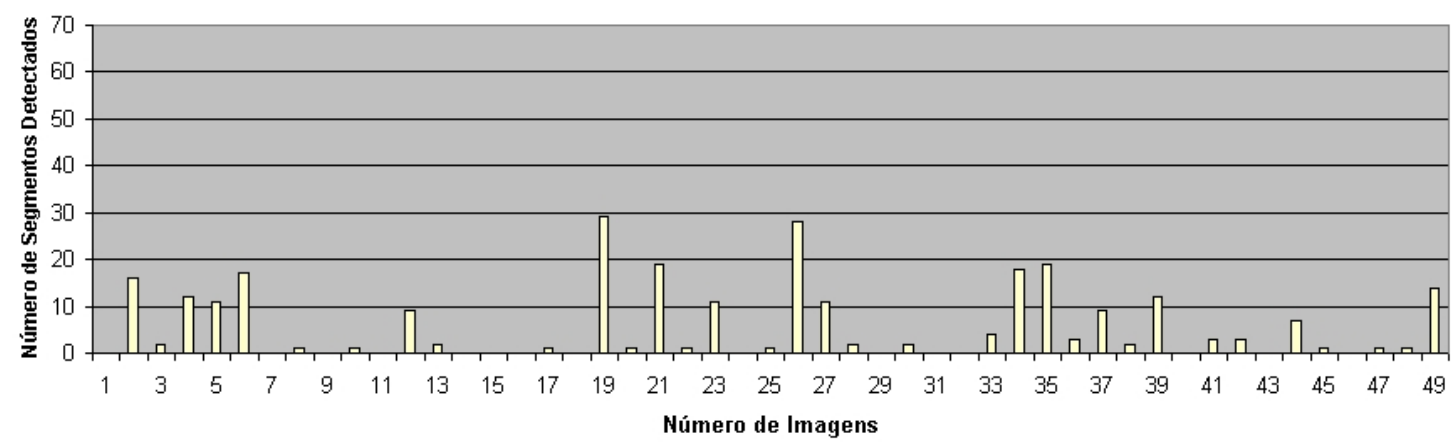

Figura C.11: Número de Segmentos Áureos Verticais detectados nas faces

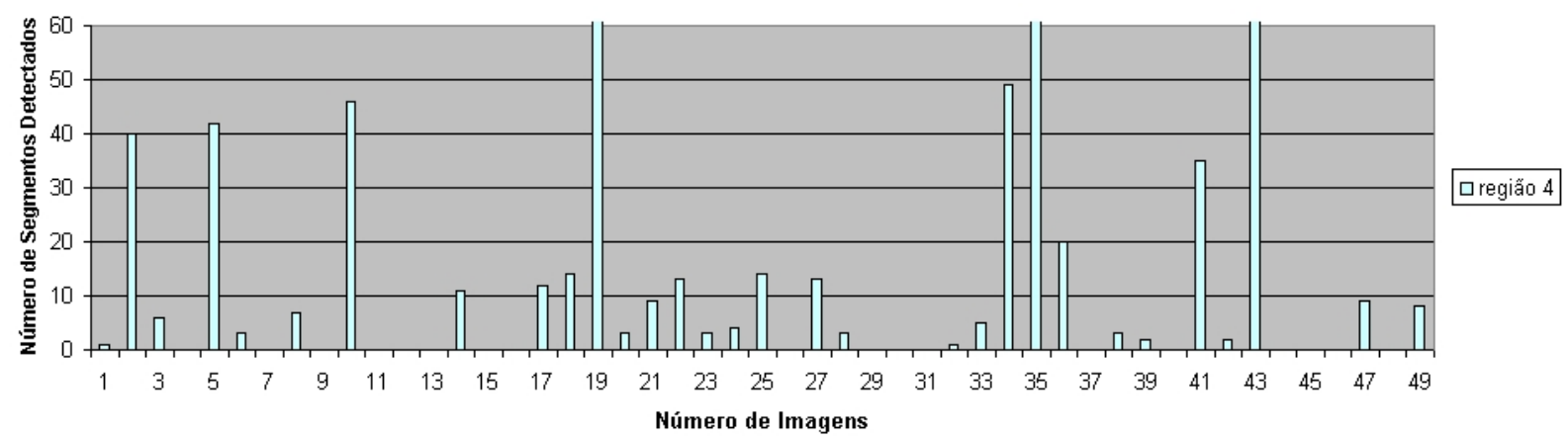

Figura C.12: Número de Segmentos Áureos Verticais detectados nas faces

Nas Figuras C.13, C.14, C.15 e C.16 tem-se os gráficos com o número de segmentos áureos verticais obtidos nas 51 faces femininas nas regiões 1, 2, 3 e 4 da imagem. 


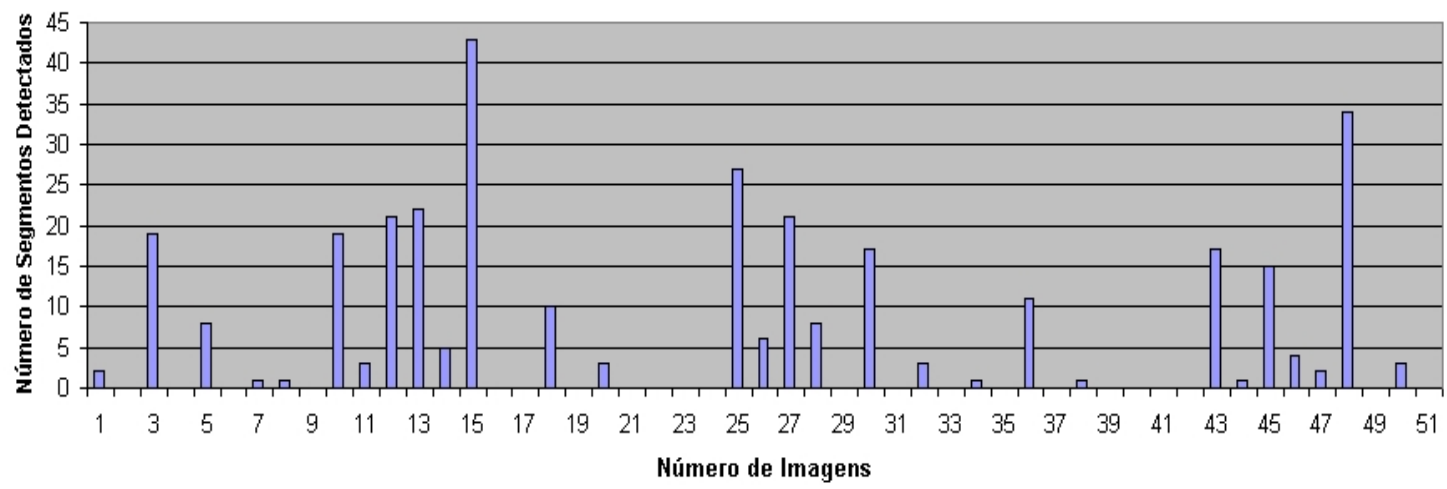

Figura C.13: Número de Segmentos Áureos Verticais detectados nas faces

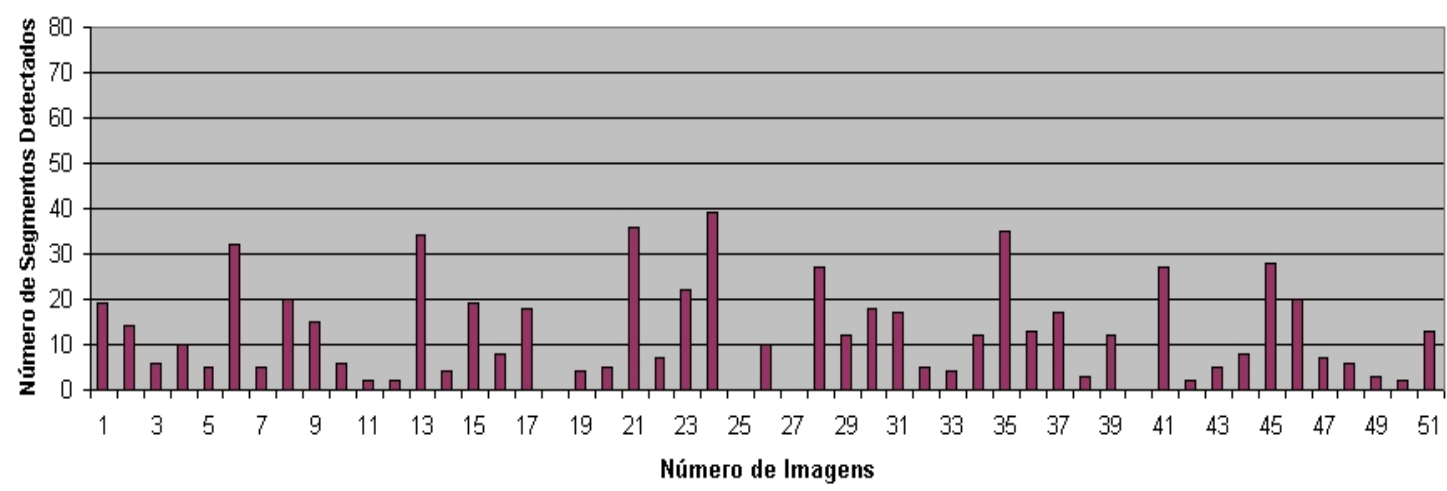

Figura C.14: Número de Segmentos Áureos Verticais detectados nas faces

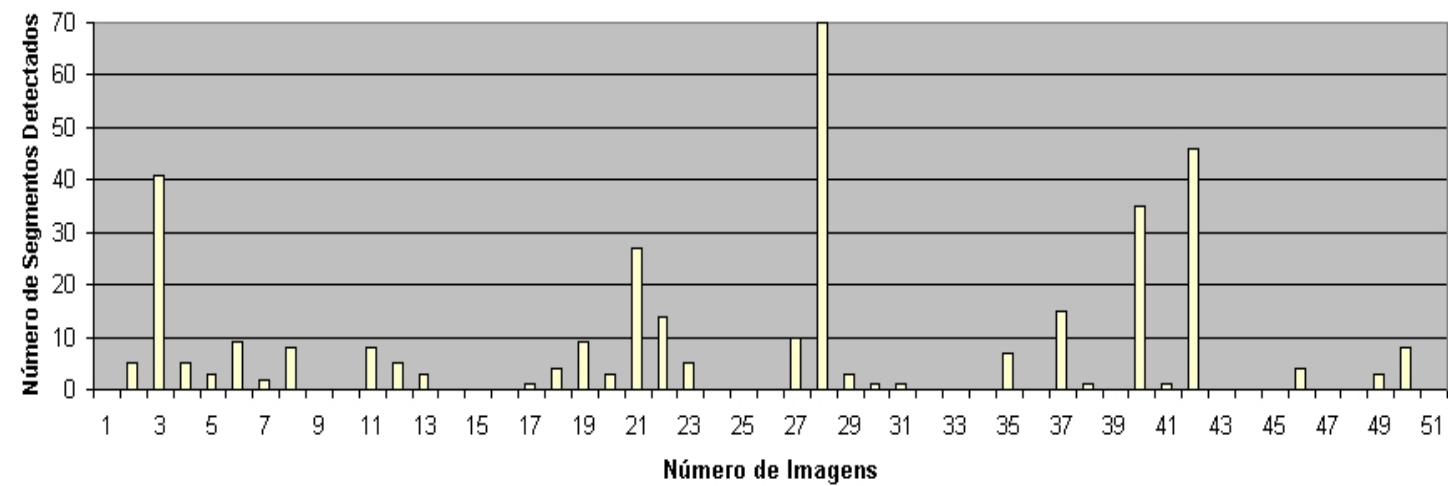

Figura C.15: Número de Segmentos Áureos Verticais detectados nas faces 


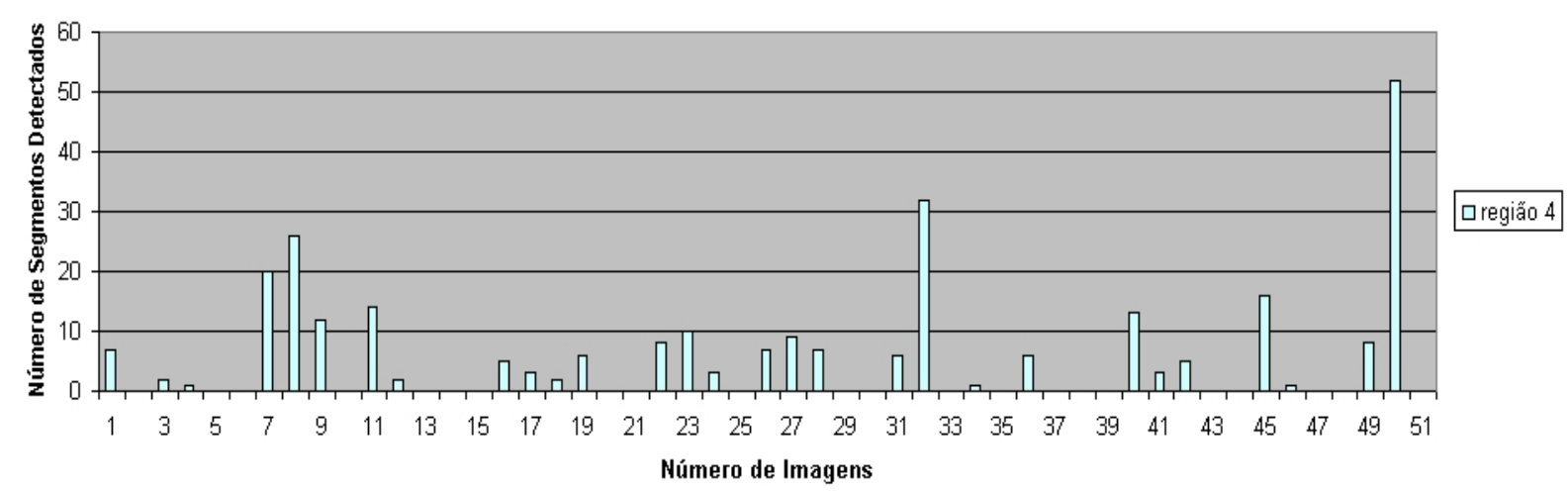

Figura C.16: Número de Segmentos Áureos Verticais detectados nas faces

\section{C.3 Retângulo Áureo Horizontal}

Os gráficos a seguir mostram o número de retângulos áureos horizontais detectados em cada uma das quatro regiões das imagens do banco de imagens de treinamento.

Nas Figuras C.17, C.18, C.19 e C.20 pode-se visualizar o número de retângulos áureos horizontais encontrados nas regiões 1, 2, 3 e 4 das 49 imagens de faces masculinas.

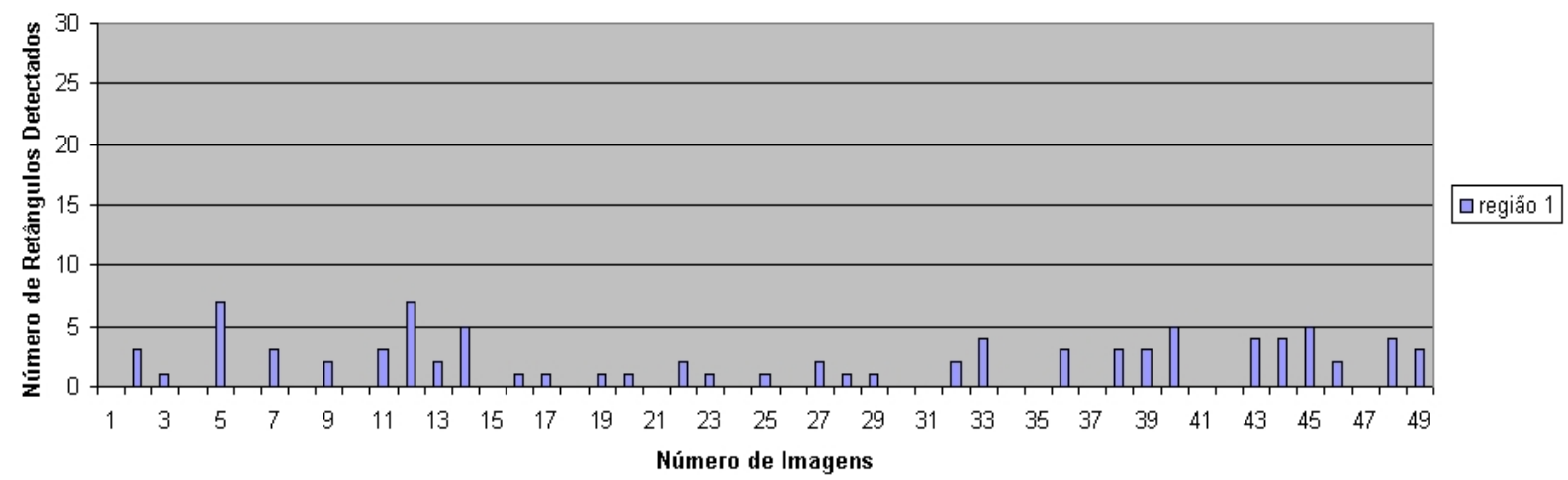

Figura C.17: Número de Retângulos Áureos Horizontais detectados nas faces 


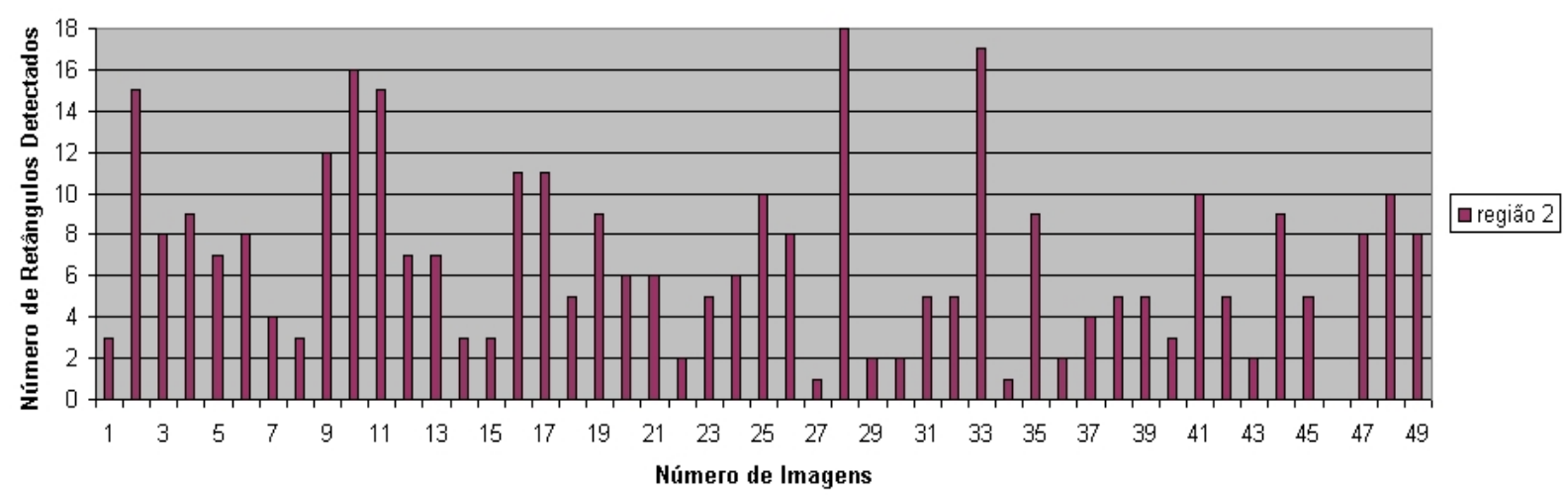

Figura C.18: Número de Retângulos Áureos Horizontais detectados nas faces

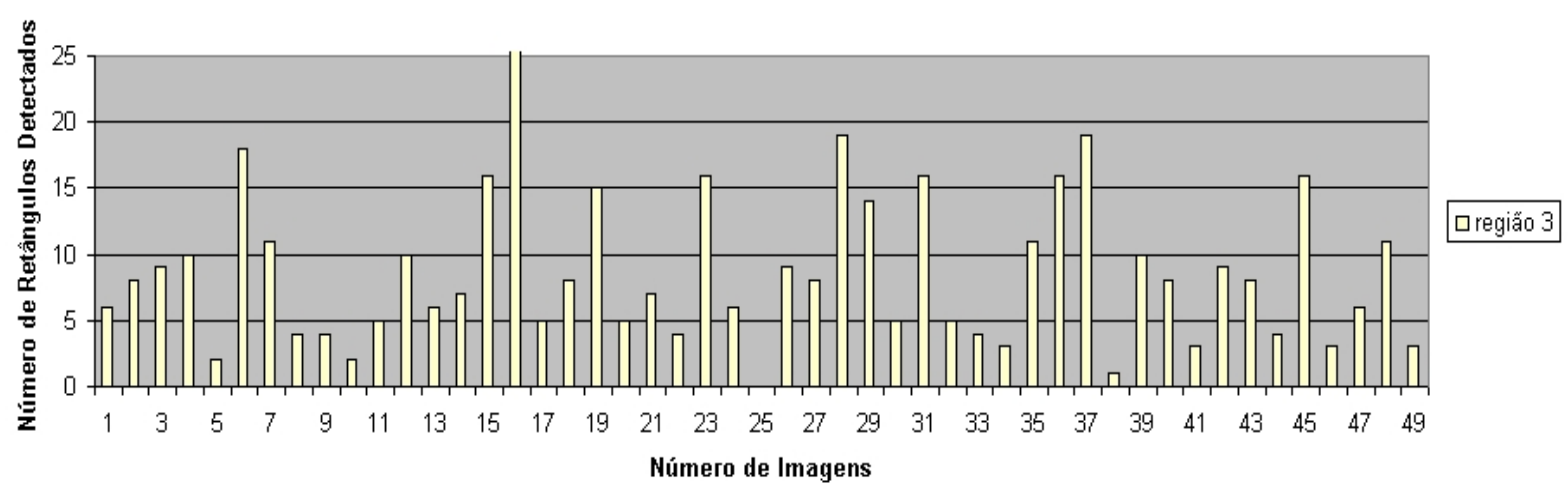

Figura C.19: Número de Retângulos Áureos Horizontais detectados nas faces

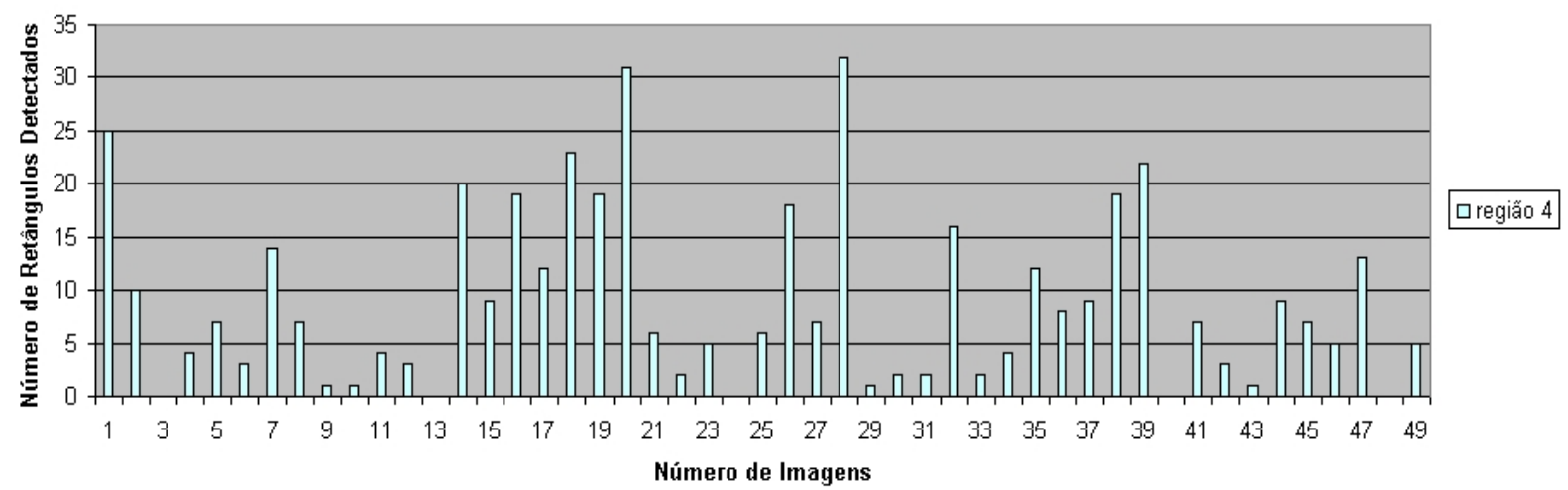

Figura C.20: Número de Retângulos Áureos Horizontais detectados nas faces

Os gráficos das Figuras C.21, C.22, C.23 e C.24 mostram os gráficos com os resultados da detecção do retângulo áureo horizontal nas regiões 1, 2, 3 e 4 das 51 imagens de faces femininas. 


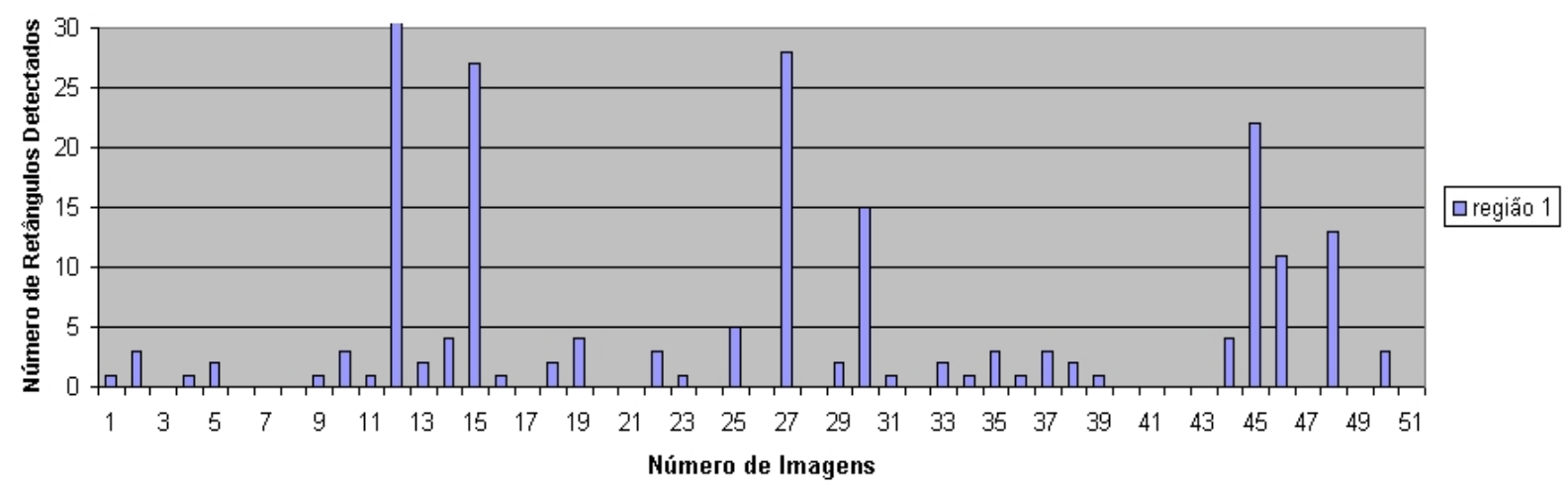

Figura C.21: Número de Retângulos Áureos Horizontais detectados nas faces

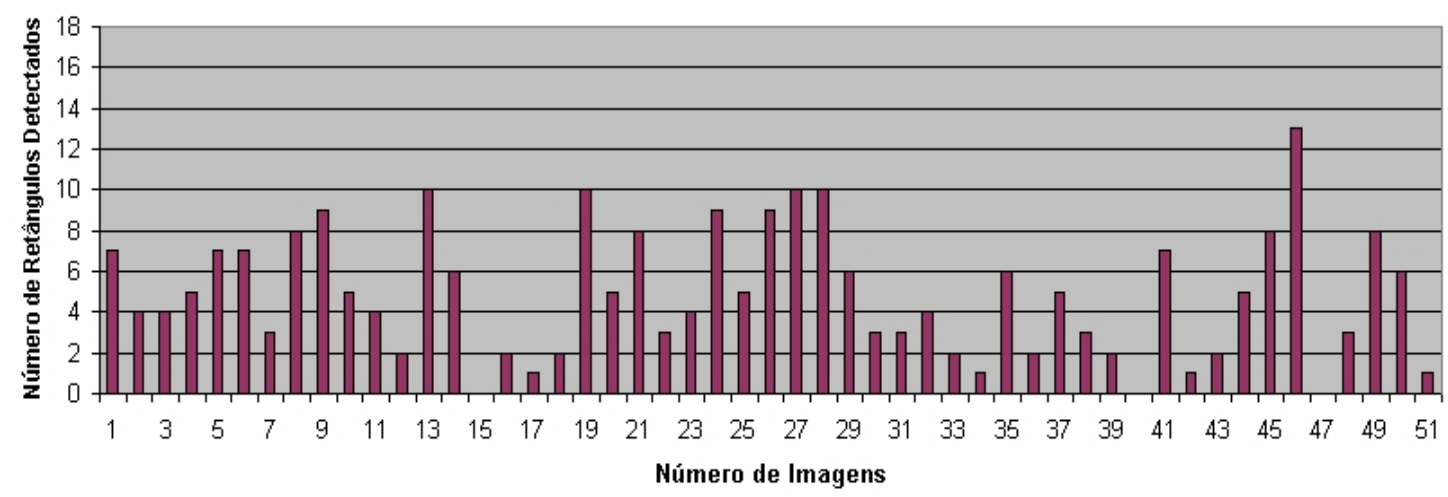

Figura C.22: Número de Retângulos Áureos Horizontais detectados nas faces

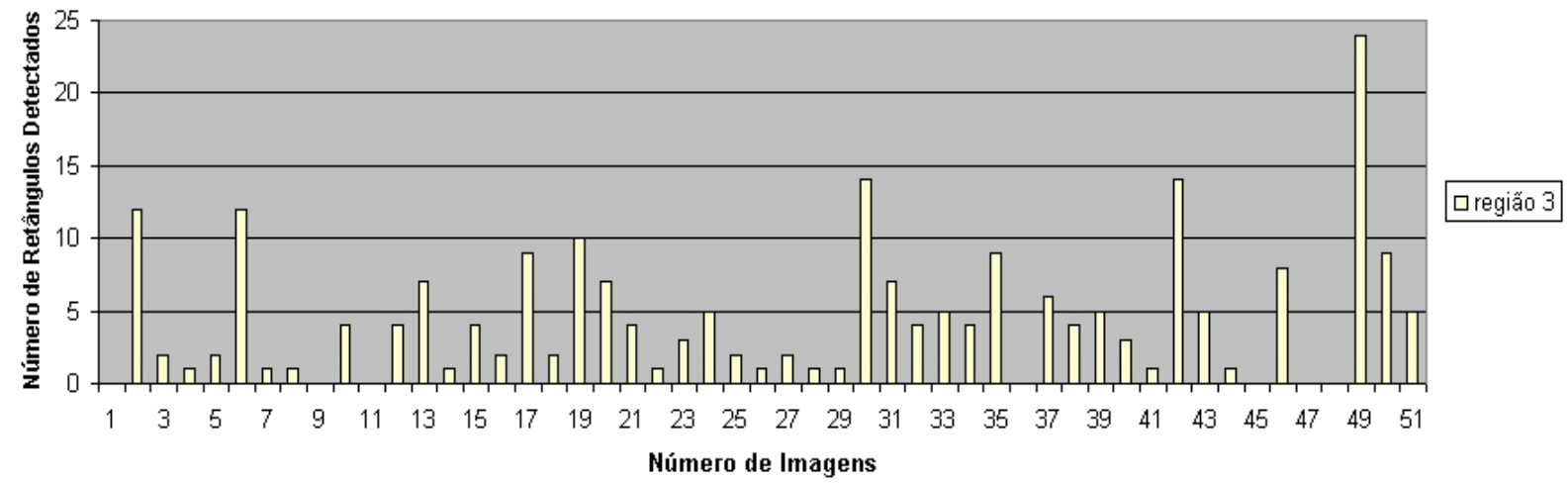

Figura C.23: Número de Retângulos Áureos Horizontais detectados nas faces 


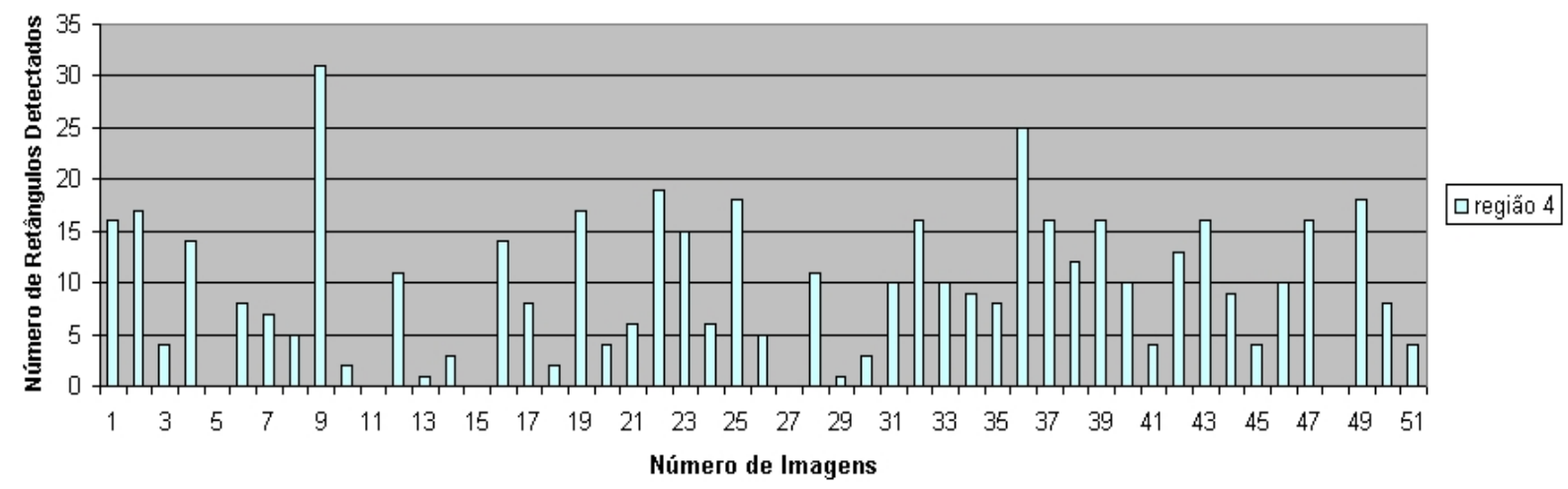

Figura C.24: Número de Retângulos Áureos Horizontais detectados nas faces

\section{C.4 Retângulo Áureo Vertical}

Os gráficos a seguir mostram o número de retângulos áureos verticais detectados em cada uma das quatro regiões da imagem.

Nas Figuras C.25, C.26, C.27, C.28 pode-se visualizar o número de retângulos áureos verticais encontrados nas regiões 1, 2, 3 e 4 das 49 imagens de faces masculinas.

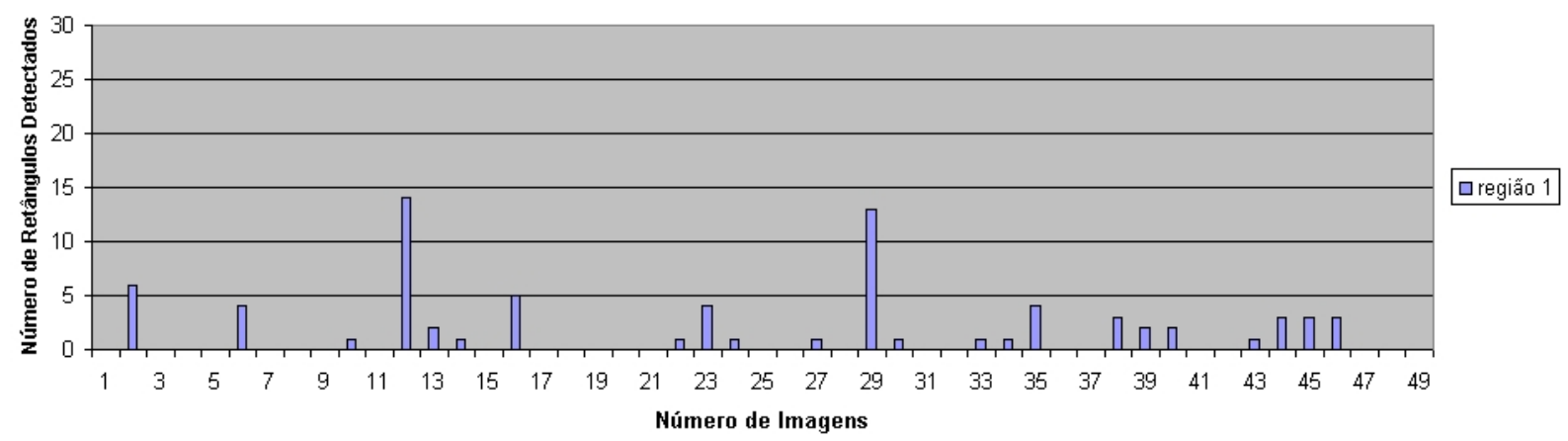

Figura C.25: Número de Retângulos Áureos Verticais detectados nas faces 


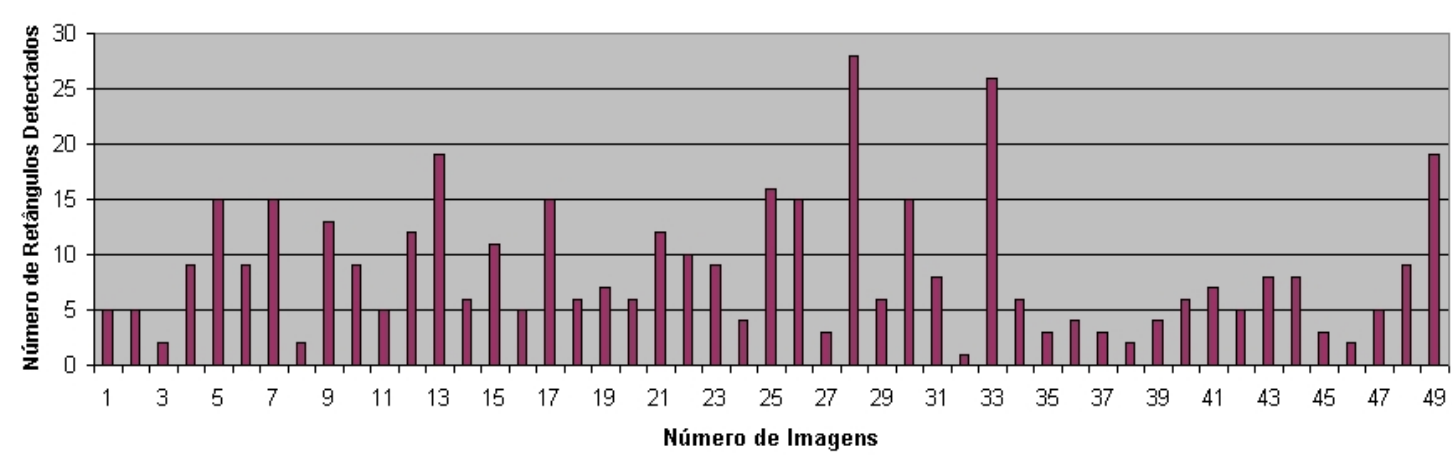

Figura C.26: Número de Retângulos Áureos Verticais detectados nas faces

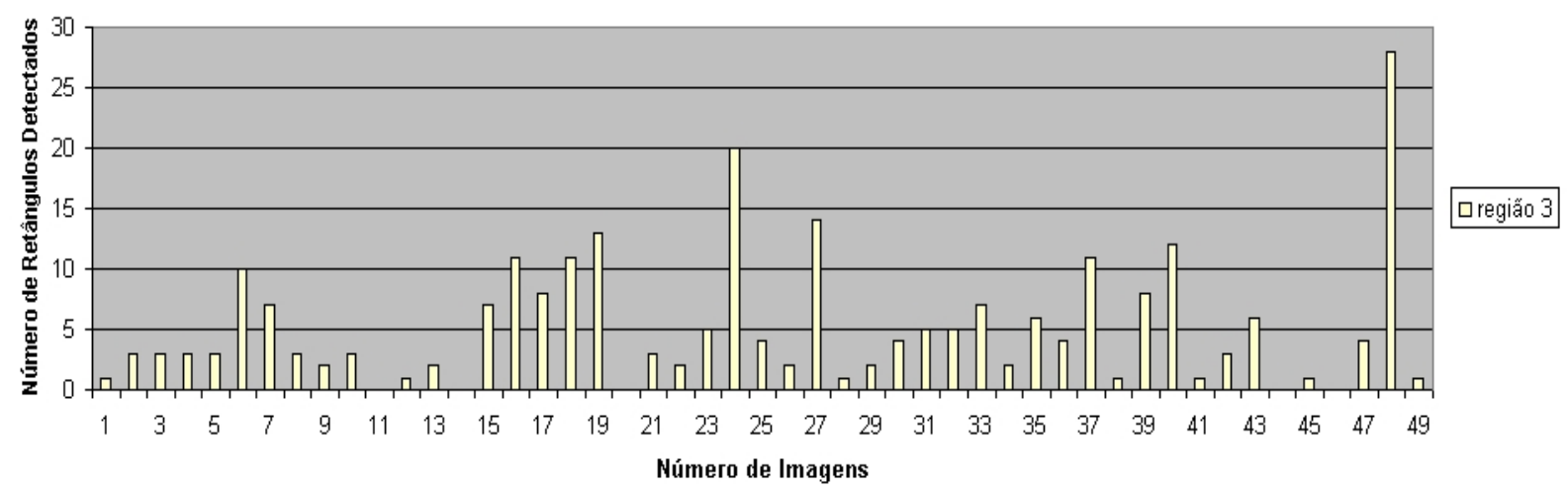

Figura C.27: Número de Retângulos Áureos Verticais detectados nas faces

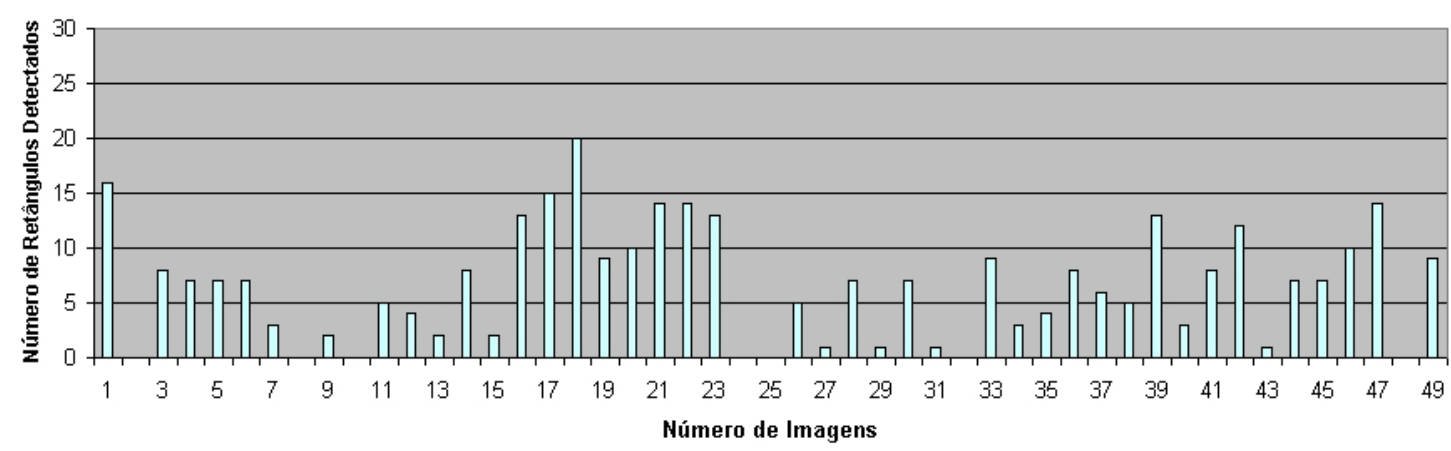

Figura C.28: Número de Retângulos Áureos Verticais detectados nas faces

Os gráficos das Figuras C.29, C.30, C.31 e C.32 mostram os resultados da detecção do retângulo áureo vertical nas regiões 1, 2, 3 e 4 das 51 imagens de faces femininas. 


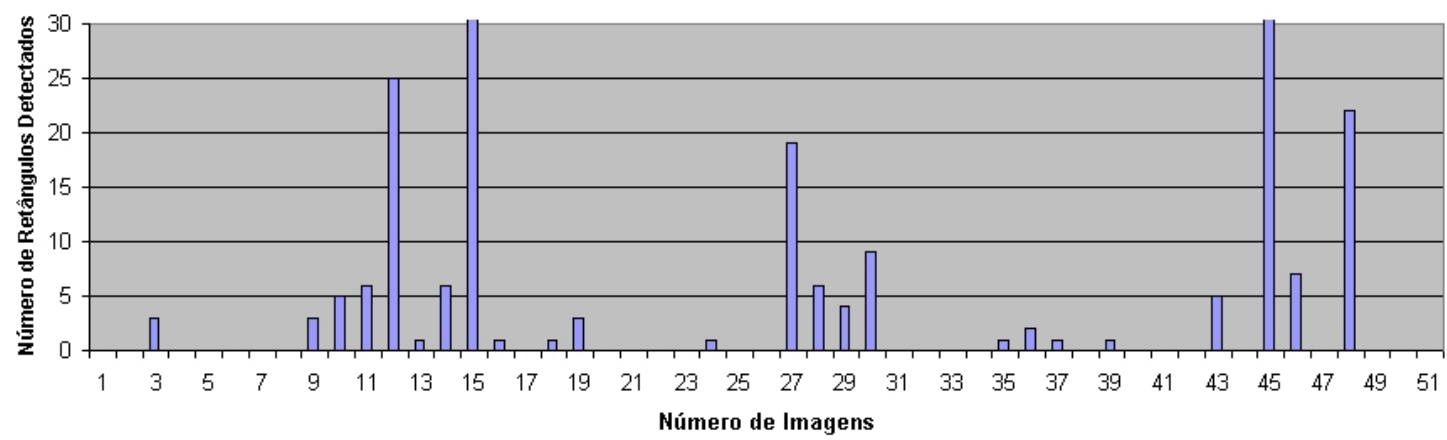

Figura C.29: Número de Retângulos Áureos Verticais detectados nas faces

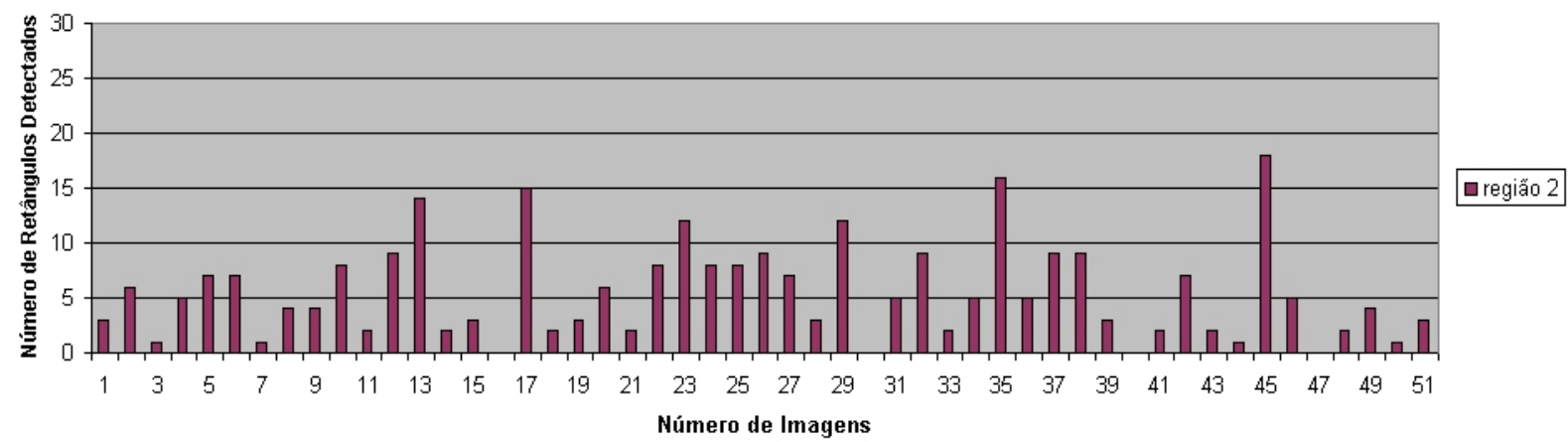

Figura C.30: Número de Retângulos Áureos Verticais detectados nas faces

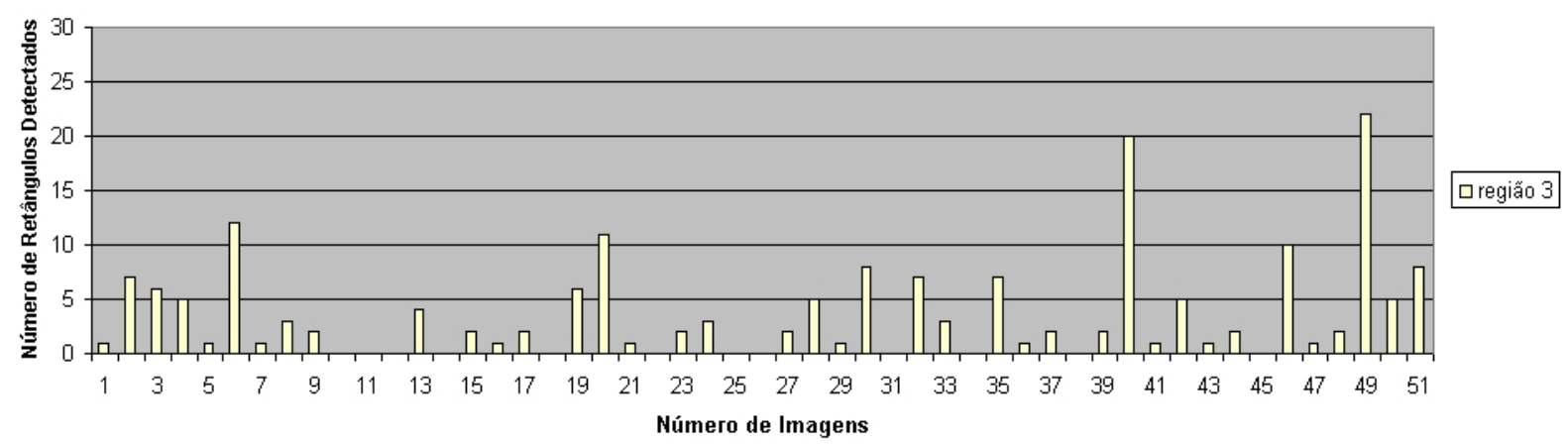

Figura C.31: Número de Retângulos Áureos Verticais detectados nas faces 


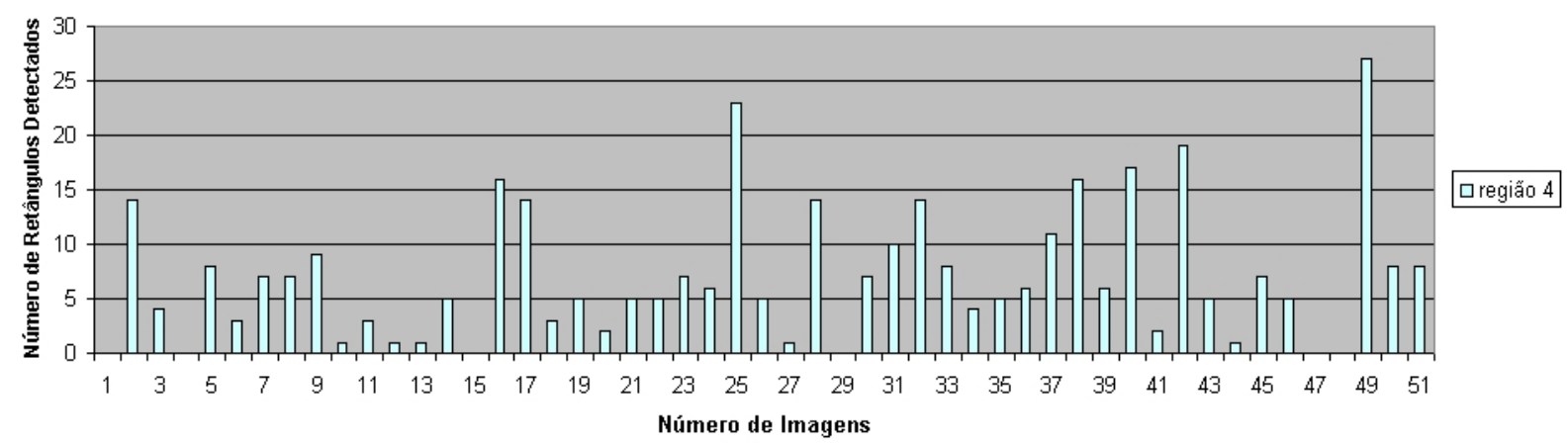

Figura C.32: Número de Retângulos Áureos Verticais detectados nas faces

Através dos gráficos obtidos definem-se as funções de pertinências dos sistemas "fuzzy" do segmento e retângulo áureo horizontal e vertical como explicitado no capítulo 4. 